DANIEL ADENSOHN DE SOUZA

\title{
A PROTEÇÃO JURÍDICA DO NOME DE EMPRESA NO BRASIL
}

Dissertação apresentada à Faculdade de Direito da Universidade de São Paulo para obtenção do título de Mestre em Direito Comercial, sob orientação do Professor Doutor Newton Silveira

Faculdade de Direito da Universidade de São Paulo

Departamento de Direito Comercial

São Paulo 
FOLHA DE APROVAÇÃO:

Professor Orientador: Prof. ${ }^{\circ}$ Dr. Newton Silveira 


\section{Agradecimentos}

Agradeço ao Prof. ${ }^{\circ}$ Newton Silveira, que não só me brindou com sua orientação, mas me deu a oportunidade de assisti-lo em suas aulas de Direito Comercial na graduação, cujo convívio amiúde e interação com os alunos muito me ensinaram. Agradeço, também, aos colegas de trabalho, pelo apoio e salutares discussões, assim como a todos aqueles que, de alguma forma, contribuíram para a realização deste trabalho. 
Dedico este trabalho à minha família, pelo constante estímulo e apoio, e à minha Maristela, pelo incondicional e indissolúvel amor, incentivo e compreensão. 


\section{SUMÁRIO}

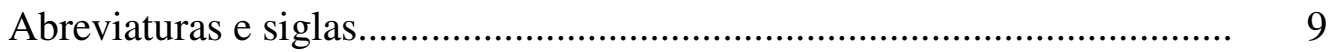

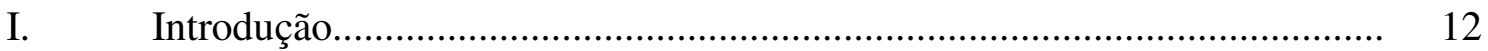

\section{Capítulo I}

\section{O DIREITO À IDENTIDADE}



2. $\quad$ A identificação das pessoas.................................................................. 18

3. O direito/dever ao nome.................................................................... 20

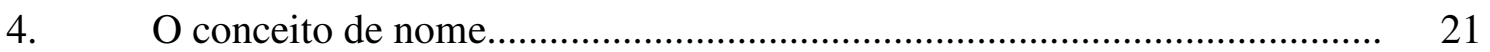

5. O nome no plano pessoal............................................................... 22

6. O nome no plano empresarial.......................................................... 23

7. As distintas funções exercidas pelo nome................................................. 24

8. Diferenças entre o nome civil e o nome de empresa.................................. 25

\section{Capítulo II \\ O NOME DE EMPRESA}

1. Os sinais distintivos do empresário..................................................... 27

2. $\quad$ A questão da nomenclatura...................................................................... 29

2.1. Nome comercial.................................................................................. 29

2.2. Nome de empresa.......................................................................... 31

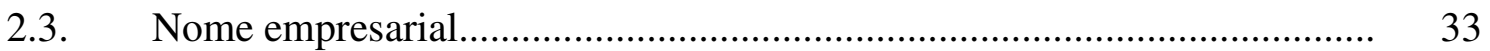

3. Conceito do nome empresarial........................................................... 35

4. Modalidades de nome empresarial........................................................ 39

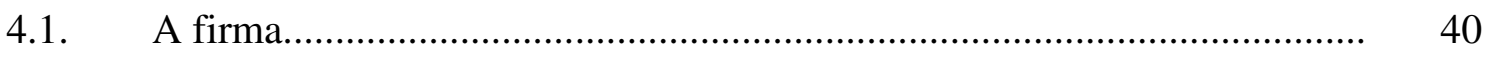

4.1.1. Firma individual............................................................................... 41

4.1.2. Firma ou razão social................................................................................. 41

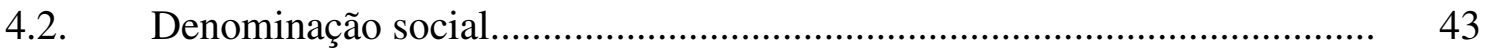

5. Princípios gerais aplicados às firmas e denominações............................... 44 
5.1. Princípio da veracidade..................................................................... 44

5.2. Princípio da novidade........................................................................... 44

6. A dupla função do nome empresarial...................................................... 45

7. Natureza jurídica do nome empresarial................................................... 48

7.1. O nome empresarial como direito da personalidade................................. 49

7.2. $\quad$ O nome empresarial como direito de propriedade..................................... 50

7.3. O nome empresarial como direito pessoal (ou obrigacional)..................... 52

8. A adoção do patronímico como nome comercial........................................ 55

8.1. A questão dos homônimos.................................................................. 57

9. A inalienabilidade do nome empresarial............................................... 59

9.1. Nome empresarial derivado............................................................ 60

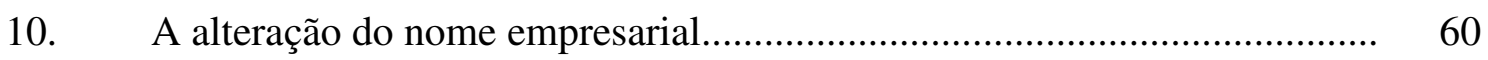

11. A extinção do nome empresarial.............................................................. 61

\section{Capítulo III}

O NOME DO EMPRESÁRIO E DAS SOCIEDADES EM ESPÉCIE

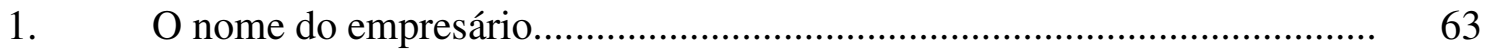

2. Sociedades não personificadas........................................................... 64

2.1. Sociedade em comum......................................................................... 64

2.2. Sociedade em conta de participação.......................................................... 64

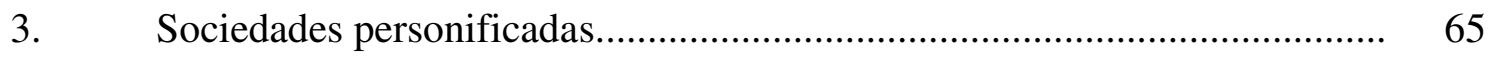

3.1. Sociedades Simples........................................................................... 65

3.2. Sociedade em nome coletivo................................................................... 65

3.3. Sociedade em comandita simples........................................................... 66

3.4. Sociedade limitada.......................................................................... 66

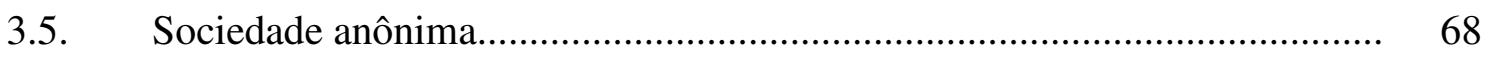

3.6. Sociedade em comandita por ações......................................................... 69

4. Grupos societários........................................................................ 70

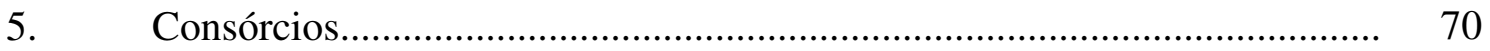

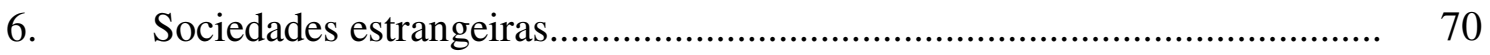

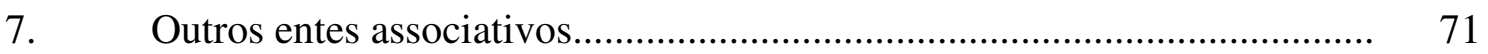

7.1. Sociedade cooperativa.................................................................... 71 
7.2. Sociedade de advogados................................................................ 72

7.3. Partidos políticos................................................................................ $\quad 74$

8. A questão do nome dos condomínios edilícios........................................ 74

9. Outras regras de formação do nome....................................................... 75

9.1. As empresas de pequeno porte e as microempresas................................. 75

9.2. O empresário em recuperação judicial........................................................ 76

9.3. As instituições financeiras em liquidação................................................... 76

\section{Capítulo IV}

\section{A PROTEÇÃO INTERNACIONAL DO NOME DE EMPRESA}

1. O nome empresarial no orbe internacional............................................ 78

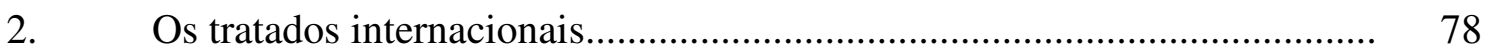

2.1. A Convenção da União de Paris............................................................... 78

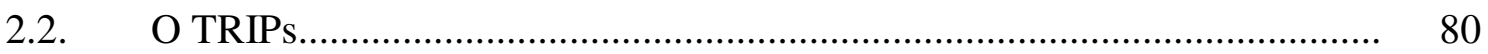

3. O nome comercial no Mercosul............................................................. 81

4. O nome comercial no NAFTA........................................................... 82

\section{Capítulo V}

\section{A TUTELA DO NOME DE EMPRESA NO BRASIL}

1. $\quad$ Evolução legislativa da proteção do nome empresarial no Brasil................ 83

2. Legislação em vigor aplicável ao nome de empresa no Brasil................... 88

3. O nascimento da proteção.................................................................... 94

4. O conflito entre nomes empresariais....................................................... 96

4.1. Os critérios de colidência entre as firmas e razões sociais........................... 96

4.2. Os critérios de colidência entre denominações sociais............................... 98

4.3. Os critérios de colidência entre denominações e firmas............................... 100

4.4. A questão das siglas............................................................................... 101

5. O âmbito e a extensão da proteção ao nome empresarial............................. 102

6. Medidas administrativas........................................................................ 111

6.1. O recurso ao plenário da Junta Comercial................................................ 111 
6.2. A jurisprudência do DNRC ..................................................................... 112

6.3. A extensão da proteção às outras Juntas Comerciais................................... 114

7. Medidas judiciais no âmbito civil.......................................................... 116

7.1. Generalidades......................................................................... 116

7.2. Ação de abstenção de uso..................................................................... 118

7.3. Ação anulatória de inscrição do nome empresarial..................................... 119

Ação indenizatória.............................................................................. 120

7.5. A prescrição das ações envolvendo o nome empresarial............................ 123

7.5.1. A prescrição das ações de abstenção de uso............................................... 123

7.5.2. A prescrição das ações de modificação...................................................... 124

7.5.3. A prescrição das ações indenizatórias...................................................... 125

8. Medidas judiciais no âmbito criminal..................................................... 125

9. O conflito entre nome empresarial e outros sinais distintivos.................... 126

9.1. Nome empresarial $v s$ marca................................................................... 127

9.2. Nome empresarial $v s$ título de estabelecimento.......................................... 129

9.3 Nome empresarial $v s$ nome de domínio................................................. 130

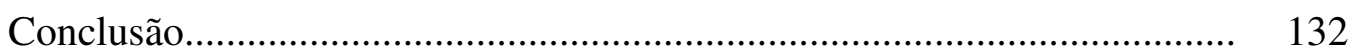

Apêndice legislativo............................................................................. 136

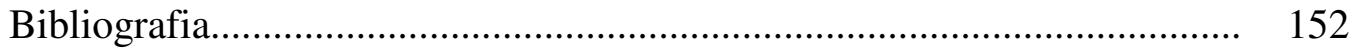

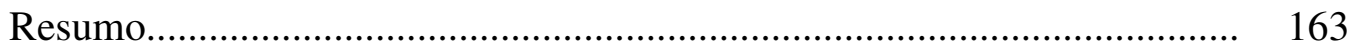

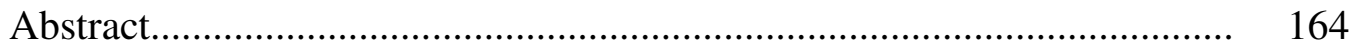




\section{ABREVIATURAS E SIGLAS}

\begin{tabular}{|c|c|}
\hline ABPI & Associação Brasileira da Propriedade Intelectual \\
\hline $\mathrm{AC}$ & Apelação Cível \\
\hline ADPIC & $\begin{array}{l}\text { Acordo sobre Aspectos dos Direitos de Propriedade Intelectual } \\
\text { relacionados ao Comércio }\end{array}$ \\
\hline AI & Agravo de instrumento \\
\hline ampl. & Ampliada \\
\hline $\mathrm{AgRg}$ & Agravo Regimental \\
\hline art. & Artigo \\
\hline Bacen & Banco Central do Brasil \\
\hline Câm. & Câmara \\
\hline Cap. & Capítulo \\
\hline $\mathrm{CC}$ & Código Civil \\
\hline C.Com. & Código Comercial \\
\hline CDC & Código de Defesa do Consumidor \\
\hline Cf. & Conforme \\
\hline $\mathrm{CF}$ & Constituição Federal da República Federativa do Brasil (de 05/10/1988) \\
\hline cit. & citado \\
\hline $\mathrm{CMN}$ & Conselho Monetário Nacional \\
\hline Coord. & Coordenador \\
\hline $\mathrm{CPC}$ & Código de Processo Civil \\
\hline CUP & Convenção da União de Paris para Proteção da Propriedade Industrial \\
\hline Des. & Desembargador \\
\hline DJ & Diário de Justiça \\
\hline DL & Decreto-Lei \\
\hline DNRC & Departamento Nacional do Registro do Comércio \\
\hline DOU & Diário Oficial da União \\
\hline ed. & edição \\
\hline EDcl & Embargos de Declaração \\
\hline e.g. & exempli gratia (por exemplo) \\
\hline EDcl & Embargos de Declaração \\
\hline FADUSP & Faculdade de Direito da Universidade de São Paulo \\
\hline
\end{tabular}


GATT General Agreement on Tariffs and Trade (ou Acordo Geral sobre Tarifas e Comércio)

et. al. et alii (e outros)

i.e. id est (isto é)

inc. inciso

IN Instrução Normativa

INPI Instituto Nacional da Propriedade Industrial

j. $\quad$ julgado em

LPI Lei da Propriedade Industrial (Lei ${ }^{\circ}$ 9.279, de 14 de maio de 1.996)

Mercosul Mercado Comum do Sul

Min. Ministro

NAFTA Tratado de Livre Comércio da América do Norte

OMC Organização Mundial do Comércio

OMPI Organização Mundial da Propriedade Intelectual (v. WIPO)

op. cit. opere citatum (citado acima)

p. página

p.ex. por exemplo

RDM Revista de Direito Mercantil, Industrial, Econômico e Financeiro

RE Recurso Extraordinário

Rel. Relator

REsp Recurso Especial

RT Revista dos Tribunais

rev. revista/revisto

ss. e seguintes

STF Supremo Tribunal Federal

STJ Superior Tribunal de Justiça

T. Turma

t. tomo

TFR Tribunal Federal de Recursos

Tit. Título

TJDF Tribunal de Justiça do Distrito Federal

TJRJ Tribunal de Justiça do Rio de Janeiro

TJSP Tribunal de Justiça do Estado de São Paulo 
trad. tradução/traduzido

TRF Tribunal Regional Federal

TRIPs Trade-Related to Intelectual Property Rights

v. vide, ver

v.g. verbi gratia

vol. volume

v.s versus

WIPO World Intellectual Property Organization (v.OMPI) 


\section{INTRODUÇÃO}

\section{Relevância do tema}

O nome comercial, nome de empresa ou nome empresarial ${ }^{1-2}$ é um dos mais vetustos institutos do direito de propriedade industrial ${ }^{3}$, remontando à origem do tráfico de mercadorias. Constitui sinal distintivo do empresário, identificando-o como sujeito de direitos e obrigações, podendo, ainda, distingui-lo de seus concorrentes caso seja usado no exercício de sua atividade econômica.

Trata-se o nome de empresa de bem imaterial, sendo um dos sinais distintivos de maior relevância e valor para o seu titular, objeto de um direito, a rigor, absoluto de utilização, cuja proteção encontra-se sob o pálio das normas que disciplinam o registro do comércio e a propriedade industrial.

Todavia, a proteção ao nome de empresa é problema crônico no Brasil, sendo, desde o século XIX, objeto de intensos e insolúveis debates. Muito se discutiu quanto à natureza, função, extensão e âmbito territorial de proteção ao nome comercial, especialmente no tocante ao conflito com nomes empresariais idênticos ou similares ${ }^{4}$, ou ainda, com outros sinais distintivos (como marcas, insígnias e títulos de estabelecimento).

\footnotetext{
${ }^{1}$ Embora nesta introdução usemos as expressões como sinônimas, veremos ao longo deste trabalho, a expressão nome de empresa ou nome empresarial, abraçada pelo Código Civil (Lei n 10.406/2002), foi cunhada em razão da adoção da teoria da empresa, no lugar da teoria dos atos de comércio oriunda do Code Napoléon de 1807 e que permeou o conceito de mercancia adotado pela Lei $\mathrm{n}^{\circ} 556$, de 25 de junho de 1850 , que instituiu o Código Comercial Brasileiro e pelo Regulamento 737, de 25 de novembro de 1850.

Constataremos que a substituição da expressão nome comercial por nome empresarial representa muito mais que mera alteração adjetiva, traduzindo-se em um verdadeiro alargamento significância e incidência. É dizer, nome empresarial não é mero sinônimo de nome comercial.

${ }^{2}$ Vale dizer, igualmente, que nossa legislação já vinha paulatinamente substituindo a vetusta expressão nome comercial, como se pode observar, p.ex. no Código da Propriedade Industrial de 1967 (Decreto-Lei n 254, de 28 de fevereiro de 1967) que se refere ao nome de empresa; na Constitução Federal de 1988 que alude ao nome de empresa; na Lei de Registro Público de Empresas Mercantis (Lei n ${ }^{\circ} 8.934$, de 18 de novembro de 1994) que expressamente refere-se ao "nome empresarial"; o Código Civil (Lei no 10.406, de 10 de janeiro de 2002) e, também na Lei de Falência e Recuperação de Empresas (Lei no 11.101, de 05 de fevereiro de 2005) em cujo art. 69 há referência ao "nome empresarial".

${ }^{3}$ ASCARELLI salienta que " $[d]$ espués del rótulo (no vernáculo: título de estabelecimento), el nombre comercial es el más antiguo de los signos distintivos, ya que una consideración competitiva entre los empresarios (y los locales de ejercicio) se ha planteado con anterioridad a la que corresponde a los productos. Se trata de un instituto que se remonta al período estatutário de la historia del Derecho mercantil" (in Teoría de la concurrencia y de los bienes inmateriales. Barcelona: Bosch, 1970, p. 359/360)

${ }^{4}$ Já dizia ROBIER: "[l]e terme de 'nom commercial' est couramment employé, parce que la plupart des exploitations se placent dans le cadre d'un fonds de commerce; mais il est bien évident que des problèmes de dénomination analogues peuvent se poser por entreprises différentes" (in Le Droit de la Propriété Industrielle, cit., p. 659)
} 
Não obstante, doutrina e jurisprudência mostraram-se vacilantes, não havendo consenso sobre a adequada proteção ao nome de empresa, a ponto de GAMA CERQUEIRA afirmar que "se a questão dos efeitos do registro de marcas é a moléstia crônica de nossa propriedade industrial, a questão do nome comercial parece constituir seu mal incurável" 5 . No mesmo sentido, HeRMANo DUVAL ressaltou que "a tutela do nome comercial, título de estabelecimento e insígnia é bastante confusa" 6 .

Passadas décadas, a proteção ao nome de empresa continua problemática, como recentemente salientou DENIS BORGES BARBOSA: "como um elemento inegavelmente integrante da propriedade industrial - o nome comercial, ou melhor, os nomes empresariais - não foi incluído na Lei 9.279/96. Certamente deveria tê-lo sido, pois subsistem todos os problemas de uma proteção múltipla, de base estadual, à qual se soma a aplicação do art. $8^{\circ}$ da CUP. Um verdadeiro caos" 7 .

Contribuiu decisivamente para este quadro crítico o fato de o nome de empresa, ao longo dos anos, carecer de legislação específica, sendo sua formação e proteção regidas por disposições esparsas de nosso direito positivo. Esta carência de legislação especial sobre técnica onomatológica, somada a inúmeros debates doutrinários e jurisprudenciais acerca de sua natureza, âmbito de proteção e conflito com outros sinais distintivos, dificultou sobremaneira sua eficaz proteção, especialmente através de ações judiciais ${ }^{8}$.

A partir da década de 90, foram assentando-se em nossa jurisprudência, principalmente no recém criado STJ, princípios gerais aplicáveis aos nomes de empresas, dirimindo as principais questões ${ }^{9}$.

\footnotetext{
${ }^{5}$ Cf. parecer em RT 249/37

${ }^{6}$ Duval, Hermano. Concorrência desleal. São Paulo: Saraiva, 1976, p. 169

${ }^{7}$ BARBOSA, Denis Borges. Uma introdução à propriedade intelectual, Vol. I. e II. Rio de Janeiro: Lumen Juris, 1997, p. 928.

${ }^{8}$ RUBENS REQUIÃO criticou agudamente a tendência de descodificação em matéria de propriedade industrial, especialmente no tocante ao nome comercial: "[a] história do direito da propriedade industrial no Brasil, nestes últimos anos, tem revelado precisamente um movimento contrário, isto é, a sua dispersão e desagregação, ao contrário da aglutinação em um só corpo”. (...) Não é preciso ter imaginação para compreender que indústria, a que se refere a denominação propriedade industrial, diz respeito à atividade produtiva. Indústria, na sua acepção científica, constitui toda a atividade do homem ligada à produção da riqueza e, nesse sentido, se usa da expressão indústria comercial. O nome comercial, o título de estabelecimento, constituem, portanto matéria pertinente à codificação da propriedade industrial" (in Curso de Direito Comercial, São Paulo: Saraiva, 1982, 13ª ed., p. 119/120, nº 79)

${ }^{9}$ GABRIEL F. LEONARDOS sintetiza as principais questões solucionadas pelo STJ: (a) a que requisitos o nome empresarial deve atender para fazer jus a proteção; (b) qual o âmbito de proteção geográfico da proteção aos nomes empresariais; (c) como se solucionam os conflitos entre nomes empresariais e marcas; e (d) a proteção se estende a todas as atividades ou é restrita às atividades exercidas pelo titular do nome empresarial (Cf. A proteção ao nome empresarial, in Propriedade Intelectual: sinais distintivos e tutela judicial e administrativa, Coord. Wilson Pinheiro Jabur e Manoel J. Pereira dos Santos. São Paulo: Saraiva, 2007, p. 136)
} 
Surge, então, o Código Civil trazendo novas disposições sobre o nome de empresa, muitas delas retrógradas e antagônicas à jurisprudência desenvolvida nos últimos anos. Nesse sentido, ressalte-se que a comissão, presidida por Miguel Reale para a elaboração do novo código civil, apresentou nos idos de 1972 o projeto que viria, em 1975, a converter-se no Projeto de Lei do Poder Executivo 634-B, enviado à Câmara dos Deputados. Este projeto, somente após 17 anos de tramitação, foi finalmente convertido na Lei $\mathrm{n}^{\circ}$ 10.406, de 10 de janeiro de 2002, que entrou em vigor em dia 11 de janeiro de 2003.

Assim, a redação do livro do Direito de Empresa, chamado no anteprojeto de 1972 de livro da Atividade Negocial, refletiu, evidentemente, o entendimento jurisprudencial e doutrinário da época, não tendo sido sofrido nenhuma alteração (rectius, atualização) durante a tramitação do projeto. Logo, o Código Civil em matéria de nome empresarial encetou-se já velho, desconsiderando a jurisprudência e as leis posteriores atinentes ao tema.

Decerto, as modificações trazidas pelo Código Civil impactarão na jurisprudência, sendo oportuno analisá-las sob um enfoque atual.

\section{A justificativa da escolha}

O desafio que assumimos, decerto arriscado, foi tratar do nome de empresa de forma ampla, procurando expor e analisar as principais questões envolvendo o nome, não nos limitando a estudar um ou outro aspecto, tais como: conceito, natureza jurídica ou tutela.

Fomos motivados pela ausência de obra atualizada e específica sobre o tema. A doutrina sobre o nome de empresa é abundante entre o final do século XIX e primeira metade do século XX, onde encontramos os trabalhos mais aprofundados sobre o tema. De lá para cá pouco se produziu sobre o nome de empresa, não obstante existirem valiosos artigos publicados a respeito.

Contribuiu para nossa escolha, também, a desalinhada e vacilante jurisprudência sobre o nome de empresa, não fornecendo aos jurisdicionados interpretação harmoniosa quanto à sua disciplina jurídica.

Logo, o objetivo deste estudo é esmiuçar os contornos do nome de empresa, de maneira clara e à luz da hodierna legislação, doutrina e jurisprudência, analisando a problemática existente em relação à sua proteção. 


\section{Os limites do trabalho}

Ressalte-se, contudo, que o objeto deste estudo restringe-se à proteção do nome de empresa no Brasil. Não serão analisados, assim, outros sinais distintivos do empresário (como as marcas, insígnias e títulos de estabelecimento), mas, evidentemente, a eles faremos referência ao longo do trabalho, ainda que perfunctoriamente, para melhor compreensão do nome de empresa.

Nosso trabalho também não abordará a proteção de nome de empresa em outros países, até mesmo porque tal mister é de grande complexidade, que exigiria um trabalho autônomo, haja vista a confusão verificada no ordenamento jurídico de diversos países quanto à natureza e conceito de nome empresarial. Tal limitação não exclui, por certo, a menção aos tratados internacionais ratificados pelo Brasil, para proteção do nome de empresa no exterior.

No que concerne à tutela do nome de empresa em juízo, faremos referência às ações cabíveis, nas esferas cível e criminal, mas não nos deteremos profundamente nas questões processuais, tratando-as apenas de forma sintética.

\section{Plano de trabalho}

Em suma, o trabalho é iniciado trazendo noções propedêuticas sobre o nome, traçando a distinção entre o nome no plano pessoal e empresarial, para, então, tratar especificamente do nome de empresa, conceituando-o e definindo suas modalidades, função, natureza jurídica e extinção. Feito isso, trataremos do nome de empresa em espécie, realçando as regras de formação da firma do empresário individual e das firmas e denominações de cada um dos tipos societários.

Em seguida, abordaremos a proteção internacional do nome de empresa, para, após, tratar de sua tutela jurídica no Brasil, desde o nascimento da proteção até o conflito com outros sinais distintivos do empresário. 


\section{Capítulo I \\ O DIREITO À IDENTIDADE}

\section{Considerações iniciais}

Ao longo da história, os direitos humanos ${ }^{10}$ foram paulatinamente reconhecidos e afirmados como um "ideal a ser atingido por todos os povos e todas as nações e como objetivo de cada indivíduo e cada órgão da sociedade" ${ }^{11}$.

Especialmente durante a segunda metade do século XVIII, os homens passam a ser considerados essencialmente iguais e dotados de liberdade, fundamentos estes inerentes para a afirmação da existência de direitos humanos ${ }^{12}$.

A Declaração Universal dos Direitos Humanos, aprovada pela Assembléia Geral das Nações Unidas em 10 de dezembro de 1948, em seu art. $1^{\circ}$, dispôs que "todos os homens nascem livres e iguais em dignidade e direitos. São dotados de razão e consciência e devem agir em relação uns aos outros com espírito de fraternidade".

Os direitos humanos são fundamentados na dignidade humana, valor intrínseco da pessoa. Em sendo assim, a condição de pessoa é, portanto, o requisito único para titularidade de tais direitos.

Reconheceu-se, destarte, que o homem tem direito de ser respeitado pelo simples fato de sua humanidade, ou seja, por sua recognição como pessoa. Segundo o art $4^{\circ}$ da referida Declaração Universal dos Direitos Humanos: "todo homem tem direito de ser, em

\footnotetext{
${ }^{10}$ J. J. Gomes CANOTILHO distingue as expressões direitos do homem ou direitos humanos de direitos fundamentais. Diz o constitucionalista português: "[s]egundo a sua origem e significado poderíamos distingui-las da seguinte maneira: direitos do homem são direitos válidos para todos os povos e em todos os tempos (dimensão jusnaturalista-universalista); direitos fundamentais são os direitos do homem, jurídicoinstitucionalmente garantidos e limitados espacio-temporalmente. Os direitos do homem arrancariam da própria natureza humana e daí o seu carácter inviolável, intemporal e universal; os direitos fundamentais seriam os direitos objectivamente vigentes numa ordem jurídica concreta" (in Direito constitucional e teoria da constituição, $4^{\text {a }}$ edição. Coimbra: Livraria Almedina, p. 387)

${ }^{11}$ Prelúdio da Declaração Universal dos Direitos Humanos de 1948

12 É o que se verifica na Bill of Rights de Virgínia, de 16 de junho 1776 (também conhecida como Declaração de direitos do bom povo da Virgínia), referindo-se inicialmente à liberdade e à igualdade, assim como a Declaração Francesa dos Direitos do Homem e do Cidadão de 1789, que em seu artigo $1^{\circ}$ dizia que "os homens nascem e permanecem livres e iguais em direitos". A fraternidade veio a ser reconhecida apenas com a Declaração Universal de Direitos Humanos de 1948. Vale referência, ainda, à Declaração de Direitos Humanos de Viena de 1993, aceita por 171 Estados, que reforça o legado da Declaração de 1948, endossando que os direitos humanos são universais, indivisíveis, interdependentes e inter-relacionados.
} 
todos os lugares, reconhecido como pessoa perante a lei”. Para COMPARATO, é "[e]ste o princípio supremo em matéria de direitos humanos" ${ }^{13}$.

A pessoa considerada em si mesma e em suas projeções na sociedade possui direitos inatos, previstos e protegidos pelo ordenamento jurídico. São os denominados direitos da personalidade ${ }^{14-15}$, que dão conteúdo à personalidade ${ }^{16}$.

Os direitos da personalidade são, assim, o conjunto de faculdades jurídicas reconhecidas à pessoa humana, cujo objeto são os bens jurídicos em que se convertem os diversos aspectos da pessoa do sujeito tomado em si mesmo e em suas projeções e prolongamentos ${ }^{17}$.

Tais direitos são previstos "exatamente para a defesa de valores inatos no homem, como a vida, a higidez física, a intimidade, a honra, a intelectualidade e outros tantos" 18 . Ou ainda, no dizer de FÁBIO DE MATTIA, "o objeto dos direitos da personalidade não é a pessoa considerada em sua totalidade. São suas realidades antropológicas: corpo, vida, saúde, honra e liberdade" ${ }^{19}$.

Em interessante artigo, LiMONGI FRANÇA, definiu cerca de sessenta espécies de direitos da personalidade, classificados em três grupos fundamentais: Direito à Integridade Física, como o Direito ao Corpo e as partes separadas deste, morto ou vivo; Direito à Integridade Intelectual, como o Direito de Autor; e Direito à Integridade Moral, como o Direito à Identidade, como o Direito à Identidade Familiar e Individual ${ }^{20-21-22}$.

\footnotetext{
${ }^{13}$ COMPARATO, Fábio Konder. A afirmação histórica dos direitos humanos, $3^{\text {a }}$ ed. rev. e ampl., São Paulo: Saraiva, 2003, p. 228

${ }^{14}$ BITTAR resume as divergências doutrinárias quanto à denominação de tais direitos, informando que a expressão "direitos da personalidade" foi adotada por Gierke, Ferrara, Adriano de Cupis, Orlando Gomes, Limongi França, Antonio Chaves, Orozimbo Nonato e Anacleto de Oliveira. "Direitos essenciais" ou "direitos fundamentais" da pessoa por Ravà, Gangi; "direitos sobre a própria pessoa" por Windgcheid e Campogrande; "direitos individuais" por Kohler e Garreis; "direitos pessoais” por Wachter e Bruns; e, finalmente, "direitos personalíssimos" por Pugliati e Rotondi (In Os direitos da personalidade, $1^{\mathrm{a}}$ ed., Rio de Janeiro: Forense Universitária, 1989, p. 2).

${ }^{15}$ A personalidade, atributo jurídico da pessoa, é, vale dizer, anterior ao nome. O nome é, pois, um dos atributos da personalidade.

${ }^{16}$ DE CUPIS, Adriano. Os direitos da personalidade. Trad. de Adriano Vera Jardim e Antônio Miguel Caeiro. Lisboa: Livraria Morais, 1961, p. 17

${ }^{17}$ SAHM, Regina. Direito à imagem no direito civil contemporâneo: de acordo com o novo código civil, Lei $n^{\circ}$ 10.406, de 10-1-2002, São Paulo: Atlas, 2002, p. 20

${ }_{18}$ BITTAR, Carlos Alberto. Os direitos da personalidade, cit.,p. 1

${ }^{19}$ De MATTIA, Fábio. Direitos da personalidade. In LIMONGI FRANÇA, Rubens (Coord.). Enciclopédia Saraiva de Direito. São Paulo: Saraiva, 1977, v. 25, p.152/153

${ }^{20}$ FRANÇA, Rubens Limongi. In Direitos da personalidade - coordenadas fundamentais. Revista da Academia Brasileira de Letras Jurídicas, nº 4, p. 37-50

${ }^{21}$ BITTAR adota classificação similar, dividindo os direitos da personalidade em: "a) físicos, como a vida, o corpo (próprio ou alheio); as partes do corpo; o físico, a efígie (uma imagem); a voz; o cadáver; a locomoção; b) psíquicos, como: as liberdades (de expressão; de culto ou de credo; etc.); a higidez psíquica; a intimidade; os segredos (pessoais e profissionais) e c) morais, como: o nome (e outros elementos de identificação); a
} 
Para CANOTILHO, "os direitos da personalidade abarcam certamente os direitos de estado (por ex.: direito à cidadania), os direitos sobre a própria pessoa (direito à vida, à integridade moral e física, direito à privacidade), os direitos distintivos da personalidade (direito à identidade pessoal, direito à informação) e muitos dos direitos de liberdade (liberdade de expressão)" 23.

Embora o tema dos direitos da personalidade seja apaixonante e denso, interessanos aqui exclusivamente o direito à integridade moral, que toma a pessoa como ser social, ou seja, em sua projeção em um contexto coletivo; e, mais especificamente, o direito fundamental da pessoa à identidade (como direito distintivo da personalidade), que constitui o elo de ligação entre o indivíduo e a sociedade, e, mais precisamente, o nome, que se consubstancia no elemento básico de associação.

O Direito ao nome, destacou LIMONGI FRANÇA, “é a principal espécie das categorias que integram o Direito à Identidade, sobressaindo-se em meio a outras variedades, como o agnome, o nome vocatório e o pseudônimo, além de outros" ${ }^{24}$.

\section{A identificação das pessoas}

Mas o que é nome? Mister se faz entender que é nome $e^{25}$, bem como sua função na humanidade. Isso porque a ação de nomear coisas e, principalmente, o próprio homem remonta aos primórdios da civilização. Diz a bíblia que: "Deus incumbiu ao homem a responsabilidade de dar nome àquilo a que Êle dera o ser" ${ }^{26}$. E assim, o homem deu nome a cada um dos seres ("os peixes do mar, as aves do céu, os animais domésticos, todas as feras e todos os répteis que rastejam sobre a terra" ${ }^{27}$ ) "o que significa, segundo velhíssima crença, submeter o nomeado ao poder do nomeante" 28.

reputação (ou boa fama); a dignidade pessoal; o direito moral de autor (ou de inventor); o sepulcro; as lembranças de família e outros" (in Os direitos da personalidade, cit., p. 59)

${ }_{22}$ Walter MORAES posiciona-se contra uma extensa relação de bens de personalidade, considerando somente as partes do homem in natura, as quais se resumiriam em uns poucos direitos básicos (cf. Concepção tomista de pessoa. Revista dos Tribunais. São Paulo: ano 73, v. 590, 1984, p. 21)

${ }_{23}^{23}$ J. J. Gomes CANOTILHO Direito constitucional e teoria da constituição, cit., p. 390

${ }^{24}$ FRANÇA, Rubens Limongi. O direito ao nome civil e o seu uso industrial, parecer datado de 01/11/1994, citado por Newton Silveira em Estudos e pareceres, cit., p. 68.

${ }^{25}$ A palavra nome, conforme o Dicionário Houaiss da língua portuguesa, surgiu em 1346 vinda do latim “nom-en,nom-in-is, de gnom-en (com aférese do g), êste de gnosc-ere” conforma informa Carlos Góes citado por Justino Vasconcelos, in Das firmas e denominações comerciais, Rio de Janeiro: Revista Forense, 1.957, p. 5

${ }^{26}$ Gênesis, II, 19, 20

${ }^{27}$ Gênesis, I, 26

${ }^{28}$ COMPARATO, Fábio Konder. A afirmação histórica dos direitos humanos, cit., p. 2. 
O nome, pode-se dizer, não cria o ser, apenas o identifica, individualiza, distinguindo dos demais seres. O nome torna o ser único e independente; pronunciar o nome de algo é tê-lo presente. Põe-se o nome no lugar da coisa que designa; é sua representação mental ${ }^{29-30}$.

Para os antigos, ensinou COMPARATO, "o nome exprime a essência do ser. Um homem sem nome é insignificante, em todos os sentidos da palavra (Jô 30.8); é como se não existisse (Eclesiastises 6, 10)" ${ }^{31}$.

A função do nome é, assim, individualizar as coisas e as pessoas ${ }^{32}$ no mundo exterior, diferenciando-as dos demais. No dizer de DI FRANCO, "o nome, em seu significado mais amplo, é um produto intelectivo, uma necessidade do espírito na sua correspondência com o mundo exterior" ${ }^{33}$.

As Institutas de Justiniano, Liv. 2, Tít. 20, § 29, dizem que os nomes foram inventados para significarem os homens; nomina significandorum hominum gratia reperta sunt ${ }^{34}$. O homem tem, portanto, como pessoa, direito fundamental à identidade "que se constitui no elo de ligação entre o indivíduo e a sociedade em geral" ${ }^{35-36}$, sendo o nome o principal dos elementos básicos de associação. O nome é o meio normal de efetivação da referida identidade ${ }^{37}$.

A pessoa, sujeito capaz de direitos, centro das relações sociais e jurídicas, é assinalada pelo nome que recebe no registro civil, e que a acompanha toda a vida. $\mathrm{O}$ nome

\footnotetext{
${ }^{29}$ VASCONCELOS, Justino. Das firmas e denominações comerciais, cit., p. 7/8

${ }^{30}$ Segundo Di FRANCO: "[i]l nome, nella sua più ampia significazione, non è che un prodotto intellettivo, una necessita dello spirito nella sua corrispondenza col mondo esteriore: è la designazione delle idee e degli esseri, è l'etichetta dei pensieri, delle cose, delle persone, che l'uomo impone a tutto cio che sente, crede, vede, intende" (Trattato della Proprietà Industriale, Società Editrice Libraria, Milano, 1.933, p. 352/353) ${ }^{31}$ COMPARATO, Fábio Konder. A afirmação histórica dos direitos humanos, cit., p. 2, nota 1.

${ }^{32}$ Segundo o art. VI da Declaração Universal dos Direitos Humanos, aprovada pela Assembléia Geral das Nações Unidas em 10 de dezembro de 1948, todo homem tem direito de ser, em todos os lugares, reconhecido como pessoa. A pessoa, do grego prósopon depois traduzida por persona pelos romanos, "possui uma identidade singular, inconfundível com a de outro qualquer" (apud COMPARATO in Afirmação histórica dos direitos humanos, cit., p. 27), essa identidade é reconhecida e individuada pelos demais membros de uma coletividade pelo nome.

${ }^{33}$ E continua o autor: "è la designazione delle idee e degli esseri, è l'etichetta dei pensieri, delle cose, delle persone, che l'uomo impone a tutto ciò che sente, crede, vede, intende" (Trattato della proprietà industriale, cit., p. 353).

${ }^{34}$ Cf. MendonçA, José Xavier Carvalho de. Tratado de Direito Comercial Brasileiro, Rio de Janeiro: Freitas Bastos, 1957, p. 143

${ }^{35}$ BITTAR, Carlos Alberto. Os direitos da personalidade, cit, p. 120

${ }^{36}$ Anota BITTAR que "o nome e outros sinais identificadores da pessoa são os elementos básicos de associação de que dispõe o público em geral para o relacionamento normal, nos diversos núcleos possíveis: familiar; sucessório; negocial; comercial e outros. Cumpre, aliás, duas funções essenciais: a de permitir a individualização da pesoa e a de evitar a confusão com outra. Possibilita seja a pessoa imediatamente lembrada, mesmo em sua ausência e a longas distâncias" (Ibidem).

${ }^{37}$ FRANÇA, Rubens Limongi. Do nome civil das pessoas naturais, cit., p. 138
} 
do indivíduo é o símbolo da sua personalidade, o sinal que o particulariza, caracteriza e distingue na vida social, o signum fiduciae et credulitatis ${ }^{38}$.

\section{O direito/dever ao nome}

Desta forma, dentre os direitos de personalidade encontra-se o inato direito ao nome $^{39}$, que foi, finalmente ${ }^{40}$, inserido explicitamente em nosso Código Civil, o qual dispõe em seu artigo 16 que "toda pessoa tem direito ao nome, nele compreendidos o prenome e o sobrenome" ${ }^{41}$. Toda pessoa tem um dever-direito ao nome ${ }^{42}$, que emerge da própria natureza das coisas e que impõe a necessidade de que cada um seja identificado e não seja confundido com outrem ${ }^{43-44}$.

O nome civil, assim, exerce duas funções: a primeira, de caráter subjetivo ou privado, consiste na identificação/distinção pessoal do indivíduo particularmente considerado $^{45-46}$, ou seja, um reflexo do próprio direito à identidade; a segunda, que considera o nome como instituição de ordem $_{\text {pública }}{ }^{47}$, refere-se ao grande interesse que tem a sociedade na identificação das pessoas, para delas poder exigir com eficácia as obrigações que respeitam a cada uma, como tributo ordenado ao Bem Social ${ }^{48}$. A identidade de cada um dos membros de uma sociedade é fator de vida indispensável ${ }^{49-50}$.

\footnotetext{
${ }^{38}$ MENDONÇA, José Xavier Carvalho de. Op. cit., p. 143

${ }^{39}$ Ensinou BITTAR que o bem jurídico tutelado é a identidade, que se considera como atributo ínsito na personalidade humana. O direito essencial é o ao nome, mas também recebem proteção os acessórios (como o pseudônimo, a alcunha e o hipocorístico, este a designação carinhosa, geralmente pelos íntimos). Envolve, ainda, a doutrina do nome a defesa da pessoa jurídica, exatamente para distingui-la no imenso universo empresarial, in Os direitos da personalidade, cit., p. 121

${ }^{40}$ Nos idos de 1888 já salientava Affonso CELSO que "nunca foi previdente a legislação pátria acerca do nome, civil ou commedial, sua propriedade e uso" (in Marcas industriaes e nome commercial. Rio de Janeiro: B. L. Garnier, 1888, p. 97).

${ }^{41}$ Clóvis BEVILÁQUA negava ao nome civil o caráter de direito, pois entendia que não há direito de personalidade, sendo o nome apenas uma manifestação dela (in Teoria geral do Direito Civil, n. 55)

${ }^{42}$ Sobre o direito ao nome e as teorias contrárias à existência do direito ao nome vide R. Limongi França, in Do Nome Civil das Pessoas Naturais, cit.

${ }^{43}$ FrANÇA, Rubens Limongi. Op. cit., p. 149

${ }^{44}$ No dizer de DI FRANCO: "[p]er designare e distinguire le persone ai fini della vita civil la legge impone e disciplina l'uso di apposito nome, così detto, patronímico" (Trattato della Proprietà Industriale, cit. p. 353)

${ }^{45} \mathrm{O}$ nome não tem valor por si mesmo, mas sim mercê de sua função identificadora. Em outras palavras, o direito não é ao nome em si, às palavras que o compõe, é, na verdade, à identidade do sujeito, da pessoa.

${ }^{46}$ Sob este aspecto o nome é considerado como direito da personalidade, como atributo inerente à condição de pessoa.

${ }^{47} \mathrm{Na}$ esteira das afirmações de PlANIOL, comentadas por SPENCER VAMPRÉ (em Do nome civil: sua origem e significação sociologica; teorias que explicam; suas alterações; direitos e deveres correlativos, Rio de Janeiro: Brighiet, 1935) e R. LIMONGI FRANÇA (na obra citada) e PAUL ROUBIER (Le Droit de la Propriété Industrielle, Partie Spéciale: Paris: Éditions Du Recueil Sirey, 1952, p. 669).

${ }^{48}$ FrANÇA, Rubens Limongi. Op. cit., p. 174

${ }^{49}$ CARVALHO DE MENDONÇA salienta que grande é a controvérsia sobre o caráter jurídico do nome civil. Se para muitos é uma propriedade (cita o autor a jurisprudência francesa), propriedade sobre coisa corpórea, ou,
} 


\section{4. $O$ conceito de nome}

Nome civil é, na lição de LIMONGI FRANÇA, a designação pela qual se identificam e distinguem as pessoas naturais nas relações concernentes ao aspecto civil da sua vida jurídica $^{51-52-53}$. É, a um só tempo, direito e obrigação da pessoa, como decorrência de sua personalidade e, por conseguinte, da vida em sociedade, pois na sociedade civil avulta sempre o interesse na identificação dos indivíduos, para possibilitar a própria existência harmônica, necessária ao bem estar social.

Também às pessoas jurídicas é reconhecido o direito ao nome, como um atributo de sua personalidade jurídica ${ }^{54}$, ou seja, a partir de seu nascimento, que se dá com a inscrição do ato constitutivo no respectivo registro, precedida, quando necessário, de autorização ou aprovação do Poder Executivo ${ }^{55}$, a pessoa jurídica ${ }^{56}$ tem direito ao uso exclusivo de seu nome empresarial.

Da mesma forma, ensina NEWTON SILVEIRA “que o nome civil do cidadão constitui a um só tempo um direito e uma obrigação, não podendo uma pessoa alterá-lo ou substituílo, senão nos casos em que a lei autoriza, mas estando preservado, como elemento da personalidade, na mesma medida desta, o nome que o comerciante tenha adotado no

propriedade sui generis, para outros não passa de meio de classificação organizada pela sociedade de etiqueta ou de número de matrícula, visto ser instituição de polícia civil (cita o autor o já referido Planiol). Escritores, especialmente alemães, dão ao nome o caráter de direito pessoal.

${ }^{50} \mathrm{Na}$ lição de ROUBIER : "[e]n réalité il n'y a guère de droit au nom. Le nom est une de ces situations juridiques entièrement objectives, comme il en existe tant en droit public: on n'a pas seulement le droit de porter son nom, on en a aussi l'obligation” (Le Droit de la Propriété Industrielle, cit, p. 669).

${ }^{51}$ FrANÇA, Rubens Limongi. Op. cit., p. 136/137

52 "Chi porta un dato nome", disse DI FRANCO, "há diritto di usarne nell'esplicazione di ogni sua attività. Il nome infatti deve distinguere l'uomo che vive in società accompagnandolo in tutte le sue manifestazioni" (Trattato della Proprietà Industriale, cit, p. 355)

${ }^{53}$ BITTAR entende que para fins de proteção o nome compreende: o patronímico, o apelido de família, ou, ainda, o sobrenome (que designa o núcleo a que pertence o ser); o prenome (o nome propriamente da pessoa); o pseudônimo (nome convencional fictício, sob o qual oculta a sua identidade o interessado, para fins artísticos, literários, políticos, desportivos etc.); e a alcunha (ou,na linguagem comum, o apelido: designação dada por terceiro, que compreende algum aspecto ou faceta especial do ser). Também são protegidos os títulos de identificação e honoríficos (como os títulos acadêmicos, profissionais e de nobreza) e os sinais figurativos (como o sinete, com as iniciais da pessoa, e o brasão, ou escudo, com os símbolos e as cores da família). Acrescente-se, ainda, o nome artístico (adotado no âmbito das artes, mediante composição). Cf. Os direitos da personalidade, cit., p. 121.

${ }^{54}$ Como expressamente reza o art. 52, do CC.

${ }^{55}$ Cf. art. 45, do CC

${ }^{56}$ Nos termos do art. 44, do CC, são pessoas jurídicas de direito privado: as associações, as sociedades, as fundações, as organizações religiosas e os partidos políticos. 
comércio (que, no caso do comerciante individual, deve, necessariamente, coincidir com o nome civil) é preservado pela lei da usurpação e da imitação" 57.

\section{O nome no plano pessoal}

Como visto, a toda pessoa física é necessariamente assegurado o direito ao nome civil $^{58}$, ainda que possa ser idêntico a outro já existente.

A Lei de Registros Públicos dispõe, em seu art. 54, que o assento do nascimento deverá conter, entre outros, o nome e o prenome, que forem postos à criança ${ }^{59}$. Logo o nome civil é composto, necessariamente, por nome ou prenome (designação especial do indivíduo, a qual normalmente é buscada em personagens históricos ou bíblicos) e pelo sobrenome ou patronímico (também chamado de nome de família), que designa a origem e a família a que pertence o indivíduo.

A pessoa adquire o nome civil com o registro de seu nascimento (neste caso por atribuição de outrem ${ }^{60}$ ), pelo casamento ${ }^{61}$, ou ainda por adoção, como apelido, pseudônimo ou o nome abreviado usado como firma comercial ${ }^{62}$. Repise-se que há obrigatoriedade no uso do nome civil, haja vista a função pública que exerce, identificando o indivíduo perante a sociedade.

O nome civil acompanha a pessoa por toda sua existência, não podendo ser alterado ou substituído, exceto nos casos em que a lei autoriza ${ }^{63}$. Vige o princípio da imutabilidade

\footnotetext{
${ }^{57}$ SILVEIRA, Newton. Licença de uso de marca e outros sinais distintivos. São Paulo: Saraiva, 1984., p. 9 ${ }^{58}$ Cf. art. 16, do CC

${ }^{59}$ Lei 6015 , de 31 de dezembro de 1973. Diz ainda a lei que quando o declarante não indicar o nome completo, o oficial lançará adiante do prenome escolhido o nome do pai, e na falta, o da mãe, se forem conhecidos e não o impedir a condição de ilegitimidade, salvo reconhecimento no ato (art. 55); e que os oficiais do registro civil não registrarão prenomes suscetíveis de expor ao ridículo os seus portadores. Quando os pais não se conformarem com a recusa do oficial, este submeterá por escrito o caso, independente da cobrança de quaisquer emolumentos, à decisão do Juiz competente (art. 55, § único).

${ }^{60}$ Segundo reza o art. 52, da Lei de Registros Públicos, a declaração de nascimento e a, conseqüente, indicação do nome e prenome dados à criança, deverá ser feita pelo pai; em sua falta ou impedimento pela mãe; no impedimento de ambos, o parente mais próximo; em sua falta ou impedimento os administradores do hospital ou os médicos e parteiras; pessoa idônea da casa em que ocorrer o parto, sendo fora da residência da mãe; as pessoas encarregadas da guarda no menor.

${ }^{61}$ Qualquer nubente, querendo, poderá acrescer ao seu o sobrenome do outro ( $\$ 1^{\circ}$, do art. 1.565 , do CC)

${ }^{62}$ Cf. parágrafo $1^{\circ}$, do art. 57, da Lei de Registros Públicos.

${ }^{63}$ É pacifico na doutrina e jurisprudência a alteração de nomes suscetíveis de expor ao ridículo seus portadores. Os próprios oficiais do registro civil são autorizados, por lei, a não registrar nomes vexatórios (parágrafo único, do art. 55, da Lei de Registros Públicos). Tem-se, também, permitido a alteração do nome desde que não haja prejuízo à ancestralidade, nem à sociedade, inclusive com a supressão de um dos apelidos de família (nesse sentido: STJ, $3^{\text {a }}$ T., REsp 662.799/MG, Rel. Min. Castro Filho, j. em 08/11/2005, DJ 28/11/2005, p. 279; $3^{\text {a }}$ T., REsp 538.187/RJ, Rel. Min. Nancy Andrighi, j. em 02/12/2004, DJ 21/02/2005, p. 170; $3^{\mathrm{a} T}$., REsp 146.558/PR, Rel. Min. Castro Filho, j. em 19/11/2002, DJ 24/02/2003, p. 221; $3^{\mathrm{a} T}$., REsp 213.682/GO, Rel. Min. Ari Pargendler, j. em 05/09/2002, DJ 02/12/2002, p. 305; $4^{\text {a }}$ T., REsp 66.643/SP, Rel.
} 
do prenome, previsto no art. 58 da Lei de Registros Públicos, o qual tem recebido, todavia, certo temperamento, admitindo-se, excepcionalmente, a alteração do patronímico, desde que presente justa motivação e prévia intervenção do Ministério Público ${ }^{64}$.

O nome civil, ou sua alteração, deverá ser averbado à margem do assento, dandolhe publicidade. O registro do nome civil garante à pessoa proteção, podendo, no dizer de ASCARELLI, “invocar la atribuición del nombre que le corresponde, así como para impedir su uso a quien no tenga derecho, siempre que - sea o no culposa la atribuición ilícita (1) le pueda resultar un perjuicio (2), contando después con el derecho a obtener el resarcimiento del dano cuando exista um daño actual, culposamente ocasionado" ${ }^{65}$.

Nosso CC expressamente veda o emprego do nome por outrem em publicações ou representações que a exponham ao desprezo público, ainda quando não haja intenção difamatória, bem como o uso do nome em propaganda comercial ${ }^{66}$.

O nome civil, assim como o pseudônimo, embora possa ser considerado um sinal distintivo já que identifica a pessoa na vida social, não é considerado um bem autônomo, sendo, portanto, inestimável (ou seja, não se lhe atribui um valor econômico) e inegociável (i.e., não pode ser objeto de circulação). Portanto, o nome civil está fora do âmbito da atividade econômica.

\section{O nome no plano empresarial}

Ensina Di FRANCO que sempre que o nome do indivíduo for adotado para o fim de exercício de indústria ou de comércio, ele assume a veste jurídica de nome comercial ${ }^{67-68}$. No orbe da atividade empresarial, o nome passa a ser considerado um bem imaterial, um sinal distintivo do empresário no exercício da empresa. Assim, submete-se a regime

\footnotetext{
Min. Sálvio de Figueiredo Teixeira, j. em 21/10/1997, DJ 09/12/1997, p. 64707; $3^{\text {a }}$ T., REsp 729.429/MG, Rel. Min. Nancy Andrighi, j. em 10/11/2005, DJ 28/11/2005, p. 288). Autoriza-se, também, a alteração do nome quando o sujeito é conhecido no meio social pelo apelido que pretende adotar (Vide REsp 538.187/RJ, REsp 146.558/PR, REsp 213.682/GO e REsp 66.643/SP citados acima); assim como quando se pretende acrescer ou excluir sobrenome de genitores e/ou padastros (STJ, $2^{\text {a }}$ Seção, REsp 284.300/SP, Rel. Min. Ruy

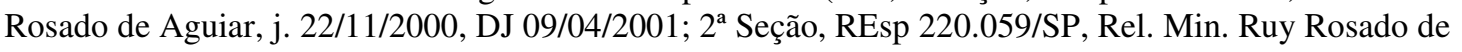
Aguiar, j. em 22/11/2000, DJ 12/02/2001 p. 92; e REsp 66.643/SP, já citado)

${ }^{64} \mathrm{O}$ simples fato da homonímia não autoriza a alteração de nome, sendo necessária a exposição a circunstâncias vexatórias e de constrangimento (cf. STJ, $3^{\text {a }}$ T., REsp 647.296/MT, Rel. Min. Nancy Andrighi, j. em 03/05/2005, DJ 16/05/2005, p. 348).

${ }^{65}$ In Teoría de la concurrencia y de los bienes inmateriales. Barcelona, Bosch, 1970, p. 356

${ }^{66}$ Cf. arts. 17 e 18.

${ }^{67}$ DI FRANCO, Luigi. Trattato della Proprietà Industriale, cit., p. 355

${ }^{68}$ No mesmo sentido, ASCARELLI, in op. cit., p. 384/385
} 
jurídico próprio, previsto, como será visto linhas abaixo, na legislação comercial e de propriedade industrial.

Aqui, o nome comercial, empresarial ou de empresa ${ }^{69}$, é considerado como instrumento de união entre a clientela e determinadas pessoas que exercem uma empresa, de forma que permitam aos clientes a individualização daqueles que exercem a empresa, assegurando, desde modo aos empresários sua identificação e procura pelos clientes ${ }^{70}$.

O nome exercita uma função jurídica importante: aquela de designar uma determinada pessoa em suas relações jurídicas e de permitir que esta pessoa se faça reconhecer e angarie clientela em qualquer atividade que se desenvolva ${ }^{71}$.

Daí a necessidade de tutelar-se a identificação dos empresários, outorgando-lhes direito absoluto sobre seus sinais distintivos, especialmente ao nome comercial. Neste ponto, difere do nome civil, em que, a rigor, é permitida a homonímia. Este uso exclusivo, no plano empresarial, surge da imperiosa necessidade de elidir confusão no campo concorrencial.

Importante destacar, também, que a disciplina do nome empresarial não está restrita exclusivamente aos empresários e sociedades empresárias. Ao longo deste trabalho, verificaremos que a proteção é estendida, por expressa disposição legal, às fundações, associações e sociedades simples, assim como àqueles que exercem profissão intelectual, de natureza científica, literária ou artística, ainda com o concurso de auxiliares ou colaboradores, salvo se o exercício da profissão constituir elemento de empresa.

A antiga lição de ASCARELLI permanece atual: "[a]unque la disciplina del nombre comercial ha sido elaborada por el Derecho mercantil, es propia, no obstante, de todos los empresários, volviendo a destacarse, bajo este aspecto, el alcance de la realizada unificación del Derecho privado" 72 .

\section{As distintas funções exercidas pelo nome}

O nome civil, assim como o nome empresarial, de um sujeito de direito (pessoa física ou jurídica) exerce duas importantes funções em suas relações jurídicas, que podem ser, assim, resumidas:

\footnotetext{
${ }^{69}$ Adiante estudaremos as diferentes nomenclaturas e acepções.

${ }^{70}$ AsCARELLI, Tullio. Teoría de la concurrencia y de los bienes inmateriales, cit. p. 357

${ }^{71}$ Cf. GHIRON, Mario. Corso di Diritto Industriale, volume primo, seconda edizione riveduta ed ampliata, Roma: 1935, p. 222

${ }^{72}$ Op. cit., p. 359
} 
a) A primeira delas diz respeito à atribuição de direitos e obrigações à pessoa a que pertence, ainda que indiretamente ${ }^{73}$ (como nos casos de mandatários ${ }^{74}$ ).

b) A segunda função refere-se à captação de clientela, ou seja, o nome é um instrumento para atrair e conservar a clientela, de modo a manter a empresa. Assim, o nome pode ser empregado, como meio coletor geral de clientela, de todas as formas possíveis em relação à atividade, seja para identificar a casa matriz e suas filiais, seja em material publicitário etc.

GHIRON alude, ainda, a uma terceira função exercida pelo nome: elemento de validade de certos atos jurídicos. Neste caso, o nome funcionaria como elemento essencial da forma, que a lei exige para a validade de determinado ato jurídico. É o que chama de nome-forma ${ }^{75}$.

Concordamos com GHIRON, pois em havendo erro substancial quanto à identidade da pessoa a quem se refira à declaração de vontade, desde que tenha influído nesta de modo relevante, o negócio jurídico pode ser anulado ${ }^{76}$. O nome é, assim, elemento essencial à validade de atos jurídicos.

\section{Diferenças entre o nome civil e o nome de empresa}

Em termos gerais, a palavra nome está relacionada, usualmente, à denominação que a lei assegura a um sujeito de direito, para fazer-se reconhecido e obrigar-se em suas relações jurídicas. Contudo, existem substanciais diferenças entre o nome civil e o nome empresarial, as quais merecem especial atenção:

a) Quanto à sua formação, pois, por se tratar de direito absoluto, o nome empresarial, seja nome de empresário, razão social ou denominação de fantasia, deve ser novo (pois há liberdade de escolha), ao passo que é permitida a homonimia entre nomes civis.

b) Quanto à possibilidade de modificação, uma vez que, diferentemente do que ocorre, em regra, com o nome civil, o nome de empresa pode ser modificado, ainda que com certas limitações no caso das firmas e razões sociais.

\footnotetext{
${ }^{73}$ É o que GHIRON denomina de nome-titolo d'imputazione (op. cit. p. 224)

${ }^{74} \mathrm{Cf}$. art. 653, do CC, opera-se o mandato quando alguém recebe de outrem poderes para, em seu nome, praticar atos ou administrar interesses. Sempre que o mandatário estipular negócios expressamente em nome do mandante, será este o único responsável

${ }^{75}$ Cf. GHIRON, Mario. Op. cit. p. 224

${ }^{76}$ Nesse sentido, vide arts. 138 e 139 , inc. II, do CC
} 
c) Quanto à economicidade, já que o nome de empresa possui valor econômico, sendo o nome civil inestimável.

d) Quanto à inalienabilidade, já que, embora a regra geral seja da vedação da cessão, em certos $\operatorname{casos}^{77}$, o nome de empresa pode ser alienado, ao contrário do nome civil que é inegociável.

e) Quanto à extinção do direito, uma vez que o nome de empresa pode ser cancelado quando cessar o exercício da atividade para a qual foi adotado, ou quando se ultimar a liquidação da sociedade que o inscreveu ${ }^{78}$, ao passo que o nome civil é imprescritível.

f) Quanto ao sujeito, conquanto o nome de empresa identifique seu titular no exercício da empresa, o nome civil individualiza a pessoa em si mesma considerada.

g) Quanto à extensão da proteção, os nomes civis devem gozar de proteção erga omnes, uma vez que espelham a personalidade da pessoa. Por seu turno, como veremos ao longo deste estudo, a proteção ao nome de empresa tem contornos e limites próprios e que são determinados pela forma de utilização do nome.

O nome de empresa pode ser usado, por seu titular, de formas diversas: (i) pode ser aposto nos produtos, de maneira similar às marcas, servindo, pois, para distinguir os produtos de um empresário em relação aos seus concorrentes; (ii) mais comumente, o nome empresarial não é empregado nos produtos como se marca fosse, mas apenas nos papéis relacionados à atividade, tais como: notas fiscais, faturas, material publicitário, catálogos etc.; (iii) o nome de empresa pode ser usado, ainda, na fachada do estabelecimento comercial.

\footnotetext{
${ }^{77}$ V. Cap. II, no 8 infra.

${ }^{78}$ Cf. art. 1.168 , do CC.
} 


\section{Capítulo II \\ O NOME DE EMPRESA}

\section{Os sinais distintivos do empresário}

Os direitos industriais dividem-se, basicamente, em invenções industriais e sinais distintivos. Para este estudo, interessando-nos apenas os sinais distintivos, que são definidos, na lição de PAUL MATHELY, “comme étant des moyens phonétiques ou visuels, particulièrment des mots ou des images, qui sont appliqués, dans la vie économique et sociale, à la désignation des personnes ou des entreprises, ainsi que des produits ou services que'elles fournissent, afin de les distinguer et de permettre au public de les reconnaître" 79 .

São considerados sinais distintivos quaisquer combinações de palavras e/ou figuras utilizadas no exercício da atividade empresarial para identificar o próprio empresário ou sociedade empresária (nomes de empresa), o estabelecimento comercial (títulos de estabelecimento e insígnias ou signum tabernae), os produtos e serviços (marcas), a propaganda (sinais ou expressões de propaganda) e os endereços na Internet (nomes de domínio).

Temos, portanto, que:

a) Marca é o sinal, visualmente perceptível ou não ${ }^{80}$, que tem por finalidade identificar, distinguir e certificar produtos e serviços de outros produtos e serviços de origem diversa em um mesmo ramo de atividade;

b) Título de estabelecimento é sinal nominativo que identifica o estabelecimento empresarial $^{81}$;

\footnotetext{
${ }^{79}$ MathÉLy, Paul. Le Droit Français des Signes Distinctifs, Paris: Librairie du Jornal des Notaires et des Avocats, 1984, p. 03

${ }^{80}$ Observe-se que a LPI exigiu, como condição para registro de marca que os sinais sejam visualmente perceptíveis (art. 122), exercendo a faculdade prevista no art. 15, $\mathrm{n}^{\circ} 1$, in fine, do TRIPs.

${ }^{81} \mathrm{O}$ registro dos títulos de estabelecimento foi extinto pelo art. 119, da Lei $\mathrm{n}^{\circ}$ 5.772/1971, sendo protegido, atualmente, pelas normas de repressão à concorrência desleal. Não concordamos com TINOCO SOARES que vislumbrou a possibilidade de proteção dos títulos de estabelecimento objeto de proteção perante as Juntas Comerciais. Segundo o autor "se partirmos do princípio de que toda modificação, alteração ou transformação de uma empresa e bem assim as mudanças de sócios, de sede e outras são objeto de inscrição na Junta Comercial, também aquelas relativas aos 'nomes de estabelecimento' devem ocorrer" (Novo Código Civil: pessoas jurídicas, empresário, sociedade, estabelecimento, nome comercial e/ou empresarial, perdas e danos e prescrição. Revista da ABPI, $n^{\circ} 58$, mai./jun. 2.002, p. 54). A nosso ver, no bojo do contrato social poderá ser citado o título de estabelecimento que será usado pelo empresário, ou, ainda, aquele que passou a ser usado. Ao nome de empresa, decerto, poderá ser agregada expressão designativa da atividade, se convier ao empresário ou para diferenciá-lo de outro já existente, o que não constitui título de estabelecimento. Para
} 
c) Insígnia, ou signum tabernae, é o dístico que identifica o estabelecimento empresarial;

d) Sinal ou Expressão de Propaganda é a legenda, anúncio, reclame, palavra, combinação de palavras, desenhos, gravuras, originais e característicos que se destinem a emprego como meio de recomendar quaisquer atividades lícitas, realçar qualidade de produtos, mercadorias ou serviços, ou a atrair a atenção dos consumidores ou usuários;

e) Nome de domínio sinal que identifica o empresário ou o estabelecimento em ambiente virtual ${ }^{82}$.

Cada um dos sinais distintivos usados pelo empresário no exercício da empresa possui proteção própria e específica, decorrente da função individualizadora exercida em uma situação de concorrência ${ }^{83}$. Contudo, a proteção conferida a cada um destes instrumentos de identificação do empresário é interdependente, tendo o objetivo fundamental de elidir confusão no mercado. Em outras palavras, os sinais distintivos estão interligados, de modo que, v.g., uma expressão usada como elemento característico de um nome de empresa não pode ser adotada como marca ou título de estabelecimento de outrem e vice-versa ${ }^{84-85}$, evitando-se, dessarte, a concorrência desleal. Como disse SAINT-GAL: “a

proteção do título de estabelecimento, com supedâneo na regra cardinal de repressão à concorrência desleal, deverão ser levadas em consideração as circunstâncias de fato, de modo que sua previsão no contrato social é interessante meio de prova de uso, mas não constitui direito ou proteção per si.

${ }^{82}$ Há discussão na doutrina e jurisprudência quanto ser o nome de domínio sinal distintivo autônomo ou mera projeção da marca, título de estabelecimento ou nome de empresa na Internet. Vide: SILVEIRA, Newton. A propriedade intelectual na Internet e a questão dos nomes de domínio, Revista de Direito Mercantil, São Paulo: Revista dos Tribunais, ano 29, nº 119, p.26-33, jul./set. 2000, p. 26-33; TINOCO SOARES, José Carlos. Abuso de direito pelo uso de nomes de domínio na Internet, Revista dos Tribunais, $\mathrm{n}^{\circ}$ 786, p. 68-76, abr. 2001, p. 68-76; LABRUNIE, Jacques. Conflitos entre nomes de domínio e outros sinais distintivos, Direito \& Internet: aspectos jurídicos relevantes, Bauru: Edipro, 2000, p. 239-256; JABUR, Wilson Pinheiro. Nome de Domínio: Novo Sinal Distintivo?, in Propriedade Intelectual: sinais distintivos e tutela judicial e administrativa, Coord. Wilson Pinheiro Jabur e Manoel J. Pereira dos Santos. São Paulo: Saraiva, 2007, p. 267-309; ESTEVES, Luciana Batista. A ICANN e a regulamentação dos nomes de domínio. Revista da ABPI, $\mathrm{n}^{\mathrm{o}} 79$, nov./dez. 2005

${ }^{83}$ Cf. SilveIRA, Newton. Licença de uso de marca e outros sinais distintivos, cit., p. 15

${ }^{84}$ No dizer de Luiz LEONARDOS: "é irrelevante que a marca tenha por fim assinalar mercadorias ou produtos, que o título de estabelecimento distinga o próprio estabelecimento comercial e que o nome comercial identifique o comerciante, porquanto a utilização de elemento caracterizador comum trará inevitável confusão" (in Apreciação do conflito entre marcas e nomes comerciais, Revista da ABPI, São Paulo: vol. 41, jul./ago. 1999, p. 37). Vide também: PINHEIRO, Waldemar. Do conflito entre nome comercial e marca. Revista da ABPI, São Paulo, vol. 31, nov./dez. 1997, p.24; e SCHMIDT, Lélio Denicoli. Princípios aplicáveis aos sinais distintivos, in Propriedade Intelectual: sinais distintivos e tutela judicial e administrativa, Coord. Wilson Pinheiro Jabur e Manoel J. Pereira dos Santos. São Paulo: Saraiva, 2007, p. 42/43

85 "Assim sendo", diz Newton SILVEIRA, "como elemento identificadores da atividade 'aziendal', todos os sinais usados pelo empresário devem receber a mesma tutela contra a concorrência desleal, independentemente de sua especialização em signos do empresário, do estabelecimento ou do produto ou serviço" (in Licença do uso da marca e outros sinais distintivos, cit., p. 15) 
noção da concorrência desleal constitui ao mesmo tempo a soma e o complemento de toda a regulamentação sobre os direitos de propriedade industrial" ${ }^{86-87}$.

O nome de empresa, objeto deste estudo, faz parte do aviamento subjetivo do empresário, pois ligado à sua pessoa, ao passo que o título de estabelecimento, insígnia, marca, expressões de propaganda e nomes de domínio compõem seu aviamento objetivo (aziendal).

Estas considerações iniciais, que permitem diferenciar o nome de empresa de outros sinais distintivos e revelam que o direito de propriedade industrial reconhece a possibilidade de proteção de um bem imaterial gozar de proteção sob dois ou até mais regimes distintos ${ }^{88}$, eram de grande importância, para possibilitar melhor intelecção do nome de empresa.

\section{A questão da nomenclatura}

Antes de adentrarmos ao estudo do nome de empresa, há uma questão de ordem que deve ser enfrentada: as diversas nomenclaturas atualmente usadas no ordenamento jurídico em relação ao nome adotado pelo empresário ${ }^{89}$. A pergunta que se impõe é: nome comercial, nome de empresa e nome empresarial são sinônimos?

O que se pode, a priori, constatar é que todas as denominações usam sempre o vocábulo nome, mas empregam expressões diversas para compô-las, o que acaba, como veremos, dando-lhes significação e conteúdo diferentes.

\subsection{Nome comercial}

Desde as mais vetustas referências, que remontam ao surgimento do Direito Comercial, cunhou-se a expressão nome comercial para identificar o nome adotado pelo comerciante no exercício da atividade comercial. A razão é histórica.

\footnotetext{
${ }^{86}$ SAINT-GAL, Yves. Concurrence Déloyale et Concurrence Parasitaire, in Revue Internationale de la Propriété Industrielle et Artistique, 1956, n 25/26, p. 20, apud LEONARDOS, Luiz. Apreciação do conflito entre marcas e nomes comerciais. In Revista da ABPI, nº 41, jul./ago. 1999

${ }^{87}$ No mesmo sentido, GAMA CERQUEIRA definia propriedade industrial como sendo "o conjunto dos institutos jurídicos que têm por fim prevenir e reprimir a concorrência desleal no comércio e na indústria" (in Tratado da Propriedade Industrial, cit. vol. 1, p. 79)

${ }^{88}$ Cf. Gabriel F. LEONARDOS, A proteção ao nome empresarial, cit., p. 135

${ }^{89}$ V.g. a Constitução Federal de 1988 fala em nome de empresa (art. 5º XIX); a Lei de Registro Público de Empresas Mercantis refere-se a "nome empresarial"; a Lei da Propriedade Industrial alude ao "nome de empresa" (art. 124, inc. V) e também ao nome comercial (art. 195, V); o Código Civil e, também na Lei de Falência e Recuperação de Empresas, há referência ao "nome empresarial”.
} 
Nos primórdios do Direito Comercial ${ }^{90}$, era considerado comerciante somente aquele matriculado em uma corporação de ofício, ou seja, o critério para determinar se uma pessoa era comerciante era subjetivo ${ }^{91}$.

Neste momento, o direito comercial apresenta-se como um direito profissional, produto de uma etapa histórica determinada, situado ao lado do direito comum tradicional (civil), também por circunstâncias e exigências históricas que vão acompanhar a sua evolução, posto que sempre o resultado de um conjunto de fatores econômicos e políticosociais $^{92}$.

Posteriormente, baseado nos ideais de liberdade e igualdade que permearam a Revolução Industrial Inglesa e a Revolução Francesa, surge o Código Comercial Francês em 1807 (conhecido como Code Napoléon) ${ }^{93}$, adotando a tendência objetiva do direito comercial, não mais considerando o direito dos comerciantes corporativistas, mas o direito dos atos de comércio, enumerados pela lei. Este Código Francês serviu de paradigma para o conceito de mercancia adotado pela Lei $\mathrm{n}^{\circ} 556$, de 25 de junho de 1850, que instituiu o Código Comercial Brasileiro, e pelo Regulamento 737, de 25 de novembro de 1850. Logo, eram considerados comerciantes aqueles que praticassem atos de comércio e do seu exercício fizessem profissão habitual.

Segundo o art. 19, do Regulamento 737, consideravam-se atos de mercancia a compra e venda e troca de efeitos móveis ou semoventes, para vender por grosso ou retalho, na mesma espécie ou manufaturados, ou para alugar o seu uso; as operações de câmbio, banco e corretagem; as empresas de fábricas, de comissão de depósito, de expedição, consignação e transportes de mercadoria, de espetáculos públicos; os seguros, fretamentos, riscos e quaisquer contratos relativos ao comércio marítimo e à armação e expedição de navios.

Em se tratando de Direito Comercial, aplicável apenas aos comerciantes, assim tidos aqueles que prativacam, com habitualidade, atos de comércio, era natural que o nome

\footnotetext{
${ }^{90}$ Notadamente entre os séculos XII e XVI.

${ }^{91}$ Com o florescimento das corporações de ofício e de seus estatutos próprios originou uma dicotomia de jurisdições, coexistindo os tribunais dos mercadores e os comuns. O critério de determinação da competência destes tribunais especiais era subjetivo, em um primeiro momento somente àqueles que participassem das corporações e, posteriormente, em razão da qualidade de sujeito (mercatore), àqueles que praticassem atos do comércio.

${ }_{92}$ FrANCO, Vera Helena de Mello. Manual de Direito Comercial, vol. 1: o empresário e seus auxiliares, o estabelecimento empresarial, as sociedade, $2^{a}$ ed. rev., atual. e ampl., São Paulo: Revista dos Tribunais, 2004, p. 21

${ }^{93}$ Como ensina VerÇosA “os Tribunais de Comércio, responsáveis pela aplicação do Código Comercial Francês, nos termos do art. 631, tinham competência para conhecer as causas relativas aos "negociantes,
} 
que o comerciante adotava no exercício de sua atividade fosse denominado de nome comercial.

Essa expressão consolidou-se no Direito e difundiu-se, passando a ser largamente usada no ordenamento jurídico e doutrina dos mais diversos países, assim como nos tratados internacionais sobre propriedade industrial ${ }^{94}$.

Constata-se, do até agora exposto, que o nome comercial sempre esteve ligado à atividade comercial, ou seja, as normas que o tutelam são aquelas de natureza comercial e, por conseguinte, as de propriedade industrial.

Nesse sentido, e veremos ao longo deste estudo, as normas aplicáveis ao nome comercial são específicas (Constituição Federal, Convenção da União de Paris e a Lei da Propriedade Industrial) e, assim, diferentes daquelas aplicadas ao nome empresarial tido como aquele pertinente ao Registro Público.

\subsection{Nome de empresa}

O Direito Comercial, como sabemos, surgiu da necessidade prática dos comerciantes, para quem o direito romano (que estava sendo redescoberto) não bastava para (a) atribuir um maior grau de segurança e de previsibilidade às relações comerciais e (b) proteger a celeridade e outras peculiaridades da vida mercantil ${ }^{95}$.

A evolução do direito comercial está, portanto, vinculada ao próprio desenvolvimento econômico. Miguel Reale ensina que o direito é um fenômeno histórico-social, sempre sujeito a variações e intercorrências, fluxos e refluxos no espaço e no tempo ${ }^{96}$. Isso porque as sociedades, no seu desenvolvimento, tendem à especialização de atividades, como identificam os problemas mais diversos a serem submetidos ao direito $^{97}$. Da mesma forma, as transformações que ocorrem na economia têm relevância fundamental para o sistema jurídico. É a partir delas que se pode compreender a forma de variação das estruturas jurídicas ${ }^{98}$.

mercadores e banqueiros', aos sócios nas questões relativas às sociedades comerciais; aos atos de comércio em relação a todas as pessoas, sendo possível o recurso a árbitros" (Curso de Direito Comercial 1, cit. p. 43)

${ }^{94}$ V., nesse sentido, o art. $8^{\circ}$ da CUP, de 1883.

${ }^{95}$ FORGIONI, Paula A. Op. cit., p. 18

${ }^{96}$ REALE, Miguel. Lições preliminares de direito, $23^{\text {a }}$ edição, São Paulo: Saraiva, 1996, p. 14

${ }^{97}$ Lotufo, Renan. Curso avançado de Direito Civil, vol. 1, Parte Geral, (coord. Everaldo Augusto Cambler), São Paulo: Revista dos Tribunais, 2002, p. 21

${ }^{98}$ CAMPILONGO, Celso Fernandes. Política, sistema jurídico e decisão judicial, São Paulo: Max Limonad, 2002, p. 89 
Ocorre que a teoria dos atos do comércio mostrou-se, ao longo do tempo, insuficiente e limitada, pois afastava da incidência das normas comerciais os nãocomerciantes: os empresários agrícolas, os entes públicos e quem exercesse atividade não comercial, como os profissionais intelectuais.

Surge, então, o Código Civil italiano de 1942 que unificou o Direito Privado naquele país, justificando-se que diversos campos tinham a mesma disciplina, como, v.g., o direito das obrigações e dos contratos. A forma e os princípios do Código Civil italiano, como a adoção da Teoria da Empresa, influenciaram definitivamente o nosso Código Civil de 2002, o qual chega a ponto de reproduzir integralmente diversos dispositivos.

Com a unificação do direito privado, máxime do direito das obrigações, rompeu-se com a dicotomia, até então existente, entre o Direito Comercial e o Direito Civil ${ }^{99}$. Dentro deste escopo de unificação, foram realizadas importantes alterações em nosso ordenamento jurídico, corporificando entre nós uma das mais importantes características do direito comercial moderno, notadamente a adoção da teoria da empresa, já maturada no exterior, abandonando a teoria dos atos de comércio consagrada no código revogado.

Assim, foi introduzida em nosso ordenamento jurídico positivo a teoria da empresa, de origem italiana, em detrimento da já não mais adequada teoria dos atos de comércio, consagrada no Code Napoléon de 1807. Vale dizer que nossa legislação já vinha paulatina e timidamente incorporando esta tendência, como se pode observar, p.ex. na Lei de Abuso de Poder Econômico de $1962^{100}$ e na Consolidação das Leis do Trabalho (arts. $2^{\circ}$ e 448).

De mesma forma, a expressão nome comercial foi sendo substituída por nome de empresa, conforme se verifica no Código da Propriedade Industrial de 1967 (Decreto-Lei

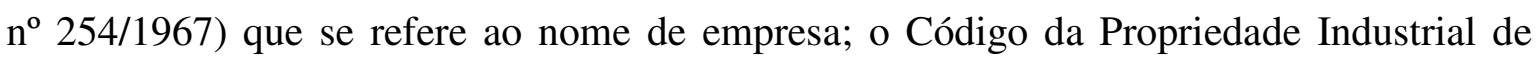
1971 (Lei $n^{\circ}$ 5.772/1971) fazia menção ora ao nome comercial, ora ao nome de empresa; na Constituição Federal de 1988 que alude ao nome de empresa (art. 5º, XXIX).

Sobre a questão, DENIS BORGES BARBOSA diz que "ao incluir a última expressão no texto da proposta que veio a tornar-se o Art. $5^{\circ}$. XXIX da Carta de 1988, estava consciente de ferir uma longa tradição do nosso sistema jurídico, e dos textos internacionais pertinentes; mas pareceu-lhe adequado subscrever à parcela da doutrina nacional que, atenta à prevalência do setor serviços na economia moderna, e da especificidade da noção de empresa, em face da noção de pessoa jurídica, prefere fazer tutelar não só as firmas,

\footnotetext{
${ }^{99}$ Sobre a introdução do direito de empresas no CC e a unificação dos direitos das obrigações, vide nosso artigo "Introdução do direito de empresas no novo Código Civil. A unificação do direito das obrigações, in Revista de Direito Empresarial, Curitiba, no 9, jan./jun. 2008, p. 153-174
} 
denominações e nomes de sociedades comerciais, mas também os correlativos das sociedades civis de fins econômicos e mesmo o nome comercial do empreendimento individual" 101.

A substituição da expressão nome comercial por nome de empresa representa muito mais que mera alteração adjetiva, traduzindo-se em um verdadeiro alargamento de significância e incidência. É dizer, nome de empresa não é mero sinônimo de nome comercial. Desta forma, sob a expressão nomes de empresa "englobam-se todas as designações utilizadas por entes econômicos, civis ou comerciais, personalizados ou não, de forma a individualizar, através de um símbolo de nominação, sua posição na concorrência" ${ }^{102}$.

Assim, até o advento do CC, os nomes de pessoas jurídicas de direito civil tinham regime que não se confundia com o dos nomes de empresa. A proteção daqueles derivava do registro da pessoa jurídica no Registro Público Mercantil.

Portanto, o mérito da adoção da expressão nome de empresa consiste na equiparação, para os efeitos da proteção da lei, a denominação das sociedades simples, associações e fundações.

\subsection{Nome empresarial}

A expressão nome empresarial deriva, obviamente, do "nome de empresa" e já se encontra difundida em nosso ordenamento jurídico, como na Lei de Registro Público de Empresas Mercantis (Lei no 8934, de 18 de novembro de 1994) que expressamente referese ao "nome empresarial"; no Código Civil (Lei n 10.406, de 10 de janeiro de 2002) e, também na Lei de Falência e Recuperação de Empresas (Lei no 11.101, de 05 de fevereiro de 2005) em cujo art. 69 há referência ao "nome empresarial”.

Conforme reza o art. 1.155 do Código Civil "considera-se nome empresarial a firma ou a denominação adotada para o exercício de empresa", estendendo-se a proteção à denominação das sociedades simples, associações e fundações (art. 1.155, § único). Temos, portanto, que o nome empresarial vincula-se à pessoa do empresário ou da sociedade empresária.

\footnotetext{
${ }^{100}$ Lei $\mathrm{n}^{\mathrm{o}} 4.137$, de 10 de setembro de 1.962 .

${ }^{101}$ BARBOSA, Denis Borges. Uma introdução à propriedade intelectual, cit. p. 930.

${ }^{102}$ Ibidem, p. 926.
} 
O Código Civil, assim como o paradigma italiano, não define empresa, mas apenas empresário, como sendo aquele que exerce profissionalmente atividade econômica organizada para a produção ou a circulação de bens ou de serviços ${ }^{103}$.

Note-se que a lei alude, também, ao "não empresário", prevendo no parágrafo único do art. 966, que: "não se considera empresário quem exerce profissão intelectual, de natureza científica, literária ou artística, ainda com o concurso de auxiliares ou colaboradores, salvo se o exercício da profissão constituir elemento de empresa".

Assim, tendo em vista o disposto no parágrafo único do aludido art. 966, basta que seja exercida, de forma estável, habitual e organizada, a atividade negocial para que se enquadre na condição de empresário, podendo, inclusive, incluir a atividade intelectual.

O CC louva-se dos conhecidos perfis de ASQUINI ${ }^{104}$, especialmente quanto ao perfil subjetivo, considerando empresa, nesse passo, não quanto ao modo de exercício da propriedade pelo titular, mas sim sob o prisma do próprio titular e das condições que deve satisfazer, a fim de realizar, juridicamente, o empreendimento econômico.

No mais, à semelhança do modelo italiano, o Código Civil brasileiro prende-se à figura do empresário, individual e social, sujeito de direitos e obrigações resultantes do exercício da empresa (perfil subjetivo), ao estabelecimento (aziendal), ou seja, ao complexo de bens organizados pelo empresário para o exercício de sua atividade empreendedora (perfil objetivo), e à atividade econômica organizada para a produção ou a circulação de bens ou de serviços exercida profissionalmente pelo empresário (perfil funcional) ${ }^{105}$.

Vimos, assim, que a expressão nome empresarial não é sinônimo de nome comercial, possuindo significado e conteúdo diverso. Enquanto o nome comercial está ligado ao perfil funcional, e assim sua tutela dá-se pelas normas de concorrência (previstas na legislação de propriedade industrial), o nome empresarial encontra-se relacionado ao perfil subjetivo, nos termos do Código Civil e das normas que cuidam do Registro Público Mercantil.

A nosso ver, portanto, nome comercial e nome empresarial têm significados diferentes, mas englobados dentre de um conceito maior de nome de empresa. Nome de

\footnotetext{
${ }^{103}$ Cf. art. 966, do CC.

${ }^{104}$ V. ASQUINI, Alberto. Perfis da empresa (Profili dell'impresa. Rivista del Diritto Commerciale 41, I. 1943). Trad. De Fábio Konder Comparato. Revista de Direito Mercantil, Industrial, Econômico e Financeiro, v. 35, n. 104, p. 109-126, out./dez. 1996

${ }^{105}$ Há no CC um único artigo que se refere aos três perfis da empresa, a saber: o art. 1.142, segundo o qual se considera estabelecimento todo complexo de bens organizado, para exercício da empresa, por empresário, ou por sociedade empresária
} 
empresa é, portanto, gênero das espécies nome comercial e nome empresarial. O primeiro (nome comercial) está ligado à função objetiva do nome (função econômicoconcorrencial), como elemento que caracteriza, individualiza e distingue a atividade do empresário, pessoa física ou jurídica, no campo da concorrência. Por seu turno, o segundo (nome empresarial) reflete a função subjetiva do nome (função identificadora), pois tem o encargo apenas de designar o sujeito de direitos e obrigações. Desta forma, podemos dizer que a adoção do nome comercial é facultativa, ao passo que o nome empresarial é uma obrigação do empresário e sociedade empresária.

\section{Conceito do nome comercial}

A legislação brasileira, desde o Decreto 916, de 24 de outubro de 1890, sempre procurou fixar o conceito de firma, sistemática mantida com o vigente Código Civil, definindo, em seu art. 1.155, que se considera nome empresarial a firma ou a denominação adotada para o exercício de empresa.

Não obstante a clareza legislativa, alguns doutrinadores ${ }^{106}$ procuraram ampliar o conceito de nome comercial, de modo que abarcasse outros sinais distintivos do empresário, como a insígnia (emblema ou sinal figurativo que identifica o estabelecimento comercial) e o título de estabelecimento (dístico ou sinal nominativo, distinto da firma ou denominação, que identifica o estabelecimento).

Nesse diapasão afinava-se a definição de BENTO DE FARIA, para o qual "por nome comercial ou industrial entende-se, de modo geral, ora a denominação patronímica de um comerciante ou fabricante, ora o nome do lugar em que o produto foi fabricado, e finalmente também a própria designação dada a esses produtos, ou a estabelecimento comercial. Vulgarmente, porém, o nome comercial é aquele sob o qual um estabelecimento comercial ou industrial é conhecido do público, e especialmente da clientela" ${ }^{107}$.

Para GAMA CERQUEIRA, que distinguiu duas funções exercidas pelo nome, o nome comercial "em sua verdadeira acepção, compreende não só o nome do comerciante, pessoa física ou jurídica, como também, a denominação (ou insígnia) do estabelecimento, o nome dos produtos e dos lugares de produção e quaisquer outros elementos ligados ao complexo

\footnotetext{
${ }^{106}$ Como Barreto Filho, Bento de Faria, Rotondi e GAMA CERQueIRA

107 BENTO DE FARIA, Antonio. Das marcas de fabrica e de commercio e do nome commercial. Rio de Janeiro: J. Ribeiro dos Santos, 1906, p. 284
} 
do estabelecimento, que distingam ou individualizem o comerciante ou as suas atividades"

Outros, como AFFONSO CELSO, restringiram sobremaneira o conceito, confundindoo com título de estabelecimento ${ }^{109}$.

Contudo, como bem acentuou LUIZ LeONARdos "o conceito restrito é o que prevalece na doutrina, na legislação e na jurisprudência brasileira para o nome comercial, nele não se incluindo além da 'denominação sob a qual exerce alguém o gênero da indústria e comércio a que se dedica', outros elementos designativos da atividade comercial, como o título do estabelecimento e a insígnia, objetos de conceituação e regulamentação próprios" ${ }^{110-111-112}$.

Esta ampliação indevida do conceito de nome comercial deu-se pela confusão em que incorreram alguns doutrinadores entre o nome comercial e outros sinais distintivos usados pelo empresário no exercício de sua atividade, para identificar seus produtos ou serviços (marca), estabelecimento comercial (título de estabelecimento e insígnia) ou para indicar o local de procedência do produto (indicações geográficas). O conjunto destes sinais distintivos forma a azienda ou fundo de comércio do empresário, mas cada qual possui proteção própria e diferenciada, conforme bem explicitado por CARVALHO DE MENDONÇA: "o nome comercial é a expressão mais ampla pela firma ou razão comercial, quando, porém, o nome comercial (ou a firma ou razão) é empregado pelo comerciante como insígnia do seu negócio ou estabelecimento ou como marca de comércio, cada um dêsses usos tem função especial e produz resultados diversos. $\mathrm{O}$ nome comercial ou a firma servindo de insígnia ou de marca de comércio não é mais o sinal que individualiza o comerciante, sujeito de direito, com seu patrimônio e suas obrigações, porém, constitui, uma coisa, objeto de direito. São diversas nesses casos as disciplinas jurídicas. Quando se

\footnotetext{
${ }^{108}$ Importante ressaltar que GAMA CERQUEIRA considerava que o nome comercial, em sua função objetiva, visa proteger a própria atividade da empresa, seu aviamento, abarcando, desta forma, não só a firma e denominação, mas o pseudônimo do comerciante, as alcunhas dadas pelo público, a insígnia, marca, produto, nome da localidade e sua notoriedade. Daí a extensão de sua definição.

${ }^{109}$ CELSO, Affonso. Marcas industriaes e nome commercial. cit., $\mathrm{n}^{\mathbf{0}} 109$

${ }_{110}^{110}$ A proteção ao nome comercial no Direito Brasileiro, in RT 450/25-31

${ }^{111}$ GAMA CERQUEIRA, embora propugnasse por um conceito mais ambrangente, admitia que "a tendência de nossos mais autorizados escritores se manifesta no sentido de restringir o conceito do nome comericial ao nome sob o qual o comerciante ou industrial, pessoa física ou jurídica, exerce seu comércio ou indústria" (in Tratado da Propriedade Industrial, cit., p. 461).

${ }^{112}$ SOLIDÔNEO LEITE negava o alcance do nome comercial aos emblemas, mas o admitia para o título de estabelecimento (op. cit., p. 26)
} 
compõe a marca de comércio com o nome do comerciante, não é o nome que se tutela, é a marca de comércio" 113 .

A nosso ver, a melhor definição de nome comercial foi-nos dada por PONTES DE MiRANDA, segundo o qual "no sistema jurídico brasileiro, o nome comercial é o nome da pessoa física ou jurídica, para o exercício de atividades comerciais, industriais ou agrícolas" ${ }^{114-115}$. Esta sucinta e precisa definição, vanguardista para a época em que se ainda aplicava a teoria dos atos do comércio, estendeu o conceito àqueles que exercessem atividades agrícolas e, portanto, não comerciais.

Hodiernamente, podemos definir nome empresarial como sendo a firma ou a denominação adotada pela pessoa física ou jurídica, para o exercício de sua atividade empresarial, a qual é, conforme exegese do art. 966, do CC, a atividade econômica organizada para a produção ou a circulação de bens ou de serviços, aí não se incluindo as profissões intelectuais, de natureza científica, literária ou artística ${ }^{116}$.

Para Denis Borges BARBosA “[s]ob a expressão, consagrada constitucionalmente, de nomes de empresa englobam-se todas as designações utilizadas por entes econômicos, civis ou comerciais, personalizados ou não, de forma a individualizar, através de um símbolo de nominação, sua posição na concorrência" 117 .

Não nos parece correta a definição de DENIS BORGES BARBOSA, pois trata indistintamente do nome empresarial tanto em sua função identificadora, quanto em sua função econômico-concorrencial. Decerto o nome empresarial tem o condão de identificar, individualizar o empresário ou sociedade empresária, mas não apenas tendo em vista sua posição na concorrência. O elemento concorrência pode nem existir, sendo o nome empresarial tão-só sinal identificador, decorrente da obrigatoriedade de individualizar-se como sujeito de direitos e obrigações.

Portanto, a definição de BARBOSA aplica-se apenas ao nome comercial objetivo, ou seja, aquele pertencente aos domínios da Propriedade Industrial, excluindo, quiçá por

\footnotetext{
${ }^{113}$ MendonçA, José Xavier Carvalho de. Op. cit., p. 151

${ }^{114}$ PonTES DE MIRANDA. Tratado de Direito Privado, Parte Especial, $4^{\mathrm{a}}$ ed. São Paulo: Revista dos Tribunais, 1983 , t. XVI, p. 222

${ }^{115}$ Merece menção, outrossim, a definição de SOLIDÔNEO LEITE, segundo a qual "o nome commercial (signal da reunião da clientela, thermometro do credito, segundo CALMELS; pavilhão da mercadoria, no dizer de POUILLET; meio de concurrencia de freguezes, na phrase de GASTAMBIDE) póde definir-se: aquelle com que se distinguem as pessoas e sociedades, que exercem um commercio, ou os seus estabelecimentos" (op. cit., p. 22)

${ }^{116}$ O DNRC, através da IN n ${ }^{\circ} 99$, de 21 de dezembro de 2005, define nome empresarial como sendo aquele sob o qual o empresário e a sociedade empresária exercem suas atividades e se obrigam nos atos a elas pertinentes

${ }^{117}$ In Uma introdução à propriedade intelectual, cit., p.926
} 
opção do referido autor, o nome empresarial subjetivo, i.e., aquele com função meramente identificadora.

A proteção conferida ao nome empresarial do empresário e das sociedades empresárias aplica-se também à denominação das sociedades simples, associações e fundações, conforme expressamente dispõe o parágrafo único do art. 1.155 do Código Civil. JoÃo MARCoS SILVEIRA critica a equiparação, para fins de proteção, pois entende que "por não se dedicarem a atividades econômicas com finalidade lucrativa, não merecem as sociedades simples, as associações e as fundações tutela de seus nomes como 'sinal de trabalho', isto é, em seu aspecto objetivo - o que não significa que não gozem de direitos exclusivos sobre seus nomes, haja vista que, considerados em sua função de 'sinal de identidade', em seu aspecto objetivo, tais direitos decorrem, ipso iure, da simples constituição de sua personalidade jurídica, já tendo sido reconhecidos em diversas instâncias por nossas cortes" ${ }^{118-119}$.

Manifestando-se acerca de equiparação similar feita pelo Decreto-lei $\mathrm{n}^{\circ}$ 7.903/45, em seu art. 104, asseverou KARIN GRAU-KUNTZ que “[s]e a intenção do legislador foi louvável, no sentido de conceder proteção explícita ao nome das associações e fundações, pecou-se pelo desnecessário ao buscar fazê-lo valendo-se da legislação de caráter concorrencial. Como já demonstramos, as fundações e associações têm seus nomes protegidos em caráter exclusivo pelo simples fato destes sinais reportarem a suas identidades. Não exercendo atividade empresarial as associações e fundações não gozarão de proteção concorrencial" ${ }^{120}$.

Para nós é extremamente salutar a equiparação ao nome empresarial, para fins de proteção, da denominação das sociedades simples, associações e fundações ${ }^{121}$, pois o “não-comerciante, pessoa física ou jurídica, ainda fundação, pode alegar usurpação o qualquer dano, ainda se só moral o interesse" ${ }^{122}$. Evidentemente, a proteção reserva-se à função identificadora (subjetiva), visto que, por não exercerem atividades empresariais,

\footnotetext{
${ }^{118}$ SILVEIRA, João Marcos. O nome empresarial no novo Código Civil. RDM no 128, 2.002, p. 132

${ }^{119}$ A nosso ver, a crítica de JOÃo MARCOS SILVEIRA parte de uma falsa premissa, especialmente em relação às sociedades simples. Isso porque as sociedades simples possuem finalidade lucrativa, diferenciando-se das empresárias apenas na forma com que exploram seu objeto, ou seja, do modo pelo qual a atividade econômica é exercida. Outra é a situação das associações e fundações, as quais exercem uma atividade econômica, mas com fins não econômicos. Quer isso dizer que a atividade econômica é exercida como meio e não como finalidade, pois o lucro deve ser revertido integralmente à atividade, não sendo distribuído aos associados.

${ }^{120}$ GRAU-KunTZ, Karin. Do nome das pessoas jurídicas, São Paulo: Malheiros Editores, 1998, p. 55

${ }^{121}$ Opinião compartilhada por MAURO ARRUDA (in Considerações sobre a proteção jurídica do nome comercial, em face do projeto do novo Código Civil, RDM no 113 , jan./mar. 1.999)

${ }^{122}$ PONTES DE MiRANDA, Francisco Cavalcanti. Op. cit., t. XVI, p. 224
} 
não haverá proteção concorrencial inerente à função objetiva do nome comercial. Esta distinção quanto ao alcance da proteção à denominação das sociedades simples, associações e fundações é de grande relevância, pois exclui a aplicação em relação a tais entes associativos de normas de conteúdo comercial, como, v.g., as instruções normativas do DNRC e a Lei da Propriedade Industrial ${ }^{123}$.

\section{Modalidades de nome empresarial}

Embora alguns doutrinadores incluam entre as modalidades de nome empresarial a insígnia, o título de estabelecimento, a localidade de produção e, até mesmo, a marca, a nosso ver, a interpretação deve ser restritiva. Cada um destes elementos ou bens imateriais, que compõe a azienda do empresário, possui proteção própria e independente do nome empresarial, não devendo com ele ser confundidos.

Não obstante a louvável intenção de alguns doutrinadores em proteger toda a atividade empresarial através do nome comercial, é certo que tais institutos já se encontram, cada qual, devidamente protegidos através das normas repressivas da concorrência desleal (que assegura proteção inclusive aos sinais distintivos não registrados), sendo certo que alguns possuem disciplina jurídica própria, como as marcas registradas, os desenhos industriais, as indicações geográficas que gozam de tutela diferenciada.

Ocorre que o empresário, ao usar o nome empresarial no âmbito de suas atividades empresariais, ou seja, no campo da concorrência, normalmente não o utiliza integralmente, abrevia-o ou adota somente o elemento nuclear, diferenciador, principalmente em se tratando de denominações, o que acaba por transmutá-lo em marca ou título de estabelecimento. Todavia, o nome empresarial remanesce e goza de proteção própria, assim como a marca e o título de estabelecimento que possa constituir.

\footnotetext{
${ }^{123}$ Nesse sentido já se manifestou o STJ: PESSOA JURÍDICA. ASSOCIAÇÕES (RELIGIOSAS). NOMES (PROTEÇÃO). REGISTRO (ANTECEDÊNCIA). PRECEITO COMINATÓRIO (IMPROCEDÊNCIA). 1. Formal e materialmente, não há norma que proteja nome de associação destinada a desenvolver atividade religiosa; de fins, portanto, não econômicos. Inaplicabilidade do Cód. de Prop. Industrial, ainda que sob as luzes dos arts. $4^{\circ}$ da Lei de Introdução e 126 do CPC. 2. Regência do caso pelos arts. 114, I e 115 da Lei no 6.015/73. 3. Não há meios jurídicos que garantam a propriedade do nome religioso, "podendo ser ostentado, pronunciado, venerado e adotado por quantos seguidores e/ou cultores tenha ou venha a ter, individualmente ou organizados em associações" (acórdão estadual), haja vista o que ordinariamente acontece com as igrejas cristãs pelo mundo afora. 4. Recurso especial fundado na alínea a, de que a Turma não conheceu. (STJ, $3^{\mathrm{a}}$ T., REsp 66.529/SP, Rel. Min. Nilson Naves, j. em 21.09.1999, DJ 19.06.2000, p. 138)
} 
Entendemos, portanto, que o nome empresarial é gênero do qual são espécies a firma e a denominação, as quais, assim como o nome civil, têm a função de identificar o empresário $^{124}$.

\subsection{A firma}

Inicialmente, importante esclarecer que firma não é sinônimo de empresa, seja esta considerada uma atividade, sociedade ou estabelecimento. O emprego do termo firma nestas condições mostra-se totalmente incorreto e atécnico, pois firma é tão-somente uma das modalidades de nome empresarial.

Existem em nosso ordenamento jurídico duas espécies de firma: a firma individual e a firma social, também chamada de razão social.

Firma é, assim, "o nome sob o qual os comerciantes singulares ou as sociedades comerciais, em que há sócios de responsabilidade, exercem o comércio e se assinam nos atos a estes referentes". Sob ela "o negociante exerce a sua profissão, entra em relações com o público, assina-se nos atos relativos ao seu negócio, especifica, determina e responsabiliza o seu patrimônio, comparece ativa e passivamente, nos tribunais" ${ }^{125}$.

A firma deverá sempre ser constituída pelo nome civil do empresário ou de pelo menos um deles no caso de sociedade, não sendo permitidos nomes de terceiros, em atenção ao chamado princípio da veracidade, “con una razón de interes público, dada la función distintiva del nombre comercial" ${ }^{126}$.

De acordo, ainda, com o princípio da veracidade, o nome de sócio que vier a falecer, for excluído ou se retirar, não pode ser conservado na firma social. Assim, esclarece CARVALHO DE MENDONÇA, que "[n]ão é permitido ao comerciante tomar outro nome que não seja o próprio para constituir sua firma. Logo, os pseudônimos (nom de plume), apelidos, alcunhas, hipocorísticos etc. não podem constituir firma. Tem o comerciante que exerce singularmente o comércio, a faculdade de aditar à firma, designação mais precisa da sua pessoa ou do gênero de comércio" 127-128.

\footnotetext{
${ }^{124}$ Nesse sentido, CARVALHO DE MENDONÇA assinalava que “[o] sentido da expressão nome comercial é, como se observa, mais amplo do que o da fórmula firma ou razão comercial. O nome comercial compreende tanto a firma ou razão comercial, da qual sòmente podem usar os comerciantes singulares e as sociedades de responsabilidade ilimitada, como a designação das sociedades anônimas. Êle é gênero, as outras duas as espécies" (Tratado de Direito Comercial Brasileiro, cit., p. 145)

${ }^{125}$ MendonçA, José Xavier Carvalho de. Op. cit, no 176

${ }^{126}$ ASCARELLI, Tullio. Op, cit. p. 369

${ }^{127}$ MendonçA, José Xavier Carvalho de. Op. cit., p. 163

${ }^{128}$ V. art. 1.156, do CC
} 
Ademais, como conseqüência de sua função identificadora, as firmas devem ser dotadas de eficácia distintiva em relação às demais. Veremos adiante o grau de novidade exigido na comparação entre firmas, mas o certo é que, a rigor, não poderão coexistir firmas idênticas.

\subsubsection{Firma individual}

Trata-se, a firma, da mais antiga modalidade de nome empresarial, pois era comum no início do tráfico mercantil que os comerciantes adotassem seu próprio nome para exercer suas atividades comerciais e identificar seus produtos ${ }^{129}$.

Nos termos do art. 1.156 do Código Civil, o empresário individual opera sob firma constituída por seu nome, completo ou abreviado, aditando-lhe, se quiser, designação mais precisa da sua pessoa ou do gênero de atividade ${ }^{130}$. Assim, a firma deve necessariamente corresponder ao nome civil do empresário, completo ou abreviado, sendo que este compreende o prenome e o patronímico, sob pena de vulnerar o princípio da veracidade ${ }^{131}$.

Se desejar, ou se vier a ser necessário para fins de diferenciação com empresário homônimo, deverá ser acrescentada designação mais precisa de sua pessoa ou do gênero de atividade que exerce ${ }^{132-133}$. Salienta-se que o empresário individual não tem personalidade jurídica $^{134}$. As obrigações contraídas sob a firma comercial ligam a pessoa civil do comerciante e vice-versa ${ }^{135}$.

\subsubsection{Firma ou razão social}

Por seu turno, a firma ou razão social é formada pelo nome de um ou mais sócios. Como ensinou CARVAlHo DE MENDONÇA: "[s]e a pessoa exerce a profissão mercantil, nessa esfera de atividade individualiza-se e assinala o seu patrimônio e as suas

\footnotetext{
${ }^{129} \mathrm{O}$ nome comercial é historicamente anterior às marcas. No início do tráfico mercantil os comerciantes usavam seus nomes comerciais para identificar a procedência dos produtos.

${ }^{130}$ Redação similar à do art. $3^{\circ}$, caput, do Decreto 916, de 24 de outubro de 1890

131 Com o prenome, o nome ou o sobrenome, isoladamente, ou conjugados, a firma comercial se forma, necessariamente, lecionou WALDEMAR FERREIRA (in Tratado de Direito Comercial, São Paulo: Saraiva, 1962, sexto volume, 172).

${ }^{132}$ Cf. VerçosA. Haroldo Malheiros Duclerc. Curso de Direito Comercial , cit, p. 257

${ }^{133}$ Neste sentido o parágrafo único, do art. 1.163, do CC: Art. 1.163. O nome de empresário deve distinguirse de qualquer outro já inscrito no mesmo registro. Parágrafo único. Se o empresário tiver nome idêntico ao de outros já inscritos, deverá acrescentar designação que o distinga

${ }^{134}$ Há apenas uma equiparação para finalidade tributária.

${ }^{135}$ MENDONÇA, José Xavier Carvalho de. Op. cit., p. 167
} 
responsabilidades pelo seu nome comercial. O nome dos comerciantes singulares (pessoas naturais) e das sociedades onde existem sócios de responsabilidade ilimitada enuncia-se, na linguagem técnico-jurídica, pelo vocábulo firma ou razão social" ${ }^{, 136}$.

$\mathrm{Na}$ firma social os nomes dos sócios poderão figurar de forma completa ou abreviada, admitida a supressão de prenomes, assim como o aditivo "e companhia" ou "\& Cia.” poderá ser substituído por expressão equivalente, tal como "e filhos" ou "e irmãos", dentre outras.

Algumas sociedades devem obrigatoriamente ter firma. As sociedades em que houver sócios de responsabilidade ilimitada operarão necessariamente sob firma, na qual somente os nomes daqueles poderão figurar, bastando para formá-la aditar ao nome de um deles a expressão "e companhia" ou sua abreviatura ${ }^{137}$.

Logo, nas sociedades em que os sócios respondem solidária e ilimitadamente pelas obrigações contraídas, deve ser adotada firma, como as sociedades em nome coletivo ${ }^{138}$, as sociedades em comandita simples ${ }^{139}$ e as sociedades em comandita por ações ${ }^{140}$.

Como bem salientou VERÇOSA, “[m]esmo que, pelo contrato social, certas pessoas não sejam sócios de responsabilidade solidária e ilimitada, caso seu nome venha a fazer parte da firma social ou razão social, eles passarão a estar sujeitos àquela forma de responsabilidade. Isto porque dá-se a entender a terceiros, com quem a sociedade venha a fazer negócios, que ela conta com o patrimônio de todos os que constam de seu nome empresarial para o pagamento de suas obrigações, em caráter subsidiário" ${ }^{141}$.

Vale dizer, que é vedado às sociedades anônimas o uso de firma, devendo identificar-se, necessariamente por denominação ${ }^{142}$, como veremos adiante.

\footnotetext{
${ }^{136}$ Ibidem, p. 144

${ }^{137}$ Cf. art. 1.157, do CC

${ }^{138}$ Ressaltando que "sem prejuízo da responsabilidade perante terceiros, podem os sócios, no ato constitutivo, ou por unânime convenção posterior, limitar entre si a responsabilidade de cada um" (art. 1.039, parágrafo único, do $\mathrm{CC}$ )

${ }^{139}$ Diferentemente do Decreto 916 que trazia disposição expressa (art. $3^{\circ}$, § $2^{\circ}$ ), o Código Civil não tem regra expressa quanto à firma das sociedades em comandita simples. Contudo, o art. 1.046 reza que se aplicam à sociedade em comandita simples as normas da sociedade em nome coletivo, no que forem compatíveis, de tal sorte que tendo os sócios comanditados, necessariamente pessoas físicas, responsabilidade solidariedade e ilimitada e sendo vedada a inclusão na firma dos sócios comanditários (art. 1.047), a firma deverá ter necessariamente o nome de um ou mais sócios comanditados, com o aditamento por extenso ou abreviado da expressão "e Companhia" caso não individualize todos os sócios.

${ }^{140}$ As sociedades em comandita por ações poderão constituir-se com firma ou denominação. Podem, desta forma, adotar firma ou razão social, da qual só farão parte os nomes dos sócios-diretores ou gerentes com o aditivo "e Companhia". Ficam ilimitada e solidariamente responsáveis pelas obrigações sociais, os que, por seus nomes, figurarem na firma ou razão social. A denominação ou a firma deve ser seguida das palavras “Comandita por Ações", por extenso ou abreviadamente (art. 281 da Lei n 6.404, de 15 de dezembro de 1976)

${ }^{141}$ VERÇOSA. Haroldo Malheiros Duclerc. Curso de Direito Comercial, cit., p. 258

${ }^{142}$ Cf. art. 1.160, do CC. V. ainda art. $3^{\circ}$ da Lei ${ }^{\circ} 6.404 / 1976$
} 
As sociedades limitadas, por seu turno, podem adotar firma ou denominação, integradas pela palavra final "limitada", ou pela sua abreviatura, cuja omissão resultará na responsabilidade solidária e ilimitada dos administradores ${ }^{143}$. Se adotarem firma, esta deverá ser composta com o nome de um ou mais sócios, desde que pessoas físicas, de modo indicativo da relação social. No caso de denominação, deverá designar o objeto da sociedade, sendo permitido nela figurar o nome de um ou mais sócios.

Como dito, algumas sociedades poderão adotar, ao invés da firma, denominação. Em suma, firma é o nome utilizado pelo empresário, pela sociedade em que houver sócio de responsabilidade ilimitada e, de forma facultativa, pela sociedade limitada e denominação é o nome utilizado pela sociedade anônima e cooperativa e, em caráter opcional, pela sociedade limitada e em comandita por ações.

\subsection{Denominação}

Denominação é todo o nome ou locução aleatória apropriada pelo empresário para designação de sua empresa. A denominação tanto pode ser constituída do próprio nome do empresário, como de outro nome arbitrário ou de fantasia ${ }^{144}$.

A denominação é formada com palavras de uso comum ou vulgar na língua nacional ou estrangeira e/ou com expressões de fantasia, com a indicação do objeto da sociedade $^{145}$. As denominações devem ser distintas das demais; não devem ser ilícitas, i.e. contrárias à lei, à ordem pública e aos bons costumes; não devem ser deceptivas, ou seja, suscetíveis de induzir em erro a clientela quanto às características e qualidades do empresário; e, finalmente, devem consistir em sinais arbitrários e de fantasia, podendo possuir sinais genéricos ou necessários ${ }^{146}$.

O uso da denominação, como dito, é facultativo na sociedade limitada, devendo sempre ser seguida da palavra "limitada", por extenso ou abreviada e nas comanditas por ações, em que deverá ser seguida da expressão "em comandita por ações”, por extenso ou abreviada. A denominação é obrigatória nas sociedades anônimas e nas cooperativas.

\footnotetext{
${ }^{143}$ Cf. art. 1.158, do CC

${ }^{144}$ LEITE, Augusto. O nome commercial, São Paulo: s.n., 1916, p. 71

${ }^{145}$ Vale dizer que as denominações, em sua gênese, estritamente ligadas às sociedades anônimas que eram autorizadas a funcionar pelo Imperador, eram formadas exclusivamente por expressão designativa de seu objeto social, pois não se acreditava que haveria capital para a constituição de outra sociedade anônima para a mesma atividade.

${ }^{146}$ Em sentido contrário, v. RoubIER, Paul. Le Droit de la Propriété Industrielle, cit., p. 689
} 


\section{Princípios gerais aplicados às firmas e denominações}

Das observações feitas quanto às modalidades de nome empresarial, extraímos que a formação das firmas e denominações deve obedecer a dois princípios básicos: o princípio da veracidade e o princípio da novidade ${ }^{147}$.

\subsection{Princípio da veracidade}

De acordo com o princípio da veracidade, os elementos componentes das firmas e denominações devem ser verdadeiros e não induzir em erro sobre a identificação, natureza ou atividades do seu titular ${ }^{148}$.

Assim, a firma deverá sempre ser constituída pelo nome civil do empresário ou de pelo menos um deles no caso de sociedade, não sendo permitidos nomes de terceiros. Da mesma forma, o nome de sócio que vier a falecer, for excluído ou se retirar, não pode ser conservado na firma social (art. 1.165, do CC).

Este dever de veracidade impõe a alteração da firma quando o nome civil do empresário tenha sido alterado, o que pode ocorrer em razão de casamento, divórcio, ou seja, em todos os casos que a lei autorize. Outrossim, se a firma contiver designação mais precisa da pessoa ou do gênero de atividade do empresário e houver alteração quanto a estes, a firma deverá ser igualmente modificada.

\subsection{Princípio da novidade}

Já o princípio da novidade, que decorre da função identificadora, impõe, basicamente, que a firma e a denominação devem ser distintas daquelas adotadas previamente por outros empresários (art. 1.163, do CC).

A necessária diferenciação entre as firmas e denominações visa elidir qualquer confusão, não só em relação aos consumidores, mas a todos os demais agentes de mercado que possam, de alguma forma, relacionarem-se com o empresário, tais como: fornecedores, instituições de crédito, bancos etc. Desta forma, temos que o princípio da novidade vige inclusive em se tratando de ramos de atividade diverso.

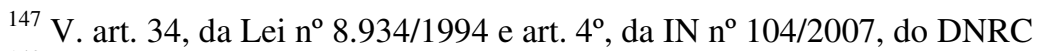

${ }^{148}$ Cf. Olavo, Carlos. Propriedade Industrial, vol. I, $2^{\text {a }}$ ed. actual., rev. e aumentada. Coimbra: Almedina, 2005 , p. 200
} 
Veremos, ao estudarmos, no Cap. V infra, os critérios de colidência entre as diversas modalidades de nomes empresariais, que o grau de novidade exigido entre as firmas e denominações difere, tendo em vista as regras de formação de uma e outra.

\section{A dupla função do nome empresarial}

Mister se faz, antes de adentrar a discussão quanto à natureza do nome empresarial, distinguir as diferentes funções por ele exercidas, que influenciaram, como veremos adiante, as teorias sobre sua natureza jurídica. O nome empresarial, como dito, constitui sinal distintivo do empresário, identificando-o como sujeito de direitos e obrigações, podendo, ainda, distingui-lo de seus concorrentes caso seja usado no exercício de sua atividade econômica.

ROUBIER divisou as duas diferentes funções do nome empresarial, destacando que "[l] théorie du nom commercial a été quelque peu obscurcie dans notre droit, du fait que le nom se présente sous deux formes distinctes: a) Dans une première forme, le nom commercial sous lequel un commerçant pratiquera le commerce et signera ses engagements (...) b) Dans une seconde forme, le vocable choisi pour désigner une entreprise commerciale ne remplit pas le rôle de signature; il a seulement un but de réclame et de propagande pour attirer l'attention du public" ${ }^{149}$.

No Brasil, também explicitando as diferentes funções exercidas pelo nome comercial, Almeida NogueIRA destacou que o nome empresarial tem dois sentidos - o lato e o restrito. "Neste, é o nome do comerciante, individual ou coletivo, pessoa natural ou jurídica. Designa naquele o estabelecimento mercantil ou industrial, se não a localidade de proveniência dos produtos ou mercadorias" ${ }^{150}$.

Exerce, assim, duas funções diferentes: a primeira subjetiva, de individualização do empresário e a segunda, chamada objetiva, relacionada ao exercício da atividade econômica $^{151}$.

Com sua peculiar clareza, ASCARELLI ensinou que "al lado del nombre comercial (subjetivo) que individualiza al empresário, del (objetivo) que individualizaría a la

\footnotetext{
${ }^{149}$ ROUBIER, Paul. Op. cit., p. 662

${ }^{150}$ FERREIRA, Waldemar. Op. cit., p. 177

${ }^{151}$ No dizer de GHIRON: "[t]rattando invece la ditta come bene immateriale si incide nel vivo del nostro instituto; se ne separa un parte avente carattere oggettivo da un'altra avente carattere suggettivo; si inquadra la prima nella teoria generale delle cose, la seconda nella teoria dei diritti soggettivi" (Corso di Diritto Industriale, p. 268). Na função objetiva, diz GHIRON, a lei atribui-lhe um regime de exclusiva, a fim de que possa executar sua função de coletor de clientela (op. cit., p. 267).
} 
empresa”. Salienta ASCARELLI que "[p]recisamente porque identifica al empresario, el nombre comercial cumple aquella función que hemos denominado de colector de clientela con respecto a la individualización de la persona del empresario y, por tanto, al ejercicio de su actividad (....) "el nombre comercial, por su composición, se presta mejor a la difusión, a la publicidad, al conocimiento, al reclamo y a servir de cordón umbilical entre la clientela y el empresario, identificando, así, a éste frente a aquélla" ${ }^{152-153 .}$

Quanto à distinção entre nome comercial subjetivo e objetivo, manifestou-se RoTONDI: "[m] a il Rocco che profila la distinzione non dice poi quale sia il criterio per distinguere la ditta oggettiva dalla soggettiva, che in mancanza di altra determinazione si sarebbe tentati di fare risiedere, con evidente petizione di principio, nell'identità o meno della ditta col nome del titolare dell'azienda. È per questo che, pur avendo adottata un'analoga distinzione a proposito dell'avviamento per una deficienza del nostro lessico (avviamento reale o oggetivo e personale o soggetivo) - crediamo meglio qui, dove a designare il nome del titolare dell'azienda possiamo valerci senz'altro delle formule 'nome', 'ragione' o 'denominazione sociale', riservare la qualifica di ditta per designare quella che è vera denominazione non del titolare, ma dell'azienda e definirla appunto come 'denominazione dell' azienda commerciale", 154.

Na esteira da lição de ASCARELli, GAMA CERQueIRA asseverou que "a adoção de firma ou denominação impõe-se pela necessidade de saber com quem se trata e contrata e a quem competem as responsabilidades assumidas e, no caso das sociedades, quais as pessoas que por elas também se obrigam. Sob esse aspecto, o nome do comerciante individual, as firmas e denominações ligam-se estreitamente à pessoa do comerciante, como o nome civil à personalidade de quem o usa. No mundo dos negócios e nas relações com terceiros exercem, precipuamente, a função de designar o sujeito de direito. É a função subjetiva do nome. Sob outro aspecto, porém, as firmas sociais e as denominações das sociedades anônimas, a firma ou denominação das sociedades por quotas, como a firma do comerciante singular, exercem função objetiva, que caracteriza, individualiza e distingue a atividade do comerciante ou industrial, pessoa física ou jurídica, no campo da competência comercial. Nessa função, mais importante sob o nosso ponto de vista, as firmas e denominações entram no domínio da propriedade industrial e ficam sujeitas a

\footnotetext{
${ }^{152}$ AsCARELLI, Tullio. Op. cit., p. 361

${ }^{153}$ ASCARELLI, em sua obra, refere-se ao nome comercial como sendo a firma individual do empresário, aludindo à razão social (para sociedade de pessoas) ou denominação social (para sociedades de capital) para as pessoas jurídicas ou coletividades organizadas (v.g. associações e fundações)

${ }^{154}$ Rotondi, Mario. Diritto Industriale. IV ed., Milão: Casa Editrice Ambrosiana, 1942, p. 70
} 
regime especial e a princípios diversos, gozando, ao mesmo tempo, da extensa proteção das leis e princípios que disciplinam a concorrência comercial. Já aqui a adoção de uma firma ou denominação aparece como um direito e não como uma imposição legal. A firma ou denominação converte-se num bem jurídico de valor patrimonial, cuja defesa constitui também um direito. Dupla função, portanto, subjetiva e objetiva, exercem as firmas e denominações, como simples designação da pessoa física ou jurídica, como sujeito de direitos e termo de obrigações comerciais, e como projeção da individualidade do comerciante singular ou da universalidade do estabelecimento comercial no campo da concorrência" ${ }^{155-156}$.

Por seu turno, GRAU-KUNTZ, também reconhecendo as duas funções exercidas pelo nome empresarial, propõe uma nomenclatura diferente: "na primeira hipótese o sinal exerce função de 'sinal de identidade', e o conteúdo que representa, a identidade, é um direito decorrente da concessão de personalidade à pessoa jurídica, cujas regras de formação e proteção encontram-se nas normas de direito comercial. Na segunda hipótese o sinal exerce função de 'sinal de trabalho', cujo conteúdo protegido é o trabalho como instrumento dotado de valor econômico, cuja proteção é tema de direito concorrencial”" 157 .

DI FRANCO preferiu denominá-las de função identificadora e função distintiva do nome empresarial ${ }^{158}$.

Em suma, o nome empresarial, em um primeiro momento, exerce uma função subjetiva, constituindo um sinal de identificação do empresário, como sujeito de direito e obrigações dentro da generalidade dos atos inerentes à sua atividade, a que preferimos chamar de função identificadora.

De outro lado, exerce o nome empresarial uma função objetiva, distinguindo seu titular de seus concorrentes no âmbito das atividades econômicas, ou seja, no campo da

\footnotetext{
155 Gama CerqueIRA, João da. Tratado da Propriedade Industrial, v. 1, cit., p. 471/472

${ }^{156}$ Ainda sobre a dupla função exercida pelo nome empresarial, cita-se: FRAN MARTINS "o nome comercial, seja firma ou denominação, tem um dúplice significado em relação ao comerciante. Em primeiro lugar, é o nome com que o mesmo assina o exercício de suas atividades, servindo assim, para identificá-lo. Visto sob esse prisma, o nome comercial equivale ao nome civil da pessoa física e constitui um direito personalíssimo do comerciante (...) Visto sob outro aspecto, o nome comercial, firma ou denominação, pode qualificar também a empresa comercial. Nesse caso, adquire um valor patrimonial, maior ou menor, segundo o conceito em que é tida a empresa. Deixa de ser simples identidade para se converter em um bem incorpóreo, que se agrega ao acervo patrimonial do comerciante como parte da universalidade de coisas que constitui o seu fundo de comércio" (in Curso de Direito Comercial. Rio de Janeiro: Forense, p. 490); e, ainda, PHILOMENO J. DA COSTA "registra-se então que o nome civil é um direito da personalidade do cidadão e que o nome comercial é igualmente um direito da personalidade do (...) empresário (chamado ainda, com algum atraso no tempo, de comerciante). Têm-se então os dois campos de proteção em matéria de nomes. Um é de sujeitos dentro da generalidade. Outro é de sujeito dentro das atividades econômicas" (in Comentários, RDM n 81, p. 96-107, jan.-mar./91)

${ }^{157}$ GRAU-KUNTZ, Karin. Do nome das pessoas jurídicas, cit., p. 27
} 
concorrência, função esta que preferimos chamar de econômico-concorrencial. Esta proposta de nomenclatura tem por escopo alumiar, de forma clara, o valor econômico que o nome empresarial adquire no campo comercial ${ }^{159}$, assim como os limites de sua proteção, como veremos no momento oportuno.

Sobre a função objetiva do nome empresarial, ensina NEWTON SILVEIRA que: "no caso do empresário, o nome ou sinal pelo qual é conhecido no comércio (não só pela clientela, mas pela generalidade dos agentes que atuam no comércio, como fornecedores, instituições de crédito, distribuidores etc.) integra seu aviamento subjetivo, diretamente ligado à pessoa (natural ou jurídica), ao qual se agrega o conceito público de que desfrute esta" 160 .

Esta função consiste em faculdade do titular do nome empresarial (direito subjetivo exclusivo, nas palavras de NEWTON SILVEIRA ${ }^{161}$ ), podendo ser formado pela firma ou denominação, ou por qualquer outro sinal distintivo pelo qual o empresário seja identificado no exercício de suas atividades.

A dicotomia entre as funções exercidas pelo nome empresarial também se verifica no campo legislativo, visto que, enquanto sinal de trabalho, usado como cordão umbilical entre a clientela e o empresário, sua tutela dá-se, atualmente, pela Constituição Federal de 1988, pela Lei da Propriedade Industrial, pela Convenção da União de Paris e pelo Código de Defesa do Consumidor. Já o nome empresarial, como sinal identificador do empresário ou sociedade empresária (função subjetiva), é regido pela Lei de Registro Público de Empresas Mercantis e pelo Código Civil.

\section{Natureza jurídica do nome empresarial}

A natureza jurídica do nome empresarial é, há muito, controvertida na doutrina e jurisprudência $^{162}$. Em síntese, três são as principais teorias sobre a natureza do nome

\footnotetext{
${ }^{158}$ Di FranCO, Luigi. Trattato della Proprietà Industriale, cit., p. 355

${ }^{159}$ Nesta função, estabelece-se o direito de exploração do valor que o nome se criou e esse valor é patrimonial, disse PONTES DE MIRANDA (op. cit., p. 231).

${ }_{160}$ In Licença de uso de marca e outros sinais distintivos, cit., p. 10

${ }^{161}$ In Licença de uso de marca e outros sinais distintivos, cit., 11

${ }^{162}$ ROUBIER, por exemplo, trata da natureza do nome empresarial também como direito público, pois " $[e] n$ réalité il n'y a guère de droit au nom. Le nom est une de ces situations juridiques entièrement objectives, comme il em existe tant em droit public: on n'a pas seulement le droit de porter son nom, on en a aussi l'obligation " (Le Droit de la Propriété Industrielle, cit., p. 669). Segundo ele, toda pessoa ou grupo de pessoas que vai empreender um comércio está sujeito pelo direito comercial a uma primeira obrigação, que é justamente de declarar sua firma e o local de sua sede, por ocasião do registro de seus atos constitutivos no registro do comércio (op. cit., p. 670).
} 
empresarial: teoria do nome empresarial como direito da personalidade; teoria do nome empresarial como direito de propriedade; e teoria do nome empresarial na esfera concorrencial.

\subsection{O nome empresarial como direito da personalidade}

A primeira teoria considera o nome empresarial como elemento da personalidade do empresário, constituindo um direito extrapatrimonial qualificado como um direito de personalidade, tal qual o direito à integridade física, à honra e à imagem.

Segundo esta teoria, tem-se o nome empresarial, nas palavras de WALDEMAR FERREIRA, "como direito personalíssimo do dono do estabelecimento" 163-164-165, ou seja, a expressão da personalidade do empresário exteriorizada no campo comercial.

Como salientou Pontes DE MiRAnda, "há o direito de personalidade ao nome, como há os outros direitos de personalidade" ${ }^{166}$. Seu fundamento deriva do fato que, ensina ROUBIER, "leurs titulaires peuvent avoir un intérêt particulièrement vif à défendre contre les usurpations : ces noms de famille représentent souvent une valeur précieuse, un élément important de l'état des personnes; aussi les actions qui tendent à la protection du nom des personnes doivent-elles être classées dans le groupe des actions d'état" 167-168.

Esta corrente é diametralmente oposta àquela que defende o direito de propriedade ao nome empresarial, e fundamenta-se na inalienabilidade e imprescritibilidade pelo não uso do nome empresarial. Para seus defensores, há somente distinção de conteúdo entre o nome civil e o nome empresarial, de maneira que a função de designar a personalidade é idêntica ${ }^{169}$.

\footnotetext{
${ }^{163}$ FERREIRA, Waldemar. Tratado de Direito Comercial, São Paulo: Saraiva, 1962, sexto vol., p. 175

${ }^{164}$ GAMA CERQUEIRA informa que no exterior foi Kohler que desenvolveu de modo mais completo esta teoria, classificando o direito ao nome empresarial, à marca e à insígnia entre os direitos individuais (Individualrechte), ao lado dos direitos imateriais, que compreendem as criações artísticas e industriais (op. cit, vol. 1, pp. 477/478)

${ }^{165}$ Comungam deste entendimento, ainda, GRAU-KUNTZ: "daí podermos dizer que o direito ao nome das pessoas jurídicas é um dos direitos decorrentes da personalidade jurídica" (op. cit., p. 21) e JoÃo MARCOS SILVEIRA: "o nome, antes de mais nada, como sinal identificador da pessoa, seja natural ou jurídica, consiste em um direito inato e intrinsecamente relacionado à personalidade" (op. cit., p. 123).

${ }^{166}$ PONTES DE MIRANDA, Francisco Cavalcanti. Op. cit., t. XVI, p. 222/223

${ }^{167}$ ROUBIER, Paul. Op. cit., p. 671

${ }^{168}$ Por esta razão, afimava PONTES DE MIRANDA, que "[a] a firma social e a denominação da pessoa jurídica têm a mesma proteção que a firma individual; e tôdas, a mesma proteção do nome civil, seja da pessoa jurídica, seja da pessoa física" (op. cit., p. 241)

${ }^{169}$ Para VeRÇOSA, "[d]o ponto de vista da natureza jurídica do nome de empresa, o Código Civil/2002, na esteira do melhor entendimento doutrinário anterior, afastou-a claramente da propriedade ao proibir que seja objeto de alienação (art. 1.164, caput). Representa o nome empresarial, da mesma forma que o nome civil, pura emanação do direito de personalidade" (op. cit., p. 256)
} 
Este entendimento permeou as disposições do Código Civil, cujo art. 52 determina que às pessoas jurídicas aplica-se, no que couber, a proteção dos direitos da personalidade, dentre os quais se encontra o direito ao nome ${ }^{170}$.

GAMA CERQUeIRA critica esta teoria, aduzindo que "quanto ao nome comercial, parece-nos igualmente frágil essa construção teórica, cujos princípios só poderiam ter aplicação ao caso dos comerciantes individuais, em que o nome comercial coincide com o nome civil da pessoa. Não se ajustariam esses princípios aos nomes comerciais compostos de outros elementos, às firmas e denominações que designam sociedades e ás insígnias distintivas dos estabelecimentos comerciais" ${ }^{171-172}$.

\subsection{O nome empresarial como direito de propriedade}

Para a segunda corrente, influenciada pela jurisprudência francesa do fim do século XIX, o nome empresarial seria um direito de propriedade de seu titular, a exemplo do que ocorre com as marcas ${ }^{173}$. Para RoUBIER o nome empresarial, como bem incorpóreo, seria oponível como direito real, pois fundamentado no valor que representa como instrumento de ligação entre a clientela e o fundo de comércio. Segundo o autor francês: "le nom est un signe de ralliement de la clientèle, comme la marque de fabrique ; les bénéfices qu'il est susceptible d'assurer, au milieu de la concurrence, par le rappel d'un nom connu du public et apprécié par lui, constituent l'élement qui permet de mesurer l'importance de ce droit" ${ }^{174}$.

Nesse sentido, AlmeIDA NogUEIRA e FISCHER entendiam que o nome comercial é uma propriedade, por vezes de alto valor econômico, tanto para a indústria como para o comércio $^{175}$. AFFONSO CELSO ${ }^{176}$ e BENTO DE FARIA ${ }^{177}$ também consideravam o nome

\footnotetext{
${ }^{170}$ Cf. art. 16 , do CC

${ }^{171}$ Op. cit., p. 1.167

${ }^{172}$ ROUBIER, analisando o direito francês e o alemão, esclareceu que: "[e]n droit français, on ne protège le nom commercial que contre un emploi dans des commerces ou industries similaires, parce que c'est là seulement qu'on peut redouter une concurrence effective et un détournement de clientèle. Mais le droit allemand n'envisage pas les choses sous l'angle de l'entreprise d'une manière aussi exclusive; il admet qu'une firme peut avoir intérêt à ne pas être confondue avec une firme identique, même dans in autre commerce, si cette firme est de réputation douteuse; l'action peut être engagée sur la base d'un intérêt moral, même en intérêt de famile ou d'affection, comme lorsqu'il s'agit en France du nom civil de la personne" (op. cit., p. 672)

${ }^{173}$ A LPI brasileira, em seu art. $5^{\circ}$, reza que se consideram bens móveis, para os efeitos legais, os direitos de propriedade industrial

${ }_{174}$ ROUBIER, Paul. Op. cit., p. 674

175 ALMEIDA NoGUEIRA, J. L. de \& FISHER JÚNIOR, Guilherme. Tratado theórico e prático de marcas industriaes e nome commercial. São Paulo, Typ. Hennies Irmãos, 1910, Vol. 1, n. 528

${ }^{176}$ CELSO, Affonso. Marcas Industriais, cit., p., 102/103
} 
comercial como um direito de propriedade, assim como SPENCER VAMPRÉ, para o qual “o nome comercial constitue uma verdadeira propriedade industrial" ${ }^{178}$.

Mais recentemente, JosÉ CARLOS TINOCO SOARES, manifestou-se no sentido de que a Constituição da República Federativa do Brasil de 1988 “de maneira iniludível consagra e assegura a PROPRIEDADE das marcas e aos NOMES DE EMPRESA" ${ }^{179}$.

Nesta teoria, a propriedade do nome empresarial assegura ao seu titular o direito de insurgir-se contra todo e qualquer uso indevido, ainda que de boa-fé, e sem que se tenha que comprovar qualquer dano ou prejuízo. Bastaria para sua proteção apenas a comprovação da propriedade do nome empresarial, sem qualquer outra justificativa ${ }^{180}$.

GAMA CERQUEIRA, maior tratadista pátrio nesta matéria, tinha-o como um direito de propriedade imaterial. Dizia ele: "o direito sôbre o nome comercial constitui uma propriedade em tudo idêntica a das marcas de fábrica e de comércio, que se exerce sôbre uma coisa incorpórea, imaterial, exterior à pessoa do comerciante ou industrial, e encontra seu fundamento no direito natural do homem aos resultados de seu trabalho. Essa propriedade abrange não só o nome do comerciante singular, como também a firma das sociedades em nome coletivo, as denominações das sociedades anônimas e por quotas, a insígnia dos estabelecimentos e os demais elementos que entram no conceito do nome comercial, considerados como objetos autônomos do direito" ${ }^{181}$.

A principal crítica que se faz a esta corrente é que a estrutura do direito de propriedade dá-se em função de um bem corpóreo, não sendo plenamente possível sua aplicação no tocante aos bens incorpóreos, demandando certas adaptações e/ou limitações. Por exemplo: não se pode ceder isoladamente o nome empresarial, mas somente acompanhado do fundo de comércio que identifica.

Ainda, a rigor, não se pode evitar o uso de nome comercial idêntico, caso não haja uma relação de concorrência.

\footnotetext{
${ }^{177}$ Bento de FARIA, Antonio. Op. cit., p. 304 e ss.

${ }^{178}$ VAMPRÉ, Spencer. Do nome civil: sua origem e significação sociologica; teorias que explicam; suas alterações; direitos e deveres correlativos, Rio de Janeiro: Brighiet, 1935, p. 44

${ }^{179}$ in Marcas vs. nome comercial: conflitos, São Paulo: Jurídica Brasileira, 2000, p. 201

${ }^{180}$ PONTES DE MIRANDA critica tal entendimento, aduzindo que "[o] nome é bem jurídico, porém não bem que possa ser tido como objeto de direito real (já assim, excelente, A. RAMELLA, Trattato della Proprietà Industriale, II, n. 555 s.)" (op. cit., p. 230)
} 


\subsection{O nome empresarial como direito pessoal (ou obrigacional)}

A terceira corrente tem o nome empresarial como um direito pessoal ${ }^{182}$ do empresário, cujo principal defensor no Brasil, seguindo a teoria de KOHLER, era CARvalho de Mendonça. Para este comercialista, o nome do comerciante não é propriedade, mas sim um direito meramente pessoal ${ }^{183-184}$, porquanto não tem valor comercial, inestimabilis res est, e, assim: a) não figura no ativo do balanço da casa comercial; é inalienável e intransmissível, porque é inerente à pessoa e não pode ser considerado distintamente deste, pelo que não pode ser objeto de contrato, nem pode ser legado, doado, ou cedido; b) não é suscetível de penhora em execução; c) não entra na falência, nem a massa creditória dele dispõe; d) não pode constituir quota social; e) não é desapropriável. Ainda mais o nome é imprescritível ${ }^{185}$.

Conclui sua tese afirmando que: "pelo fato de ser firma comercial exclusiva de quem a inscreveu no registro não se conclui constituir objeto de propriedade, seria apenas um monopólio de direito privado, consistente no direito de impedir o uso por terceiro de nome idêntico ou similar. O exclusivismo é instituído em benefício do comércio para evitar fraudes e, portanto, no interêsse público. É a concorrência desleal que se procura combater" ${ }^{186}$.

Para FRÓES, "muito embora o nome comercial tenha um valor econômico inegável, a ponto de considerarem alguns tratadistas que integra o fundo de comércio, não nos parece que possa ser concebido como direito de propriedade, porque lhe falta um dos requisitos essenciais para tal, que é o da disponibilidade. De fato, o nome comercial, no sistema do direito brasileiro, é incessível ou intransferível, o que demonstra não ser objeto de um direito real, mas, sim, de um direito pessoal. O mesmo não ocorre com o elemento de fantasia constante da denominação, que, em geral, é marca de indústria e comércio ou marca de serviço" ${ }^{187-188}$.

\footnotetext{
181 in Tratado da Propriedade Industrial, cit., vol. 1, p. 486

${ }^{182}$ Ressalte-se usamos a expressão direito pessoal como sendo aquele de caráter obrigacional, ou seja, direito pessoal em relação a terceiros, não se confundindo com o direito personalíssimo (direito pessoal relativo ao próprio sujeito) V. PICARD, Edmond. O direito puro, 2a ed., Salvador : Progresso, 1954

183 MendOnÇA, José Xavier Carvalho de. Op. cit., p. 154 e ss.

184 Clóvis BEVILÁQUA tem a mesma opinião de que o direito de quem inscreveu a firma é direito pessoal absoluto, in Teoria Geral do Direito Civil, n. 56

${ }^{185}$ MendOnÇA, José Xavier Carvalho de. Op. cit., p. 154/155

${ }^{186}$ Idem, Ibidem.

${ }^{187}$ FróES, Carlos Henrique de Carvalho. Nome comercial III. Enciclopédia Saraiva de Direito, São Paulo: Saraiva, 1977, p. 316
} 
Na mesma linha do caráter obrigacional defendido por CARVALHO DE MENDONÇA, mais recentemente, manifestou-se GABRIEL FRANCISCO LEONARDOS, para o qual o direito ao nome comercial seria um direito pessoal, derivado da repressão à concorrência desleal. Para o autor, "[n]ão se trata de direito de propriedade porque lhe faltam diversos elementos e atributos da propriedade. Tampouco se trata de uma projeção da personalidade do comerciante sobre seus negócios, tendo em vista que a proteção ao nome comercial tem fundamento exclusivamente utilitário, que objetiva proteger os investimentos feitos para se formar a reputação de um nome, a par de proteger os consumidores que se habituaram a associar uma determinada qualidade a um dado nome" ${ }^{\text {189 }}$.

Vale menção, ainda, a uma quarta teoria que trata de maneira diferenciada o direito ao nome empresarial, conforme se trate de firma ou denominação. Para JUSTINO VASCONCELLOS, "a essência da firma é o nome personativo, a da denominação o objeto da emprêsa; a primeira se vincula ao comerciante, e a segunda ao comércio; a firma é pessoal, a denominação é real” ${ }^{190}$. Nesse sentido, também, RUBENS REQUIÃo, que identifica a firma individual com o nome do empresário, e como tal, um atributo da personalidade; e o mesmo ocorre com as firmas ou razões sociais; as denominações, no entanto, constituiriam um bem imaterial ${ }^{191}$.

Embora a questão da fixação da natureza do nome empresarial aparente, em um primeiro momento, ter conotação apenas acadêmica, é, na verdade, de descomunal relevância para delinear a extensão e o âmbito de proteção do nome empresarial. Isso porque, se considerarmos o nome empresarial como direito personalíssimo do empresário, sua proteção será absoluta, independentemente de relação de concorrência, a qual somente atuará como fator agravante ${ }^{192}$. Se entendermos tratar-se de direito pessoal (ou obrigacional), a relação de concorrência é inerente para que se apliquem as normas de violação de nome empresarial, previstas na LPI, fulcradas na repressão à concorrência

\footnotetext{
${ }^{188}$ GRAU-KUNTZ concorda com FRÓES, exceto no tocante às denominações, pois, segundo a autora, "[n]o sistema do direito brasileiro, que concede personalidade a todas as pessoas jurídicas, e que vê na adoção do nome inclusive uma das condições para a concessão daquela, o nome comercial, tanto em seu elemento firma como denominação, não poderá ser objeto de cessão ou transferência, o que faz dele objeto de um direito pessoal" (op. cit., p. 63)

${ }^{189}$ LEONARDOS, Gabriel Francisco. A proteção jurídica ao nome comercial, ao título de estaebelecimento e a insígnia no Brasil, Revista da ABPI nº 13, nov./dez., de 1994, p. 20 e ss.

${ }^{190}$ VASCONCELOS, Justino. Das firmas e denominações comerciais, cit., p. 31

${ }^{191}$ REQUĩ̃o, Rubens. Curso de Direito Comercial, cit., p.163.

${ }^{192}$ No dizer de GAMA CERQUEIRA: "[n]ão importa que diversifique o gênero de comércio ou indústria explorado, porque a proteção do nome comercial não pressupõe necessariamente o elemento concorrência, circustância que, entretanto, influi para agravar a possibilidade de confusão e as suas consequências" (in Tratado da Propriedade Industrial, cit., vol. II, t. II, p. 321).
} 
desleal. Diferente também será o tratamento se o considerarmos propriedade do empresário, exercida sobre uma coisa incorpórea, com eficácia erga omnes.

"Consideramos", dizia GAMA CERQUEIRA, "o nome comercial objeto da propriedade industrial, exclusivamente em sua função objetiva, não podemos acompanhar a doutrina do direito pessoal, que assenta, de modo essencial, na função subjetiva do nome comercial, como simples designação da pessoa do comerciante, sujeito de direitos" 193. Procurou, assim, tratar de forma diferenciada cada uma das funções desempenhadas pelo nome empresarial, em uma tentativa de definir sua natureza.

A despeito de a jurisprudência, atualmente, considerar o nome empresarial como uma propriedade ${ }^{194}$, a nosso ver, não há como negar que o direito ao nome empresarial decorre da personalidade jurídica do empresário ou da sociedade empresária, máxime pela função identificadora (subjetiva) que exerce o nome empresarial, a qual é, inclusive, anterior à função objetiva (o que explicitaremos mais adiante), do uso do nome no exercício da atividade econômica.

Este entendimento é, agora, corroborado pelo $\mathrm{CC}$, uma vez que: a) assegura às pessoas jurídicas, no que couber, proteção aos direitos de personalidade e, conseqüentemente, ao nome (art. 52 c.c. 16); b) traz norma vedando a alienação do nome empresarial (art. 1.164), sendo certo que o direito de dispor da coisa é uma das características essenciais do direito de propriedade ${ }^{195}$; e c) estabelece a imprescritibilidade da ação de anulação de ação para anular a inscrição do nome empresarial feita com violação da lei ou do contrato (art 1.167).

Outrossim, podemos dizer que a função subjetiva é inerente e indissociável ao nome empresarial, haja vista também o interesse público envolvido, ao passo que a função objetiva é acessória e facultativa, surgindo apenas quando o nome empresarial (ou melhor,

\footnotetext{
${ }^{193}$ Op. cit., p. 1.168

${ }^{194}$ V. NOME COMERCIAL. AÇÃO DE PRECEITO COMINATORIO, CUMULADA COM PEDIDO DE

PERDAS E DANOS. O direito sobre o nome comercial, segundo entendimento hoje prevalecente na doutrina e na jurisprudência, constitui uma propriedade, a semelhança do que ocorre com as marcas de fabrica e de comercio, motivo pelo qual, em ações por violação de seu uso exclusivo, se aplica o lapso prescricional previsto no art. 178, par-10., inciso IX, do Código Civil. Recurso especial não conhecido. (STJ, $4^{\text {a }}$ T., REsp 4.055/PR, Rel. Min. Barros Monteiro, , j. em 19.03.1991, DJ 20.05.1991 p. 6532);

PROPRIEDADE INDUSTRIAL. MARCA. NOME COMERCIAL. A precedência do registro de marca no INPI, e do nome na Junta Comercial, além da notoriedade, garantem a proprietária contra o uso de nome e marca cuja semelhança possa induzir em erro o consumidor. Recurso não conhecido. (STJ, $4^{\mathrm{a}} \mathrm{T}_{\text {., }}$ REsp 30.751/SP, Rel. Min. Ruy Rosado de Aguiar, j. em 07.06.1994, DJ 01.08.1994, p. 18.653)

${ }^{195}$ Este também é o entendimento de GABRIEL F. LEONARDOS: “[o] novo Código Civil, por seu turno, em seu art. 1.164, veda a alienação do nome empresarial, o que igualmente indica que o direito sobre o mesmo não é de propriedade, pois esta tem como um de seus atributos, como sabemos, o direito de disposição da coisa (cf. art. 1.228 do novo CC)", concluindo tratar-se de direito pessoal de seu titular (in A proteção ao nome empresarial, cit., p. 144).
} 
nome comercial) é efetivamente usado pelo empresário no campo concorrencial. E nesse sentido, vale dizer, que por demais das vezes acaba em segundo plano, pois se transforma usualmente em marca e/ou título de estabelecimento, máxime pelo número cada vez menor de firmas, haja vista a cultura empresarial brasileira que preconiza a constituição de sociedades limitadas e anônimas, identificadas por denominações, nestas de caráter obrigatório e naquelas facultativo.

\section{A adoção do patronímico como nome comercial}

No primeiro capítulo, verificamos que a toda pessoa é assegurado o direito ao nome, nele contidos o prenome e o patronímico (nome de família). Tutela-se, outrossim, o pseudônimo adotado pela pessoa, já que passa a exercer função similar ao nome, identificando o indivíduo perante a coletividade. Trata-se de direito personalíssimo de seu titular, sendo o nome do indivíduo o símbolo da sua personalidade, o sinal que o particulariza, caracteriza e distingue na vida social. Em sendo o nome o sinal identificador da pessoa perante a sociedade, era natural que a pessoa ao iniciar uma atividade empresarial adotasse seu próprio nome em seu exercício.

Desta forma, no início do tráfico mercantil, os comerciantes usualmente adotavam seu próprio nome civil no exercício de sua atividade e, assim, com ele identificavam seus produtos e o próprio estabelecimento comercial. Daí o surgimento primeiro das firmas e razões sociais e, apenas em um segundo momento, das denominações, inicialmente ligadas exclusivamente às sociedades anônimas.

A firma, relembrando, é o nome utilizado pelo empresário, pela sociedade em que houver sócio de responsabilidade ilimitada e, de forma facultativa, pela sociedade limitada, sendo constituída pelo nome, completo ou abreviado, do empresário ou, no caso de sociedades, de uma ou mais sócios.

"Com a incorporação do nome patronímico (civil), ou de parte dele, ao nome comercial ou à denominação da sociedade anônima", lecionou DUVAL, "o nome destaca-se da pessoa física de seu titular para constituir elemento valioso do patrimônio da pessoa jurídica incorporadora dele" (...) “Talvez até com mais força atrativa do que uma denominação de fantasia, pois a reputação da empresa estaria, afinal, identificada pela de 
seu próprio titular, tornando-se assim mais vulnerável à agressão da $\mathrm{CD}$ (concorrência desleal)" 196.

A adoção da firma, como já visto, acarreta a responsabilidade ilimitada do empresário ou dos sócios da sociedade quanto às dívidas da sociedade ${ }^{197}$. Ademais, ao optar por adotar a firma, o empresário ou sócios devem ter em consideração as eventuais conseqüências que o uso da firma poderá gerar, especialmente considerando que, atualmente, o nome de sócio que vier a falecer, for excluído ou se retirar, não pode ser conservado na firma social ${ }^{198}$.

No dizer de GHIRON: “[i]l proprietário dell'azienda ha dunque la facoltà esclusiva di adottare la sua ditta como segno distintivo in tutte le manifestazioni della sua azienda" ${ }^{\prime 199}$. Assim, pode o empresário usar sua firma na fachada do estabelecimento, nos papéis, nas etiquetas e rótulos, nas faturas e notas fiscais, na sua marca, ou seja, das mais diversas formas para atrair a clientela.

Nesse sentido, é ainda hoje aplicável o alerta de Hermano Duval: "[a]s conseqüências da inábil associação do nome patronímico ao nome comercial não são imediatas: projetam-se no tempo, principalmente no futuro, quando o sócio, que deu seu nome à sociedade, dela retira-se para fundar outra ou falece, continuando o nome com os sobreviventes. Surgem, então, as demandas de abstenção ou reivindicação, em que o preço da vaidade inicial pode conduzir a um desfecho imprevisto" 200.

Podemos, então, afirmar que a toda pessoa é assegurado o direito de adotar seu nome civil no exercício de sua atividade empresarial. Porém, esta regra comporta certo temperamento ${ }^{201}$. Conquanto o nome comercial deva ser distintivo, é evidentemente impossível que vários empresários adotem o mesmo nome comercial, ainda que tenham o mesmo nome civil, pois, este caso, o nome comercial não poderia cumprir sua função identificadora ${ }^{202-203}$.

\footnotetext{
${ }^{196}$ DuVAL, Hermano. Concorrência desleal. São Paulo: Saraiva, 1976, p. 162

${ }^{197}$ Cf. parágrafo único do art. 1.157 , do $\mathrm{CC}$

${ }^{198}$ Cf. art. 1.165, do CC

${ }^{199}$ GHIRON, Mario. Corso de Diritto Industriale, cit., p. 229

${ }^{200}$ Duval, Hermano. Concorrência desleal. São Paulo: Saraiva, 1976, p. 162

${ }^{201}$ Ensinam LANGE, David, LAFRANCE, Mary e MYERS, Gary que: “[t]he so-called 'sacred right' theory that every man may employ his own name in his business is not unlimited" (in Intellectual Property: cases and materials. St.Paul, Minn.: West Group, 1998

${ }^{202}$ Cf. AsCARELl, Tullio. Teoría de la concurrencia, cit., p. 365

${ }^{203}$ Nesse sentido "[t]he defendant has the right to use his name. The plaintiff has the right to have the defendant use it in such a way as will not injure his business or mislead the public. Where there is such conflict of rights, it is the duty of the court so to regulate the use of his name by the defendant that, due protection to the plaintiff being afforded, there will be as little injury to him as possible" (World's Dispensary Medical Ass'n v. Pierce, 203 N.Y. p. 425, 96 N.E. p. 740)
} 


\subsection{A questão dos homônimos}

O nome civil corresponde necessariamente a toda pessoa física, de tal modo que se relaciona com a existência e, assim, pode ser idêntica para sujeitos distintos. Em outras palavras, em se tratando de nome civil é permitida a homonímia.

O mesmo, contudo, não ocorre com os nomes empresariais, os quais devem ser obrigatoriamente distintos. Como ensinou ASCARELLI, "[p]ara que el bien inmaterialnombre comercial exista es, pues, necesaria su creación por parte del empresario: necesaria, por tanto, una creación (intelectual, aunque modestísima) caracterizada, precisamente, por su función distintiva con respecto al empresario como persona que ejercita una empresa" 204.

No mesmo sentido a lição de DI FRANCO: “[p]erchè dunque assuma capacita distintiva, occorre che il proprio nome si differenzi da quello di chi si è precedentemente stabilito, in modo da assumere a sua volta, con tali differenziazioni, virtù identificatrice e distintiva originaria ed originale ${ }^{205}$.

O Decreto 916/1890 previa que a proibição de se inscrever firma homônima ou similar era limitada à circunscrição territorial do registro, à respectiva comarca. Criticava tal limitação CARVALHO DE MENDONÇA, asseverando que “[a] firma não devia ser local, mas gozar de tutela jurídica, não diremos em todo o território da República, porém, no território dos Estados, em cada um dos quais existe a Junta comercial, a cujo cargo está o registro do comércio, sem prejuízo das inscrições provisórias nas comarcas, distantes da capital, sede dessas repartições. Firmas iguais ou semelhantes dentro do mesmo Estado e sòmente diferentes no lugar de registro, trazem confusão fora do Estado, onde se não conhecem as comarcas" 206.

Atualmente, o CC dispõe que o nome de empresário deve distinguir-se de qualquer outro já inscrito no mesmo registro. Se o empresário tiver nome idêntico ao de outros já inscritos, deverá acrescentar designação que o distinga ${ }^{207}$.

Logo, todo empresário tem o direito irrestrito de usar sua própria firma ou emprestar seu patronímico à sociedade, mas, em havendo homonímia, deverá agregar designação que a distinga. É dizer que seu patronímico só poderá compor o nome de

\footnotetext{
${ }^{204}$ ASCARELLI, Tullio. Op., cit., p. 363

${ }^{205}$ Di FranCO, Luigi. Trattato della Proprietà Industriale, cit., p. 364

${ }^{206}$ MendonçA, José Xavier Carvalho de. Tratado de Direito Comercial Brasileiro, cit., p. 174
} 
empresa se forem respeitados os direitos de terceiros oriundos de firmas previamente constituídas.

No magistério de DI FRANCO: "[l] a necessità di eliminare anche nella formazione della ragione sociale ogni possibilità di confusione con l'omonimo precedentemente stabilitosi non può condurre al divieto assoluto dell'uso del próprio nome, anche quando eventualmente nella società 'lomonimo sia richiesto od accolto appunto in considerazione dell'omonimia con altro industriale o commerciante, la cui reputazione e credito si siano già affermati” ${ }^{208}$.

Este entendimento é, há muito, assente, tanto na doutrina quanto na jurisprudência ${ }^{209}$. VIVANTE, no início do século XX, já dizia que "[t]odo o commerciante, nacional ou estrangeiro, tem o direito exclusivo de usar a propria firma, independentemente de qualquer deposito ou de qualquer publicidade (...) Se dois commerciantes teem o mesmo nome e cognome, e d'esta uniformidade podem soffrer damno, aquelle que provar o uso precedente e legitimo da firma commum poderá obrigar o outro a fazer na sua as modificações necessarias para impedir a confusão, porquanto a prioridade da posse constitue o titulo de preferência n'esta materia" ${ }^{210}$.

Em França, esclarecia RoUBIER, para exercer o comércio era necessário enunciar a firma ao magistrado (já que o registro era realizado no Tribunal do Comércio), indicando o nome patronímico e prenome que desejasse inscrever no registro do comércio, e ainda declarar que sua firma era claramente distinta das firmas já existentes ${ }^{211-212}$.

Em se tratando de firma, a regra geral, repise-se, é de que o empresário tem o direito de usar seu nome civil como firma, devendo, em caso de homonímia, acrescer designação que o distinga. Todavia, o mesmo não ocorre em se tratando de denominações. Como bem acentuou GHIRON: "[i]l pericolo di confusione tra i nomi può sorgere per via motivi: per somiglianaza fonética, per identità casuale o dovuto a ragioni di parentela,

\footnotetext{
${ }^{207}$ Cf. art. 1.163 , do CC

${ }^{208}$ Di FRANCO, Luigi. Op. cit., p. 365

${ }^{209}$ Em recente acórdão, sobre o uso do patronímico Koch, o STJ reafirmou tal entendimento, valendo citar o seguinte excerto: "[s]opesando-se, assim, o direito de marca com o direito de livre e responsável exercício da profissão de advogado, a solução razoável exige que, mesmo sem deixar de utilizar o patronímico de seus sócios, a sociedade requerida venha a fazer incluir em sua razão social outros elementos distintivos que

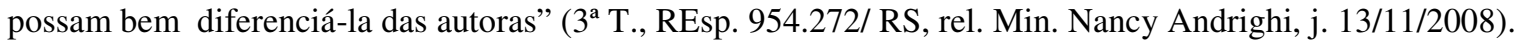
Vide também: $3^{a}$ T., REsp 406.763/SP, Rel. Min. Menezes Direito, DJ 11/11/2002 e 4ª T., AgRg no REsp 653.609, Rel. Jorge Scartezzini, DJ 06/12/2004.

${ }^{210}$ VivanTE, Cesare. Instituições de Direito Commercial, traducção de J. Alves de Sá, cit., p. 42/43

${ }^{211}$ Cf. RoubIER, Paul. Op. cit., p. 670

${ }^{212}$ Quanto ao problema da homonimia, dizia ROUBIER: “C'est un moyen très radical de résoudre le problème délicat de l'homonymie, et le juge a le pouvoir disciplinaire qui lui permet d'obtenir que la loi soit obéie ; il
} 
ecc” 213 . Assim, a denominação adotada posteriormente deve ser necessariamente distinta daquela preexistente, pois desprovida de elemento diferenciador e, desta forma, suscetível de causar confusão.

\section{A inalienabilidade do nome empresarial}

O nome empresarial não pode ser objeto de alienação, preceitua o art. 1.164, do CC. O fundamento de tal proibição é o fato de que certas denominações, ao mesmo tempo, identificam o empresário ${ }^{214}$, como sujeito de direito e obrigações dentro da generalidade dos atos inerentes à sua atividade (função subjetiva ou identificadora), e distinguem seu titular de seus concorrentes no âmbito das atividades econômicas, ou seja, no campo da concorrência (função objetiva ou econômico-concorrrencial). A inalienabilidade do nome empresarial reforça o entendimento de que o nome empresarial constitui direito de personalidade de seu titular.

Todavia, é importante esclarecer que, enquanto o nome empresarial não pode ser cedido, a pessoa jurídica que identifica pode ser alienada, através da negociação da totalidade de suas quotas ou ações. Não se trata de alienação do próprio nome empresarial, que remanesce o mesmo, mas do sujeito por ele identificado. Neste caso não há propriamente a cessão do nome empresarial, mas sim do aviamento como um todo, de modo que a proibição acaba apenas por exigir que não seja fixado no contrato de trespasse o valor individualizado do nome empresarial, mas este certamente fará parte do preço global do negócio.

Como bem observou VerçosA, "ao proibir que o nome empresarial possa ser objeto de alienação, o NCC, no seu art. 1.164, estaria fazendo referência tão-somente ao seu aspecto subjetivo, uma vez que, interpretado o dispositivo em sentido mais amplo, estaria havendo uma proibição inconstitucional do direito de propriedade que o titular do estabelecimento tem em relação aos aspectos objetivos no nome empresarial, conceituados como bens, de acordo com a melhor doutrina" ${ }^{215}$. Isso porque o nome comercial está compreendido no conjunto de bens incorpóreos que, somados aos bens corpóreos, compõem o estabelecimento.

peut refuser l'inscription de la firme, en pareil cas. Ce pouvoir n'a d'ailleurs aucun caractère arbitraire, car il existe un recours à une juridiction supérieure contre le refus d'inscription" (op. cit., p. 670)

${ }^{213}$ GHIRON, Mario. Corso di Diritto Industriale, cit., p. 230

214 Aqui entendido em seu sentido amplo, abarcando o empresário individual e as sociedades.

${ }^{215}$ VerçosA, Haroldo Malheiros Duclerc. Curso de Direito Comercial, cit., p. 260/261 
Assim, por estar relacionado à pessoa do empresário, o nome empresarial, a rigor, não pode ser alienado. Contudo, alguns autores, como GHIRON ${ }^{216}$ e RoUBIER, tinham como possível a alienação as firmas. Dizia RoUBIER, "o nome comercial pode ser cedido: na verdade, não pode ser cedido separadamente, porque as cessões deste tipo induziriam terceiros em erro, mas pode ser cedido - e normalmente é cedido - com o fundo que designa. Esta cessão geralmente é realizada a título oneroso, e constitui freqüentemente o elemento mais importante do fundo transmitido" ${ }^{217}$.

\subsection{Nome empresarial derivado}

Todavia, ressalte-se que há uma exceção à regra da inalienabilidade do nome empresarial: o nome empresarial derivado, previsto no parágrafo único, do art. 1.164, do CC. Assim, o adquirente de um estabelecimento, por ato entre vivos, pode, se o contrato o permitir, usar o nome do alienante, precedido do seu próprio, com a qualificação de sucessor.

Nesse caso, observou VERÇOSA, estar-se-ia "abrindo uma exceção expressa para a utilização do aspecto subjetivo do nome do empresário alienante" ${ }^{218}$. Ora, o que é isso se não uma forma de alienação da firma? O adquirente, com a ressalva que a lei faz, continuará usando a firma do antecessor e, assim, beneficiando-se de seu poder atrativo. Por estas razões, GHIRON entendia plenamente possível a cessão das firmas ${ }^{219}$.

Não concordamos, portanto, com PONTES DE MiRANDA, o qual entende que não se trata de cessão, mas apenas outorga, ao sucessor, do direito à alusão pública ao fato da sucessão $^{220}$.

\section{A alteração do nome empresarial}

É importante destacar, ademais, que o nome empresarial não é imutável, seja em relação às firmas, seja no tocante às denominações. Evidentemente, há maior rigidez

\footnotetext{
${ }^{216}$ GHIRON, Mario. Corso di Diritto Industriale, cit, p. 228.

${ }^{217}$ Cf. RoubIER, Paul. Le Droit de la Propriété Industrielle, cit., p. 667

${ }^{218}$ VerÇOSA, Haroldo Malheiros Duclerc. Curso de Direito Comercial, cit., p. 261

219 "Poichè, come si è accennato, la ditta, secondo noi, è cedibile, anzi dev'essere ceduta se si vuole che l'azienda passi integra al sucessore, cosi noi riteniamo che chi riceve l'azienda nel si complesso, riceve implicitamente senz'altro il suo elemento essenziale che è la ditta, onde l'acquirente dell'azienda a causa di morte o per atto fra vivi, può adoperare como strumento di richiamo la ditta che già adoperava il dante causa" (GhIRon, Mario. Corso di Diritto Industriale, cit, p. 228).

${ }^{220}$ Op. cit., p. $227 / 228$
} 
quanto às firmas, haja vista o dever de veracidade. Porém, este mesmo dever de veracidade impõe a alteração da firma quando o nome civil do empresário tenha sido alterado, o que pode ocorrer em razão de casamento, divórcio, decisão judicial ${ }^{221}$, enfim em todos os casos que a lei autorize.

A firma, como vimos, pode conter, se o empresário quiser ou para diferenciar-se obrigatoriamente de outra preexistente, designação mais precisa da sua pessoa ou do gênero de atividade. Desta maneira, se houver alteração quanto à qualidade da pessoa do empresário ou do gênero de atividade que constem na firma, esta igualmente deverá ser modificada.

Nesse sentido, a IN n ${ }^{\circ} 104$, do DNRC, dispõe que empresário poderá modificar a sua firma. Em havendo modificação do nome civil de empresário, averbada no competente Registro Civil das Pessoas Naturais, deverá ser arquivada alteração com a nova qualificação do empresário, devendo ser, também, modificado o nome empresarial. Se a designação diferenciadora se referir à atividade, havendo mudança, deverá ser registrada a alteração da firma (art. 12).

No que concerne às denominações, tendo em vista a liberdade que têm os sócios para compô-las, observadas as regras de formação, também há possibilidade de modificação. Logo, a denominação pode ser alterada, desde que observadas às regras de formação relativas ao tipo societário, assim como o dever de novidade.

Caso a denominação contenha expressão designativa do objeto social, como atualmente exigido para as sociedades anônimas e limitadas, em sendo alterado o objeto social deverá ser, por conseguinte, modificado o nome empresarial, fazendo constar na denominação expressão designativa do novo gênero, sob pena de vulneração do dever de veracidade. Ademais, caso seja alterado o tipo societário, por exemplo, alteração de sociedade limitada para anônima, o nome empresarial deverá ser alterado, de acordo com as regras do novo tipo societário.

\section{A extinção do nome empresarial}

O direito ao nome comercial exaure-se com a extinção da atividade empresarial ${ }^{222}$. Consoante reza o art. 1.168, do CC, a inscrição ${ }^{223}$ do nome empresarial será cancelada, a

\footnotetext{
${ }^{221}$ Cf. vimos no número 5, do Cap. I, supra.

${ }^{222}$ A extinção da empresa pode dar-se por causas naturais (morte do empresário ou totalidade dos sócios; ou incapacidade superveniente do empresário individual), voluntárias (cessação voluntária da atividade pelo
} 
requerimento de qualquer interessado, quando cessar o exercício da atividade para a qual foi adotado ${ }^{224}$, ou quando se ultimar a liquidação da sociedade que o inscreveu ${ }^{225-226}$.

Mais especificamente em relação à firma ou razão social extingue-se com a cessação do exercício da atividade ${ }^{227}$, o que acontece quando o empresário morre ${ }^{228}$ ou abandona voluntariamente a profissão; liquidação da sociedade empresária; transformação da sociedade ilimitada em sociedade com responsabilidade limitada, como, v.g., as sociedades anônimas e limitada ${ }^{229}$.

Vale dizer, ainda, que a empresa mercantil que não proceder a qualquer arquivamento no período de dez anos, contados da data do último arquivamento, deverá comunicar à Junta Comercial que deseja manter-se em funcionamento, sob pena de ser considerada inativa, ter seu registro cancelado e perder, automaticamente, a proteção de seu nome empresarial ${ }^{230}$.

empresário individual ou consenso entre os sócios), fáticas (são diversas: caso fortuito, falta de algum dos fatores de produção etc.) ou legais (falência, liquidação extrajudicial e cassação de autorização pelo Poder Público para o funcionamento).

${ }^{223}$ Como vimos, não há, nem deve haver, um registro específico para os nomes comerciais, de modo que se evidencia a impropriedade da redação do artigo, ao referir-se à inscrição do nome, já que existe apenas o arquivamento dos atos constitutivos da sociedade.

${ }^{224}$ Expirado o prazo da sociedade celebrada por tempo determinado, esta perderá a proteção do seu nome empresarial, cf. art. 59, da Lei 8.934/94

${ }_{225}$ As sociedades dissolvem-se pelo vencimento do prazo de duração, salvo se, vencido este e sem oposição de sócio, não entrar a sociedade em liquidação, caso em que se prorrogará por tempo indeterminado; consenso unânime dos sócios; deliberação dos sócios, por maioria absoluta, na sociedade de prazo indeterminado; falta de pluralidade de sócios, não reconstituída no prazo de cento e oitenta dias; extinção, na forma da lei, de autorização para funcionar. As sociedades empresárias, se dissolvem, ainda, pela declaração da falência (cf. arts. 1033 e 1044, do CC, e art. 206 e ss. da Lei das Sociedades Anônimas).

${ }^{226}$ Vale dizer que ao final dos nomes dos empresários e das sociedades empresárias que estiverem em processo de liquidação, após a anotação no Registro de Empresas, deverá ser aditado o termo "em liquidação" (cf. art. 16, da IN 104/2007, do DNRC).

${ }^{227}$ Observe-se que a interrupção momentânea da atividade não é causa de extinção do direito ao nome empresarial

${ }^{228}$ Cf. art. 1.165, do CC.

${ }^{229}$ Cf. MendonçA, José Xavier Carvalho de. Tratado de Direito Comercial Brasileiro, cit., p. 181/182

${ }^{230}$ Cf. art. 48 , caput, do Decreto ${ }^{\circ} 1.800 / 1996$ 


\section{Capítulo III}

\section{O NOME DO EMPRESÁRIO E DAS SOCIEDADES EM ESPÉCIE}

\section{O nome do empresário}

O Código Civil define empresário como quem exerce profissionalmente atividade econômica organizada para a produção ou a circulação de bens ou de serviços. Considerase empresário, também, quem exerce profissão intelectual, de natureza científica, literária ou artística, ainda com o concurso de auxiliares ou colaboradores, cujo exercício da profissão constituir elemento de empresa ${ }^{231}$.

Logo, excluem-se do conceito de empresário (“empresário comercial ou mercantil”) (a) a atividade de natureza eminentemente intelectual e (b) a atividade rural ("empresário rural" ${ }^{232}$ ).

Existem duas espécies de empresários: o empresário individual e a sociedade empresária. O empresário individual é a pessoa física que responde pessoalmente com seus bens pelas obrigações contraídas, seja de natureza civil seja comercial.

O empresário deve obrigatoriamente inscrever-se no Registro Público de Empresas Mercantis da respectiva sede, antes do início de sua atividade, e, no ato da inscrição, declarar a firma adotada ${ }^{233}$.

Observe-se que há referência expressa à firma adotada, já que, como visto, é vedado ao empresário individual o uso de denominação social. Nesse sentido, reza o art. 1.156, do CC que o empresário opera sob firma constituída por seu nome, completo ou abreviado, aditando-lhe, se quiser - ou quando já existir nome idêntico - designação mais precisa da sua pessoa ou do gênero de atividade.

Em outras palavras, o empresário só poderá adotar como firma o seu próprio nome, aditando, se quiser ou quando já existir nome empresarial idêntico, designação mais precisa de sua pessoa ou de sua atividade ${ }^{234}$.

\footnotetext{
${ }^{231}$ Cf. art. 966, § único, do CC.

${ }^{232}$ O CC prevê a possibilidade de o empresário rural, cuja atividade rural constitua sua principal profissão, requerer sua inscrição no Registro Público de Empresas Mercantis, equiparando-se ao empresário mercantil (cf. art. 971)

${ }^{233}$ Cf. arts. 967 e 968 , inc. II, do CC.

${ }^{234}$ Cf. art. $5^{\circ}$, inc. I, da IN n ${ }^{\circ} 104 / 2007$, do DNRC
} 


\section{Sociedades não personificadas}

\subsection{Sociedade em comum}

Celebram contrato de sociedade as pessoas que reciprocamente se obrigam a contribuir, com bens ou serviços, para o exercício de atividade econômica e a partilha, entre si, dos resultados, diz o art. 981, do CC. Assim, a pluralidade de sócios é pressuposto de existência de toda sociedade, com a ressalva da sociedade subsidiária integral ${ }^{235}$ e das sociedades unipessoais temporárias ${ }^{236}$.

Assim, são consideradas sociedades em comum (ou sociedades de fato) aquelas que possuam dois ou mais sócios com interesse comum em exercer empresa e partilhar os resultados, mas cujos atos constitutivos ainda não foram arquivados no respectivo registro (art. 986, do CC). A sociedade é, portanto, irregular ${ }^{237}$, por não possuir contrato social ou por não ter arquivado seus atos constitutivos no registro respectivo, antes do início de sua atividade $^{238}$. Nas sociedades em comum, os sócios respondem solidária e ilimitadamente pelas obrigações sociais (art. 990, do CC).

Como estudaremos no próximo capítulo, a proteção ao nome empresarial no Brasil surge com a inscrição dos atos constitutivos no respectivo registro. Ora, por não haver registro dos atos constitutivos e, assim, não haver sociedade regular dotada de personalidade jurídica, não há proteção ao nome empresarial das sociedades em comum, ainda que exista contrato escrito que declare a firma ou denominação.

\subsection{Sociedade em conta de participação}

Por seu turno, a sociedade em conta de participação não pode ter firma ou denominação ${ }^{239}$, justamente por não possuir personalidade jurídica ${ }^{240}$, sendo que as atividades são desenvolvidas sob o nome civil do sócio ostensivo.

\footnotetext{
${ }^{235}$ Cf. art. 251, da Lei das Sociedades Anônimas

${ }^{236}$ Cf. art. 206, inc. I, “d”, da Lei das Sociedades Anônimas e art. 1.033, inc. IV, do CC

${ }^{237}$ Alguns doutrinadores, como Waldermar FERREIRA, subdividem-nas em sociedades irregulares e sociedades de fato. Aquelas possuiriam contrato social escrito, mas não arquivado e estas, por seu turno, sequer possuiriam contrato escrito. Em ambos os casos, a falta de registro implica na submissão da sociedade às regras das sociedades em comum (Cf. Tratado de Direito Comercial, cit.).

${ }^{238}$ O art. 967, do CC, traz a obrigatoriedade de inscrição do empresário no Registro Público de Empresas Mercantis da respectiva sede, antes do início de sua atividade.

${ }^{239}$ Cf. art. 1.162, do CC. O Decreto 916/1890 já continha disposição similar, notadamente seu art. $3^{\circ}, \S 4^{\circ}$ que rezava que "a sociedade em conta de participação não poderá ter firma que indicie existência de sociedade".
} 


\section{Sociedades personificadas}

\subsection{Sociedades simples}

São consideradas sociedades simples aquelas que não têm por objeto o exercício de atividade própria de empresário sujeito a registro (art. 967) ${ }^{241}$, ou seja, embora tenham por objeto o exercício de atividade econômica organizada de produção ou circulação de bens ou serviços, realizam operações econômicas de natureza não empresarial ${ }^{242}$. $\mathrm{O}$ modo como exploram seu objeto social é que as diferenciam das sociedades empresárias.

Assim, não se vinculam ao Registro Público de Empresas Mercantis, bem como não se submetem às normas relativas ao empresário.

As sociedades simples podem adotar qualquer forma de sociedade empresária, ou seja: sociedade em nome coletivo, sociedade em comandita simples e sociedade limitada. É evidente que não poderão constituir-se em forma de sociedade por ações, a qual é sempre empresária (art. 982, § único, do CC).

Nos termos do art. 997, inc. II, do CC, os atos constitutivos da sociedade simples deverão ser arquivados, no Registro Civil das Pessoas Jurídicas, indicando a denominação adotada. Contudo, poderíamos até mesmo considerar a utilização de firma social pela sociedade simples, haja vista a liberdade que têm os sócios de estipular se respondem ou não, subsidiariamente, pelas obrigações sociais. Logo, se a responsabilidade pelas obrigações sociais pode ser limitada ou ilimitada, pode a sociedade simples, a rigor, adotar firma ou denominação social conforme o tipo societário adotado.

\subsection{Sociedade em nome coletivo}

Como vimos, nas sociedades em que os sócios respondem solidária $e$ ilimitadamente pelas obrigações contraídas, deve ser adotada firma. É o que ocorre com as sociedades em nome coletivo, que devem ter necessariamente firma social ${ }^{243}$.

\footnotetext{
${ }^{240}$ O art. 993, do CC dispõe, inclusive, que mesmo levando-se a registro o contrato social, não lhe é conferida personalidade jurídica. Trata-se de sociedade oculta, chamada na doutrina alemã de stille Gesselschaft, existente, portanto, somente entre os sócios.

${ }^{241}$ Cf. art. 982 , do CC

${ }^{242}$ Cf. art. 966 c.c. art. 981 , do CC.

${ }^{243}$ Cf. art. 1.041 , do CC.
} 
A firma da sociedade em nome coletivo, se não individualizar todos os sócios, deverá conter o nome de pelo menos um deles, acrescido do aditivo "e companhia", por extenso ou abreviado.

\subsection{Sociedade em comandita simples}

Também, haja vista a responsabilidade solidária e ilimitada de algum dos sócios, a sociedade em comandita simples deverá adotar firma social, contendo conter o nome de pelo menos um dos sócios comanditados, com o aditivo "e companhia", por extenso ou abreviado.

Ainda, não pode o comanditário ter o nome na firma social, sob pena de ficar sujeito às responsabilidades de sócio comanditado (art. 1.047, do CC).

\subsection{Sociedade limitada}

As regras reguladoras do nome empresarial das sociedades limitadas encontram-se previstas no CC, o qual revogou tacitamente o Decreto $\mathrm{n}^{\mathbf{0}} 3.708 / 1919$, que inseriu as sociedades por quotas de responsabilidade limitada em nosso ordenamento jurídico ${ }^{244}$.

As sociedades limitadas podem adotar firma ou denominação, integradas pela palavra final "limitada" ou a sua abreviatura, cuja omissão resultará na responsabilidade solidária e ilimitada dos administradores ${ }^{245}$. Se adotarem firma, esta deverá ser composta com o nome de um ou mais sócios, desde que pessoas físicas, se não individualizar todos os sócios, deverá conter o nome de pelo menos um deles, acrescido do aditivo "e companhia" e da palavra "limitada", por extenso ou abreviados.

No caso de denominação, deverá designar o objeto da sociedade, sendo permitido nela figurar o nome de um ou mais sócios.

Muito tem se criticado a exigência de que a denominação indique o objeto da sociedade, por se tratar de evidente retrocesso legislativo. Isso porque desde a revogação do art. 295 da Lei ${ }^{\circ}$ 556, de 25 de junho de 1850 (Código Comercial do Império) ${ }^{246}$ pelo Decreto $\mathrm{n}^{\circ}$ 916, de 24 de outubro de 1890, foi facultada a alusão ao objeto social na

\footnotetext{
${ }^{244}$ Nesse sentido, v. ProENÇA, José Marcelo Martins. Direito Comercial 1, 2a ed., São Paulo: Saraiva, 2008, p. 81

${ }^{245}$ Cf. art. 1.158 do CC
} 
denominação social das sociedades anônimas ${ }^{247-248}$. Regra similar foi prevista para a sociedade por quotas de responsabilidade limitada, criada pelo Decreto $\mathrm{n}^{\mathrm{o}} 3.708$, de 10 de janeiro de 1919 , visto que o parágrafo $1^{\circ}$ de seu art. $3^{\circ}$ dispunha que "[a] firma, quando não individualize todos os sócios, de conter o nome ou firma de um delles, devendo a denominação, quando possível, dar a conhecer o objectivo da sociedade".

A despeito da redação dúbia, que pode dar ensejo a interpretações divergentes quanto ao alcance da norma, é certo que a inclusão da expressão "quando possível" deve ser interpretada como atribuição de faculdade da sociedade, ou ainda como uma exceção à regra geral, quanto à indicação do objeto social, pois, caso contrário, não faria sentido sua incorporação no texto legal.

Posteriormente, a Lei $\mathrm{n}^{\mathrm{o}}$ 8.934, de 18 de novembro de 1994, que dispõe sobre o Registro Público de Empresas Mercantis e Atividades Afins, facultou, expressamente, a indicação do objeto no nome empresarial ${ }^{249}$.

A agudez das críticas quanto à obrigatoriedade de indicação do objeto social no nome empresarial das sociedades limitadas dá-se pelo fato de algumas sociedades possuírem objeto bastante amplo e diversificado, o que inviabilizaria a inclusão de todas as atividades no nome empresarial. Isso sem falar na necessidade superveniente de alterar o nome empresarial, no caso de a sociedade modificar seu objeto social, sob pena de vulneração do princípio da veracidade.

Neste sentido, tendo em vista recomendação da Associação Brasileira da Propriedade Intelectual ${ }^{250}$, o projeto de Lei $n^{\circ} 6.960$ de 2002, do então deputado Ricardo Fiúza, propôs nova redação ao $§ 2^{\circ}$ do art. 1.158, suprimindo tal obrigatoriedade ${ }^{251-252}$.

\footnotetext{
${ }^{246}$ Que previa expressamente a obrigatoriedade da indicação do objeto social na denominação, assim dispunha: "Art. 295. As companhias ou sociedades anonymas, designadas pelo objecto ou empreza a que se destinão, sem firma..."

${ }^{247} \mathrm{O}$ art. $4^{\circ}$ do Decreto no 916 estava assim redigido: "As companhias anonymas designar-se-hão por uma denominação particular ou pela indicação de seu objecto, não lhes sendo permittido ter firma ou razão social nem incluir na designação o nome por extenso ou abreviado de um accionista".

${ }^{248}$ Ressalte-se, também, que na época as denominações eram exclusivas das sociedades anônimas, visto que os demais tipos societários existentes por ocasião (sociedade em nome coletivo, sociedade em comandita simples e sociedade de capital e indústria) tinham necessariamente que ter firma, haja vista a responsabilidade pessoal dos sócios. As sociedades por quota de responsabilidade limitada somente foram introduzidas em nosso ordenamento jurídico cerca de três décadas depois com o Decreto $\mathrm{n}^{\mathrm{o}} 3.708$, de 10 de janeiro de 1919, cujo art. $3^{\circ}$ permitia-lhes o uso de denominação, nos seguintes termos: “Art. $3^{\circ}$. As sociedades por quotas, de responsabilidade limitada, adoptarão uma firma ou denominação particuar”. ${ }^{249}$ Cf. art. 35, III

${ }^{250}$ Cf. Resolução no 24, disponível em www.abpi.org.br/bibliotecas.asp?idiomas=Português\&secao=Resoluções\%20da\%20ABPI\&codigo=3\&resol ucao $=45$. Acesso em 22 de dezembro de 2008.

${ }^{251}$ Art. 1.158. omissis

$\S 2^{\circ}$ A denominação será composta por um ou mais elementos de fantasia, sendo permitido nela figurar o nome de um ou mais sócios, ou ainda o objeto da sociedade.
} 


\subsection{Sociedade anônima}

O Código Comercial de 1850 foi a primeira lei brasileira a tratar do nome das sociedades anônimas. Trazia, em seu art. 295, norma que determinava que tais sociedades fossem designadas pelo objeto ou empresa a que se destinavam, sendo proibida a firma social. Na época, não se imaginava que pudesse haver outra sociedade anônima para a mesma atividade, o que justificava designarem-se pelo objeto.

Mais tarde, a Lei $\mathrm{n}^{\circ} 3.150$, de 04 de novembro de 1882, promulgada por D. Pedro II, que regulava as companhias e sociedades anônimas, dispunha em seu art. $2^{\circ}$ que "[a]s companhias ou sociedades anonymas são determinadas ou por uma denominação particular ou pela designação do seu objeto. A designação ou denominação deve ser differente da de outra sociedade. Si fôr identica ou semelhante, de modo que possa induzir em erro ou em engano, a qualquer interessado assiste o direito de fazê-la modificar e de demandar perdas e damnos, causados pela identidade ou semelhança" 253. Logo, a denominação das sociedades anônimas poderia ser constituída por denominação particular ou pela designação de seu objeto, sendo expressamente vedado que tivessem firma ou razão social.

O Decreto $n^{\circ} 916 / 1890$, por sua vez, tratou da denominação das sociedades anônimas, contendo norma semelhante, que previa que tais sociedades designar-se-iam por uma denominação particular ou pela indicação de seu objeto, não lhes sendo permitido ter firma ou razão social, nem incluir na designação o nome por extenso ou abreviado de um acionista.

O Decreto n 2.627/1940 trouxe novas regras de formação do nome empresarial das sociedades anônimas (art. $3^{\circ}, \S \S 1^{\circ}$ e $2^{\circ}$ ), as quais foram praticamente reproduzidas na Lei $n^{\circ} 6.404 / 74$ que dispõe em seu art. $3^{\circ}$ que a sociedade será designada por denominação acompanhada das expressões "companhia" ou "sociedade anônima", expressas por extenso ou abreviadamente, mas vedada a utilização da primeira ao final. Inovou prevendo a possibilidade de figurar na denominação o nome do fundador, acionista, ou pessoa que por qualquer outro modo tenha concorrido para o êxito da empresa, em evidente exceção ao princípio da veracidade do nome empresarial (art. $\left.3^{\circ}, \S 1^{\circ}\right)$.

\footnotetext{
${ }^{252}$ Em 03/02/2004, a Comissão de Constituição e Justiça e de Cidadania da Câmara aprovou projeto substitutivo, de relatoria do deputado Vicente Arruda, o qual rejeitou a alteração proposta no $\S 2^{\circ}$ do art. 1.158. Porém, o projeto foi arquivado em 31/07/2007 tendo em vista o fim da legislatura, nos termos do art. 105 do Regimento Interno da Câmara dos Deputados, não tendo sido desarquivado.

${ }^{253}$ Redação mantida pelo Decreto n ${ }^{\circ} 8.821$, de 30 de dezembro de 1882 , art. $6^{\circ} \S \S 1^{\circ}$ e $2^{\circ}$.
} 
Se a denominação for idêntica ou semelhante à de companhia já existente, assistiria à prejudicada o direito de requerer a modificação, por via administrativa ou em juízo, e demandar as perdas e danos resultantes, nos termos do $\S 2^{\circ}$ do art. $3^{\circ}$, de Lei $n^{\circ} 6.404 / 74$.

Atualmente, as sociedades anônimas devem operar sob denominação designativa do objeto social, integrada pelas expressões "sociedade anônima" ou "companhia", por extenso ou abreviadamente. É o que dispõe o art. 1.160, do CC. Este artigo, a nosso ver, revogou o art. $3^{\circ}$ da Lei $n^{\circ}$ 6.404/76, que dava maior liberdade à formação das denominações, bem como obrigava o uso da expressão "companhia" ao final.

A alteração introduzida pelo CC merece crítica, pois limita sobremaneira a formação da denominação das sociedades anônimas, reinserindo em nosso ordenamento jurídico regra prevista na vetusta Lei $n^{\circ}$ 556/1850. Nem mesmo o Decreto no 916/1890 era tão restritivo, conquanto permitia o uso de uma “denominação particular", alternativamente à indicação do objeto social.

A nova regra causará, ainda, confusão entre as denominações das sociedades anônimas e as firmas ou razões sociais, já que suprimiu a obrigatoriedade, antes prevista no art. $3^{\circ}$ da Lei $n^{\circ}$ 6.404, do uso da expressão "companhia" ao início, permitindo, em seu silêncio, denominações terminadas em "companhia" tais quais as razões sociais.

Ademais, o art. 1.160 manteve a possibilidade de o nome do fundador, acionista, ou pessoa que por qualquer outro modo tenha concorrido para o êxito da empresa, poder figurar na denominação ${ }^{254}$.

\subsection{Sociedade em comandita por ações}

As sociedades em comandita por ações podem adotar ser firma ou denominação social. Conforme o art. 1.161, do Código Civil, pode, em lugar de firma, adotar denominação designativa do objeto social, aditada da expressão "comandita por ações".

A firma da sociedade em comandita por ações só poderá conter o nome de um ou mais sócios diretores ou gerentes, com o aditivo "e companhia", por extenso ou abreviado, acrescida da expressão "comandita por ações", por extenso ou abreviada. Caso opte por denominação, está deverá ser designativa de seu objeto social, bem como ser seguida da expressão "em comandita por ações", por extenso ou abreviada.

\footnotetext{
${ }^{254}$ Cf. art. $3^{\text {o }}$ da Lei ${ }^{\circ}$ 6.404/74 e art. 1.160, do CC
} 


\section{Grupos societários}

Existe um grupo societário quando diversas sociedades estão sob controle comum, usualmente exercido por uma sociedade constituída para esta finalidade específica, denominada holding ${ }^{255}$.

Segundo a IN $n^{\circ} 73$, de 28 de dezembro de 1998, do DNRC, o grupo de sociedades será constituído por convenção aprovada pelas sociedades que o componham, a qual deverá conter, a designação do grupo (art. $2^{\circ}$ ). Ainda, dispõe que a partir da data do arquivamento, a sociedade de comando e as filiadas passarão a usar os respectivos nomes empresariais acrescidos da designação do grupo (art. $4, \S 3^{\circ}$ ).

A IN n 104, do DNRC, reza que a expressão "grupo" é de uso exclusivo dos grupos de sociedades organizados, mediante convenção, na forma da Lei das Sociedades Anônimas. Após o arquivamento da convenção do grupo, a sociedade de comando e as filiadas deverão acrescentar aos seus nomes a designação do grupo (art. 13).

\section{Consórcios}

As sociedades, sob o mesmo controle ou não, podem constituir consórcio para executar determinado empreendimento. Neste caso, deverá ser firmado contrato de consórcio $^{256}$, que trará, obrigatoriamente, a designação do consórcio, se houver ${ }^{257}$.

\section{Sociedades estrangeiras}

A sociedade estrangeira, qualquer que seja seu objeto, não pode iniciar suas atividades antes de inscrita no registro próprio do lugar em que se deva estabelecer, devendo submeter-se previamente à aprovação do Poder Executivo. O art. 1.137, do CC, em seu parágrafo único, exige que a sociedade estrangeira funcione no território nacional com o nome que tiver em seu país de origem, podendo acrescentar as palavras "do Brasil" ou "para o Brasill".

Vale menção à IN no 78/1998, do DNRC, que disciplina o arquivamento de atos de Empresas Binacionais Brasileiro-Argentinas, a qual dispõe que os atos constitutivos das

\footnotetext{
${ }^{255}$ V. arts. 265 a 277, da Lei das Sociedades Anônimas

${ }^{256}$ V. art. 278, da Lei das Sociedades Anônimas

${ }^{257}$ Art. $2^{\circ}$, da IN n ${ }^{\circ} 74$, de 28 de dezembro de 1998.
} 
empresas Brasileiro-Argentinas deverão conter nome empresarial acrescido da expressão "Empresa Binacional Brasileiro-Argentina” ou as iniciais “E.B.B.A.” ou "E.B.A.B.”.

Encontramos disposição similar na IN no 104, também do DNRC, segundo a qual aos nomes das Empresas Binacionais Brasileiro-Argentinas deverão ser aditadas "Empresa Binacional Brasileiro-Argentinas", "EBBA" ou "EBAB" e as sociedades estrangeiras autorizadas a funcionar no Brasil poderão acrescentar os termos "do Brasil" ou "para o Brasil" aos seus nomes de origem.

\section{Outros entes associativos}

Vimos, linhas acima, que o parágrafo único do art. 1.155, do CC equipara a denominação das sociedades simples, associações e fundações, para fins de proteção, ao nome empresarial. Assim, cabe menção, ainda que sucintamente, ao nome das cooperativas, das sociedades de advogado e dos partidos políticos.

\subsection{Sociedade cooperativa}

As cooperativas não podem ter firma, sendo obrigatório o uso de denominação. Seu estatuto social deverá indicar denominação social contendo a expressão "cooperativa" 258. A denominação sempre deve ser acompanhada da expressão "Cooperativa", não podendo conter o termo "Banco" na formação de sua denominação social ${ }^{259}$.

Como a responsabilidade dos sócios nas cooperativas pode ser limitada ou ilimitada $^{260}$, algumas cooperativas passaram a incluir ao final de suas denominações o termo "limitada" ou sua abreviação "ltda.". As Juntas Comerciais recusaram-se, inicialmente, a permitir adição do termo "limitada" ou "ltda." na denominação das cooperativas, o que deu ensejo a discussões judiciais.

Tendo em vista precedentes judiciais, como a $\mathrm{AC} \mathrm{n}^{\text {o }}$ 1999.01.00.044725-7/DF ${ }^{261}$, no sentido de que "não há Lei que impeça o uso da denominação "limitada" às sociedades cooperativas. (...) A Lei $n^{0} 5.764 / 71$, lei de regência das cooperativas, distingue a responsabilidade dos sócios em limitada e ilimitada (artigos 11 e 12), razão maior para possibilitar a faculdade do registro com a utilização de tais denominações", o DNRC

\footnotetext{
${ }^{258}$ Cf. art. 21 da Lei $n^{\circ} 5.764$, de 16 de dezembro de 1.971

${ }^{259}$ Cf. art. $5^{\circ}$ da Lei $n^{\circ} 5.764 / 1.971$ e art. 1.159, do CC

${ }^{260}$ Cf. art. 1.095 , do CC.
} 
emitiu a Nota Técnica DNRC/COJUR/Nº 039/07, pacificando a questão, ao reconhecer que “diante do princípio de ser o nome, atributo de sua personalidade, onde deve espelhar, de pleno o que ela é, entendemos que, diante das inovações do novo Código Civil de 2002 e do próprio entendimento jurisprudencial, não há empecilho, na atualidade, de se aditar ao nome das Cooperativas o termos "limitada" ou "ltda." quando for o caso, isto é, quando composta por sócios com responsabilidade limitada ao valor do capital, principalmente, nas cooperativas de crédito".

\subsection{Sociedade de advogados}

A denominação das sociedades de advogados é regida pela Lei $n^{\circ} 8.906$, de 04 de julho de 1994. Depreende-se do art. 16 da referida lei que é obrigatório o uso de firma ou razão social, sendo expressamente vedado às sociedades de advogados o uso de denominação de fantasia ${ }^{262}$. A razão social deve ter, obrigatoriamente, o nome de, pelo menos, um advogado responsável pela sociedade, podendo permanecer o de sócio falecido, desde que prevista tal possibilidade no ato constitutivo ${ }^{263-264}$.

Como ensina PAUlo LôBo, "não há liberdade na composição do nome da sociedade de advogados. O nome deve expressar com clareza sua finalidade, não sendo admitidos nome de fantasia, símbolos ou acréscimos comuns nas atividades mercantis" ${ }^{265}$. E sobre a finalidade do referido dispositivo legal, assevera que "mesmo nos Estados Unidos, que admitem o modelo empresarial de sociedade de advogados, há forte recomendação do Código de Responsabilidade Profissional da American Bar Association (EC 2-11) no sentido da utilização dos nomes dos advogados associados, porque o uso de nome comercial 'pode desorientar os leigos acerca da identidade, responsabilidade e status dos advogados que a integram,", 266.

Esta possibilidade de permissividade quanto à permanência do nome do sócio falecido acaba por gerar confusão, pois, em se tratando de razão social, como diz a lei, dever-se-ia observar o princípio da veracidade, de modo que a razão social deveria, necessariamente, conter o nome apenas dos sócios efetivos. Ao passo que permite a

\footnotetext{
${ }^{261}$ TRF $1^{\text {a }}$ Região, $3^{\mathrm{a}}$ T. suplementar, AC 1999.01.00.044725-7/DF, j. 25.8.2005, 2005, DJ 23.09.2005.

${ }^{262}$ Lei no 8.906/1994, art. 16, caput

${ }^{263}$ Lei no $8.906 / 1994$, art. 16, § $1^{\circ}$.

${ }^{264}$ Ao contrário do que pode ocorrer nas sociedades de advogados, é expressamente proibida, nos demais tipos societários com exceção das sociedades anônimas (art. 1160 do CC), a manutenção na firma social do nome do sócio que vier a falecer, for excluído ou se retirar, cf. art. 1.165 do CC.

${ }^{265}$ LOBO, Paulo. Comentários ao Estatuto da Advocacia e da OAB. São Paulo: Saraiva: 2007, p. 122
} 
manutenção do nome do sócio falecido, descaracterizada está a razão social, de maneira que a Lei no 8.906/94 deveria falar em denominação. Nesse sentido, vale ressaltar que, além das sociedades de advogados, apenas às sociedades anônimas é possível manter em seu nome empresarial o nome de sócio falecido, já que se trata necessariamente de denominação, como expressamente exige a legislação ${ }^{267}$. Assim, podemos seguramente afirmar que o nome das sociedades de advogados não se trata de firma ou razão social, mas sim de denominação ${ }^{268}$.

No que concerne à manutenção do nome do sócio falecido, reza, neste sentido, o Provimento $n^{\circ}$ 112/2006, do Conselho Federal da Ordem dos Advogados do Brasil, em seu art. $2^{\circ}$, inc. I que o contrato social deverá conter: "razão social, constituída pelo nome completo, ou patronímico, dos sócios ou, pelo menos, de um deles, responsáveis pela administração, assim como a previsão de sua alteração ou manutenção, por falecimento de sócio que lhe tenha dado o nome, observado, ainda, o disposto no parágrafo único deste artigo".

Sobre a questão, EugÊNIO R. HADDOCK LOBO e Francisco Costa NetTo, afirmaram que sua função era "permitir que os terceiros identifiquem a sociedade de advogados pelo nome de seus componentes ou, pelo menos, de um deles, o responsável por ela" 269 .

Ainda em relação à formação da denominação das sociedades de advogados, o Provimento no 112/2006 dispõe que é permitido o uso do símbolo “\&”, como conjuntivo dos nomes de sócios que constarem da denominação social ( $\left.\operatorname{art.} 2^{\circ}, \mathrm{XI}\right)$, assim como que da razão social não poderá constar sigla ou expressão de fantasia ou das características mercantis, devendo vir acompanhada de expressão que indique tratar-se de Sociedade de Advogados, vedada a referência à "Sociedade Civil” ou "S.C.” (art. 2º parágrafo único).

Concluímos, assim, que as sociedades de advogados possuem denominação e não firma, embora sejam compostas pelo nome civil de seus sócios, gozando de exclusividade em todo o território nacional, ainda que o registro seja realizado em seccionais estaduais, por aplicação analógica das normas que tutelam os nomes comerciais ou de empresa. No

\footnotetext{
${ }^{266}$ Ibidem, p. 122/123

${ }^{267}$ Cf. art. $3^{\circ}$ da Lei ${ }^{\circ}$ 6.404/74 e art. 1.160, do CC

${ }^{268}$ JOÃO MARCOS SILVEIRA refere-se a uma denominação sui generis, sendo designadas, certamente, por denominação, mas por denominação que, particularmente, não pode ser de fantasia e deve conter o nome de pelo menos um dos sócios responsáveis pela sociedade, admitida a manutenção do nome do sócio falecido se manifestada sua concordância em vida (op. cit., p. 128).

${ }^{269}$ HadDOCK LOBO, Eugênio R. e Costa NeTto, Francisco. Comentários ao Estatuto da OAB e às Regras da Profissão do Advogado. Rio de Janeiro: Editora Rio, 1978, p. 171/172
} 
caso de homonímia entre os sócios, dever-se-á agregar à denominação posterior designação que o distinga ${ }^{270}$.

\subsection{Partidos políticos}

Cabe menção, também, aos partidos políticos, considerados pessoas jurídicas de direito privado ${ }^{271}$, cujos estatutos deverão conter o nome e a denominação abreviada do partido. Os partidos políticos terão, necessariamente, denominação, cuja exclusividade darse-á somente com o registro do respectivo estatuto no Tribunal Superior Eleitoral ${ }^{272}$, sendo expressamente vedada a utilização, por outros partidos, de variações que venham a induzir a erro ou confusão.

\section{A questão do nome dos condomínios edilícios}

Não obstante a ausência de personalidade jurídica dos condomínios edilícios, o que afasta o direito ao nome ${ }^{273}$, entendemos oportuno fazer-lhes referência, visto que, usualmente, têm nome.

É totalmente livre e facultativa a atribuição de nomes aos condomínios edilícios, assim como aos edifícios. Nesse sentido, interessante parecer sobre a questão, da lavra de José de OLIVEIRA ASCENSÃo ${ }^{274}$. Em suma, o jurista português tomando como premissa que o ato de atribuir nome a edifícios é uma atividade civil e não comercial, afastou qualquer infração a direitos de propriedade industrial ou prática de concorrência desleal.

A nosso ver, é acertado o entendimento de OLIVEIRA ASCENSÃo, de modo que o nome atribuído a um edifício não lhe confere exclusividade, pois não possui personalidade jurídica e, por conseguinte, direito ao nome. O mesmo entendimento aplica-se, a fortiori, em relação ao nome dos condomínios edilícios, que, usualmente, reproduzem o nome do próprio edifício. Por outro lado, o uso de marcas, ainda que famosas ${ }^{275}$, ou qualquer sinal

\footnotetext{
${ }^{270}$ No mesmo sentido v. SILVEIRA, Newton. Estudos e pareceres de propriedade intelectual, cit., p. 42, com a ressalva de que seus comentários foram realizados antes da entrada em vigor do vigente CC.

${ }^{271}$ Nesse sentido era expresso art. 16, inc. III do revogado CC/1.916, que não foi reproduzido no CC vigente.

${ }^{272}$ Cf. art. $7^{\circ}, \S 3^{\circ}$ da Lei 9.096 , de 19 de setembro de 1995, segundo o qual "somente o registro do estatuto do partido no Tribunal Superior Eleitoral assegura a exclusividade da sua denominação, sigla e símbolos, vedada a utilização, por outros partidos, de variações que venham a induzir a erro ou confusão".

${ }^{273}$ Cf. art. 44 c.c arts. 45 e 985 , do CC

274 OLIVEIRA ASCENSÃo, José de. Nome de edifício: conflito com marca, insígnia ou logotipo? In Cadernos de Direito de Marcas. OliveIRA, Maurício Lopes de (Coord.). Rio de Janeiro: Lumen Juris, 2007

${ }^{275}$ Referimo-nos às marcas famosas, nelas incluindo as marcas de alto renome e as marcas notoriamente conhecidas.
} 
distintivo alheio para compor o nome dado a um edifício, ou do próprio condomínio, não constitui infração a direitos de propriedade industrial, conquanto fora da atividade econômica $^{276}$.

\section{Outras regras de formação do nome}

\subsection{As empresas de pequeno porte e as microempresas}

A Lei Complementar no 123/06, que criou o "Simples Nacional", dispôs sobre o nome empresarial. Em seu art. 72, prevê que as microempresas e as empresas de pequeno porte ${ }^{277}$, nos termos da legislação civil, acrescentarão à sua firma ou denominação as expressões "Microempresa" ou "Empresa de Pequeno Porte", ou suas respectivas abreviações, "ME" ou "EPP”, conforme o caso, sendo facultativa a inclusão do objeto da sociedade, como também estabelece a IN n ${ }^{\circ} 104 / 2007$, do DNRC ${ }^{278}$.

Segundo a referida instrução normativa, as sociedades enquadradas como microempresa ou empresa de pequeno porte, inclusive quando o enquadramento se der juntamente com a constituição, quando adotarem denominação, é facultativa a inclusão do objeto da sociedade.

Ocorrendo o desenquadramento da sociedade da condição de microempresa ou empresa de pequeno porte, é obrigatória a inclusão do objeto da sociedade empresária no nome empresarial, mediante arquivamento da correspondente alteração contratual.

Tal preceito colide frontalmente com o art. 1.158, $\S 2^{\circ}$, do $\mathrm{CC}$, que trata da formação do nome empresarial das sociedades limitadas e, assim, exige que na denominação conste designação do objeto da sociedade. Ainda que se critique esta norma, tem total aplicação, enquanto não revogada. Assim, observados o disposto no art.72, da Lei Complementar $\mathrm{n}^{\mathrm{o}} 123 / 06$ e art. $1.158, \S 2^{\circ}$, do CC, entendemos que as sociedades limitadas

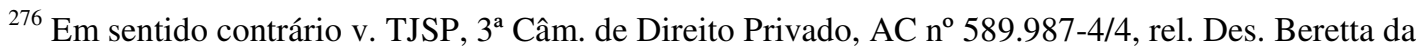
Silveira, j. 14/10/2008

${ }^{277}$ Nos termos do art. $3^{\circ}$, da Lei Complementar $n^{\circ} 123 / 2006$, consideram-se microempresas e empresas de pequeno porte, a sociedade empresária, a sociedade simples e o empresário individual, devidamente registrados no Registro de Empresas Mercantis ou no Registro Civil de Pessoas Jurídicas, conforme o caso, desde que no caso das microempresas aufira, em cada ano-calendário, receita bruta igual ou inferior a $\mathrm{R} \$$ 240.000,00 (duzentos e quarenta mil reais); e no caso das empresas de pequeno porte aufira, em cada anocalendário, receita bruta superior a $\mathrm{R} \$ 240.000,00$ (duzentos e quarenta mil reais) e igual ou inferior a $\mathrm{R} \$$ 2.400.000,00 (dois milhões e quatrocentos mil reais).

${ }^{278} \mathrm{Cf}$. art. 14. As microempresas e empresas de pequeno porte acrescentarão à sua firma ou denominação as expressões "Microempresa" ou "Empresa de Pequeno Porte", ou suas respectivas abreviações, "ME" ou "EPP".
} 
consideradas microempresas ou empresas de pequeno porte, enquanto perdurar este status, poderão deixar de designar o objeto social em sua denominação.

\subsection{As sociedades em recuperação judicial}

A Lei $n^{\circ}$ 11.101/2005, conhecida como Lei de Recuperação de Empresas e Falências, incorporou os principles and guidelines do Banco Mundial e mecanismos das mais modernas legislações sobre o tema, abandonando-se o procedimento liquidatório da empresa, substituindo-o por um meio solutório de recuperação de empresas. Foi suprimida a concordata e a introduzidas a recuperação judicial e extrajudicial.

Fundamentada na idéia institucionalista de preservação da empresa ${ }^{279}$, a recuperação judicial é um instituto colocado à disposição do devedor, que tem por objetivo permitir a superação de crise econômico-financeira, a fim de permitir a manutenção da fonte produtora, do emprego dos trabalhadores e dos interesses dos credores, promovendo, assim, a preservação da empresa, sua função social e o estímulo à atividade econômica.

Durante a execução do plano de recuperação, aprovado pelos credores e homologado pelo juiz, em todos os atos, contratos e documentos firmados pelo devedor ${ }^{280}$ sujeito ao procedimento de recuperação judicial deverá ser acrescida, após o nome empresarial, a expressão "em Recuperação Judicial" 281 .

\subsection{As instituições financeiras em liquidação}

Segundo a Lei ${ }^{\circ}$ 6.024, de 13 de março de 1974, estão sujeitas à intervenção ou à liquidação extrajudicial ${ }^{282}$, em ambos os casos efetuada e decretada pelo Bacen, as

\footnotetext{
${ }^{279}$ Salomão FILho, Calixto. In SouZa Junior, Francisco Satiro e PITOMBO, Antônio Sérgio A. de Morais (Coords.) Comentários à Lei de recuperação de empresas e falência: Lei 11.101/2005. São Paulo: Revista dos Tribunais, 2005, p. 48

${ }^{280}$ Entendendo-se por devedor, o empresário ou a sociedade empresária, nos termos do art. $1^{\text {o }}$, da Lei $11.101 / 2005$

${ }^{281}$ Cf. art. 69, da Lei no $11.101 / 2005$

${ }^{282}$ Dá-se a liquidação extrajudicial da instituição financeira (a) em razão de ocorrências que comprometam sua situação econômica ou financeira especialmente quando deixar de satisfazer, com pontualidade, seus compromissos ou quando se caracterizar qualquer dos motivos que autorizem a declararão de falência; (b) quando a administração violar gravemente as normas legais e estatutárias que disciplinam a atividade da instituição bem como as determinações do CMN ou do Bacen; (c) quando a instituição sofrer prejuízo que sujeite a risco anormal seus credores quirografários; ou (d) quando, cassada a autorização para funcionar, a instituição não iniciar, nos 90 dias seguintes, sua liquidação ordinária, ou quando, iniciada esta, verificar o Banco Central do Brasil que a morosidade de sua administração pode acarretar prejuízos para os credores
} 
instituições financeiras privadas e as públicas não federais, assim como as cooperativas de crédito.

Dado o interesse público envolvido, a referida Lei $\mathrm{n}^{\circ} 6.024 / 74$, prevê a que a instituição financeira, em todos os atos documentos e publicações de interesse da liquidação, será usada obrigatoriamente, a expressão "Em liquidação extrajudicial”, em seguida à denominação da entidade (art. 17). Neste mesmo sentido, a IN nº 104, do DNRC, estabelece que ao final dos nomes dos empresários e das sociedades empresárias que estiverem em processo de liquidação, após a anotação no Registro de Empresas, deverá ser aditado o termo "em liquidação" 283.

${ }^{283}$ Disposição similar era encontrada no art. 344, do C.Com., acerca da liquidação das sociedades mercantis 


\section{Capítulo IV \\ A PROTEÇÃO INTERNACIONAL DO NOME DE EMPRESA}

\section{O nome de empresa no orbe internacional}

O objeto deste trabalho, como já ressaltado, é analisar a proteção ao nome empresarial no Brasil, estando, portanto, excluída a análise da proteção dada ao nome empresarial em outros países. Até mesmo porque tal mister é de grande complexidade, o que exigiria um trabalho autônomo, haja vista a confusão verificada no ordenamento jurídico de diversos países quanto à natureza e conceito de nome empresarial ${ }^{284}$, o qual, comumente, é confundido com outros sinais distintivos do empresário, como as marcas, títulos de estabelecimento e insígnias. Em outras palavras, o conceito de nome comercial no direito comparado não se reporta a uma única e mesma realidade ${ }^{285-286}$.

Não obstante, independentemente da noção de nome comercial adotada no exterior, o certo é que, em razão de tratados internacionais ratificados pelo Brasil, o nome de empresário estrangeiro será protegido no Brasil, ao passo que o nome do empresário brasileiro tem proteção assegurada no exterior.

\section{Os tratados internacionais}

\subsection{A Convenção da União de Paris}

O nome comercial tem proteção internacional, mercê de tratado multilateral denominado Convenção da União de Paris ${ }^{287}$.

\footnotetext{
${ }^{284}$ Nesse sentido, v. GAMA CERQUeIRA, Tratado da Propriedade Industrial, cit., $\mathrm{n}^{\mathbf{o}} 186$.

${ }^{285}$ V. OlAVO, Carlos. Op. cit., p. 236 et seq.

${ }^{286}$ OLAVO sintetiza, com precisão, a questão, informando que "[e]m França, nome comercial é a denominação da empresa comercial, distinguindo-se assim da firma, sinal distintivo da pessoa do comerciante, quer em nome individual, quer pessoa colectiva. (...) A Alemanha não acolhe, no seu direito interno, o conceito de nome comercial. Existem, por um lado, a firma, sinal distintivo da pessoa do comerciante, e, por outro, o 'nome de estabelecimento' (geschaftsbezeichnung), que engloba todos os sinais distintivos, nominativos ou emblemáticos, dos estabelecimentos. (...) Em Itália, o nome comercial não corresponde a uma noção homogênea, pois engloba a firma e outros sinais distintivos. (...) Na Holanda, a noção de nome comercial abrange a denominação sob a qual a empresa é conhecida, protegida com base no respectivo uso" (in op. cit., p. 236/237)

${ }^{287}$ Vale dizer que, hoje, dúvida não há quanto à aplicação da CUP no Brasil, existindo diversos julgado, máxime do STJ, confirmando sua aplicação, citando-se, entre outros: $3^{\mathrm{a}}$ T., REsp 40.021/SP, Rel. Min. Carlos Alberto Menezes Direito, DJ 26.08.2002, p. 211; 4ª T., REsp 658.702/RJ, Rel. Min. Jorge
} 
De acordo com o art. $2^{\circ}$ da CUP, as pessoas nacionais de cada um dos países da União gozarão em todos os outros países da União, no que se refere à proteção da propriedade industrial, das vantagens que as leis respectivas concedem atualmente ou venham a conceder no futuro aos nacionais, sem prejuízo dos direitos especialmente previstos na presente Convenção.

Em consequência, terão a mesma proteção que estes e os mesmos recursos legais contra qualquer atentado dos seus direitos, desde que observem as condições e formalidades impostas aos nacionais. É o denominado Princípio do Tratamento Nacional.

A proteção da propriedade industrial abarca, evidentemente, o nome comercial (art. $1, \mathrm{n}^{\circ} 2$ ), razão pela qual o art. $8^{\circ}$ da CUP dispõe que “[o] nome comercial será protegido em todos os países da União sem obrigação de depósito ou de registro, quer faça ou não parte de uma marca ou de comércio".

Note-se que, dada as diferentes noções de nome comercial, o art. $8^{\circ}$ deve ser interpretado de maneira abrangente, i.e., considerando o conceito abrangente de nome comercial, como ensinou RAMELLA: "[e]l nombre comercial comprende ante todo el nombre bajo el cual se ejercita el comercio, el nombre civil se toma en consideración solamente cuando bajo el mismo alguno ejerce su industria. También se comprende la razón comercial ó forma y también la razón social. Por último la insignia ó muestra del estabelecimiento" ${ }^{288}$.

Esta proteção independe de registro ou qualquer formalidade, ainda que a legislação do país em que é reclamada disponha de outro modo ${ }^{289}$, bastando que o titular comprove a existência legal do nome comercial em seu país de origem. Portanto, para gozar de proteção nos demais países da União, é requisito inafastável que o nome comercial esteja protegido no país de origem. Nesse sentido vem sedimentando-se a jurisprudência do STJ ${ }^{290}$.

Scartezzini, j. em 29/06/2006, DJ 21/08/2006, p. 254; 4 T., REsp 331022/RJ, Rel. Min. Ruy Rosado de Aguiar, j. em 07/03/2002, DJ 06/05/2002, p. 296

${ }^{288}$ RAMELlA, Agustín. Tratado de la Propriedad Industrial, trad. Espanhola, t. II, 1913, p. 549

289 Cf. GAMA CERQUeIRA, Tratado da Propriedade Industrial, cit., p. 449

${ }^{290}$ V. Recurso especial. Nome inapropriável. Expressão de uso comum. Precedentes.

1. A proteção ao uso do nome dispensa, até mesmo, o registro, diante da necessidade de preservar a identidade da empresa nas suas relações com a clientela. 2. Mesmo que a expressão seja de uso comum não é possível, se anteriormente identifica determinada empresa, usá-la em outra, sob o argumento de ser inapropriável. 3. Recurso conhecido e provido. (STJ, $3^{\mathrm{a}}$ T., REsp 65.002/SP, Rel. Min. Carlos Alberto Menezes Direito, DJ 02.09.2002 p. 182; nosso grifo); Nome comercial. Marca. Exclusividade. Prescrição. 1. $\mathrm{Na}$ linha de precedentes da Corte, a proteção pura e simples ao uso do nome comercial ou marca tem prescrição vintenária, mas o ressarcimento do dano causado pelo uso indevido tem prescrição qüinqüenal, a contar da data em que se deu a ofensa ou o dano. 2. O nome comercial deve ser protegido, nos termos da Convenção de Paris, vigente no Brasil, até mesmo na ausência de qualquer registro. 3. A marca 
Questão interessante é quanto ao objeto da proteção, haja vista disparidade de noção legal do nome comercial (restritiva ou abrangente) nos mais diversos países. Prevalece a noção do país em que é reclamada a proteção ou do país do registro primígeno?

A nosso ver, ao menos no Brasil, deve prevalecer a noção legal aqui adotada ${ }^{291-292}$, sob pena dar desigual tratamento ao estrangeiro, o que violaria o princípio da isonomia ${ }^{293}$, previsto no art. $5^{\circ}$, caput, da Constituição Federal, segundo o qual "todos são iguais perante a lei, sem distinção de qualquer natureza". Assim, a proteção do nome comercial estrangeiro, reivindicada através do art. $8^{\circ}$ da CUP, será aquela que a lei brasileira concede aos nomes de empresa nacionais.

\subsection{O TRIPs}

O TRIPs não se refere especificamente aos nomes comerciais. Todavia, expressamente incorporou os artigos 1 a 12, e 19, da CUP, nos termos de seu art. $2^{\circ}$, de modo que todos os países signatários estão obrigados, por conseguinte, a assegurar proteção ao nome comercial, independentemente de registro, sob pena de descumprimento das normas da OMC.

Ademais, há no TRIPs uma única referência ao nome usado no comércio, na seção 3, que trata das indicações geográficas. Segundo o art. 24, n 8. “[a]s disposições desta

devidamente registrada deve ser protegida, não se podendo impedir o detentor do registro de usá-la com exclusividade. 4. Recurso conhecido e provido, em parte. (STJ, $3^{\mathrm{a}}$ T., REsp 40.021/SP, Rel. Min. Carlos Alberto Menezes Direito, DJ 26.08.2002 p. 211); Nome comercial. Marca. Convenção de Paris.

Representação processual: regularização. Sustentação oral: Repetição. Competência. Precedentes da Corte. 1. Nome comercial e marca não se confundem, sendo a proteção do primeiro, na linha de precedentes da Corte, oferecida pelo art. $8^{\circ}$ da Convenção de Paris, independentemente de qualquer registro. (...) 6. Recurso especial não conhecido. (STJ, $3^{\mathrm{a}}$ T., REsp 152.243/SP, Rel. Min. Carlos Alberto Menezes Direito, DJ 08.03.1999 p. 219; nossos grifos); Nome comercial. Proteção decorrente do disposto no artigo $8^{\circ} \mathrm{da}$ Convenção da União de Paris. Desnecessidade de que haja sido feito o registro no Brasil. Marca - Registro. Não se pode vedar o uso a quem é titular do registro. A anulação desse haverá de ser pleiteada em ação direta (STJ, $3^{\text {a }}$ T., REsp no 36.898-SP, Rel. Min. Eduardo Ribeiro, DJ de 28/03/94); Propriedade Industrial. Nome comercial. “AUDI". Caução do art. 835 do CPC. - Não acarreta a nulidade do processo o depósito tardio da caução exigida pelo art. 835 do CPC, falta que não prejudicou o processo nem causou dano à parte adversa. O nome Audi, de titularidade de empresa estrangeira, tem proteção no Brasil por força de tratados internacionais. Recurso não conhecido. (STJ, $4^{\mathrm{a}}$ T., REsp 331022 / RJ, rel. Min. Ruy Rosado de Aguiar, DJ de 06/05/2002, p. 296; nossa sublinha)

${ }^{291}$ Em sentido contrário LADAS, Stephen P. La protection internationale de la propriété industrielle, Paris : E. de Boccard, 1933, p. 720

${ }^{292}$ Nesse sentido, "a proteção ao nome estrangeiro deve ser requerida nos moldes estabelecidos pela lei nacional, conforme interpretação sistemática da Convenção da União de Paris.”, cf. STJ, 4ª T., REsp 555.086/RJ, Rel. Min. Jorge Scartezzini, j. em 14/12/2004, DJ 28/02/2005, p. 327

${ }^{293}$ Que "constitui o signo fundamental da democracia", destaca José Afonso da SILVA (in Curso de Direito Constitucional Positivo, $15^{\mathrm{a}}$ ed., São Paulo: Malheiros Editores, 1998). 
Seção não prejudicarão de forma alguma o direito de qualquer pessoa de usar, em operações comerciais, seu nome ou o de seu predecessor no negócio, exceto quando esse nome for utilizado de maneira que induza o público a erro".

Em outras palavras, as normas sobre as indicações geográficas não poderão prejudicar o direito de qualquer pessoa de usar seu nome civil, em atividade comercial, salvo se houver suscetibilidade de indução do público em erro.

\section{O nome comercial no Mercosul}

O Tratado de Assunção, subscrito pela Argentina, Brasil, Uruguai e Paraguai, em 26 de março de 1.991, criou o Mercado Comum do Sul, conhecido como Mercosul, com o objetivo incrementar o comércio, ampliando as dimensões dos respectivos mercados nacionais através do estabelecimento de uma área de livre comércio.

Este Tratado foi ratificado pelo Congresso através do Decreto Legislativo no 197 , de 25 de setembro de 1.991 e promulgado pelo Decreto $\mathrm{n}^{\mathrm{o}} 350$, de 21 de novembro de 1.991.

Os quatro países ratificaram-no, de modo que o tratado entrou em vigor em 29 de novembro de 1.991. Posteriormente, foi assinado o Protocolo de Ouro Preto, promulgado pelo Decreto $\mathrm{n}^{\circ} 1.901$, de 09/05/1996, trazendo mudanças institucionais ao bloco.

O Tratado de Assunção não trata especificamente de propriedade industrial, a qual é objeto, tão-somente, da decisão MERCOSUL/CMC/DEC. $\mathrm{n}^{\circ}$ 8/95, do Conselho do Mercado Comum, que aprovou o Protocolo de Harmonização de Normas sobre Propriedade Intelectual no Mercosul, em Matéria de Marcas, Indicações de Procedência e Denominações de Origem.

Este protocolo, em seu art. 24, estabeleceu o compromisso de os Estados Partes realizarem esforços no sentido de concluir, no menor prazo possível, acordos adicionais sobre patentes de invenção, modelos de utilidade, desenhos industriais, direitos de autor e conexos, e outras matérias relativas à propriedade intelectual, o que incluiria o nome comercial. Contudo, se próprio Protocolo de Harmonização, aprovado há mais de dez anos, jamais entrou em vigor, quanto menos foram concluídos acordos adicionais acerca das demais matérias relacionadas à propriedade intelectual. 
Desta forma, a proteção do nome comercial dá-se nos termos da CUP, da qual praticamente todos os países da América do Sul são membros ${ }^{294}$.

Existem, ainda, acordos bilaterais, como a Convenção para a proteção das marcas de fábrica, comércio ou agricultura e dos nomes comerciais, assinada em Santiago do Chile, em 1923, aprovada pelo Decreto do Poder Legislativo DPL no 4.810, de 12 de janeiro de 1924, bem como os Convênios sobre Marcas de Indústria e de Comércio e Privilégio de Invenção, entre Brasil e Uruguai (DPL nº 1, de 1950) e Panamá (DPL 15, de 1950), que estabelecem que o nome comercial será protegido em qualquer dos Estados Contratantes, sem obrigação de depósito ou registro, faça, ou não, parte de marca de indústria ou de comércio, uma vez provada a existência legal da firma ou sociedade do país de origem e sempre de acordo com a legislação interna.

\section{O nome comercial no NAFTA}

O Tratado de Livre Comércio da América do Norte, ou North América Free Trade Agreement, em sua sexta parte, destinada à Propriedade Intelectual, não faz menção expressa à proteção ao nome empresarial. Pelo contrário, define direitos de propriedade intelectual, para efeitos do tratado, como se referindo somente a direitos de autor e direitos conexos, direitos de marcas, direitos de patente direitos de topografias de circuitos integrados, direitos de segredos industriais e de negócios, direitos dos obtentores de cultivares, direitos das indicações geográficas e direitos de desenhos industriais (art. 1721, 2)

Contudo, em seu art. 1.701, item 2, alínea "c", impõe às partes contratantes a aplicação das disposições da CUP (revisão de Estocolmo de 1967), que em seu art. $8^{\circ}$, como já ressaltado, tutela explicitamente os nomes empresariais.

Ademais, com relação às marcas, veda o tratado o registro de marcas que contenham ou consistam em elementos que possam levar à confusão com terceiros (art. $\left.1.708, \mathrm{n}^{\circ} 14\right)$, de modo que se dessume proteção reflexa do nome empresarial.

\footnotetext{
${ }^{294}$ Com exceção da Venezuela que, em abril de 2006, denunciou ao Pacto ou Comunidade Andino (nome pelo qual é conhecido o Acordo de Cartagena, firmado em 1969, por Bolívia, Colômbia, Equador, Peru e Venezuela) deixando de aplicar, em 17 de setembro de 2008, a Decisão 486 do Acordo, o que acarretou a repristinação da Lei de Propriedade Industrial de 1955, implicando na retirada do país da CUP e do Acordo TRIPS.
} 


\section{Capítulo V \\ A TUTELA DO NOME EMPRESARIAL}

\section{Evolução histórica da proteção ao nome empresarial no Brasil}

Até a metade do século XIX não havia no Brasil legislação sobre o nome empresarial. O Código Comercial do Império (Lei $\mathrm{n}^{\mathrm{o}}$ 556, de 25 de junho de 1850) foi a primeira lei a deliberar sobre as firmas e denominações dos comerciantes e sociedades $\operatorname{anônimas~}^{295}$.

A Lei $\mathrm{n}^{\mathrm{o}} 3.150$ de 04 de novembro de $1882^{296}$, promulgada por D. Pedro II, que regulava as companhias e sociedades anônimas, inclusive quanto às suas denominações sociais. Dispunha em seu art. $2^{\circ}$ que "[a] as companhias ou sociedades anonymas são determinadas ou por uma denominação particular ou pela designação do seu objeto. A designação ou denominação deve ser differente da de outra sociedade. Si fôr identica ou semelhante, de modo que possa induzir em erro ou em engano, a qualquer interessado assiste o direito de fazel-a modificar e de demandar perdas e damnos, causados pela identidade ou semelhança" ${ }^{297}$. Era, ainda, expressamente vedado que tivessem firma ou razão social.

Em 20 de março de 1883 é promulgada a Convenção da União de Paris para Proteção da Propriedade Industrial ${ }^{298}$, resultado da conferência diplomática realizada em Paris em $1880^{299}$. Em seu art. $8^{\circ}$ previa a CUP que: "a trade name shall be protected in all the countries of the Union without the obligation of filing or registration, whether or not it forms part of a trademark" 300 .

$\mathrm{O}$ aludido artigo $8^{\circ}$ previu que o nome comercial deveria ser protegido, sem especificar, contudo, como tal proteção deveria ser dada. Assim, os Estados-Membros

\footnotetext{
${ }^{295}$ Vide artigos $5^{\circ}$ e 295 desta Lei.

${ }^{296}$ Regulamentada pelo Decreto 8.821 , de 30 de dezembro de 1882

${ }^{297}$ Redação mantida pelo referido Decreto $n^{\circ} 8.821 / 1882$, art. $6^{\circ} \S \S 1^{\circ}$ e $2^{\circ}$.

${ }^{298}$ Promulgada entre nós pelo Decreto $\mathrm{n}^{\circ}$ 9.233, de 28 de junho de 1884

${ }^{299}$ Cf. G .H. C. BODENHAUSEN, in Guide to the application of the Paris Convention for the Protection of Industrial Property as revised at Stockholm in 1967, p. 9

${ }^{300}$ Em português: "[o] nome comercial será protegido em todos os países da União sem obrigações de depósito ou de registro, quer faça ou não parte de uma marca de fábrica ou de comércio", cf. Decreto $\mathrm{n}^{\circ}$ 75.572, de 8 de abril de 1975 .
} 
estariam livres para regular tal proteção através de legislação específica, pela legislação de repressão à concorrência desleal ou por qualquer outro meio considerado apropriado ${ }^{301}$.

$\mathrm{Na}$ esteira da proteção prevista na CUP, surge, então, a Lei no 3.346 de 14 de outubro de 1887, promulgada pela Princesa Imperial Regente, em nome do Imperador, trazendo certa proteção ao nome comercial. Estabelecia, em seu art. 8 , item $2^{\circ}$, que era vedado o registro de marca (cuja competência era, na época, das Juntas Comerciais) que contivesse ou consistisse em nome comercial ou firma social de que legitimamente não possa usar o requerente. Esta lei previa, inclusive, a possibilidade da propositura de ação declaratória da nulidade do registro de marca ${ }^{302}$ que infringisse nome comercial alheio ${ }^{303}$, bem como tipificava como crime o uso de nome ou firma comercial de outrem, fazendo ou não parte de marca registrada ${ }^{304}$, sob pena de prisão de um a seis meses e multa ${ }^{305}$.

Até então, vigorava nossa primeira lei de $\operatorname{marcas}^{306}$, a qual apenas dispunha que a marca poderia consistir no nome do fabricante ou negociante, no da firma ou razão social, ou qualquer outra denominação que pudessem distinguir produtos ou objetos no comércio.

Somente com o Decreto 916, de 24 de outubro de 1890, decretado pelo Gen. Manoel Deodoro da Fonseca, Chefe do Governo Provisório da República, foi criado o registro das firmas ou razões comerciais, a cargo das Juntas Comerciais e das Inspetorias Comerciais. Não obstante dissesse o decreto que o registro das firmas ou razões sociais era facultativo, na prática era necessário, pois sem o registro as formalidades exigidas pelo Código Comercial não poderiam ser atendidas. Definia o decreto, em seu art. $2^{\circ}$, que firma ou razão comercial é o nome sob o qual o comerciante ou sociedade exerce o comércio e assina-se nos atos a ele referentes. Apenas as sociedades anônimas deveriam designar-se por uma denominação particular ou pela indicação de seu objeto, não lhes sendo permitido ter firma ou razão social, nem incluir na designação o nome por extenso ou abreviado de um acionista.

\footnotetext{
${ }^{301}$ Cf. G .H. C. Bodenhausen, in Guide to the application of the Paris Convention..., p. 133. E continua o autor: "[a] trade name will be protected, according to the Article under consideration, without any obligation of filing or registration, which means that, in the country where its protection is claimed, filing or registration of the trade name may be required neither in that country nor in any country, particularly in the country of origin of the trade name, even if registration is mandatory there. If the legislation of a country subjects the protection of national trade names to registration, the provision under discussion will mean a derogation from such obligation in favor of foreign trade names” (op. cit., p. 134).

${ }^{302}$ Para tanto, era necessário comprovar o uso anterior do nome comercial, ainda que não registrado, e observar o prazo prescricional de seis meses, contado do registro da marca.

${ }^{303}$ Cf. Lei $n^{\circ} 3.346 / 1887$, art. 11

${ }^{304}$ Interessante a minudência da lei ao dispor que "reputar-se-a existente a usurpação de nome ou firma commercial, de que trata o n. ${ }^{\circ}$ 7, quer a reprodução seja integral, quer com acrescentamentos, omissões ou alterações, contanto que haja a mesma possibilidade de confusão do comprador" (art. 14).

${ }^{305}$ Cf. Lei no $3.346 / 1887$, art. 14 , item $7^{\circ}$
} 
O Decreto $n^{\circ} 916$ assegurava o direito de quem exercesse o comércio fazer registrar ou inscrever a firma ou razão comercial no registro da sede do estabelecimento principal, podendo inscrevê-la também na sede dos estabelecimentos filiais. Note-se, também, que já previa o decreto o princípio da novidade, dispondo que toda firma nova deveria se distinguir de qualquer outra que exista inscrita no registro do lugar. Se o comerciante tivesse nome idêntico ao de outro já inscrito, deveria acrescentar designação que o distinguisse. Merece menção, outrossim, seu art. 10, segundo o qual "[o] emprego ou uso illegal de firma registrada ou inscripta dará direito ao dono de exigir a prohibição desse uso e a indemnização por perdas e danos, além da acção criminal que no caso couber".

A Lei de Marcas de $1904^{307}$ previa o registro, como marca, de firma ou razão social, perante a Junta ou Inspetoria Comercial, prevendo, também, punição, com pena de prisão e multa, para quem usasse de nome ou firma comercial que lhe não pertencesse, fizesse ou não parte de marca registrada ${ }^{308}$.

O Decreto $\mathrm{n}^{\mathbf{0}} 3.708$, de 10 de janeiro de 1919, veio a lume para regular as sociedades por quotas de responsabilidade limitada, as quais deveriam adotar "firma ou denominação particular", sendo que a firma, quando não individualize todos os sócios, deveria conter o nome ou a firma de um deles, devendo a denominação, quando possível, dar a conhecer o objetivo da sociedade ${ }^{309}$.

Com o Decreto n ${ }^{\circ}$ 16.264, de 19 de dezembro de 1923, é criada a Diretoria Geral da Propriedade Industrial, que tinha a seu cargo o registro de marcas. O regulamento deste decreto dispunha que não podiam gozar de proteção as marcas de indústria e comércio que contivessem nome comercial ou firma social de que legitimamente não pudesse usar o requerente ${ }^{310}$.

Em 29 de junho de 1934, é publicado o Decreto n ${ }^{\circ} 24.507$, que criou o registro do nome comercial e do título de estabelecimento, a cargo do Departamento Nacional da Propriedade Industrial, dando-lhe caráter facultativo. Tal registro, dizia o art. 25, não substitui nem precede às formalidades prescritas pela legislação em vigor relativamente às firmas ou razões comerciais, e só protege o seu titular, quanto ao uso exclusivo em papéis de correspondência, contabilidade, impressos e outros quaisquer meios de propaganda,

\footnotetext{
${ }^{306}$ Decreto $\mathrm{n}^{\mathrm{o}} 2.682$, de 23 de outubro de 1875

${ }^{307}$ Lei ${ }^{\circ} 1.236$, de 24 de setembro de 1904

${ }^{308}$ Cf. art. $13, \mathrm{n}^{\circ} 9$

${ }^{309}$ Cf. art. $3^{\circ}, \S \S 1^{\text {o e }} 2^{\text {o }}$

${ }^{310} \mathrm{Cf}$. art. $80, \mathrm{n}^{\circ} 3^{\circ}$. Cabe aqui mencionar que na obra de GAMA CERQUEIRA há alusão equivocada ao $\mathrm{n}^{\circ} 4$ do referido art. 80, que tratava das indicações de procedência (op. cit., vol. I, p. 510). Certamente o ilustre tratadista quis referir-se ao $\mathrm{n}^{\circ} 3$, que versava, como dito, sobre o nome comercial.
} 
bem como em veículos, edifícios, tabuletas e outros locais, exceto nas mercadorias que forem objeto da indústria, comércio ou atividade de seu titular ${ }^{311}$.

Segundo WALDEMAR FERREIRA, o Decreto no 24.507 "rompendo com a boa doutrina e com a erronia de palmatória, considerou o nome comercial apenas o título de estabelecimento. Retrocedendo, a fim de pôr-se, quanto a isso, no bom caminho, o art. 104 do Decreto-lei n. ${ }^{\circ}$ 7.903, de 27 de agôsto de 1945, que instituiu o Código da Propriedade Industrial, conceituou o nome comercial à firma ou denominação, adotada pela pessoa, natural ou jurídica, para o exercício de atividades comerciais, industriais ou agrícolas" 312313

No interregno entre o Decreto $n^{\circ}$ 24.507/1934 e o Decreto-lei n. $^{\circ}$ 7.903/1945 foi promulgado o Decreto-Lei $\mathrm{n}^{\circ} 2.627$, de 26 de setembro de 1940, o qual dispunha sobre as sociedades por ações e, inclusive, sobre sua denominação, parte em que foi posteriormente revogado pela Lei $\mathrm{n}^{\circ}$ 6.404/1976, que manteve praticamente o mesmo texto sobre a obrigatoriedade da adoção de denominação, e regras sobre sua formação ${ }^{314}$.

Destaca-se que a Constituição Federal de 1946 erigiu a proteção ao nome comercial ao patamar dos direitos e garantias individuais, prevendo em seu art. $141 \S 18$ que "é assegurada a propriedade das marcas de indústria e comércio, bem como a exclusividade do uso do nome comercial".

A Constituição subseqüente, de 1967, manteve expressamente essa proteção, em seu art. 150, § 24, segundo o qual “a lei garantirá aos autores de inventos industriais privilégio temporário para sua utilização e assegurará a propriedade das marcas de indústria e comércio, bem como a exclusividade do nome comercial”. Tal proteção foi mantida pela Emenda Constitucional no 1, de 17 de outubro de 1969, que modificou o texto da Constituição Federal de 1967, passando a previsão de proteção ao nome comercial para o art. $153, \S 24$.

\footnotetext{
${ }^{311}$ GAMA CERQUEIRA fez uma aguda crítica, aduzindo que "dez anos de experiência vêm demonstrando a inutilidade e os inconvenientes do registro de firmas comerciais e denominações de sociedades instituído por êste decreto, o qual tem servido, apenas, para criar questões complicadas resultantes da duplicata de registros independentes feitos no Departamento Nacional da Propriedade Industrial e nas Juntas Comerciais e Registros de Comércio dos Estados (op. cit., p. 510, nota 55). Pertinente a crítica de GAMA CERQUEIRA, pois o direito de exclusividade, nos termos do art. 25 do Decreto, já decorria da adoção da firma ou denominação. ${ }^{312}$ FERREIRA, Waldemar. Tratado de Direito Comercial, São Paulo: Saraiva, 1962, sexto volume, 177/178

${ }^{313}$ Digno de nota que o Decreto-lei n. 7.903 equiparou ao nome comercial as denominações das sociedades civis e das fundações, além de considerar no conceito de nome comercial o nome das pessoas físicas ou jurídicas que exercem atividades agrícolas (cf. art. 104 e parágrafo único)

${ }^{314}$ V. art. $3^{\circ}$ do Decreto-Lei ${ }^{\circ}$ 2.627/1940 e art. $3^{\circ}$ da Lei n ${ }^{\circ} 6.404 / 1976$
} 
Vale mencionar o Decreto-Lei $\mathrm{n}^{\circ} 4.726$, de 13 de julho de 1965, que dispunha sobre os Serviços do Registro do Comércio e Atividades afins. Este decreto previa o registro dos nomes comerciais das sociedades mercantis, exceto das sociedades anônimas.

Interpretando a legislação até então vigente, asseverou NEWTON SILVEIRA que: "a proteção ao nome comercial independe de registro, consoante o disposto no art. 8 da Convenção de Paris (Revisão de Haia - Dec. n. 19.056, de 31-12-1929, invocável pelos nacionais na forma do art. $4^{\circ}$ do CPI). Independe de registro, também, no caso das sociedades por ações, visto que sua denominação não é objeto do registro previsto no art. 37, III, 7º da Lei n. 4.726, de 1965 (verbis: 'Art. 37. O Registro do Comércio compreende:... III - o registro:... 7..$^{\circ}$ ) de nomes comerciais das sociedades mercantis, exceto das sociedades anônimas'). Embora não registrada, a denominação da sociedade anônima goza da exclusividade prevista na Constituição, já que consagrada pela lei específica (Dec.-lei n. 2.627, de 1940, art. $3^{\circ}, \S 2^{\circ}$, reiterado no parágrafo e artigo dos mesmos números da Lei n. 6.404, de 1976). Essa exclusividade opera em todo o território nacional, já que a lei não a limita, nem condiciona seu exercício a qualquer formalidade de caráter estadual ou nacional $\mathrm{O}$ mesmo se aplica às sociedades por quotas, em virtude de expressa remessa do art. 18 do Decreto n. 3.708, de 1919, à Lei das Sociedades por Ações. Dessa forma, pouco importa as disposições de caráter restrito ao território do registro do comércio previstas nos arts. $6^{\circ}$ do Decreto n. 916, de 1890, 38, IX, da Lei n. 4.726, de 1965, e 71, IX, do Decreto n. 57.561, de 1966 (bem como o registro de extensão da proteção do nome comercial criado pela Portaria DNRC n. 1, de 1974), que devem ser entendidas como normas reguladoras das atividades das Juntas Comerciais e não como constitutivas do direito subjetivo ao nome comercial" ${ }^{315}$.

O Código da Propriedade Industrial de $1967{ }^{316}$ substituiu a expressão nome comercial por nome de empresa, passando a defini-lo como "a firma ou denominação adotada por pessoa física ou jurídica e pela qual é designada, no exercício de suas atividades industriais, comerciais, extrativas, agrícolas ou de prestação de serviços". Notese que pela primeira vez em nossa legislação o nome empresarial foi expressamente estendido à prestação de serviços ${ }^{317}$. A despeito das críticas doutrinárias, o Código de 1967 manteve o registro do nome empresarial no Departamento Nacional da Propriedade Industrial, para que tivesse proteção nacional.

\footnotetext{
${ }^{315}$ SILVEIRA, Newton. Licença de uso de marca e outros sinais distintivos, p. 55/56

${ }^{316}$ Decreto-Lei no 254 , de 28 de fevereiro de 1967

${ }^{317}$ Art. 90 do Decreto-Lei no 254 , de 28 de fevereiro de 1967
} 
O Decreto-Lei $\mathrm{n}^{\circ} 1.005$, de 21 de outubro de 1969, finalmente, extinguiu o registro dos nomes empresariais, dispondo que "a proteção ao nome comercial ou de emprêsa, em todo o território nacional, é adquirida através do arquivamento ou registro dos atos constitutivos da firma ou sociedade no Registro do Comércio ou no Registro Civil das pessoas jurídicas, conforme o caso" 318.

Pondo fim a esta breve digressão histórica acerca das bases legislativas da proteção ao nome empresarial, cabe menção ao nosso último Código da Propriedade Industrial, Lei $\mathrm{n}^{\mathrm{o}}$ 5.772, de 21 de dezembro de 1971, que manteve extinto o registro dos nomes empresariais, nos seguintes termos: "o nome comercial ou de empresa e o título de estabelecimento continuarão a gozar de proteção, através de legislação própria, não se lhes aplicando o disposto neste Código" ${ }^{319}$. Contudo, a legislação própria nunca se engendrou.

\section{Legislação em vigor aplicável ao nome de empresa no Brasil}

Hodiernamente, a proteção ao nome empresarial carece de lei específica, havendo disposições esparsas em diversos diplomas legais, notadamente: 1) a Convenção da União de Paris ${ }^{320}$; 2) a Constituição Federal de $1988^{321}$; 3) o Código de Defesa do Consumidor $^{322}$; 4) a Lei de Registro Público de Empresas Mercantis e Atividades Afins ${ }^{323}$ e seu regulamento o Decreto $\mathrm{n}^{\mathrm{o}} 1.800 / 96$; 5) a Lei da Propriedade Industrial ${ }^{324}$; e, finalmente, 6) o Código Civil.

Esta dispersão de dispositivos sobre o nome de empresa dificulta não só a compreensão do instituto, mas também sua efetiva proteção. Para facilitar o entendimento, podemos dividir a legislação em dois grupos: o primeiro traz as normas referentes ao nome empresarial em sua função identificadora (ou subjetiva), especificamente a Lei de Registro Público de Empresas Mercantis e o Código Civil; ao passo que no segundo encontram-se as normas que tratam da função econômico-concorrencial (ou objetiva) do nome

\footnotetext{
${ }^{318}$ Cf. art. 166

${ }^{319}$ Cf. art. 119

${ }^{320}$ Art. $8^{\circ}$, aplicável entre nós desde 1884 (Dec. $n^{\circ}$ 9.233/1.884), estando atualmente em vigor a Revisão de Estocolmo de 1967, promulgada pelo Decreto $n^{\circ}$ 635, de 21 de agosto de 1992 (DOU de 24/08/1992) e ratificada a declaração de adesão aos arts. $1^{\circ}$ a 12 e ao art. 28, alínea 1, pelo Decreto $n^{\circ} 1.263$, de 10 de outubro de 1994 (DOU de 13/10/1994)

${ }^{321}$ Cf. art. $5^{\circ}$, XXIX

${ }^{322}$ Lei $n^{\circ} 8.078 / 90$, art. $4^{\circ}$, VI

${ }^{323}$ Lei no $8.934 / 94$, arts. 33, 34 e 35

${ }^{324}$ Lei n $^{\circ} 9.279 / 96$, arts. $124, \mathrm{~V}, 191$ e $195, \mathrm{~V}$
} 
empresarial. Este grupo compreende a Convenção da União de Paris, a Constituição Federal de 1988, o Código de Defesa do Consumidor e a Lei da Propriedade Industrial.

Assim, existem normas que disciplinam a proteção do nome de empresa em sua função identificadora (ou subjetiva) e outras relativas à função econômico-concorrencial (ou objetiva) do nome ${ }^{325}$.

Desempenhando sua função identificadora, o nome empresarial, como já vimos, constitui um direito e uma obrigação do empresário, haja vista o interesse público latente, consistente no interesse social de identificação do sujeito de direitos e obrigações. Nesse sentido, o CC contém capítulo específico sobre o nome empresarial ${ }^{326}$ (artigos 1.155 a 1.168), trazendo dispositivos sobre as regras de formação das firmas e denominações (artigos 1.156 usque 1.162) do empresário e tipos societários, como vimos no $\mathrm{n}^{\circ} 4$ supra, e disposições gerais sobre quanto à aplicação do princípio da novidade ${ }^{327-328}$, do princípio da veracidade $^{329-330}$, à inalienabilidade do nome empresarial ${ }^{331}$, aos limites do uso

${ }^{325}$ Tal discrímen normativo foi explicitado em pelo lapidar acórdão da lavra de Cezar Peluso, então Desembargador, na AC nº 78.942-1, 2a Câm. de Direito Privado, do TJSP, j. 02/12/1986

${ }^{326}$ Lei n' 10.406/2002, Parte Especial, Liv. II "Do Direito de Empresa", Tit. IV, Cap. II

${ }^{327}$ Cf. art. 1.163. O nome de empresário deve distinguir-se de qualquer outro já inscrito no mesmo registro. Parágrafo único. Se o empresário tiver nome idêntico ao de outros já inscritos, deverá acrescentar designação que o distinga

${ }^{328}$ Sobre o princípio da novidade, IN no 104/2007, do DNRC, assim redigido: "art. $6^{\text {o }}$. Observado o princípio da novidade, não poderão coexistir, na mesma unidade federativa, dois nomes empresariais idênticos ou semelhantes. $\S 1^{\circ}$ Se a firma ou denominação for idêntica ou semelhante a de outra empresa já registrada, deverá ser modificada ou acrescida de designação que a distinga. $§ 2^{\circ}$ Será admitido o uso da expressão de fantasia incomum, desde que expressamente autorizada pelos sócios da sociedade anteriormente registrada" ${ }^{329}$ Art. 1.165. O nome de sócio que vier a falecer, for excluído ou se retirar, não pode ser conservado na firma social

${ }^{330}$ V., igualmente, sobre o princípio da veracidade, a IN no 104/2007: “art. $5^{\circ}$ Observado o princípio da veracidade: I - o empresário só poderá adotar como firma o seu próprio nome, aditando, se quiser ou quando já existir nome empresarial idêntico, designação mais precisa de sua pessoa ou de sua atividade; II - a firma: a) da sociedade em nome coletivo, se não individualizar todos os sócios, deverá conter o nome de pelo menos um deles, acrescido do aditivo "e companhia", por extenso ou abreviado; b) da sociedade em comandita simples deverá conter o nome de pelo menos um dos sócios comanditados, com o aditivo "e companhia", por extenso ou abreviado; c) da sociedade em comandita por ações só poderá conter o nome de um ou mais sócios diretores ou gerentes, com o aditivo "e companhia", por extenso ou abreviado, acrescida da expressão "comandita por ações", por extenso ou abreviada; d) da sociedade limitada, se não individualizar todos os sócios, deverá conter o nome de pelo menos um deles, acrescido do aditivo "e companhia" e da palavra "limitada", por extenso ou abreviados;

III - a denominação é formada com palavras de uso comum ou vulgar na língua nacional ou estrangeira e ou com expressões de fantasia, com a indicação do objeto da sociedade, sendo que: a) na sociedade limitada, deverá ser seguida da palavra "limitada", por extenso ou abreviada; b) na sociedade anônima, deverá ser acompanhada da expressão "companhia" ou "sociedade anônima", por extenso ou abreviada, vedada a utilização da primeira ao final; c) na sociedade em comandita por ações, deverá ser seguida da expressão "em comandita por ações”, por extenso ou abreviada; d) para as sociedades enquadradas como microempresa ou empresa de pequeno porte, inclusive quando o enquadramento se der juntamente com a constituição, é facultativa a inclusão do objeto da sociedade; e) ocorrendo o desenquadramento da sociedade da condição de microempresa ou empresa de pequeno porte, é obrigatória a inclusão do objeto da sociedade empresária no nome empresarial, mediante arquivamento da correspondente alteração contratual. $\S 1^{\circ} \mathrm{Na}$ firma, observar-se-á, ainda: a) o nome do empresário deverá figurar de forma completa, podendo ser abreviados os prenomes; b) os nomes dos sócios poderão figurar de 
exclusivo $^{332}$, à prescrição para ação anulatória de registro ${ }^{333}$ e, por derradeiro, quanto à extinção da proteção ao nome ${ }^{334}$.

Por sua vez, a Lei de Registro Público de Empresas Mercantis e Atividades Afins dispõe especificamente sobre o nome empresarial nos artigos 33 a 35. Seu art. 33 reza que "a proteção ao nome empresarial decorre automaticamente do arquivamento dos atos constitutivos de firma individual e de sociedades, ou de suas alterações”. Salienta-se que os parágrafos $1^{\circ}$ e $2^{\circ}$, do referido art. 33, foram vetados pelo então Presidente, Itamar Franco. O parágrafo $1^{\circ}$ dizia que "a proteção abrange todo o território nacional”, enquanto o $2^{\circ}$ que "a extensão da proteção à jurisdição das demais Juntas Comerciais será feita através de comunicação expedida peja Junta originária de ofício”.

As razões do veto ${ }^{335}$ estavam assim fundamentadas: "realmente, a proteção ao nome empresarial está assegurada no artigo $5^{\circ}$, inciso XXIX, da Constituição Federal, princípio este reiterado no caput do art. 33 do examinado projeto de lei. Os limites dessa proteção, contudo, devem ser mantidos na área de jurisdição de cada Junta Comercial, conforme está hoje regulado, podendo a proteção ser estendida à jurisdição das demais Juntas a requerimento do interessado, mas nunca ex officio. De fato, a implantação de um novo procedimento não representaria nenhum avanço, principalmente se considerarmos que a grande maioria de empresas registradas é de firmas individuais (cerca de $50 \%$ do movimento das Juntas Comerciais) e de sociedades limitadas familiares (em torno de $49 \%$ ), cujo interesse, no que diz respeito à proteção ao nome empresarial, é circunscrito aos limites da própria Cidade, ou, no máximo, aos do Estado, restando apenas um número insignificante de grandes empresas cujo interesse potencial se amplia e as quais já são atendidas, mediante requerimentos, para extensão daquela proteção a outros Estados. Por outro lado, o que se afigura grave, é que a proteção ampliada ao âmbito nacional,

forma completa ou abreviada, admitida a supressão de prenomes; c) o aditivo "e companhia" ou "\& Cia." poderá ser substituído por expressão equivalente, tal como “e filhos" ou “e irmãos", dentre outras. § $2^{\circ} \mathrm{O}$ nome empresarial não poderá conter palavras ou expressões que denotem atividade não prevista no objeto da sociedade.

${ }^{331} \mathrm{CC}$, art. 1.164. O nome empresarial não pode ser objeto de alienação. Parágrafo único. O adquirente de estabelecimento, por ato entre vivos, pode, se o contrato o permitir, usar o nome do alienante, precedido do seu próprio, com a qualificação de sucessor

${ }^{332} \mathrm{CC}$, art. 1.166. A inscrição do empresário, ou dos atos constitutivos das pessoas jurídicas, ou as respectivas averbações, no registro próprio, asseguram o uso exclusivo do nome nos limites do respectivo Estado. Parágrafo único. O uso previsto neste artigo estender-se-á a todo o território nacional, se registrado na forma da lei especial.

${ }^{333} \mathrm{CC}$, art. 1.167. Cabe ao prejudicado, a qualquer tempo, ação para anular a inscrição do nome empresarial feita com violação da lei ou do contrato

${ }^{334} \mathrm{CC}$, art. 1.168. A inscrição do nome empresarial será cancelada, a requerimento de qualquer interessado, quando cessar o exercício da atividade para que foi adotado, ou quando se ultimar a liquidação da sociedade que o inscreveu 
generalizadamente, criaria uma enorme dificuldade na instituição de nomes diferentes, uma vez que é da ordem de $550 \mathrm{mil}$, em média, o número de novas empresas registradas por ano no Brasil. Para que se tenha uma idéia do caos que se estabeleceria, basta citar o exemplo das firmas individuais, cujo nome comercial é formado pelo nome civil do comerciante, abreviado ou por extenso, com a adição, se desejada ou necessária, de expressão diferenciadora. Com a proteção de âmbito estadual hoje existente, já é grande o número de colidências, fato que seria multiplicado algumas vezes se ela fosse ao Brasil inteiro estendida, automática e generalizadamente. Os parágrafos citados contrariam o interesse público".

Com o veto aos $\S \S 1^{\circ}$ e $2^{\circ}$ do art. 33, travou-se na doutrina e jurisprudência intensa discussão quanto ao âmbito de proteção do nome empresarial, como veremos mais adiante, não obstante o Decreto $\mathrm{n}^{\circ} 1.800$, de 30 de janeiro de 1996, que regulamentou da lei em comento, trazer em seu art. 61 que "a proteção ao nome empresarial, a cargo das Juntas Comerciais, decorre, automaticamente, da declaração de firma mercantil individual, do ato constitutivo da sociedade mercantil ou de alterações desses atos que impliquem mudança de nome".

Vale menção, ainda, o art. 34 da Lei de Registros Públicos de Empresas Mercantis, segundo o qual o nome empresarial obedecerá aos princípios da veracidade e da novidade. Quanto à veracidade, em se tratando de firma deverá consistir necessariamente no nome dos sócios não podendo, ainda, indicar objeto não previsto em seu contrato social. Por outro lado, o nome empresarial deverá ser distinto dos demais ${ }^{336}$.

Não é despiciendo citar a Lei $\mathrm{n}^{\circ} 11.598$, de 3 de dezembro de 2007, que criou a Rede Nacional para a Simplificação do Registro e da Legalização de Empresas e Negócios - REDESIM, com o objetivo de simplificar e integrar o processo de registro e legalização de empresários e pessoas jurídicas no âmbito da União, dos Estados, do Distrito Federal e dos Municípios. De acordo com esta Lei, os órgãos e entidades que componham a tal rede, no âmbito de suas competências, deverão manter a disposição dos usuários, de forma presencial e pela rede mundial de computadores, informações, orientações e instrumentos que permitam pesquisas prévias às etapas de registro ou inscrição, alteração e baixa de empresários e pessoas jurídicas, de modo a prover ao usuário certeza quanto à

\footnotetext{
${ }^{335}$ Publicadas no DOU de 21/11/1994, p. 17514

${ }^{336}$ Diz, ainda, o art. 35. Não podem ser arquivados:

III - os atos constitutivos de empresas mercantis que, além das cláusulas exigidas em lei, não designarem o respectivo capital, bem como a declaração precisa de seu objeto, cuja indicação no nome empresarial é facultativa;
} 
documentação exigível e quanto à viabilidade do registro ou inscrição. Notadamente quanto à pesquisa prévia, dispõe o $\S 3^{\circ}$ do art. $4^{\circ}$ que "quando o nome empresarial objeto da pesquisa prévia de que tratam o caput e o inciso III do $\S 1^{0}$ deste artigo for passível de registro pelo órgão público competente, será por este reservado em nome do empresário ou sócio indicado na consulta, pelo prazo de 48 (quarenta e oito) horas, contadas da manifestação oficial favorável”.

No que concerne à função econômico-concorrencial (ou objetiva) do nome comercial, nosso ordenamento jurídico a tutela, atualmente, através da Convenção da União de Paris, a Constituição Federal de 1988, o Código de Defesa do Consumidor e a Lei da Propriedade Industrial. Nesta função, o nome comercial entra no domínio da propriedade industrial, sujeitando-se às regras e princípios a ela inerentes. Logo, este conjunto de normas visa, sob o âmbito concorrencial, proteger o nome comercial usado para distinguir seu titular de seus concorrentes no âmbito das atividades econômicas, galgando relevante valor econômico.

No dizer de GAMA CERQUEIRA, "nessa função, o nome comercial já não consiste na simples designação do comerciante ou industrial; ao contrário, destaca-se dêle, torna-se objeto autônomo, um bem patrimonial" ${ }^{337}$. A função objetiva, continua o autor, "que caracteriza, individualiza e distingue a atividade do comerciante ou industrial, pessoa física ou jurídica, no campo da competência comercial" ${ }^{338}$.

Pois bem, a proteção ao nome comercial, neste desiderato, é tutelada pelo art. $5^{\circ}$, inc. XXIX, da Constituição Federal de 1988, segundo o qual “a lei assegurará aos autores de inventos industriais privilégio temporário para sua utilização, bem como proteção às criações industriais, à propriedade das marcas, aos nomes de empresas e a outros signos distintivos, tendo em vista o interesse social e o desenvolvimento tecnológico e econômico do País". Da exegese do citado inc. XXIX, do art. $5^{\circ}$, verifica-se que a proteção constitucional tutela o nome comercial em sua função econômico-concorrencial, denotando ser este um sinal distintivo ${ }^{339}$, com repercussão econômica.

$\mathrm{V}$ - os atos de empresas mercantis com nome idêntico ou semelhante a outro já existente

${ }^{337}$ Op. cit., vol. I, p. 487

${ }_{339}^{338}$ Op. cit., vol. I, p. 471

${ }^{339}$ Pois visa proteger, além das marcas e do nome empresarial, os "outros sinais distintivos", com a finalidade, daí a cláusula finalística "tendo em vista o interesse social e o desenvolvimento tecnológico e econômico do País", a exemplo da Constituição Estadunidense (art. I, section 8 of the United States Constitution: This empowers the Congress to legislate: "To promote the Progress of Science and useful Arts, by securing for limited Times to Authors and Inventors the exclusive Right to their respective Writings and Discoveries") 
De outra banda, a CUP, no já aludido art. $8^{\circ}$, garante proteção ao nome comercial, em todos os países da União sem obrigações de depósito ou de registro, quer faça ou não parte de uma marca de fábrica ou de comércio ${ }^{340}$.

É inconteste a aplicação da CUP, não só pela ratificação do Decreto 1.263/94, mas também pela norma expressa no art. $4^{\circ}$, da LPI: “as disposições dos tratados em vigor no Brasil são aplicáveis, em igualdade de condições, às pessoas físicas e jurídicas nacionais ou domiciliadas no País" 341.

Do até aqui exposto, pode-se dizer que "a proteção jurídica do nome comercial, em suas diversas modalidades, não depende de registro ou do cumprimento de qualquer formalidade, segundo o princípio universalmente aceito e consagrado, tanto em nossas leis e pelos Tribunais do país como na doutrina estrangeira e nas convenções internacionais" 342 .

E não era por outra razão que o STJ reconhecera, em diversos julgados, a desnecessidade de registro para a proteção do nome comercial ${ }^{343}$. Conclui-se, portanto, que o direito ao uso exclusivo do nome comercial independe de registro específico, surgindo com a constituição da sociedade, através do registro de seus atos constitutivos no respectivo registro ${ }^{344}$.

Soma-se, ainda, a LPI que, embora não trate especificamente do nome comercial, traz importantes dispositivos que acabam por resguardá-lo, no campo concorrencial. Nesse

\footnotetext{
${ }^{340}$ Redação dada pela Revisão de Estocolmo, cf. Decreto 1.263/1994

341 TINOCO SOARES informa que há corrente entendendo que "não mais se pode invocar a proteção conferida ao nome empresarial pelo art. 8 da CUP, por sua derrogação tácita (ou implícita) pelo art. 1.166 do Código Civil de 2002" (Nome comercial versus marca, cit., p. 34). A nosso ver, tal entendimento é equivocado, visto que as normas previstas no CC e na CUP tem escopo e finalidade distintos, protegendo, aquele o nome empresarial e esta o nome comercial, tendo em vista a diferenciação que explicitamos no Cap. II, supra. 342 GAMA CERQUEIRA, João da. Op. cit., vol. II, p. 194

${ }^{343}$ Recurso especial. Nome inapropriável. Expressão de uso comum. Precedentes.

1. A proteção a uso do nome dispensa, até mesmo, o registro, diante da necessidade de preservar a identidade da empresa nas suas relações com a clientela.

2. Mesmo que a expressão seja de uso comum não é possível, se anteriormente identifica determinada empresa, usá-la em outra, sob o argumento de ser inapropriável. 3. Recurso conhecido e provido. (STJ, $3^{\mathrm{a}}$ T., REsp 65.002/SP, Rel. Min. Carlos Alberto Menezes Direito, DJ 02/09/2002 p. 182; nosso grifo); Nome comercial. Marca. Exclusividade. Prescrição. (...) 2. O nome comercial deve ser protegido, nos termos da Convenção de Paris, vigente no Brasil, até mesmo na ausência de qualquer registro. (...) 4. Recurso conhecido e provido, em parte. (STJ, $3^{\mathrm{a}}$ T., REsp 40.021/SP, Rel. Min. Carlos Alberto Menezes Direito, DJ 26/08/2002 p. 211); Nome comercial. Marca. Convenção de Paris. Representação processual: regularização. Sustentação oral: Repetição. Competência. Precedentes da Corte. 1. Nome comercial e marca não se confundem, sendo a proteção do primeiro, na linha de precedentes da Corte, oferecida pelo art. $8^{\circ} \mathrm{da}$ Convenção de Paris, independentemente de qualquer registro. (...) 6. Recurso especial não conhecido. (STJ,

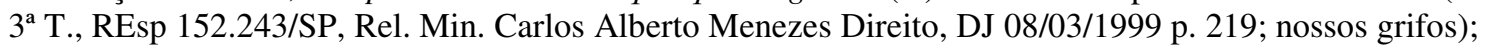
Nome comercial. Proteção decorrente do disposto no artigo $8^{\circ}$ da Convenção da União de Paris. Desnecessidade de que haja sido feito o registro no Brasil... (STJ, $3^{\mathrm{a}}$ T., REsp no 36.898-SP, Rel. Min. Eduardo Ribeiro, DJ de 28/03/94).
} 
sentido, o art. 124, inc. V veda o registro de marcas que constituam reprodução ou imitação de elemento característico ou diferenciador de título de estabelecimento ou nome de empresa de terceiros, suscetível de causar confusão ou associação com estes sinais distintivos.

Prevê a LPI, ainda, que é crime reproduzir ou imitar, de modo que possa induzir em erro ou confusão, armas, brasões ou distintivos oficiais nacionais, estrangeiros ou internacionais, sem a necessária autorização, no todo ou em parte, em marca, título de estabelecimento, nome comercial, insígnia ou sinal de propaganda, ou usar essas reproduções ou imitações com fins econômicos ${ }^{345}$. E, especificamente, como crime de concorrência desleal o uso, indevido, de nome comercial, título de estabelecimento ou insígnia alheios ou vende, expõe ou oferece à venda ou tem em estoque produto com essas referências ${ }^{346}$.

Ademais, o CDC traz, em seu art. $4^{\circ}$, inc. VI, como princípio da Política Nacional das Relações de Consumo, a coibição e repressão eficientes de todos os abusos praticados no mercado de consumo, inclusive a concorrência desleal e utilização indevida de inventos e criações industriais das marcas e nomes comerciais e signos distintivos, que possam causar prejuízos aos consumidores.

\section{O nascimento da proteção}

Para que se obtenha o direito de uso exclusivo do nome de empresa, não é suficiente sua mera criação pelo empresário. Nas palavras de DI FRANCO: “[o]nde resta ferma l'enunciata regola che il diritto all'uso esclusivo del nome commerciale à acquistato in modo originario dal primo utente indipendentemente da ogni formalità di registrazione e deposito" 347 . O direito decorre (nos termos do art. 1.166, do CC) da anterioridade de inscrição do empresário, ou dos atos constitutivos das pessoas jurídicas, ou das respectivas averbações, no registro correspondente ${ }^{348}$.

\footnotetext{
${ }^{344}$ Como vimos, a proteção do nome empresarial pelo arquivamento dos atos constitutivos é tradição centenária em nosso direito, v. Decreto n ${ }^{\circ} 916$, de 24 de outubro de 1890.

${ }^{345}$ Cf. art. 191, da LPI

${ }^{346} \mathrm{Cf}$. art. $195, \mathrm{~V}$, da LPI

${ }^{347}$ Di FRANCO, Luigi. Trattato della Proprietà Industriale, cit., p. 382

${ }^{348}$ A jurisprudência já caminhava neste sentido, especialmente considerando o leading case "RESET" (STJ, $4^{\mathrm{a}}$ T., REsp 6.169-AM, rel. Min. Athos Carneiro, j. 25/05/1991, TSTJ Lex no 30, p. 162), que modificou o entendimento até então prevalente que assegurava proteção maior à marca registrada do INPI, do que ao nome, ainda que anterior [nesse sentido, v. caso "COBRASIL” (DJU, Seção I, de 13/12/1991, p. 18.355) e o caso "RAINHA" (STF, 2 a T., RE 111.971/SP, Rel. Min. Carlos Madeira, j. em 31/03/1987, DJ 24/04/1987,
} 
Note-se, portanto, que não há necessidade de qualquer registro do nome de empresa, como lamentavelmente já ocorreu no Brasil ${ }^{349}$.

Nesse sentido, o art. 8 da CUP faz referência ao uso, prescrevendo que a proteção ao nome comercial dá-se independentemente de qualquer registro. ASCARELLI salienta que em havendo conflito entre titulares de nomes comerciais idênticos deve-se levar em conta a prioridade do uso, de modo que o registro do nome do órgão competente apenas cumprirá uma função de publicidade ${ }^{350}$.

É pacífico na doutrina o entendimento de que "a proteção jurídica do nome comercial, em suas diversas modalidades, não depende de registro ou do cumprimento de qualquer formalidade, segundo o princípio universalmente aceito e consagrado, tanto em nossas leis e pelos Tribunais do país como na doutrina estrangeira e nas convenções internacionais" 351 .

Desta forma, o direito ao uso exclusivo do nome de empresa independe de registro, surgindo com a constituição da sociedade, através do registro de seus atos constitutivos no respectivo registro, como já reconheceu o STJ, em diversos julgados ${ }^{352}$.

Nesse sentido, a Lei de Registros Públicos de Empresas Mercantis dispõe especificamente em seu art. 33 que "a proteção ao nome empresarial decorre automaticamente do arquivamento dos atos constitutivos de firma individual e de sociedades, ou de suas alterações".

pp. 07196)]. Aplicou-se, assim, o vetusto princípio prior in tempore, melior in jure, dando ao nome proteção extensiva a todo o território nacional, já que litigavam empresas constituídas em Estados diferentes.

${ }^{349}$ Como vimos linhas acima, chocando-se com o art. $8^{\circ}$ da CUP, o Decreto 916/1.890 criou o registro das firmas e razões comercias nas Juntas Comerciais. Posteriormente, o Decreto $n^{\circ} 24.507 / 1934$, criou o registro federal do nome comercial e do título de estabelecimento, o qual somente veio a ser extinto em 1.969, com o Decreto-Lei no 1.005 (art. 166).

${ }^{350}$ Cf. ASCARELLI, Tullio. Op. cit, p. 371

${ }^{351}$ Gama CerQueIRA, João da. Tratado da propriedade industrial, cit., v. 1., p. 509.

${ }^{352}$ Recurso especial. Nome inapropriável. Expressão de uso comum. Precedentes.

1. A proteção a uso do nome dispensa, até mesmo, o registro, diante da necessidade de preservar a identidade da empresa nas suas relações com a clientela. 2. Mesmo que a expressão seja de uso comum não é possível, se anteriormente identifica determinada empresa, usá-la em outra, sob o argumento de ser inapropriável. 3. Recurso conhecido e provido. (STJ, $3^{\mathrm{a}}$ T., REsp 65.002/SP, Rel. Min. Carlos Alberto Menezes Direito, DJ 02.09.2002 p. 182; nosso grifo); Nome comercial. Marca. Exclusividade. Prescrição. (...) 2. O nome comercial deve ser protegido, nos termos da Convenção de Paris, vigente no Brasil, até mesmo na ausência de qualquer registro. (...) 4. Recurso conhecido e provido, em parte. (STJ, $3^{\mathrm{a}} \mathrm{T}$., REsp 40.021/SP, Rel. Min. Carlos Alberto Menezes Direito, DJ 26.08.2002 p. 211); Nome comercial. Marca. Convenção de Paris. Representação processual: regularização. Sustentação oral: Repetição. Competência. Precedentes da Corte. 1. Nome comercial e marca não se confundem, sendo a proteção do primeiro, na linha de precedentes da Corte, oferecida pelo art. $8^{\circ}$ da Convenção de Paris, independentemente de qualquer registro. (...) 6. Recurso especial não conhecido. (STJ, $3^{\mathrm{a}}$ T., REsp 152.243/SP, Rel. Min. Carlos Alberto Menezes Direito, DJ 08.03.1999 p. 219; nossos grifos); Nome comercial. Proteção decorrente do disposto no artigo $8^{\circ}$ da Convenção da União de Paris. Desnecessidade de que haja sido feito o registro no Brasil... (STJ, $3^{\text {a }}$ T., REsp no 36.898-SP, Rel. Min. Eduardo Ribeiro, DJ de 28/03/94). 
O Código Civil trouxe disposição similar em seu art. 1.166, segundo o qual "a inscrição do empresário, ou dos atos constitutivos das pessoas jurídicas, ou as respectivas averbações, no registro próprio, asseguram o uso exclusivo do nome nos limites do respectivo Estado".

O arquivamento dos atos constitutivo no registro próprio estabelece presunção júris et de jure da existência do nome empresarial relativamente a terceiros (publicidade do registro); faz presumir que o nome é distinto de qualquer outro; atribui ao nome direito de preferência ficando absolutamente privado de inscrição qualquer outro que possa ocasionar erro ou confusão; confere a quem primeiro registrou o nome o direito exclusivo de usá-la ou empregá-la" 353 .

\section{4. $O$ conflito entre nomes empresariais}

No intuito de proteger o nome empresarial, a legislação veda o registro de nomes que reproduzam ou imitem nomes empresariais de terceiros, conforme dispõem expressamente os artigos 34 e 35 da Lei $n^{\circ} 8.934 / 94$, art. 1.163 do CC e art. $4^{\circ}$ da IN n $^{\circ}$ 104, do DNRC. Tal preceito deriva, pois, do princípio da novidade, que permeia toda legislação atinente ao nome empresarial.

Logo, em atenção ao princípio da novidade, não podem inscritos empresários individuais ou ser arquivados atos constitutivos ou alterações contratuais de empresas mercantis com nome empresaria (seja firma, seja denominação) idêntico ou semelhante a outro previamente existente. É dizer, o nome deve distinguir-se de qualquer outro já inscrito, independentemente do ramo de atividade, de forma a não causar confusão diante dos consumidores.

Assim, importante esclarecer os critérios de colidência entre as diversas modalidades de nome de empresa, isto é, vislumbrando que o conflito pode dar-se entre firmas, entre firmas e denominações ou entre denominações.

\subsection{Os critérios de colidência entre firmas e razões sociais}

Vimos que o empresário individual opera necessariamente sob firma constituída por seu nome, completo ou abreviado, aditando-lhe, se quiser, designação mais precisa da sua

${ }^{353}$ Cf. MendonçA, José Xavier Carvalho de. Op. cit., p. 172/173 
pessoa ou do gênero de atividade. Verificamos, também, que as sociedades em que os sócios respondem solidária e ilimitadamente pelas obrigações contraídas, devem adotar firma social, como as sociedades em nome coletivo, as sociedades em comandita simples e as sociedades em comandita por ações.

A firma deverá sempre ser constituída pelo nome civil do empresário ou de pelo menos um deles no caso de sociedade, não sendo permitidos nomes de terceiros, em atenção ao dever de veracidade.

Em relação às firmas, já que constitui direito do empresário exercer suas atividades com seu nome civil, a confrontação entre as firmas deve ser feita considerando os nomes como um todo. Nesse sentido, o art. $8^{\circ}$, inc. I, da IN no 104, do DNRC, segundo o qual entre firmas, consideram-se os nomes por inteiro, havendo identidade se homógrafos e semelhança se homófonos.

Em havendo colidência, entre firmas individuais devem-se agregar ao seu nome outros elementos (prenome, designação mais precisa de sua pessoa, ou gênero de atividade) que o distinga. Da mesma forma ocorre em se tratando de conflito onomástico entre firmas ou razões sociais, devendo ser acrescida designação que a distinga, conforme o parágrafo único, do art. 1.163, do CC.

É o que dizia AfFOnSo CELSO: "[n]o caso de homonymia, dissemol-o já a Lei limita-se a supprimil-a, para o fim de evitar prejuízos provenientes da identidade ou semelhança de nome ou firma, usados não no intuito da fraude, porém muito legitimamente por pertencerem ao negociante ou industrialista concurrente. O meio de que para isso ella se serve é deteminar, que o nome ou a firma daquelle que posteriormente abraçou o mesmo gênero de industria ou de commercio seja modificado de modo à bem distinguir-se do outro, removendo-se assim a possibilidade de enganos. (...) Salva a prioridade, há na especie perfeita igualdade de direito entre o reclamante e o concurrente contra quem se reclama, e a missão da Lei é concilial-os. É livre a cada qual usar o nome que têm, assim como adoptar a carreira que lhe aprouver. Portanto, si existe alguem que possua o mesmo nome, já estabelecido na especialidade, que outrem escolher, não se pode vedar a este que a explore na mesma cidade, no mesmo mercado, e sob a denominação que lhe é própria; apenas não lhe é permittido exercer esse direito por forma a lesar quem o possue idêntico e antecedeu-o na profissão" 354 .

${ }^{354}$ CELSO, Affonso. Op. cit., p. 200 


\subsection{Os critérios de colidência entre denominações sociais}

Já o tratamento dado às denominações sociais é diferente. A denominação social, ao contrário das firmas, pode ser constituída arbitrariamente, de modo que o grau de similaridade tolerado é menor. Evidentemente, se pode o empresário escolher livremente o nome de fantasia que comporá sua denominação social, esta deve ser necessariamente distinta em relação às demais ${ }^{355}$.

Inexcedível, nesse sentido, a lição de ASCARELLI: “[e]s decir, puede cuestionarse si la denominación social no debería diferenciarse de la de cualquier otra persona jurídica o colectividad y si, a su vez, no debería protegerse en todo el territorio nacional y, por tanto, más allá del ámbito de la actividad desarrollada y de su esfera territorial, contra la posibilidad de confusión con la denominación de otra persona jurídica o colectividad. De otro modo, en efecto, la tutela de la denominación no comprende el posible perjuicio que también puede ocasionar (por ejemplo, a efectos del crédito bancario) una denominación similar para actividades diversas; esta consecuencia, admisible en el nombre comercial e inevitable en el nombre civil, por la lícita existencia homónimos, está lejos de ser necesaria para la denominación, libremente elegida, de la persona jurídica o de la colectividad organizada" ${ }^{356}$.

No mesmo diapasão afina-se o entendimento de GAMA CERQUEIRA, segundo o qual: "sendo as denominações escolhidas livremente, podem diferenciar-se de modo mais sensível, o que justifica maior severidade na apreciação de sua semelhança com outras denominações existentes". E continua argumentando o autor que: “[ê] ste princípio tem aplicação, sobretudo, quando se trata de denominações caracterizadas por expressões inteiramente arbitrárias, caso em que a possibilidade de confusão deve ser apreciada tendose em vista, principalmente, essas expressões" ${ }^{357-358}$.

\footnotetext{
${ }^{355}$ No dizer de GHIRON: "[p]erò la legge esige che la denominazione o la designazione della società anonima si distingua chiaramente da quel di ogni altra società” (op. cit., p. 228)

${ }^{356}$ ASCARELLI, Tullio. Op. cit., p. 379/380

${ }^{357}$ GAMA CERQUEIRA, João da. Op. cit., p 501

${ }^{358}$ Newton SILVEIRA aduz que: “[o] reconhecimento do fato de uma sociedade ser conhecida por uma só palavra de fantasia (o chamado mot vedette), impedindo-se sua adoção na composição de outra denominação, implica no reconhecimento da existência do nome comercial objetivo" (in Licença de uso de marca..., cit., p. 57)
} 
Na mesma esteira manifestou-se NEWTON SILVEIRA: “o nome empresarial é direito exclusivo absoluto, não limitado ao ramo de atividade, de modo que, ao menos quanto às denominações, não podem coexistir no território nacional duas idênticas" ${ }^{359}$.

A semelhança pode ser gráfica, fonética ou intelectual ou ideológica, na qual o risco de confusão ou erro surge da associação de idéias por os sinais em confronto serem passíveis de suscitar a mesma imagem ou sugestão ${ }^{360}$.

O Decreto no 1800/1996, que regulamentou a Lei $n^{\circ}$ 8934/94, incumbiu o DNRC, através de instruções normativas, a disciplinar a composição do nome empresarial e estabelecer critérios para verificação da existência de identidade ou semelhança entre nomes empresariais ${ }^{361}$.

Desta forma, a IN n 104/2007 em seu art. 8º estabeleceu os critérios para análise de colidência entre as denominações, dispondo que (a) consideram-se os nomes por inteiro, quando compostos por expressões comuns, de fantasia, de uso generalizado ou vulgar, ocorrendo identidade se homógrafos e semelhança se homófonos; e (b) quando contiverem expressões de fantasia incomuns, serão elas analisadas isoladamente ${ }^{362}$, ocorrendo identidade se homógrafas e semelhança se homófonas.

Outrossim, para a análise de colidência deve-se levar em consideração que não são exclusivas, para fins de proteção, palavras ou expressões que denotem: (a) denominações genéricas de atividades; (b) gênero, espécie, natureza, lugar ou procedência; (c) termos técnicos, científicos, literários e artísticos do vernáculo nacional ou estrangeiro, assim como quaisquer outros de uso comum ou vulgar; (d) nomes civis ${ }^{363}$.

Ademais, ressalte-se que sociedades coligadas que operam em um mesmo ramo, p. ex., coligadas a um Banco, podem compartilhar a mesma expressão característica (mot vedette), desde que as denominações por inteiro possuam elementos para diferenciá-las, podendo, entretanto, qualquer uma delas opor-se à constituição de sociedades não coligadas com a utilização da mesma palavra característica ${ }^{364}$.

\footnotetext{
${ }^{359}$ SILVEIRA, Newton. A Propriedade Intelectual: propriedade industrial, dirieto de autor, software, cultivares, $3^{\text {a }}$ edição rev. e ampl., São Paulo: Manole, 2005, p. 20

${ }^{360}$ Cf. Olavo, Carlos. Op. cit., p. 206

${ }^{361} \mathrm{Cf}$. Art. 62, § $3^{\circ}$ do Decreto n ${ }^{\circ} 1800 / 96$

${ }^{362}$ Segundo ASCARELLI, “[a]sí pues, deberá tenerse en cuenta el elemento característico de la denominación, habida en cuenta de la grafía y del aspecto fonético, para juzgar acerca de la posibilidad de confusión y, por tanto, de la ilegitimidad de una denominación (independientemente de un daño actual o posible). La denominación viene tutelada, también, frente al nombre comercial individual y viceversa" (op. cit., p. 384).

${ }^{363}$ Cf. art. $9^{\circ}$, da IN n ${ }^{\circ}$ 104/2007, do DNRC

${ }^{364}$ Cf. SILVEIRA, Newton. Nome comercial objeto e subjetivo, in RDM no 45, jan./mar. 1982.
} 


\subsection{Os critérios de colidência entre denominações e firmas}

As sociedades limitadas e sociedades anônimas, como vimos no Cap. III supra, podem adotar firma ou denominação sendo possível usar o nome civil de seus sócios para compor sua denominação, caso em que será tratado como elemento de fantasia.

Optando por adotar o nome civil dos sócios, ainda que na forma de denominação, a sociedade não poderá insurgir-se contra firmas que compostas pelo mesmo nome, ainda que no mesmo ramo de atividade.

A única exceção é no caso de flagrante concorrência desleal, caso em que, provada a má-fé na adoção do nome, "poderá o magistrado, em casos extremos, uma vez que só a verdadeira impossibilidade de se evitar a concorrência desleal admitiria restrições ao direito de cada pessoa empregar o seu nome civil para designar-se e designar a sua atividade econômica, como já foi dito em relação às firmas, proibir a adoção do nome civil na composição do nome comercial posterior" 365 .

Nesse sentido, havia indigitado o STF: “[p]atronímico usado em nome comercial antigo, que veio a ser utilizado em nova firma, fundada por sócio dissidente. Não afasta a proteção ao nome comercial, o fato de o sócio dissidente ter o mesmo apelido de família, pois a proteção aquele decorre do ordenamento jurídico da concorrência. $O$ nome comercial como um todo não minimiza a concorrência desleal, quando nele a nuclear, identificadora da firma nova, e semelhante à de nome já registrado, dando margem à confusão. A observância da regra da lei de sociedades por quotas de responsabilidade limitada, no tocante ao nome comercial da nova firma, não pode resultar em vulneração ao direito concorrencial" 366 .

Assim, a circunstância do uso de patronímico não altera o princípio maior da proteção ao nome comercial, subordinado ao princípio da anterioridade, nos termos do art. $8^{\circ}$ da LPI, na forma da revisão de Haia de $1925^{367}$.

\footnotetext{
${ }^{365}$ GRAU-KunTZ, Karin. Op. cit., p. 76

${ }^{366}$ STF, RE 109478, Rel. Min. Carlos Madeira, 2a T., j. em 30.09.1986, DJ 10-04-1987 pp-06421 (caso "Eberle")

${ }^{367}$ Cf. REsp 406.763/SP, Rel. Min. Carlos Alberto Menezes Direito, $3^{\text {a }}$ T., j. em 19/09/2002, DJ 11/11/2002

p. 212 (Caso "Maeda")
} 


\subsection{A questão das siglas}

A IN n 104/2007, do DNRC, considera que não são suscetíveis de exclusividade letras ou conjunto de letras, desde que não configurem siglas (art. $9^{\circ}$ ). Este dispositivo merece atenção, pois limita indevidamente a proteção a nomes empresariais legítimos.

Sigla ou acrógrafo é a letra inicial ou conjunto de letras iniciais de um nome próprio empregada(s) como monograma ${ }^{368}$, mais especificamente é a redução de um nome complexo às suas letras iniciais, formando ou não palavras (v.g. USP para Universidade de São Paulo ou O.M.P.I para Organização Mundial da Propriedade Intelectual); sílabas iniciais, formando quase-palavras (Benelux para Bélgica, Países Baixos e Luxemburgo) e partes iniciais formando quase-palavras (Petrobras para Petróleo Brasileiro S.A ou Bradesco para Banco Brasileiro de Descontos S.A).

Temos, portanto, que a diferença entre sigla e ou conjunto de letras é, apenas, o fato de a sigla ser formada por letras, sílabas ou partes iniciais das demais palavras que compõem o nome empresarial, ao passo que o conjunto de letras é aleatório.

A nosso ver, um conjunto de letras pode não só compor nomes empresariais, mas também marcas, podendo revestir-se de distintividade, identificando a própria sociedade empresária, assim como seus produtos e/ou serviços. Ora, uma vez adotado um conjunto de letras para identificação da sociedade empresária, é evidente que o uso por outrem de conjunto idêntico ou similar causará confusão no mercado, comprometendo a identificação daquele que primeiro o adotou.

Com ensinou GHIRON, “[d]'altro canto, a nessuno è lecito usare, per la propria azienda, nome ou la ditta, od altro segno distintivo, in guisa che si possano confondere col nome o con la ditta che altri usa già lecitamente, ne'lla guisa da menomare, con la capacità distintiva del nome o della ditta altrui, quell'attitudine al richiamo ed all'assorbimento della clientela, che la legge intende proteggere” ${ }^{369}$.

Nesse sentir, a jurisprudência reconhece o uso exclusivo dos conjuntos de letras usados como sinais identificadores no mercado, preservando a identidade, a reputação, conceito e crédito de seu titular ${ }^{370}$, salvo se o conjunto de letras for comum ou vulgar ${ }^{371}$.

\footnotetext{
${ }^{368}$ Cf. Dicionário Houaiss da Língua Portuguesa. Rio de Janeiro: Objetiva, 2001, $1^{\text {a }}$ ed., p. 2.568.

${ }^{369}$ GHIRON, Mario. Op., cit., p. 229

${ }^{370}$ Nesse sentido: TJSP, $7^{\mathrm{a}}$ Câm. de Direito Privado, AC. 83.919-4/6, rel. Des. Oswaldo Breviglieri, j. 11/08/1999 (Caso "RS”); TJSP, 4 Câm. de Direito Privado, AC. 55.308-4/8, rel. Des. Fonseca Tavares, j. 01/10/1998 (Caso "KRS")

${ }^{371}$ Vide: TJSP, 8 a Câm. de Direito Privado, AC. 338.085-4/1-00, rel. Des.Salles Rossi, j. 28/06/2007 (Caso "JR");
} 


\section{O âmbito e a extensão da proteção ao nome empresarial}

Vimos no Cap. II que a questão da fixação da natureza do nome empresarial é de grande importância para delinear a extensão e o âmbito de proteção do nome empresarial, pois se considerarmos o nome empresarial como direito de personalidade do empresário, sua proteção será absoluta, independentemente de relação de concorrência, a qual somente atuará como fator agravante.

Este é o entendimento de GAMA CERQueIRA, para o qual: "[n]ão importa que diversifique o gênero de comércio ou indústria explorado, porque a proteção do nome comercial não pressupõe necessariamente o elemento concorrência, circunstância que, entretanto, influi para agravar a possibilidade de confusão e as suas consequências" ${ }^{372-373 .}$.

Contudo, considerando o nome empresarial como direito pessoal do empresário, a relação de concorrência é inerente, para que se estabeleça a relação obrigacional. Diferente também será o tratamento se o considerarmos propriedade do empresário.

Externamos nossa opinião no sentido de que o direito ao nome empresarial decorre da personalidade do empresário ou sociedade empresária, e nasce do arquivamento dos atos constitutivos no respectivo registro ${ }^{374}$. Isso, porém, não quer dizer que ambas as funções desenvolvidas pelo nome empresarial (função identificadora e função econômicoconcorrencial) devem ter o mesmo tratamento em razão de sua natureza. A proteção jurídica reivindicada em cada caso concreto terá como base uma ou ambas as funções, cada qual com tratamento diferenciado. Dizia PONTES DE MIRANDA: “[o] nome comercial tem, portanto, duas proteções, uma a êle mesmo, como nome de pessoa, que é, e outra, a interesses patrimoniais que derivam de tê-lo ou de usá-lo. Por isso mesmo, quem tem

\footnotetext{
${ }^{372}$ In Tratado da Propriedade Industrial, cit., vol. II, t. II, p. 321

${ }^{373}$ PONTES DE MIRANDA, que entendia o direito ao nome comercial como direito personalíssimo, afirmava que "[a] firma social e a denominação da pessoa jurídica têm a mesma proteção que a firma individual; e tôdas, a mesma proteção do nome civil, seja da pessoa jurídica, seja da pessoa física. Por isso mesmo, $a$ ) podem ser protegidas ainda se se trata de comércios, indústrias, ou atividades agrícolas, diferentes. $b$ ) proteção limitada ao comércio, indústria e agricultura similares já diz respeito à proteção da marca" (op. cit., p. 241)

${ }^{374}$ Como também já se manifestou o STJ. Confira-se: NOME COMERCIAL. DIREITO A EXCLUSIVIDADE. REGISTRO NA JUNTA COMERCIAL. PREVALENCIA. O direito ao uso exclusivo do nome comercial em todo território nacional não esta sujeito a registro no INPI, e surge tão-só com a constituição jurídica da sociedade, através do registro de seus atos constitutivos no registro do comercio, devendo prevalecer o registro do nome comercial feito com anterioridade, no caso de firmas com a mesma denominação e objeto social semelhante, que possibilite confusão. Lei 4726/65, art. 38, IX; DLei 1005/69, art. 166; Lei 5772/71, arts. 65, item 5, e 119; Convenção de Paris, de 1888, adotada no Brasil pelo decreto 75.572/75. Recurso especial conhecido e provido. (STJ, 4 ${ }^{\mathrm{a}}$ T., REsp 6.169/AM, Rel. Min. Athos Carneiro, j.
} 
direito ao nome, por ser o seu, não fica privado de usá-lo, devido à homonímia, mas o uso em atividade comercial, industrial ou agrícola, como nome comercial, pode caracterizar crime" 375 .

O primeiro reflexo deste entendimento incide sobre o âmbito de proteção do nome empresarial. Como vimos, o Decreto 916/1.890 criou o registro das firmas e razões sociais nas Juntas Comerciais e, posteriormente, o Decreto $n^{\circ} 24.507 / 1934$, criou o registro federal do nome comercial e do título de estabelecimento, o qual somente veio a ser extinto em 1.969, com o Decreto-Lei $n^{o} 1.005$. Este último decreto, além de abolir o registro dos nomes comerciais, trouxe disposição específica quanto à sua proteção, estabelecendo, em seu art. 166, que: “[a] proteção ao nome comercial ou de emprêsa, em todo o território nacional, é adquirida através do arquivamento ou registro dos atos constitutivos da firma ou sociedade no Registro do Comércio ou no Registro Civil das pessoas jurídicas, conforme o caso".

Este artigo, lamentavelmente, não foi reproduzido no posterior Código da Propriedade Industrial de 1.971, gerando incertezas principalmente quanto ao âmbito de proteção do nome empresarial.

A jurisprudência pátria passou, então, a oscilar quanto ao limite territorial da proteção ao nome empresarial, ora conferindo-lhe proteção ora internacional ${ }^{376}$, ora nacional $^{377}$, ora estadual ${ }^{378}$, ora municipal ${ }^{379}$.

em 25.06.1991, DJ 12/08/1991 p. 10557); v. também 3 3a T., REsp 67.173/PE, Rel. Min. Costa Leite, j. em 09.04.1996, DJ 01/07/1996, p. 24048.

${ }^{375}$ Pontes De MIRANDA. Tratado de Direito Privado, Parte Especial, Rio de Janeiro: Borsoi, 1956, t. XVII, p. 254

${ }^{376}$ Caso LACOST (vide RDM 52/75-87); NOME COMERCIAL. DIREITO A EXCLUSIVIDADE. REGISTRO NA JUNTA COMERCIAL. PREVALENCIA. O direito ao uso exclusivo do nome comercial em todo território nacional não esta sujeito a registro no INPI, e surge tão-só com a constituição jurídica da sociedade, através do registro de seus atos constitutivos no registro do comercio, devendo prevalecer o registro do nome comercial feito com anterioridade, no caso de firmas com a mesma denominação e objeto social semelhante, que possibilite confusão. Lei 4726/65, art. 38, IX; DLei 1005/69, art. 166; Lei 5772/71, arts. 65, item 5, e 119; Convenção de Paris, de 1888, adotada no Brasil pelo decreto 75.572/75. Recurso especial conhecido e provido. (STJ, $4^{a}$ T., REsp 6169/AM, Rel. Min. Athos Carneiro, j. em 25/06/1991, DJ 12.08.1991 p. 10557); MARCA. REGISTRO PROMOVIDO JUNTO AO INPI. PREVALÊNCIA SOBRE A UTILIZAÇÃO PROLONGADA, DECORRENTE DA ADOÇÃO DO NOME COMERCIAL. MARCA E NOME SUBMETIDOS A REGIMES JURÍDICOS DIVERSOS. - Marca e nome comercial não se confundem. "A primeira, cujo registro é feito junto ao INPI, destina-se a identificar produtos, mercadorias e serviços. O nome comercial, por seu turno, identifica a própria empresa, sendo bastante para legitimá-lo e protegê-lo, em âmbito nacional e internacional, o arquivamento dos atos constitutivos no Registro do Comércio" (REsp n ${ }^{\circ}$ 9.142-SP). - Pelo sistema adotado pela legislação brasileira, afastou-se o prevalecimento do regime da "ocupação" ou da "utilização prolongada" como meio aquisitivo de propriedade da marca. O registro no INPI é quem confere eficácia "erga omnes", atribuindo àquele que o promoveu a propriedade e o uso exclusivo da marca. Precedentes do STJ. Recurso especial conhecido e provido parcialmente. $\left(4^{\mathrm{a}} \mathrm{T}\right.$., REsp 52.106/SP, Rel. Min. Barros Monteiro, j. em 17/08/1999, DJ 29/11/1999 p. 164); PROPRIEDADE INDUSTRIAL. Nome comercial. "AUDI". Caução do art. 835 do CPC. - Não acarreta a nulidade do processo o depósito tardio da caução exigida pelo art. 835 do CPC, falta que não prejudicou o processo nem 
A divergência também se verificou na doutrina, pendendo, pois, de acordo com a concepção dos autores acerca da natureza do nome empresarial. Para NEWTON SILVEIRA “representa (o nome empresarial) também um direito exclusivo, como as marcas, mas esta proteção não é adstrita ao ramo de atividade, pois envolve a própria identificação do comerciante ou industrial em suas relações comerciais e de crédito, não se limitando ao aspecto concorrencial" ${ }^{380}$. Logo, para este autor, a proteção ao nome empresarial não poderia sofrer qualquer limitação territorial.

Neste mesmo sentido manifestou-se FRÓES: "quanto à extensão geográfica da proteção ao nome comercial, deve ser não local, como dispunham o art. $6^{\circ}$ do Decreto $n^{\circ}$ 916 e parágrafo único do art. 106 do Decreto-Lei ${ }^{\circ}$ 7.903/45, mas nacional, quando não internacional, por força do art. $8^{\circ}$ da Convenção de Paris, segundo o qual o nome comercial será protegido em todos os países signatários, independentemente de qualquer registro, faça ou não parte da marca de indústria ou comércio (Dec. $\left.N^{\circ} 75.572 / 75\right)$. Esse dispositivo convencional pode ser aplicado como lei interna por força do art. $4^{\circ}$ do CPI (Lei $\mathrm{n}^{\circ}$ 5.772/71), como anteriormente referido. Tal proteção emerge do simples arquivamento ou registro dos atos constitutivos da empresa no Registro do Comércio, i.e., a partir do

causou dano à parte adversa. - O nome Audi, de titularidade de empresa estrangeira, tem proteção no Brasil por força de tratados internacionais. Recurso não conhecido. (STJ, 4ª T., REsp 331.022/RJ, Rel. Min. Ruy Rosado de Aguiar, j. em 07/03/2002, DJ 06.05.2002 p. 296)

377 "Vê-se que a tutela é predisposta de forma ampla, alcançando, em âmbito nacional, todo nome comercial, seja firma ou denominação, que, inclua, ou não, elemento constitutivo de marca de indústria ou de comércio, e independendo, até, de qualquer registro, consoante expresso no art. $8^{\circ}$ da Convenção de Paris" (TJSP, $2^{\mathrm{a}}$ Câm. de Direito Privado, Ap. civ. 78.942-1, rel. Des. Cezar Peluso, j. 02.12.1986); PROPRIEDADE INDUSTRIAL MARCA - NÃO SE PODE IMPEDIR O USO DA MARCA, E A EXCLUSIVIDADE, A QUEM E TITULAR DE REGISTRO NO ORGÃO PROPRIO. Violação do disposto no artigo 59 do Código da Propriedade Industrial. Nome comercial - o registro na junta comercial produz eficácia em todo o território nacional. O ulterior registro por terceiro, como marca, de expressão de fantasia que nele figura não impede que continue a ser utilizado. (STJ, $3^{\mathrm{a}}$ T., REsp 11.767/SP, Rel. Min. Eduardo Ribeiro, j. em 29.06.1992, DJ 24/08/1992 p. 12997); "Não se há falar em extensão da proteção legal conferida às denominações de sociedades empresárias nacionais a todo o território pátrio, com fulcro na Convenção da União de Paris, porquanto, conforme interpretação sistemática, nos moldes da lei nacional, mesmo a tutela do nome comercial estrangeiro somente ocorre em âmbito nacional mediante registro complementar nas Juntas Comerciais de todos os Estados-membros" (4ª T., EDcl nos EDcl no AgRg no REsp 653.609/RJ, Rel. Min. Jorge Scartezzini, j. em 19/05/2005, DJ 27.06.2005 p. 408). Vide ainda o já citado caso "RESET” já citado (REsp 6.169-AM); caso “BAGUETTE” (REsp 9.142-SP), caso "BENETTON” (REsp 152.243-SP) e o caso

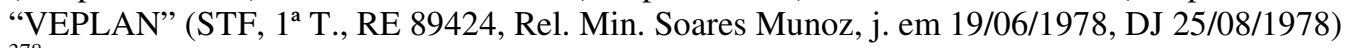

${ }^{378}$ Comercial. Propriedade industrial. Uso de marca. Produtos que guardam estreita afinidade mercadológica. Inexistência de diferenciação fonética (Unipoxi e Unipox). Registro perante o INPI possui eficácia em todo o território nacional e prevalece sobre o efetuado na Junta Comercial de âmbito tão-só na esfera estadual. Recurso improvido. (TJRJ, 4 ${ }^{\mathrm{a}}$ Câm. Cível, AC 1993.001.06650, Des. Alvaro Mayrink da Costa, j. 13/09/1994); Nome comercial. A existência de uma palavra comum em denominações diversas de sociedades constituídas em Estados diversos, não pode dar margem à concorrência desleal ou desvio de clientela (TJRJ, Ap. Civ. 40.426, j. 03/11/1986), citado por Gabriel F. LEONARDOS, op. cit., p. 28

${ }^{379}$ TJSP, AC. $n^{\circ}$ 30.143-1 de 02/08/1983 e STF, RE 80.877/RJ de 04/12/1979, ambos citados por Gabriel F. LEONARDOS, op. cit., p. 28

${ }^{380}$ SILVEIRA, Newton. A propriedade intelectual e a nova Lei da Propriedade Industrial, cit., p. 17. 
momento em que a empresa passa a ter existência legal. Se o nome comercial é tutelado, independentemente de qualquer registro, em todos os países da União de Paris, com muito maior razão deve sê-lo em todo o território brasileiro, pois, do contrário, as empresas nacionais ficariam em situação menos vantajosa que as empresas estrangeiras, no Brasil. De fato, estas teriam o direito de impedir que seus nomes comerciais fossem usurpados ou imitados, mas aquelas não teriam tal direito se a usurpação ou imitação partisse de outras empresas nacionais, localizadas em Estados diferentes na federação. Seria, assim, um contra-senso que o art. $8^{\circ}$ da LPI protegesse o nome comercial de estrangeiros, no Brasil, e não protegesse o de sociedades brasileiras, no mesmo país" 381.

Já Philomeno J. DA COSTA ${ }^{382}$ e TinOCO SOARES ${ }^{383}$ entendem que a proteção deve ser estadual, ou seja, limitada à circunscrição da Junta Comercial em que foram arquivados os atos da sociedade. Diz TINOCO SOARES que: “a 'proteção ao nome empresarial' em face da lei e de seu regulamento é 'limitada à unidade da federação', logo, não se poderá entender como em nível nacional, em face de algumas decisões esparsas" ${ }^{384-385}$.

De outra banda, LuIz LEONARdos e ThOMÁs LEONARDOS entendiam que a proteção estendia-se a todo território nacional, "pois é certo que o art. 38, IX, da Lei n. 4726 proíbe o arquivamento dos contratos de sociedades mercantis sob firma ou denominação idêntica ou semelhante à outra já existente. Trata-se de lei federal, provendo para todo o País. Assim, estende-se a proteção ao nome comercial, sem qualquer restrição",386.

Já em 1976, quando ainda não se falava em Internet, email etc., já ressaltava HERMANO DUVAL que "[r]ealmente, com o aceleramento das comunicações pela rodovia e o avião a jato, a acentuar a figura do crime continuado (...), não faz sentido a redução da

\footnotetext{
${ }^{381}$ FRÓES, Carlos Henrique de Carvalho. Op. cit., 153/154

382 "Manteve-se o critério confederacionista da extensão territorial da proteção ao nome comercial, estabelecido pelo Dec. 916, de 24.10.90, isto é, essa proteção é a nível estadual. O arquivamento do nome comercial protege a sua exclusividade dentro dos limites geográficos da unidade da Federação onde situada a sede principal da empresa" (in A proteção do nome comercial, RDM nº 81/103).

383 "Isto posto o 'nome comercial' e/ou o 'nome empresarial' através do arquivamento de seus atos constitutivos perante a Junta Comercial têm a sua proteção assegurada, dentro do âmbito de jurisdição desta última. Se o interessado não tiver o cuidado de estender a sua proteção às demais unidades da federação é certo que não poderá impedir que outras empresas com nomes iguais ou semelhantes para o mesmo gênero de negócio e/ou atividade arquive os seus atos constitutivos naquela unidade" (in Marcas vs. nome comercial: conflitos, p. 219).

${ }^{384}$ TINOCO SOARES, José Carlos. Nome comercial versus marca. In Propriedade imaterial: direitos autorais, propriedade industrial e bens de personalidade. Eliane Yachoub Abrão (Org.). São Paulo: Senac, 2006, p. 27 ${ }^{385}$ TINOCO SOARES fundamenta-se especialmente no Decreto $n^{\circ} 1.800 / 96$. Não concordamos com tal entendimento, pois o referido Decreto traz apenas normas procedimentais dirigidas às Juntas Comerciais. Logo não existe a aparente antinomia entre o art. 6, do Decreto $\mathrm{n}^{\circ} 1.800 / 96$ e o art. $8^{\circ}$, da CUP. ${ }^{386}$ LEONARDOS, Luiz e LEONARDOS, Thomás. Nome comercial e marca de indústria e comércio, in Revista dos Tribunais, vol. 491, pp. 43/44, $\mathrm{n}^{\mathbf{o}} 39$.
} 
proteção do nome comercial ao âmbito local, sob o pálio do registro de estatutos e contratos sociais nas juntas comerciais estaduais" ${ }^{387}$.

Com esteio na CUP, VERÇOSA tem entendimento diverso. Para este autor: "[n]o que diz respeito à amplitude geográfica da proteção, o nome comercial, nos termos do art. $8^{\circ}$ da União de Paris, será protegido em todos os países participantes deste acordo internacional, sem a obrigação de depósito ou de registro, quer faça ou não parte de uma marca. Ora, a proteção dada a um empresário, ou sociedade empresária, domiciliado ou com sede no Exterior terá como alcance todo o território nacional dos países-membros. Caso venha a se aceitar que a da proteção aos nacionais ficaria na dependência de lei especial a ser futuramente aditada, então, terá sido estabelecida uma situação de desigualdade entre

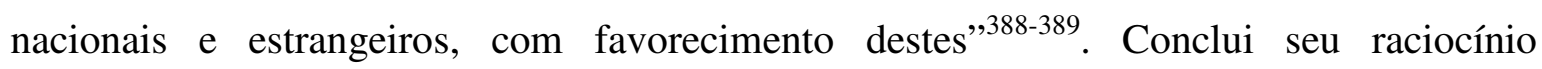
obtemperando que: "a proteção ao nome comercial, uma vez praticados os atos próprios pelo interessado, tem alcance em todo o território do País e dos países-membros signatários da União de Paris" ${ }^{390}$.

Todavia, o STJ tem se manifestado em sentido diametralmente oposto, como se pode verificar em recente julgado, no qual restou consignado que: “[a] proteção legal da denominação de sociedades empresárias, consistente na proibição de registro de nomes iguais ou análogos a outros anteriormente inscritos, restringe-se ao território do Estado em que localizada a Junta Comercial encarregada do arquivamento dos atos constitutivos da pessoa jurídica. Não se há falar em extensão da proteção legal conferida às denominações de sociedades empresárias nacionais a todo o território pátrio, com fulcro na Convenção da União de Paris, porquanto, conforme interpretação sistemática, nos moldes da lei nacional, mesmo a tutela do nome comercial estrangeiro somente ocorre em âmbito nacional mediante registro complementar nas Juntas Comerciais de todos os Estados-membros" ${ }^{391}$ :

De acordo com nosso entendimento, considerado o nome empresarial em sua função identificadora, a proteção não deveria estar limitada a qualquer limite territorial ou ramo de atividade. Todavia, a legislação atualmente em vigor (art. 1.166, do CC) restringe a proteção à circunscrição da Junta Comercial onde foram arquivados os atos constitutivos

\footnotetext{
${ }^{387}$ DUVAL, Hermano. Concorrência desleal. São Paulo: Saraiva, 1976, p. 166/167

${ }^{388}$ VERÇOSA, Haroldo Malheiros Duclerc. Curso de Direito Comercial, cit., p. 261/262

${ }^{389}$ A conclusão a que chega VERÇOSA é da inconstitucionalidade do art. 1.166 do CC (caput e parágrafo único), pois violaria o art. $5^{\circ}$, caput, da $\mathrm{CF} / 1988$, que assegura igualdade de tratamento entre brasileiros e estrangeiros (in Curso de Direito Comercial, p. 262).

${ }^{390}$ VERÇOSA, Haroldo Malheiros Duclerc. Op. cit., p. 262

${ }^{391}$ Cf. $4{ }^{\mathrm{a}}$ T., EDcl nos EDcl no AgRg no REsp 653.609/RJ, Rel. Min. Jorge Scartezzini, j. em 19/05/2005, DJ

27/06/2005 p. 408
} 
ou alterações ou à comarca na qual se localize o Registro Público de Pessoas Jurídicas ${ }^{392}$, como determina o Decreto $n^{\text {o }} 1.800 / 19966^{393}$, o Código Civil ${ }^{394}$ e a IN no $104 / 2007$, do DNRC $^{395}$, podendo ser estendida para outras Juntas mediante procedimento específico.

O mesmo entendimento aplica-se à extensão da proteção, já que, considerado em sua função identificadora, o nome empresarial será protegido independente do ramo de atividade ${ }^{396}$. Em outras palavras, não se aplica a relação de concorrência, pois o que se busca é proteger a própria identidade do empresário, perante não só a clientela, mas também pelos demais agentes que atuam no mercado, como fornecedores, instituições de crédito, distribuidores etc ${ }^{397}$.

Escreveu PONTES DE MiRANDA que: “[a] firma social e a denominação da pessoa jurídica têm a mesma proteção que a firma individual; e tôdas, a mesma proteção do nome civil, seja jurídica, seja física. Por isso mesmo, $a$ ) podem ser protegidas ainda se se trata de comércios, indústria, ou atividades agrícolas. $b$ ) A proteção limitada ao comércio, indústria e agricultura similares já diz respeito à proteção da marca (...) 'as denominações que contiverem elemento de fantasia suscetível de confundi-la com marca anteriormente registrada, para produto do mesmo gênero de negócio, ou para a mesma atividade"”, 398.

No mesmo sentido, merece reprodução excerto do excelente acórdão proferido por CEZAR PELUSO: “[n]em se exige, segundo os princípios, que se trate de conflito onomástico entre pessoas físicas ou jurídicas que exercitam atividades comerciais idênticas, semelhantes, relativas ou afins, reconhecem-no a doutrina (cf. GAMA CERQUEIRA, ob. cit, vol. 1/493, n. 194, e 'Tratado da Propriedade Industrial' t. n/320 e segs., parte 111, Rio

\footnotetext{
${ }^{392}$ V. caso GIDEÕES: $4^{\text {a }}$ T., REsp 555.086/RJ, Rel. Min. Jorge Scartezzini, j. em 14.12.2004, DJ 28.02.2005 p. 327

${ }^{393}$ Cf. Decreto $n^{\circ} 1.800 / 1996$, art. $61, \S 1^{\circ}$ A proteção ao nome empresarial circunscreve-se à unidade federativa de jurisdição da Junta Comercial que procedeu ao arquivamento de que trato o caput deste artigo. ${ }^{394} \mathrm{Cf}$. CC, art. 1.166. A inscrição do empresário, ou dos atos constitutivos das pessoas jurídicas, ou as respectivas averbações, no registro próprio, asseguram o uso exclusivo do nome nos limites do respectivo Estado. Parágrafo único. O uso previsto neste artigo estender-se-á a todo o território nacional, se registrado na forma da lei especial

${ }^{395}$ Cf. IN n ${ }^{\circ} 104 / 2007$, do DNRC, art. 11, § $1^{\circ}$ A proteção ao nome empresarial na jurisdição de outra Junta Comercial decorre, automaticamente, da abertura de filial nela registrada ou do arquivamento de pedido específico, instruído com certidão da Junta Comercial da unidade federativa onde se localiza a sede da sociedade interessada ${ }^{396}$ Segundo Newton SILVEIRA: "por sua natureza, o nome comercial é direito exclusivo absoluto, não limitado ao ramo de atividade, de modo que, ao menos quanto às denominações, não podem coexistir no território nacional duas idênticas" (in Licença de uso de marca e outros sinais distintivos, cit., p. 12) ${ }^{397}$ Segundo Di FRANCO: "[d] i qui la possibilita di coesistenza di analoghi diritti sullo stesso nome, o identico nome:a) sempre che esso sia adoperato oltre i limiti di spazio cui si arresti la notorietà e correlativamente l'espansione industriale o commerciale del primo utente; b) sempre che esso sia speso in differenti campi di attività: e quindi la necessita d'intendere la priorità di uso com riguardo al singolo ambito, locale o di specializzazione, nel quale il nome dovrà sussistere con funzione identificatrice e distintiva” (in Trattato della Proprietà Industriale, cit., p. 362)
} 
de Janeiro, Editora Forense, 1976; TRAJANO D MIRANDA VALVERDE, 'Sociedade por Ações' vol. 1/52, n. 39, Rio de Janeiro, Editora Forense, 1041; WALDEMAR FERREIRA, ‘Tratado de Direito Mercantil' vol. D/89-90, n. 68, inciso IV, Rio de Janeiro São Paulo, Editora Livraria Freitas Bastos, 1939; CARVALHO DE MENDONÇA, 'Tratado de Direito Comercial' vol. 11/185, Rio de Janeiro, Editora Livraria Freitas Bastos, 1934; TÚLIO ASCARELLI, in 'RT', vol. 159/21), e a jurisprudência (cf. decisões sobre os nomes comerciais Vidrobrás, Quimetal, Philips, Esso e JB, citadas por LUIZ LEONARDOS, 'A Proteção ao Nome Comercial no Direito Brasileiro', in 'RT', vol. 450/31 e notas; Apelação Cível n. 115.008, Sexta Colenda Câmara do Tribunal de Justiça de São Paulo apud P.R. TAVARES PAES, 'Propriedade Industrial', São Paulo, Editora Saraiva, 1982, pág. 346; 'RT', vols. 628/88, 623/53, 525/62-66 e 450/262-263, e 'RJTJESP', ed. LEX, vol. 58/134-136). E a razão é que assim seja, porque, visando a lei a discernir, umas das outras, a firmas e denominações comerciais, a fim de evitar confusão, o princípio 'tem inteira aplicação, ainda que diversifique o género de atividade das sociedades, porque a proteção das denominações sociais não pressupõe necessariamente o elemento concorrência, circunstância que apenas influi para agravar a possibilidade de confusão' (GAMA CERQUEIRA, já no parecer in 'RT', vol. 249/37, e no op.ult.cit., pág. 321, grifos nossos). Este é o substrato da interdição das homonímias (homografias e homofonias), cujas consequências da nosas transitam da possibilidade imediata de estorvo no relacionamento mercantil, até aos riscos prováveis de desvio de clientela e de grave promiscuidade dos conceitos públicos. Ninguém ignora a força atritiva ou repulsiva - hoje potenciada pelos veículos de comunicação de massa - exercida por termo preponderante de difundido nome comercial. 'Basta pensar-se em que muitos artigos são preferido, não pela marca de fábrica, ou por algum outro sinal distintivo, inclusive o título de estabelecimento, mas pelo nome do comerciante individual, ou da pessoa jurídica' (PONTES DE MIRANDA, ‘Tratado de Direito Privado', t. XVI/231, par. 1907, n. 2, São Paulo, Editora Revista dos Tribunais, $4^{\mathrm{a}}$ edição, 1977). Concorrência desleal é só consequência extrema de confundibilidade" 399 .

Logo, em sua função identificadora, o nome empresarial deve ser protegido de forma absoluta, mas a proteção é indevidamente limitada à circunscrição da Junta Comercial onde foram arquivados os atos constitutivos ou alterações ou à comarca na qual

\footnotetext{
${ }^{398}$ Op. cit., p. 241

${ }^{399}$ TJSP, $2^{\text {a }}$ Câm. de Direito Privado, AC. 78.942-1, rel. Des. Cezar Peluso, j. 02/12/1986, RJTJESP $131 / 374$
} 
se localize o Registro Público de Pessoas Jurídicas, e o direito de exclusividade é absoluto, ou seja, não se limita ao aspecto concorrência ${ }^{400}$.

Tal regra, contudo, é flexibilizada em relação às firmas, já que não se pode evitar que a pessoa física exerça sua empresa com seu nome civil. Neste caso, em havendo colidência, devem-se agregar ao seu nome outros elementos (designação mais precisa de sua pessoa e/ou gênero de atividade) que o distinga.

Considerado o nome comercial, em sua função econômico-concorrencial, a limitação territorial preestabelecida definitivamente não se lhe aplica, já que tutelado por normas diversas: Constituição Federal, CUP, LPI e CDC. Nesta função, o nome comercial adentra ao campo da propriedade industrial, passando a ser tutelado sob o princípio basilar de repressão à concorrência desleal, como todos os demais direitos de propriedade industrial. Logo, a proteção não será, a priori, internacional, nacional, estadual ou municipal. Não há um limite territorial preestabelecido. O que determinará o âmbito geográfico de proteção é a relação efetiva de concorrência ${ }^{401}$, variando com a distintividade do nome e o grau de conhecimento deste pelo público consumidor ${ }^{402}$.

Para ASCARELLI, "[d]icho ámbito territorial, a su vez, deberá entenderse con relación a la organización empresarial y, por eso, podrá unas veces limitarse a una ciudad (o tal vez a un barrio), otras corresponder al ámbito nacional, otras, incluso, al ámbito internacional" ${ }^{403-404}$.

No mesmo diapasão da lição de ASCARELLI, afina-se o entendimento de GABRIEL FRANCISCO LEONARDOS: “a proteção ao nome comercial deve existir dentro de um âmbito geográfico razoável, nem menor nem maior que o necessário. Razoável, nesse caso, será o âmbito dentro do qual possa existir uma relação de concorrência" 405 .

\footnotetext{
${ }^{400}$ O próprio DNRC assentou entendimento de que "no campo do nome empresarial, a apreciação da colidência, examinada pela Junta Comercial, tanto na hipótese dos nomes completos, como das expressões de fantasia ou características, deve cingir-se ao aspecto formal e aparente, vez que a existência do erro ou confusão não se vincula ao gênero de comércio ou indústria, embora possa influir como agravante dessa condição" (v. Parecer Jurídico DNRC/COJUR/No 016/04).

${ }^{401}$ Para DI FRANCO “[o]nde per l'identificazione del diritto all'uso esclusivo occorrerà seguire la regola empírica del preventivo accertamento della zona entro la quale solo possa sussistere pericolo di confusione" (op. cit., p. 362)

${ }^{402}$ Cf. LeONARDOS, Gabriel Francisco, in A proteção ao nome empresarial, cit., p. 148

${ }^{403}$ ASCARELLI, Tullio. Op. cit., p. 365

${ }^{404}$ Diz, ainda, ASCARELLI: "Ip]ero precisamente porque el nombre comercial se destina a individualizar a un empresario, basta con que su virtud distintiva exista en el ámbito señalado por la natureza y por la esfera territorial de la actividad del empresario individualizado, en lo que podría llamarse ámbito efectivo de su actividad concurrencial; por otra parte, solo en este ámbito viene protegido (y las proposiciones, evidentemente, se complementan); en este ámbito es donde se desarrolla la función individualizadora del nombre comercial" (op. cit., p. 363/364)

${ }^{405}$ Op. cit., p. 28
} 
Temos, portanto, que o nome comercial em sua função econômico-concorrencial tem sua proteção estendida para todo o território em que haja potencial concorrência, não havendo, destarte, limitação territorial preestabelecida, cabendo ao juiz, no caso concreto, aferir a presença da relação de concorrência ${ }^{406}$. Esta relação de concorrência, vale dizer, ao passo que fixa o âmbito territorial de proteção, delimita extensão da proteção à atividade desenvolvida $^{407}$, ou seja, do campo concorrencial ${ }^{408}$.

Vislumbrando a dicotomia entre a legislação aplicável a cada uma das funções do nome empresarial, KARIN GRAU-KUNTZ considerou duas hipóteses de colidência entre nomes: “a) há risco de erro quanto à identidade e não há relação concorrencial entre as empresas. Neste caso estaremos diante de um problema restrito à identidade dos sujeitos de direito e obrigações, objeto de um direito absoluto (direito à identidade), ou seja, válido em todo o território nacional. b) há risco de erro quanto à identidade e há risco de confusão sob o aspecto concorrencial. Neste caso haverá concorrência de tutelas jurídicas e, uma vez que em relação aos seus limites a proteção à identidade é mais abrangente do que a proteção concorrencial, aquela conterá esta" ${ }^{409}$.

Conclui a autora: “[d]aí dizermos que o nome comercial, mesmo quando há relação concorrencial, é direito absoluto, extensível a todo o território nacional. Os fatores 'ramo de atividade' e localização' apresentam-se como um agravante na apuração da colidência" ${ }^{410}$.

\footnotetext{
${ }^{406}$ Ressalte-se que se deve levar em consideração para proteção ao nome empresarial o momento cronológico, já que tanto o objeto da atividade ou o território de atuação podem alterar-se com o passar do tempo.

${ }^{407}$ Vale dizer que a atividade deve ser genericamente considerada, ou seja, deve-se considerar o gênero da atividade desenvolvida adotando-se uma interpretação ampliativa. Por exemplo, se um empresário comercializa produtos alimentícios a proteção é estendida para todos os produtos do gênero, ainda que efetivamente tal empresário comercialize apenas determinados produtos. Esta interpretação toma em consideração a potencialidade de o empresário ampliar sua atuação dentro do gênero de produtos já explorado.

${ }^{408}$ O STJ em alguns casos aplica o princípio da especialidade. Vide, dentre outros: Nome comercial. Marca. Conflito. Mesmo mercado. Especificidade. Precedentes. 1. A proteção ao nome comercial impede o registro posterior de marca igual por terceiro, ainda mais quando no mesmo ambiente de mercado, o setor agropecuário. 2. Recurso especial conhecido e provido. ( ${ }^{\mathrm{a}} \mathrm{T}$., REsp 284.742/SP, Rel. Min. Carlos Alberto Menezes Direito, j. em 20/08/2001, DJ 08.10.2001 p. 212); PROCESSUAL CIVIL. RECURSO ESPECIAL. AUSENCIA DE PREQUESTIONAMENTO. NÃO CONHECIMENTO. COMERCIAL. PROPRIEDADE INDUSTRIAL. USO DE MARCA E NOME COMERCIAL. (...) A empresa titular de marca anteriormente registrada pode impedir que outra empresa use, como nome comercial, expressão que tenha semelhanças gráfica e fonética da aludida marca, quando há, como na hipótese, ${ }_{2}$ identidade entre as atividades exercidas por ambas, tudo a fomentar confusão no espírito do mesmo público-alvo a que ambas se dirigiam e disputavam, com favorecimento, eventual e descabido, a segunda, que foi considerada pelas instancias ordinárias, sem irresignação, neste ponto, como concorrente desleal. Recurso especial não conhecido. $\left(4^{\mathrm{a}} \mathrm{T}\right.$., REsp 32.263/SP, Rel. Min. Cesar Asfor Rocha, j. em 14.10.1996, DJ 18/11/1996 p. 44898)

${ }^{409}$ Op. cit., p. 72

${ }^{410}$ Idem
} 
À conclusão de Grau-KuntZ somam-se as de Gama CerQueIRA, GiaCCHETTA ${ }^{411} \mathrm{e}$ NEWTON SILVEIRA, para o qual: "[p]or sua natureza, o nome comercial é direito exclusivo absoluto, não limitado ao ramo de atividade, de modo que, ao menos quanto às denominações, não podem coexistir no território nacional duas idênticas. No caso de firmas, o princípio se atenua, em face do dever de veracidade na sua formação. Os ramos de atividades e a localização só serão levados em conta em casos de imitação, a fim de se determinar a possibilidade de confusão" ${ }^{412}$.

Considerando que o direito à identidade decorre da personalidade do empresário, trata-se de direito absoluto, de modo que sua proteção não deveria estar limitada a determinado âmbito territorial ou ramo de atividade, atuando o fator concorrência apenas como agravante.

Não obstante, a legislação, equivocadamente, impõe ao nome empresarial, nesta função identificadora, proteção adstrita à circunscrição da Junta Comercial onde foram arquivados os atos constitutivos ou alterações ou à comarca na qual se localize o Registro Público de Pessoas Jurídicas.

Já para a tutela do nome comercial, em sua função econômico-concorrencial, não há limitação territorial preestabelecida (internacional, nacional, estadual ou municipal), sendo que o que determinará o âmbito geográfico de proteção é a relação efetiva de concorrência, que deverá ser aferida no caso concreto.

\section{Medidas administrativas}

\subsection{O recurso ao plenário da Junta Comercial}

Considerando que não poderá haver identidade ou semelhança com outro nome empresarial protegido, no caso de conflitos entre nomes empresariais, é possível a apresentação de recurso ao Plenário da Junta Comercial, nos termos dos artigos 66 e ss. do Decreto $\mathrm{n}^{\mathrm{o}} 1800 / 96$.

\footnotetext{
${ }^{411}$ Em recente dissertação de mestrado apresentada à FADUSP, ainda não publicada, afirmou que "o direito ao nome empresarial, na concepção do artigo 1155 do CC de 2002, é um direito da personalidade do empresário e da sociedade empresária, devendo ser protegido de forma absoluta, sem restrição territorial ao Estado em que arquivados os atos constitutivos ou registrada a inscrição do empresário, sendo que a existência de relação de concorrência entre empresários e/ou sociedades empresárias é fator agravante e não determinante para a imposição de obrigação de abstenção, modificação ou anulação do nome empresarial posterior" (in A proteção do nome empresarial na perspectiva do código civil de 2002: natureza jurídica e concorrência, 2007)

${ }^{412}$ SILVEIRA, Newton. Licença de uso de marca e outros sinais distintivos, cit., p. 12
} 
O recurso deverá ser interposto no prazo de 10 (dez) dias úteis, dirigido ao Presidente da Junta Comercial. O recurso será enviado à Secretaria-Geral que, no prazo de três dias úteis, expedirá notificação às partes interessadas, para se manifestarem, no prazo de dez dias úteis, contados a partir do dia subseqüente à data da ciência.

Decorrido o prazo para contrarrazões, a Secretaria-Geral dará vista do processo à Procuradoria, quando a mesma não for a recorrente, para manifestar-se e restituí-lo, no prazo de dez dias úteis, àquela unidade, que o fará concluso ao Presidente, que e deverá manifestar-se quanto ao recebimento do recurso.

Uma vez admitido o recurso, pelo Presidente, iniciar-se-á a fase de julgamento, que deverá ser concluída no prazo de trinta dias úteis. O Vogal Relator, no prazo de dez dias úteis, elaborará o relatório e o depositará na Secretaria-Geral, para distribuição e conhecimento dos demais Vogais, nos cinco dias úteis subseqüentes, os quais poderão requerer cópia de peças do processo a que se referir.

Será, então, realizada sessão plenária, convocada pelo Presidente, para julgamento do recurso. Da decisão do Plenário da Junta Comercial, caberá recurso ao Ministro de Estado do Desenvolvimento, Indústria e Comércio Exterior, como última instância administrativa.

\subsection{A jurisprudência do DNRC}

Analisando a jurisprudência do DNRC, verificamos algumas diretrizes firmes quanto à análise do conflito entre nome empresarias.

Inicialmente, a apreciação da colidência, examinada pela Junta Comercial, tanto na hipótese dos nomes completos, como das expressões de fantasia ou características, deve cingir-se ao aspecto formal e aparente, vez que a existência do erro ou confusão não se vincula ao gênero de comércio ou indústria, embora possa influir como agravante dessa condição.

No que concerne às expressões de fantasia, temos que: (a) as expressões de fantasia incomuns, desde que contenham fortes condicionantes, podem ser causadoras de colidência entre nomes empresariais ${ }^{413}$; (b) as expressões de fantasia, que possuem evidentes

\footnotetext{
${ }^{413}$ Vide Parecer Jurídico DNRC/COJUR/Nº 016/04 (UNITRADE BRASIL LTDA vs UNITRADE ASSESSORIA EM COMÉRCIO EXTERIOR LTDA); Parecer Jurídico DNRC/COJUR/N ${ }^{\circ} 024$ /04 (DINAPEL INDÚSTRIA E COMÉRCIO DE EMBALAGENS LTDA $v s$ DINAPEL DIVULGADORA NACIONAL DE PRODUTOS EDUCATIVOS LTDA.-ME; Parecer Jurídico DNRC/COJUR/Nº 155/04 (BRASCARGO LOGÍSTICA E TRANSPORTES LTDA $v s$ INTER BRASCARGO ASSESSORIA E
} 
diferenciações gráficas ou fonéticas, não podem ser causadoras de colidência entre nomes empresariais $^{414}$.

Portanto, as denominações sociais podem coexistir perfeitamente, sem provocar erro ou confusão na identificação das sociedades mercantis, quando as expressões preponderantes, que possuem evidentes diferenciações gráficas ${ }^{415}$.

Não são suscetíveis de proteção ou exclusividade os nomes empresariais formados por expressões comuns, de uso generalizado ou vulgar, do vernáculo nacional ou estrangeiro, devendo a análise da colidência ser feita considerando os nomes por inteiro ${ }^{416}$, devendo levar-se em conta, também, a localização das empresas ${ }^{417}$. Ainda, é vedado o registro de nomes empresariais compostos por siglas ou denominações de organismos internacionais $^{418}$.

A respeito do uso do patronímico, o uso de expressões originárias dos nomes dos sócios, de forma completa ou abreviada, sendo permitido por lei, não pode ensejar a colidência entre nomes empresariais ${ }^{419}$.

TRANSPORTE INTERNACIONAL LTDA); Parecer Jurídico DNRC/COJUR/nº 059/98 (SIDERSUL LTDA. vs SIDERSUL COMÉRCIO E INDÚSTRIA LTDA); Parecer Jurídico DNRC/COJUR/Nº 009/03 (INTERTEK COMPONENTES ELETRÔNICOS LTDA vs INTERTEK COMERCIAL LTDA); Parecer Jurídico DNRC/COJUR/N ${ }^{\circ}$ 076/03 (GENERAL ELETRIC DO BRASIL LTDA vs GENELETRIC DO BRASIL LTDA.-ME); Parecer Jurídico DNRC/COJUR/N 088/05 (FILTROS ENGEMAI INDÚSTRIA E COMÉRCIO LTDA $v s$ ENGEMAI MANUTENÇÃO INDUSTRIAL LTDA); Parecer Jurídico DNRC/COJUR/N ${ }^{\circ}$ 128/05 (EXATEC PROCESSAMENTO DE DADOS LTDA. vs EXATEC SERVIÇOS DE DIGITAÇÃO LTDA. - ME); Parecer Jurídico DNRC/COJUR/N 172/03 (COMÉRCIO E INDÚSTRIA CONDUVOLT LTDA. $v s$ MERCANTIL CONDUVOLT PEÇAS E PARTES DE TRANSFORMADORES DE TENSÃO ELÉTRICA LTDA.-EPP); Parecer Jurídico DNRC/COJUR/N ${ }^{\circ}$ 183/03 (VECTRON ELETRÔNICA INDÚSTRIA E COMÉRCIO LTDA. $v s$ VECTRON FERRAMENTARIA DE PRECISÃO LTDA.).

${ }^{414}$ Vide Parecer Jurídico DNRC/COJUR/Nº 033 /04 (ALUMICON SERRALHERIA LTDA. vs ALUMIGON BRASILEIRA INDÚSTRIA E COMÉRCIO LTDA); Parecer Jurídico DNRC/COJUR/N ${ }^{\circ}$ 016/03 (WQUÍMICA E FARMACÊUTICA LTDA $v s$ W. P. QUÍMICA COMÉRCIO E REPRESENTAÇÕES LTDA); Parecer Jurídico DNRC/COJUR/Nº 048/05 (ALLPLAS EMBALAGENS LTDA $v s$ ALLPLAST REPRESENTAÇÕES LTDA); Parecer Jurídico DNRC/COJUR/No 076/05 (WAMA PRODUTOS PARA LABORATÓRIO LTDA $v s$ WANA COMÉRCIO DE PRODUTOS QUÍMICOS LTDA)

${ }^{415}$ Vide Parecer Jurídico DNRC/COJUR/Nº 008/03 (ALCAN EMPREENDIMENTOS LTDA $v s$ ALCAMAR PARTICIPAÇÕES LIMITADA)

${ }^{416}$ Vide Parecer Jurídico DNRC/COJUR/N ${ }^{\circ}$ 004/03 (VETOR EDITORA PSICO-PEDAGÓGICA LTDA vs VETOR PARTICIPAÇÕES E NEGÓCIOS LTDA); Parecer Jurídico DNRC/COJUR/Nº 008/06 (VEGA ENGENHARIA AMBIENTAL S/A $v s$ VEGAS MATERIAIS RECICLADOS LTDA.-ME); Parecer Jurídico DNRC/COJUR/N ${ }^{\circ}$ 046/05 (AUDIT BUSINESS SOLUTIONS LTDA vs AUDIT PLUS SERVIÇOS DE CONTABILIDADE E ASSESSORIA EMPRESARIAL LTDA)

${ }^{417}$ Vide Parecer Jurídico DNRC/COJUR/No 008/06

${ }^{418}$ Vide Parecer Jurídico DNRC/COJUR/No 570/97 (Caso "Mercosul")

${ }^{419}$ Parecer Jurídico DNRC/COJUR/N ${ }^{\circ}$ 037/04 (TOMÉ ENGENHARIA E TRANSPORTES LTDA $v s$ TOMÉ \& TOMÉ ENGENHARIA E CONSTRUÇÃO LTDA); Parecer Jurídico DNRC/COJUR/N ${ }^{\circ}$ 026/03 (LINDEN - ADMINISTRAÇÃO, PARTICIPAÇÕES, EMPREENDIMENTOS E SERVIÇOS LTDA $v s$ LINDEN PATRIMONIAL LTDA.); Parecer Jurídico DNRC/COJUR/Nº 165/03 (STOLTHAVEN SANTOS LTDA vs STOLTI CONSERVAÇÃO DE ELEVADORES LTDA.-ME); Parecer Jurídico DNRC/COJUR/Nº 057/05 (RAIA \& CIA. LTDA vs LAIA \& CIA. LTDA.); Parecer Jurídico DNRC/COJUR/Nº 082/06 
Já em se tratando das siglas, o entendimento predominante do DNRC é no sentido de que não é suscetível de proteção ou exclusividade o uso de letras ou conjunto de letras, desde que não configurem siglas ${ }^{420}$.

É admissível o arquivamento de atos de empresas mercantis cujo nome empresarial é composto por expressão idêntica ou semelhante à de outro já existente, desde que estejam sob a direção, controle ou administração da outra, constituindo grupo industrial, comercial ou de qualquer outra atividade econômica ${ }^{421}$.

Por fim, as Juntas Comerciais entendem que o confronto entre nome e marca escapa à sua competência, de maneira que não analisam o conflito entre nomes empresarias e marcas. O entendimento é de que não integrando a marca o nome empresarial, não compete ao Registro Público de Empresas Mercantis apreciar a questão relativa à proteção da marca, cuja atribuição está afeta ao INPI ${ }^{422}$.

\subsection{A extensão da proteção para outras Juntas Comerciais}

Como dito, a proteção ao nome empresarial decorre automaticamente, do arquivamento da declaração de firma mercantil individual, do ato constitutivo de sociedade mercantil ou de alterações desses atos que impliquem mudança de nome. Não obstante, segundo o art. 61, do Decreto $\mathrm{n}^{\circ}$ 1.800/1996 e art. 1.166, do CC, a inscrição do empresário, ou dos atos constitutivos das pessoas jurídicas, ou as respectivas averbações, no registro próprio, asseguram o uso exclusivo do nome nos limites do respectivo Estado.

A despeito das críticas realizadas a tal preceito, bem como nosso entendimento, quanto ao âmbito de proteção do nome empresarial, cumpre salientar que o CC prevê que o uso estender-se-á a todo o território nacional, se registrado na forma da lei especial (art.

(SUPERMERCADOS BERGAMINI LTDA vs BERGAMINI COMÉRCIO VIRTUAL LTDA); Parecer Jurídico DNRC/COJUR/No 183/00 (ROSSI RESIDENCIAL S.A. vs (SALLES ROSSI

EMPREENDIMENTOS E PARTICIPAÇÕES LTDA.)

${ }^{420}$ Vide Parecer Jurídico DNRC/COJUR/No 042/04 (M.M.L. COMPONENTES LTDA vs MML REPRESENTAÇÃO COMERCIAL E CONSULTORIA LTDA.); Parecer Jurídico DNRC/COJUR/N ${ }^{\circ}$ 013/03 (DLG AUTOMAÇÃO INDUSTRIAL LTDA vs DLG TECNOLOGIA LTDA.-ME); Parecer Jurídico DNRC/COJUR/N ${ }^{\circ}$ 025/03 (G S C - SEGURANÇA ELETRÔNICA LTDA vs GC SECURITY MONITORAMENTO DE ALARMES LTDA.); Parecer Jurídico DNRC/COJUR/Nº 069/06 (DME - D.M. ELETRÔNICA LTDA vs DM ELETRÔNICA DA AMAZÔNIA LTDA.-EPP); Parecer Jurídico DNRC/COJUR/N $\mathrm{N}^{\circ}$ 052/05 (C \& C CASA E CONSTRUÇÃO LTDA vs C \& C AUTO CENTER LTDA.); Parecer Jurídico DNRC/COJUR/Nº 025/06 (AM PRODUÇÕES GRÁFICAS LTDA. vs A. A. M. PRODUÇÕES LTDA.-ME); Parecer Jurídico DNRC/COJUR/N ${ }^{\circ}$ 010/06 (O2 PRODUÇÕES ARTÍSTICAS E CINEMATOGRÁFICAS LTDA $v s$ O2 TECNOLOGIA EM SISTEMAS LTDA)

${ }^{421}$ Cf. Parecer Jurídico Processo MDIC no 52700-002312/02-34 (Caso "BABAÇU") 
1.166, § único), ao passo que o referido Decreto $n^{\circ} 1.800 / 1.996$ dispõe que a proteção ao nome empresarial poderá ser estendida a outras unidades da federação, a requerimento da empresa interessada, observada instrução normativa do DNRC.

Logo, o malsinado registro especial já existe e, viola flagrantemente o disposto no art. $8^{\circ}$, da CUP, que prevê proteção ao nome comercial independentemente de qualquer registro ou formalidade, podendo, assim, gerar conseqüências no campo internacional. Como o art. $8^{\circ}$ da CUP foi expressamente incorporado ao TRIPs, como visto no Cap. IV supra, "a subordinação da proteção ao nome comercial a um registro especial em teoria poderá implicar descumprimento das normas da OMC, com todas as conseqüências que daí podem advir, entre as quais se incluem sanções comerciais" ${ }^{423-424}$.

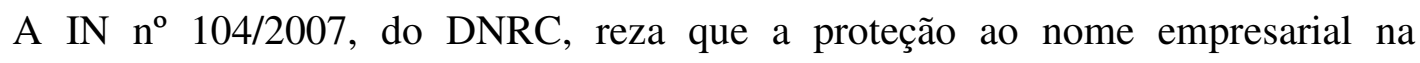
jurisdição de outra Junta Comercial decorre, automaticamente, da abertura de filial nela registrada ou do arquivamento de pedido específico, instruído com certidão da Junta Comercial da unidade federativa onde se localiza a sede da sociedade interessada. Para tanto, deverá ser requerida uma Certidão Simplificada à Junta Comercial do Estado onde se localiza a sede, a qual deverá ser anexada a um Requerimento de Empresário ${ }^{425}$ dirigido à Junta Comercial do Estado onde se pretenda proteger.

Uma vez arquivado o pedido de proteção ao nome empresarial, deverá ser expedida comunicação do fato à Junta Comercial da unidade federativa onde estiver localizada a sede da empresa (art. $11, \S 2^{\circ}$ ).

Este registro, na prática, não atende aos interesses dos empresários, em razão dos custos elevados para extensão a todas as demais Juntas, o que acaba por desincentivar, bem como pelo fato de as Juntas, embora devessem, não realizarem o exame de colidência entre os nomes empresariais de sua circunscrição. Como bem salientou GABRIEL F. LEONARDOS, "a despeito da existência de um registro anterior, a imensa maioria das Juntas Comerciais nega-se a realizar exames de colidência em face da necessidade (verdadeira) da celeridade

\footnotetext{
${ }^{422}$ Vide Parecer Jurídico DNRC/COJUR/No 138/04 (Caso “ULTRA-TEC”); Parecer Jurídico DNRC/COJUR/No 027/03 (Caso “IMPER FORT”); Parecer Jurídico DNRC/COJUR/No 076/04 (Caso "BMC")

${ }^{423}$ Cf. LEONARDOS, Gabriel F. A proteção ao nome empresarial, cit., p. 154

${ }^{424}$ Não obstante, há acórdão do STJ entendendo que "[n]ão se há falar em extensão da proteção legal conferida às denominações de sociedades empresárias nacionais a todo o território pátrio, com fulcro na Convenção da União de Paris, porquanto, conforme interpretação sistemática, nos moldes da lei nacional, mesmo a tutela do nome comercial estrangeiro somente ocorre em âmbito nacional mediante registro complementar nas Juntas Comerciais de todos os Estados-membros" (4 $4^{\mathrm{a}} \mathrm{T}$., EDcl nos EDcl no AgRg no REsp 653.609/RJ, Rel. Min. Jorge Scartezzini, j. em 19/05/2005, DJ 27/06/2005 p. 408)

${ }^{425}$ Assinalando-se o Código 150 e a descrição do ato como "Proteção de Nome Empresarial"
} 
do exame dos requerimentos de atos constitutivos de novas empresas, que é um imperativo da atividade econômica empresarial moderna" ${ }^{426}$.

Não se pode deixar de criticar a ausência de um Cadastro Nacional dos Nomes Empresariais, que facilitaria não só a adoção de novos nomes empresariais pelos empresários, mas também possibilitaria que o empresário tomasse ciência de eventual usurpação ao seu nome empresarial ou outro sinal distintivo. Não se fala aqui em comunicação ex officio da Junta originária às demais, como previa o vetado $\S 2^{\circ}$, do art. 33 , da Lei $n^{\circ} 8.934 / 1994$, mas de uma única comunicação ao DNRC, que se incumbiria de catalogar e disponibilizar a sociedade.

\section{Medidas judiciais no âmbito civil}

\subsection{Generalidades}

O titular de nome de empresa, como visto, tem proteção assegurada contra a adoção de nomes idênticos ou similares adotados por terceiro, independentemente de qualquer registro ou formalidade. A inscrição dos atos constitutivos no respectivo registro estabelece a presunção iuris tantum de que a pessoa física ou jurídica tem direito ao nome comercial $^{427-428}$. Como corolário deste direito, o empresário tem remédios jurídicos para agir contra os violadores de seu direito, de modo a elidir o uso indevido, pleitear a modificação do nome de empresa pelo terceiro e, ainda, auferir valores devidos em razão dos prejuízos que lhe foram causados.

GAMA CERQueIRA sintetiza, com precisão, os requisitos para as ações de proteção ao nome empresarial: "1..$^{\circ}$ ) O princípio exposto aplica-se tanto nos casos em que a identidade ou semelhança é procurada de má-fé como nos casos em que é acidental ou fortuita, porque, naquele, como neste caso, as conseqüências prejudiciais de coexistência de firmas ou denominações idênticas ou semelhantes são as mesmas, podendo ir desde os pequenos embaraços e dificuldades que trazem para a vida normal do comércio às freqüentes confusões de pessoas, de endereços, de negócio e de atividades, até prejuízos mais graves de desvio da clientela ou da repercussão desastrosa que o malogro financeiro

\footnotetext{
${ }^{426}$ In A proteção ao nome empresarial, cit., p. 152

${ }^{427}$ Cf. PONTES DE MiRANDA, Op. cit., t. XVI, p. 239

${ }^{428}$ Em sentido contrário CARVALHO DE MENDONÇA, que entende tratar-se de presunção iuris et de iure (cf. op. cit., $\mathrm{n}^{\circ} 199$, p. 172)
} 
de uma empresa ou sua falta de idoneidade pode ter sobre o crédito e a reputação de outra que com ela se confunda;

2. $\left.{ }^{\circ}\right)$ Não importa que diversifique o gênero de comércio ou indústria explorados porque a proteção do nome comercial não pressupõe necessariamente o elemento concorrência, circunstância que, entretanto, influi para agravar a possibilidade de confusão e suas consequências;

3..$^{\circ}$ A possibilidade de confusão pode verificar-se não só entre as sociedades da mesma natureza como entre sociedades de natureza diversa, como uma sociedade anônima e uma sociedade por quotas de responsabilidade limitada, constituída sob denominação particular ou uma sociedade desta espécie que adote firma e outras sociedades que também se designem por este meio;

4..$^{\circ}$ O critério de apreciação da possibilidade de confusão deve variar, conforme se trate de firmas comerciais singulares, firmas coletivas e denominações sociais;

5. ${ }^{\circ}$ ) Tratando-se de comerciantes em nome individual, êsse critério, forçosamente terá de ser mais benigno, levando-se em conta o acaso da homonímia entre pessoas que têm o direito de usar o mesmo nome, porque, sendo o comerciante singular obrigado a exercer o comércio sob seu próprio nome civil, por extenso ou abreviado, a semelhança das firmas não pode ser afastada;

6. $\left.{ }^{\circ}\right)$ O mesmo já não se dá quando se trata de firmas de sociedades e, sobretudo, de denominações, porque, em relação às primeiras, é mais difícil a homonímia completa entre sócios de duas sociedades, e, em relação às segundas, os interessados gozam de ampla liberdade na escolha e composição do nome social, podendo adotar denominações inteiramente diversas de outras já existentes;

7. $\left.{ }^{\circ}\right)$ Quanto às denominações das sociedades em particular é necessário distinguir entre as que são compostas de expressões genéricas, mais ou menos vulgares, as quais devem ser tomadas em seu conjunto para apreciar possibilidade de confusão, e as que se distinguem por uma expressão característica, caso em que a questão deve ser apreciada em relação a esta expressão ${ }^{429}$, não se levando em conta os elementos comuns que entram na composição das denominações em conflito, porque seu elemento distintivo é muito relativo e fica anulado pela identidade ou semelhança das expressões características pelas quais as sociedades se tornam conhecidas e passam a ser designadas pelo público" ${ }^{430}$.

\footnotetext{
${ }^{429}$ Nesse sentido TJSP, $3^{\text {a }}$ Câm. de Direito Privado "B”, AC n ${ }^{\circ}$ 261.880-4/4, rel. Des. Marcelo Rimola, j. 27/06/2008

${ }^{430}$ GAMA CERQUEIRA, João da. Op. cit., v. 2, parte III, p. 322.
} 
As principais ações possíveis, na esfera cível, para tutela do nome empresarial são: a ação de abstenção de uso, a ação de modificação do nome e a ação indenizatória.

\subsection{Ação de abstenção de uso}

Como conseqüência do monopólio do nome empresarial, tem o empresário direito de inibir seu uso por terceiros, ainda que de boa-fé. Logo, a ação de abstenção com preceito cominatório, ou inibitória, de rito ordinário, visa à condenação do réu a abster-se de usar o nome empresarial, sob pena de multa cominatória, usualmente diária.

Esta multa, que tem o condão de exercer pressão psicológica sobre o réu, deve ter o valor significativamente alto, justamente porque tem natureza inibitória ${ }^{431}$. Assim, a característica fundamental da pena reside no exagero do algarismo ${ }^{432}$. Seu valor deverá ser exorbitante, desproporcional ao conteúdo econômico da causa, mas adequado à pessoa do executado ${ }^{433}$. Vale dizer, o devedor deve sentir ser preferível cumprir a obrigação na forma específica a pagar o alto valor da multa fixada pelo juiz ${ }^{434}$

Como informou Pontes de MiRAnda, "[c]om o pedido de proibição do uso da firma ou denominação, pode o comerciante cumular o pedido de indenização ${ }^{435}$. (...) Para a propositura da ação de abstenção ou de preceito cominatório, como para a ação de condenação específica, não é preciso que se alegue dano, ou outro interesse que o da exclusividade mesma" 436 .

O cumprimento da sentença da ação de abstenção de uso far-se-á conforme os arts. 461 , do $\mathrm{CPC}^{437}$, o qual diz que na ação que tenha por objeto o cumprimento de obrigação de fazer ou não fazer, o juiz concederá a tutela específica da obrigação ou, se procedente o pedido, determinará providências que assegurem o resultado prático equivalente ao do adimplemento.

Para a efetivação da tutela específica ou a obtenção do resultado prático equivalente, poderá o juiz, de ofício ou a requerimento, determinar as medidas necessárias, tais como a imposição de multa por tempo de atraso, busca e apreensão, remoção de pessoas e coisas, desfazimento de obras e impedimento de atividade nociva, se necessário

\footnotetext{
${ }^{431}$ NeRY JUNIOR, Nelson et al. Código de Processo Civil comentado e legislação processual civil extravagante em vigor. São Paulo: Revista dos Tribunais, 1997, p.673.

${ }^{432}$ Assis, Araken de. Cumprimento da sentença, Rio de Janeiro: Forense, 2.006, p. 224

${ }^{433}$ Ibidem

${ }^{434}$ NERY JUNIOR, Nelson et al. Op. cit., p. 673

${ }^{435}$ No mesmo sentido CARVALHO DE MENDONÇA, Op. cit., p. 175

${ }^{436}$ PONTES DE MiRANDA, Op. cit., t.. XVI, p. 240
} 
com requisição de força policial ( $\$ 5^{\circ}$, do art. 461). Este rol não é exaustivo, de maneira que o juiz poderá determinar quaisquer medidas sub-rogatórias (obtenção de resultado prático equivalente) ou medidas coercitivas.

A tutela antecipada poderá ser requerida para evitar dano irreparável ou de difícil reparação, com base no art. 209, § $1^{\circ}$, da LPI, cumulado com art. 461, § $3^{\circ}$, do CPC. A tutela específica pleiteada encontra-se prevista em Lei especial, notadamente no art. 209 da LPI, aplicando-se, de forma complementar, as demais disposições do micro-sistema das medidas antecipatórias como aquelas previstas no parágrafo $3^{\circ}$ do art. 461, do CPC. A nosso ver, as tutelas previstas no art. 209 da LPI e art. 461 do CPC não se confundem com aquela prevista no art. 273. Portanto, são diferentes os requisitos de uma e de outra tutela, bem como que há evidente diferenciação entre o grau de cognição sumária vertical.

Em havendo tutela específica, com requisitos próprios, como aceitar a aplicação de regra geral (não específica) em detrimento à plena aplicabilidade da tutela específica? A situação complica-se ainda mais se atentarmos para o fato de que o art. 273 tem requisitos que ensejam um maior grau de certeza quanto à verossimilhança do direito do autor, fato que aumenta a exigência do órgão jurisdicional quanto aos fatos constitutivos do direito do autor; além da exigência de prova inequívoca.

A lei especial que disciplina o regime jurídico da propriedade industrial prevê a concessão de medida liminar, apenas verificada a ocorrência da violação do direito protegido ou do ato de concorrência desleal. Em outras palavras, o art. 209 da LPI prevê uma tutela inibitória específica $\left(\S 1^{\circ}\right)$ para impedir a continuação ou a repetição de violação a direito de propriedade ou atos de concorrência desleal, bastando, para seu deferimento, a constatação do ato ilícito. Essa particularidade do regime jurídico da propriedade industrial afasta a incidência do art. 273 do $\mathrm{CPC}^{438}$.

\subsection{Ação anulatória de inscrição do nome empresarial}

O titular do nome empresarial tem, ainda, o direito de obrigar a modificação de nome idêntico ou semelhante, suscetível de induzir terceiro a erro. "O fim da lei é evitar a

\footnotetext{
${ }^{437}$ Cf. art. 475-I, do CPC

${ }^{438}$ Nesse sentido TJSP, $9^{\text {a }}$ Câm. de Direito Privado, AC. n $^{\circ}$ 130.981.4/4, rel. Des.Ruster Oliveira, j. 08/02/2000
} 
concorrência ilícita, mediante o uso de uma firma criada para gerar confusão, prejudicando o titular da firma semelhante já inscrita", salientou CARVALHO DE MENDONÇA ${ }^{439}$.

O nome empresarial, em atenção ao princípio da novidade, deve distinguir-se de qualquer outro inscrito, cabendo ao prejudicado requerer, além da abstenção, a anulação da inscrição do nome empresarial, conforme art. 1.167 do Código Civil. "As matrículas obtidas contra a lei são cassáveis", dizia PONTES DE MIRANDA ${ }^{440}$.

Destarte, o titular do nome empresarial que vier a tomar conhecimento de inscrição de empresário ou arquivamento de ato constitutivo com firma ou denominação idêntica ou suscetível de causar confusão, poderá requerer em juízo a modificação do nome, ação esta que, segundo o referido art. 1.167, é imprescritível.

Esta ação deverá ser proposta somente contra aquele que adotou o nome confundível, sendo a Junta Comercial parte ilegítima para figurar no pólo passivo das ações de modificação do nome, consoante entendimento consolidado na jurisprudência ${ }^{441}$.

\subsection{Ação indenizatória}

Como decorrência da usurpação do nome, o empresário pode exigir indenização por perdas e danos. A Lei da Propriedade Industrial, que rege a matéria, é clara quanto ao cabimento da indenização por perdas e danos e lucros cessantes, oriundos de violação de direitos de propriedade industrial e atos de concorrência desleal, nos termos de seus artigos 207 a 210.

O fundamento legal é o art. 209, da LPI, que ressalva ao prejudicado o direito de haver perdas e danos em ressarcimento de prejuízos causados por atos de violação de direitos de propriedade industrial e atos de concorrência desleal não previstos nesta Lei, tendentes a prejudicar a reputação ou os negócios alheios, a criar confusão entre estabelecimentos comerciais, industriais ou prestadores de serviço, ou entre os produtos e serviços postos no comércio.

Tal dispositivo é complementado pelos artigos $208^{442}$ e $210^{443}$, da mesma Lei, aplicando-se, a fortiori, a regra geral previstas nos artigos $186^{444} \mathrm{c} / \mathrm{c} 927^{445}$, do CC.

\footnotetext{
${ }^{439}$ CARVAlho De MendonÇA, Op. cit., p. 176

${ }^{440}$ Op. cit., p. 253

441 JUNTA COMERCIAL. AÇÃO SOBRE USO DE NOME COMERCIAL REGISTRADO. PARTE

LEGITIMA. Não tendo a Junta Comercial interesse na demanda entre sociedades comerciais sobre nome comercial, ainda que registrado, e ela parte ilegitima passiva na ação ordinaria com preceito cominatorio para a alteração do nome e cancelamento do registro. Recurso especial provido.
} 
Não há a necessidade de demonstração de efetivo dano para que seja determinada a obrigação de indenizar. Trata-se, pois, de dano apodíctico. A obrigação surge com a ilicitude, ou seja, com a usurpação do nome e com a possibilidade de engano por parte do consumidor. Antonio BENTO DE FARIA ensinou que "a toda ofensa de direito de outrem corresponde, portanto, uma obrigação civil de repará-lo (...). Por conseguinte as perdas e danos consistem nas indenizações que são devidas à pessoa lesada pela perda sofrida em seu patrimônio (damnum emergens) ou pelos lucros de que foi privada (lucrum cessans), por efeito de fato ilícito. Por 'damno' entende-se qualquer prejuízo que alguém sofrer na sua pessoa ou patrimônio, quer este seja 'material' ou resulte de um 'lucro cessante", 446.

GAMA CERQUEIRA também aduzia que "[a] simples violação do direito obriga à satisfação do dano, na forma do art. 159 do Código Civil ${ }^{447}$, não sendo, pois, necessário, a nosso ver, que o autor faça prova dos prejuízos no curso da ação. Verificada a infração, a ação deve ser julgada procedente, condenando-se o réu a indenizar os danos emergentes e os lucros cessantes (código civil, art. 1.059), que se apurarem na execução. E não havendo elementos que bastem para se fixar o quantum dos prejuízos sofridos, a indenização deverá ser fixada por meio de arbitramento, de acordo com o art. 1.553 do Código Civil" ${ }^{448}$.

Não é necessária, assim, a efetiva comprovação de dano material, sendo certo que este dano advém do próprio ato ilícito, ou seja, os atos de concorrência desleal per si dão ensejo à indenização, a qual deve, além de ressarcir o titular do direito violado, inibir que o contrafator volte a realizar estes atos predatórios e desleais. Este entendimento sedimentouse em nossas cortes, especialmente no STJ ${ }^{449}$.

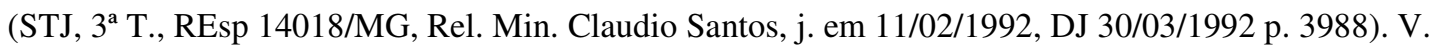
também TFR, AC 82.017-RJ, rel. Min. Armando Rollemberg, j. 06/06/1983, DJ 15/03/1984.

${ }_{442}$ Art. 208 - A indenização será determinada pelos benefícios que o prejudicado teria auferido se a violação não tivesse ocorrido

${ }^{443}$ Art. 210 - Os lucros cessantes serão determinados pelo critério mais favorável ao prejudicado, dentre os seguintes:

I - os benefícios que o prejudicado teria auferido se a violação não tivesse ocorrido; ou

II - os benefícios que foram auferidos pelo autor da violação do direito; ou

III - a remuneração que o autor da violação teria pago ao titular do direito violado pela concessão de uma licença que lhe permitisse legalmente explorar o bem.

${ }^{444}$ Art. 186. Aquele que, por ação ou omissão voluntária, negligência ou imprudência, violar direito e causar dano a outrem, ainda que exclusivamente moral, comete ato ilícito

${ }_{445}$ Art. 927 . Aquele que, por ato ilícito (arts. 186 e 187), causar dano a outrem, fica obrigado a repará-lo.

${ }^{446}$ BENTO DE FARIA, Antonio. Op. cit., p. 357

${ }^{447}$ O CC/2002 traz norma similar nos termos dos citados art. $186 \mathrm{c} / \mathrm{c} 927$

${ }^{448}$ GAMA CERQUeIRA, João da. Ob. cit., vol. III, p. 286

${ }^{449}$ Nesse sentido, vide $3^{\text {a }}$ T., REsp 466.761/RJ, Rel. Min. Nancy Andrighi, j. em 3/4/2003 e STJ, $4^{\text {a }}$ T., REsp

15.424-0/SP, Rel. Min. Ruy Rosado de Aguiar, DJ de 13/02/1995, p. 2242 
O quantum debeatur deverá ser apurado em fase de liquidação de sentença, por arbitramento ${ }^{450}$, devendo os lucros cessantes ser fixados com o parâmetro mais favorável ao titular do direito violado, dentre aqueles previstos nos incisos do aludido art. 210, da LPI.

Ademais, o uso indevido de nome empresarial também poderá dar azo à indenização pelos danos morais causados ao empresário ou sociedade empresária. Entende-se dano moral como o resultado da violação de um ou mais direitos inerentes à personalidade de um sujeito de direito ${ }^{451}$, sendo que a responsabilização do agente operase por força do simples fato da violação (“danum in re ipsa”).

A reparação do dano moral baliza-se na responsabilização do ofensor pelo simples fato da violação; na desnecessidade da prova do prejuízo e, na atribuição à indenização de valor de desestímulo a novas práticas lesivas ${ }^{452}$. Isso porque a violação ao nome comercial pode afetar a exposição do empresário no campo concorrencial, em razão da perda da credibilidade e, principalmente, pelos danos à imagem corporativa. Assim, plenamente cabível indenização por danos morais em se tratando de direitos de propriedade industrial ou atos de concorrência desleal, como tem reconhecido a jurisprudência ${ }^{453}$.

No tocante às sociedades, não é despiciendo ressaltar que já é pacífico na jurisprudência o entendimento de que "[a] pessoa jurídica pode sofrer dano moral” quando tem violada a sua honra objetiva, nos termos da Súmula 227 , do STJ ${ }^{454}$, máxime com o advento do vigente Código Civil que assim dispôs expressamente, em seu art. $52{ }^{455}$.

Saliente-se, outrossim, a condenação em indenizar os danos morais deve considerar também o caráter punitivo e pedagógico, como vem reconhecendo a jurisprudência ${ }^{456}$, de modo a desestimular a prática de outros ilícitos similares.

Por derradeiro, ressalte-se que a ação de indenização poderá ser proposta cumulada com a ação de modificação e/ou abstenção de uso do nome, o que, na verdade, é o mais comum.

\footnotetext{
${ }^{450}$ Com a realização de perícia contábil, para a análise dos livros. Cf. arts. 475-C e 475-D, do CPC

${ }^{451}$ BRebBia, Roberto H. El daño moral, $2^{\mathrm{a}}$ ed., B. Aires, Orbir, 1967, p. 76.

${ }^{452}$ BITTAR, Carlos Alberto. Reparação civil por danos morais, $2^{a}$ ed., São Paulo: Revista dos Tribunais, 1993, pp. $198 / 226$

${ }^{453}$ Vide STJ, $3^{\text {a }}$ T., REsp 466761-RJ, Rel. Min. Nancy Andrighi, DJ 04/08/2003, p. 295

${ }^{454}$ No mesmo sentido, “[a]o adquirir personalidade, a pessoa jurídica faz jus à proteção legal e estatal à sua honra objetiva, considerada assim a reputação que goza em sua área de atuação. O dano moral puro é aquele em que a ofensa que lhe deu causa não traz reflexos patrimoniais, independendo, sua reparação, da existência de prejuízos econômicos oriundos do ataque irrogado" (TJDF, $3^{\text {a }}$ Câm., AC n. " 41.293/96, , rel. Des. Nancy Andrighi).

${ }^{455}$ Art. 52. Aplica-se às pessoas jurídicas, no que couber, a proteção dos direitos da personalidade.
} 


\subsection{A prescrição das ações envolvendo o nome empresarial.}

\subsubsection{A prescrição das ações de abstenção de uso}

O prazo prescricional das ações envolvendo nomes empresariais sempre foi tema espinhoso, de modo que as opiniões variaram ao longo dos anos. No tocante à ação de abstenção três correntes, fulcradas nos diferentes entendimentos quanto à natureza do nome comercial, destacavam-se. A primeira, fundamentada no direito de propriedade, dispunha que o prazo seria de 05 anos, com fundamento no inc. IX, do $\S 10$, do art. 178, do Código Civil de 1.916, que preceituava que prescreve em cinco anos a ação por ofensa ou dano causado a direito de propriedade, contado o prazo da data em que se deu a mesma ofensa ou dano.

FRÓES dizia, ainda, que por se tratar o arquivamento dos atos constitutivo de ato administrativo, aplicar-se-ia, por analogia, o prazo de 5 anos estabelecido no Decreto $\mathrm{n}^{\circ}$ 20.910/32, relativo às ações contra a Fazenda Pública ${ }^{457}$.

Aqueles que tinham o direito ao nome como direito real, pugnavam pela aplicação do prazo prescricional de 10 anos entre presentes e de 15 anos entre ausentes, previsto no art. 177, do Código Civil de 1.916.

Por outro lado, aqueles que tinham o direito ao nome como pessoal, defendiam o prazo prescricional de 20 anos, também previsto no referido art. $177^{458}$. Esta corrente prevaleceu, tendo sido inclusive objeto da Súmula $\mathrm{n}^{\circ} 142$, do STJ, hoje cancelada ${ }^{459}$. Porém, a questão remanesceu controversa, havendo julgados aplicando o prazo decenal e prazo vintenário ${ }^{460}$, prevalecendo aquele nos julgados mais recentes ${ }^{461}$.

\footnotetext{
${ }^{456}$ V. STJ, $3^{\text {a }}$ T., REsp 355.392/RJ, Rel. Min. Nancy Andrighi, Rel. p/ acórdão Min. Castro Filho, j. em 26.03.2002; STJ, REsp 521.434/TO, Rel. Min. Denise Arruda, 1a T., j. em 04.04.2006, DJ 08.06.2006 p. 120 ${ }^{457}$ Op. cit., p. 319

${ }^{458}$ Nesse sentido v. REsp 133.453/PR, Rel. Min. Waldemar Zveiter, $3^{\text {a }}$ T., j. em 31.03.1998, DJ 01.06.1998 p. 85; REsp 33.787, Rel. Min. Waldemar Zveiter, $3^{\text {a }}$ T., j. em 08/06/1993, DJ 28/06/1993 p. 12890

${ }^{459}$ Em 12.05.1999, no julgamento da ação rescisória $\mathrm{n}^{\circ} 512$

${ }^{460}$ V. STJ, $3^{\mathrm{a}}$ T., AgRg no REsp 207052/SP, Rel. Min. Nancy Andrighi, j. em 22/05/2001, DJ 25/06/2001 p. 169; $3^{\mathrm{a}}$ T., REsp 40.021/SP, Rel. Min. Carlos Alberto Menezes Direito, j. em 14.05.2002, DJ 26/08/2002 p. 211

${ }^{461}$ V. STJ, $3^{\mathrm{a}}$ T., REsp 418580/SP, Rel. Min. Carlos Alberto Menezes Direito, j. em 11/02/2003, DJ 10.03.2003 p. 191; $3^{\mathrm{a}}$ T., AgRg no REsp 981.004/MG, Rel. Min. Nancy Andrighi, j. em 14/11/2007, DJ 26/11/2007 p. 193
} 
Com o advento do atual CC a questão da prescrição foi definitivamente resolvida, aplicando-se o prazo prescricional de 10 anos, previsto em seu art. $205^{462}$, uma vez que inexiste previsão legal expressa quanto ao prazo prescricional da pretensão inibitória.

\subsubsection{A prescrição das ações de modificação}

$\mathrm{O}$ art. 1.167, do CC, reza que cabe ao prejudicado, a qualquer tempo, ação para anular a inscrição do nome empresarial feita com violação da lei ou do contrato.

Inicialmente, observe-se a impropriedade da redação, ao referir-se à anulação da inscrição do nome empresarial. Como vimos, não há registro especial para os nomes empresariais, exsurgindo sua proteção da inscrição do empresário individual ou arquivamento dos atos constitutivos das sociedades. Portanto, não há inscrição do nome a ser anulada. A ação cabível, desta forma, é a ação de modificação do nome empresarial, a ser movida exclusivamente contra o empresário ou sociedade que tenha adotado nome confundível ${ }^{463}$.

A imprescritibilidade da ação de modificação do nome deriva, certamente, do tratamento do nome empresarial como direito de personalidade, que permeou sua disciplina no CC. Daí, o porquê de concordarmos com a imprescritibilidade da ação de modificação do nome, especialmente considerando sua função identificadora, de modo a tutelar a reputação e o direito ao crédito do empresário, máxime em se tratando de firmas $^{464}$.

Ora, o nome de empresa é tutelado, já destacamos, ainda que o interesse seja exclusivamente moral, bastando, p. ex., que "possa haver confusão e ter má fama a outra firma ou empresa" ${ }^{465}$.

Contudo, aqueles que têm o nome de empresa como direito pessoal ou direito de propriedade ${ }^{466}$, entendem que o prazo prescricional deve ser de 10 anos, considerando a regra geral do art. 205, do CC, reservando a perpetuidade apenas aos casos de má-fé.

\footnotetext{
${ }^{462}$ Nesse sentido, v. NERY JUNIOR, Nelson et al. Novo Código Civil e legislação extravagante anotados. São Paulo: Revista dos Tribunais, 2002, p.117

${ }^{463}$ As Juntas Comerciais são partes ilegímas nas ações de modificação do nome empresarial (v. STJ, $3^{\mathrm{a}}$ T., REsp 14018/MG, Rel. Min. Claudio Santos, j. em 11/02/1992, DJ 30/03/1992 p. 3988)

${ }_{464}$ Quanto às firmas, o Decreto $\mathrm{n}^{\circ}$ 916/1890, que criou o registro das firmas e razões comerciais, dispunha no $\S 2^{\circ}$, do art. 10 que "a propriedade da firma é imprescritível e só deixará de subsistir no caso do art. 9", que tratava da cessão do comércio, dissolução e liquidação da sociedade.

${ }^{465}$ Cf. PONTES DE MIRANDA. Op. cit., t. XVII, p. 241

${ }^{466}$ Nesse sentido TINOCO SOARES, in Novo Código Civil..., cit., p. 58
} 


\subsubsection{A prescrição das ações indenizatórias}

Conquanto muito se discutisse o prazo prescricional das ações de abstenção de uso, era pacífico o entendimento de que as ações para reparação de danos prescreviam em 5 anos, aplicando-se a regra do art. 178, § 10, inc. IX do Código Civil de 1.916, que limitava em cinco anos o prazo para a ação de reparação de danos causados pelo uso indevido ${ }^{467}$. Nesse sentido, a Súmula n 143, do STJ, segundo a qual "[p]rescreve em cinco anos a ação de perdas e danos pelo uso de marca comercial" ${ }^{468}$.

Entrementes, o CC não possui dispositivo similar, sendo necessário interpretar se se aplica o prazo decenal previsto no art. 205, ou o prazo trienal, do art. 206, $\S 3^{\circ}$, inc. V, relativo à pretensão de reparação civil.

A ABPI, em sua Resolução no 24, entende ser aplicável o prazo de 10 anos, do art. 205, para afastar dificuldades de interpretação com o prazo prescricional de 03 anos previsto no art. 206, § 3o, inc. V, do CC. Uma interpretação sistêmica do micro-sistema de proteção à propriedade industrial também aconselha a aplicação do prazo decenal. Vejamos, nesse sentir, o disposto no art. 225, da LPI, segundo o qual "[p]rescreve em 5 (cinco) anos a ação para reparação de dano causado ao direito de propriedade industrial”.

\section{Medidas judiciais no âmbito criminal}

A ação penal acerca do nome comercial encontra fundamento no art. 195, inc. V, da LPI, que tipifica como crime de concorrência desleal o uso indevido de nome comercial, título de estabelecimento ou insígnia alheios ou vende, expõe ou oferece à venda ou tem em estoque produto com essas referências. A pena prevista é de detenção, de 3 (três) meses a 1 (um) ano, ou multa.

Verifica-se, portanto, que o legislador brasileiro optou por proteger o nome de empresa dentro do âmbito de repressão à concorrência desleal, especificamente dentro do Direito Penal.

\footnotetext{
${ }^{467}$ Vide $4^{\text {a }}$ T., REsp 2476/RJ, Rel. Min. Antônio Torreão Braz, j. em 16/05/1995, DJ 12/06/1995 p. 17626; $4^{\text {a }}$ T., REsp 30727/SP, Rel. Min. Ruy Rosado de Aguiar, j. em 18/10/1994, DJ 13/03/1995 p. 5299; $4^{\text {a }}$ T., REsp 34.862/SP, Rel. Min. Ruy Rosado de Aguiar, j. em 25/10/1994, DJ 21/11/1994 p. 31771; 3 $3^{\text {a }}$ T., REsp 31.304/SP, Rel. Min. Eduardo Ribeiro, j. em 29/03/1993, DJ 26/04/1993 p. 7207; $2^{\text {a }}$ Seção, REsp 19.355/MG, Rel. Min. Nilson Naves, j. em 28/10/1992, DJ 01/02/1993 p. 434; 3ª T., REsp 10.564/SP, Rel. Min. Nilson Naves, Rel. p/ Acórdão Min. Eduardo Ribeiro, j. em 26/11/1991, DJ 09/03/1992 p. 2573 468 2a Seção, j. em 14/06/1995, DJ 23/06/1995 p. 19648
} 
A usurpação do nome é rara, sendo mais freqüente "o uso de nome que imite o alheio, com o fim de estabelecer confusão e induzir o público em êrro, o que constitui ato de concorrência desleal, ilícito civil, e não crime" ${ }^{469}$.

Trata-se de crime formal, ou seja, que se consuma independentemente da superveniência ou não de um resultado, e esta ação só tem cabimento em se tratando de nome comercial objetivo, visto que o titular da firma ou denominação só dispõe da ação para obter a modificação do nome idêntico ou semelhante ao seu de maneira a evitar confusão $^{470}$.

A LPI considera, também, crime reproduzir ou imitar, de modo que possa induzir em erro ou confusão, armas, brasões ou distintivos oficiais nacionais, estrangeiros ou internacionais, sem a necessária autorização, no todo ou em parte, nome comercial e insígnia, ou usar essas reproduções ou imitações com fins econômicos. A pena cominada é de detenção, de 1 (um) a 3 (três) meses, ou multa.

\section{O conflito entre nome empresarial e outros sinais distintivos}

Como dito linhas acima, a jurisprudência, ao longo dos anos, balizou a proteção ao nome empresarial, estabelecendo que o direito ao uso exclusivo do nome comercial em todo território nacional não esta sujeito a registro no INPI, e surge tão-só com a constituição jurídica da sociedade, através do registro de seus atos constitutivos no registro do comercio, devendo prevalecer o registro do nome comercial feito com anterioridade, no caso de firmas idênticas ou semelhantes e objeto social semelhante, que possibilite confusão ${ }^{471}$.

Logo, a jurisprudência pátria é uníssona quanto à exclusividade de uso de nome empresarial, notadamente naqueles casos de confrontamento com nome empresarial posterior $^{472}$. Mas, e quanto ao conflito do nome de empresa com outros sinais distintivos?

Vimos que os sinais distintivos guardam relação de interdependência, havendo proteção contra seu uso para formar outro sinal distintivo, ainda que de natureza diferentes, com fundamento nas normas de repressão à concorrência (principalmente art. $2^{\circ}$, inc. $\mathrm{V} \mathrm{e}$ 195, incs. III, IV e V, da LPI e art. 10 bis, da CUP), pois se o nome empresarial tiver como elemento característico expressão idêntica ou semelhante àquela que constitua marca ou

\footnotetext{
${ }^{469}$ GAMA CerQUEIRA, João da. Op. cit., v. 2, parte III, p. 330

${ }^{470}$ Nesse sentido GAMA CERQUeIRA, Op. cit., v. 2, parte III, p. 331

${ }^{471}$ Cf. STJ, $4^{\text {a }}$ T., REsp 6.169/AM, Rel. Min. Athos Carneiro, j. em 25.06.1991, DJ 12.08.1991 p. 10557
} 
título de estabelecimento ou qualquer outro sinal distintivo alheio, poderá induzir o público em erro ou confusão.

Como destacou Duval, "o conflito de nome comercial, em que se inclui o título de estabelecimento e a insígnia, gira em torno da apropriação, total ou parcial, do mesmo sinal distintivo alheio famoso, com o indisfarçável intuito de desviar a clientela a ele subjacente, caracterizando o ato de CD" 473

Por conseguinte, é vedado o uso de nome empresarial para compor outros sinais distintivos (além da marca), tais como títulos de estabelecimento, insígnias e nomes de domínio não pertencentes ao seu titular. Assim, trataremos, a seguir, do conflito entre os nomes empresariais e outros sinais distintivos.

\subsection{Nome empresarial vs marca}

Já tivemos a oportunidade de salientar que marca e nome empresarial são institutos distintos, ambos tutelados pelo ordenamento jurídico brasileiro ${ }^{474}$, mas que dada a relação existente entre eles no universo mercantil, perfeitamente viável a pretensão de abstenção de uso da expressão designativa da marca em nome comercial $^{475}$ e vice-versa ${ }^{476-477 .}$. Porém, é fundamental a verificação da possibilidade de confusão no mercado devendo haver relação de concorrência, diferentemente do que ocorre no conflito entre nomes, caso em que o fator concorrência atua apenas como agravante. Ou seja, aos conflitos entre marcas e nomes de empresa, aplicam-se os princípios de proteção às marcas ${ }^{478}$.

Tendo em vista estas premissas, extraí-se da jurisprudência critérios usualmente aceitos para solucionar o conflito entre nomes empresariais e marcas. O primeiro deles diz

\footnotetext{
${ }^{472}$ Cf. STJ, $3^{\text {a }}$ T., AgRg 462.456/SP, Rel. Min. Carlos Alberto Menezes Direito, DJ de 23/06/2003, p. 00357

${ }^{473}$ DuvAL, Hermano. Concorrência desleal. São Paulo: Saraiva, 1976, p. 165

${ }^{474}$ V. STJ, 4a T., REsp 40.190/RJ, Rel. Min. Sálvio de Figueiredo Teixeira, j. em 19/08/1997, DJ 29/09/1997 p. 48207

${ }^{475}$ Cf. STJ, $3^{\text {a }}$ T., REsp 42.424 / SP, Rel. Min. Costa Leite, DJ 19.12.1994 p. 35309

${ }^{476}$ Cf. STJ, $3^{\text {a }}$ T., REsp 537.756/RS, Rel. Min. Carlos Alberto Menezes Direito, j. em 04/11/2003, DJ 10/02/2004 p. 253. V. também TJSP, $3^{\text {a }}$ Câm. de Direito Privado, AC no 586.345-4/3, rel. Des. Beretta da Silveira, j. 09/09/2008

${ }^{477}$ Observer-se que, segundo o art. 124, inc. V, da LPI, é vedado o registro de marcas que reproduza ou imite elemento caracterizador ou diferenciador de nome de empresa de terceiro, suscetível de causar confusão ou associação com estes sinais distintivos.

${ }^{478}$ Como salientou GAMA CERQUEIRA: “[e]ssas questões , como já tivemos ocasião de observar, deviam ser decididas de acordo com os princípios relativos à proteção das marcas, não sendo possível preveni-las ou resolvê-las por meio de regras empíricas e absolutas, que podiam parecer acertadas, mas que, na prática, não surtiam os efeitos esperados, só servindo para criar questões mais complexas. Por outro lado, nem sempre a expressão característica da denominação de uma sociedade prejudicava o titular de marca idêntica ou semelhante, anteriormente registrada, tudo dependendo das circunstâncias de fato, que a lei, por mais casuística que fosse, não podia prever em sua imensa variedade” (op. cit., v. III, p. 314).
} 
respeito à anterioridade, ou seja, prevalece, em regra, o mais antigo ${ }^{479}$, em respeito aos critérios de originalidade e novidade ${ }^{480-481}$, pelo que o exame de eventual colidência não pode ser dirimido exclusivamente com base no critério da anterioridade, subordinando-se, em atenção à interpretação sistemática, aos preceitos legais condizentes à reprodução ou imitação de marcas ${ }^{482}$.

Assim, a proteção ao nome comercial impede o registro posterior, por terceiro, de marca que reproduza ou imite expressão característica de nome comercial ${ }^{483}$, ainda mais quando no mesmo ambiente de mercado ${ }^{484}$. Da mesma forma, registrada a marca não pode outra empresa industrial, comercial ou de serviços utilizá-la, ainda que parcialmente, na composição de seu nome comercial, em havendo similitude de atividades ${ }^{485-486}$. Em outras palavras, o titular de uma marca não pode impedir que outro empresário utilize-a para compor seu nome de empresa, em ramo de atividade distinto. Portanto, por raciocínio integrativo, deve-se levar em consideração o princípio da especialidade, corolário do nosso direito marcário ${ }^{487}$. Logo, é fundamental a determinação dos ramos de atividade das empresas litigantes. Se distintos, de molde a não importar confusão, nada obsta possam conviver concomitantemente no universo mercantil ${ }^{488}$.

\footnotetext{
${ }^{479}$ Cf. STJ, $3^{\text {a }}$ T., REsp 67.173/PE, Rel. Min. Costa Leite, j. em 09.04.1996, DJ 01/07/1996, p. 24048; $3^{\text {a }}$ T., REsp 77549/MG, Rel. Min. Carlos Alberto Menezes Direito, j. em 17/06/1997, DJ 20/10/1997, p. 53052; e $4^{\mathrm{a}}$ T., REsp 30636/SC, Rel. Min. Sálvio de Figueiredo Teixeira, j. em 14/09/1993, DJ 11/10/1993, p. 21323; TJSP, $8^{\text {a }}$ Câm. de Direito Privado, AC no 13.433-4/0, rel. Des. Debatin Cardoso, j. 12/08/1998; TJSP, $9^{\text {a }}$ Câm. de Direito Privado, AC no 160.806-4/1-00, rel. Des. J. Piva Rodrigues, j. 03/07/2007 ${ }^{480}$ Cf. STJ, 4 $4^{a}$ T., REsp 30.636 / SC, Rel. Min. Sálvio de Figueiredo Teixeira, DJ 11.10.1993 p. 21323 ${ }^{481}$ Ressalte-se que não constitui colidência e/ou violação a utilização de nomes comuns ou vulgares. V. TJSP, $3^{\text {a } C a ̂ m}$. de Direito Privado, AC no 586.844-4/0, rel. Des. Beretta da Silveira, j. 30/09/2008 e TJSP, $3^{\text {a }}$ Câm. de Direito Privado, AC no 513.265-4/9, rel. Des. Beretta da Silveira, j. 14/08/2007.

${ }^{482}$ Cf. STJ, $4^{a}$ T., EDcl nos EDcl no AgRg no REsp 653.609/RJ, Rel. Min. Jorge Scartezzini, j. em 19.05.2005, DJ 27.06.2005 p. 408.

${ }^{483}$ Cf. TJSP, $2^{\mathrm{a}}$ Câm. de Direito Privado, AC no 098.154-4/9, rel. Des. J. Roberto Bedran, j. 20/06/2000

${ }^{484}$ Cf. STJ, $3^{\mathrm{a}}$ T., REsp 284.742/SP, Rel. Min. Carlos Alberto Menezes Direito, j. em 20.08.2001, DJ 08.10 .2001 p. 212

${ }^{485}$ Cf. STJ, $4^{\text {a }}$ T., REsp 198.609/ES, Rel. Min. Barros Monteiro, j. em 11.05.2004, DJ 30.08.2004 p. 288

${ }^{486}$ Observe-se que houve julgados em que, de forma salomônica, decidiu-se que havendo colidência entre marca e parte do nome comercial, a fim de garantir a proteção juridica tanto a uma quanto a outro, determinou-se ao proprietario do nome que se abstivesse de utilizar isoladamente a expressão que constituisse a marca registrada pelo terceiro, de propriedade desse, sem prejuizo da utilização do nome empresarial por inteiro, quer nos letreiros, quer no material de propaganda ou documentos e objetos. Nesse sentido, v. o já mencionado REsp 40.190/RJ.

${ }_{487}$ V. PONTES DE MIRANDA, Op. cit., t. XVI, p. 241

${ }^{488}$ Em sentido contrário, vide $4^{\mathrm{a}}$ T., REsp 119.998/SP, Rel. Min. Sálvio de Figueiredo Teixeira, j. em 09.03.1999, DJ 10.05.1999 p. 177, no qual se decidiu que em havendo colidência entre marca e parte do nome comercial, sendo distintas as atividades das duas empresas, a fim de garantir a proteção jurídica tanto a uma quanto a outro, determina-se ao proprietário do nome que se abstenha de utilizar isoladamente a expressão que constitui a marca registrada pelo outro, terceiro, de propriedade desse, sem prejuízo da utilização do seu nome comercial por inteiro.
} 
A nosso ver, também o titular de marca de fato (aquela não registrada) também goza de um direito exclusivo, facultando-lhe a lei todas as ações que faculta ao titular de marca registrada, inclusive no conflito com nomes empresarias ${ }^{489}$.

Decidiu o STJ que "conquanto se objete que tal vedação visa à proteção do nome comercial de per si, o exame de eventual colidência entre marca integrada pelo nome comercial do titular versus marca alheia idêntica ou semelhante posteriormente registrada, não pode ser dirimido apenas com base na anterioridade, subordinando-se, em interpretação sistemática, aos preceitos relativos à reprodução de marcas, consagradores do princípio da especificidade" ${ }^{490}$.

\subsection{Nome empresarial $v s$ título de estabelecimento}

No Cap. II constatamos que o nome empresarial identifica e individualiza o próprio empresário, ao passo que o título de estabelecimento distingue o estabelecimento empresarial. Ao titular do nome empresarial é assegurado o direito de impedir o uso por terceiro de título de estabelecimento que o imite ou reproduza ${ }^{491}$.

No conflito entre nomes empresariais e títulos de estabelecimento devem ser aplicados os mesmos critérios pertinentes ao conflito com marcas, a que nos referimos linhas acima. Destarte, em havendo colidência entre nome empresarial e título de estabelecimento prevalecerá o direito daquele que primeiro adotou o sinal (princípio da anterioridade), em respeito aos critérios de originalidade e novidade, dentro de um mesmo ramo de atividade ${ }^{492}$.

Isso porque, o empresário que adotou, em seu nome empresarial, expressão peculiar, passa, a partir do registro respectivo, a ter legitimidade para adotar referida

\footnotetext{
${ }^{489}$ As marcas de fato, i. e. aqueles não registradas, também têm proteção. De acordo com a lição de DELMANTO: "tanto para a tipificação da hipótese de confusão de produto do concorrente que esta figura abrange, como para outras modalidades de competição delituosa, não há qualquer necessidade de que a marca, nome, insígnia, desenho ou sinal imitados, estejam registrados, ou mesmo sejam registráveis" (in Crimes de concorrência desleal. São Paulo: Butshatski, Ed. da Universidade de São Paulo, 1975, p. 90). No mesmo sentido Newton SILVEIRA: "um elemento provido de eficácia distintiva e não registrado assegura ao seu titular uma tutela contra o perigo de confusão entre produtos ou atividades, tutela que deriva das normas sobre concorrência desleal e não daquelas sobre a marca" (in Licença de uso de marca e outros sinais distintivos, cit., p. 44)

${ }^{490}$ Cf. 4 a T., REsp 658.702/RJ, Rel. Min. Jorge Scartezzini, j. em 29/06/2006, DJ 21/08/2006 p. 254; Vide também os já citados EDcl nos EDcl no AgRg no REsp 653.609/RJ

${ }^{491} \mathrm{Na}$ mesma forma o "[d] c carácter exclusivo do direito ao nome [título de estabelecimento] ou à insígnia decorre que um terceiro não poderá utilizar um sinal idêntico ou semelhante em termos de lesar o correspondente direito, mesmo que esse sinal integre outro tipo de direito de propriedade industrial" (Cf. Olavo, Carlos. Op. cit., p. 187).
} 
expressão também como sinal externo distintivo e característico do estabelecimento empresarial e, assim, impedir que outra empresa que atue no mesmo ramo de atividade como tal a utilize ${ }^{493}$.

\subsection{Nome empresarial vs nome de domínio}

Nome de domínio é "um nome que serve para localizar e identificar conjuntos de computadores na Internet. O nome de domínio foi concebido com o objetivo de facilitar a memorização dos endereços de computadores na Internet ${ }^{494}$. Sem ele, teríamos que memorizar uma sequência grande de números. O nome de domínio para aqueles que não são técnicos na área de informática, nada mais é do que o endereço eletrônico de uma página na Internet. Para que se acesse uma determinada página é necessário digitar seu endereço, o que corresponde ao seu nome de domínio. Exatamente pela sua função de identificação, é que ao nome de domínio não pode ter seu núcleo formado por expressão protegida como marca, sob pena de concorrência desleal prevista no art. 209, da LPI" 495.

Ressalte-se que o art. $1^{\circ}, \S 1^{\circ}$ e $4^{\circ}$, inc. IV, da Resolução $n^{\circ} 2 / 2005$, do Comitê Gestor da Internet no Brasil, vedam o registro de nomes de domínio que induzam terceiros a erro, que viole direitos de terceiros.

Com tanto mais razão, o nome de domínio não pode ser formado por expressão integrante de nome empresarial alheio. Em outras palavras, o arquivamento dos atos constitutivos no registro próprio assegura direito ao uso exclusivo ao nome empresarial, também na Internet, porque a Constituição Federal (art. $5^{\circ}$, XXIX) não faz distinção quanto à área de proteção da propriedade das marcas e nomes das empresas" ${ }^{496}$. A proteção dá-se, inclusive, em se tratando de nome empresarial de empresa estrangeira, conforme já decidiu o TJSP ${ }^{497}$.

${ }^{492}$ Cf. STJ, $4^{\mathrm{a}}$ T., REsp 30.636.3/SC, rel. Min. Sálvio de Figueiredo Teixeira, j. em 14/091993, RSTJ 53/220 (Caso "PÉ QUENTE")

${ }^{493}$ V. STJ, $3^{\mathrm{a}}$ T., REsp 54.494.7/SP, rel. Min. Waldemar Zveiter, j. em 04/04/1995, RSTJ 78/209; TJSP, $8^{\mathrm{a}}$ Câm. de Direito Privado, AC nº 064.633-4/1, rel. Des. Aldo Magalhães, j. 07/04/1999; TJSP, $4^{a}$ Câm. de Direito Privado, AC no 432.763-4/1, rel. Des. J.G. Jacobina Rabello, j. 23/02/2006

${ }^{494}$ Observe-se que os computadores ligados à rede mundial (Internet) são identificados por um código numérico denominado Internet Protocol (IP), cuja memorização é facilitada por um sistema de nomes Domain Name System (DNS) - que são conhecidos como nomes de domínio.

${ }^{495}$ CoElHo, Fábio Ulhoa. Curso de Direito Comercial, vol. 3. São Paulo: Saraiva, 2005, p. 37

${ }^{496}$ TJSP, $4^{\text {a }}$ Câm. de Direito Privado, AC no 127.773-4/8-00, rel. Des. Carlos Stroppa, j. 13/06/2002.

${ }^{497}$ Cf. TJSP, $4^{a}$ Câm. de Direito Privado, AC no 324.341-4/3, rel. Des. Teixeira Leite, j. 24/07/2008 (Caso "DELL") 
Quando a expressão caracterizadora do nome de domínio coincide com a expressão objeto de nome comercial, de empresário concorrente ou com atividades empresariais similares, está caracterizada a concorrência desleal aberta para desvio de cliente, devendo-se cancelar ou adjudicar o registro junto à FAPESP ${ }^{498-499}$. É dizer: o nome de domínio como espécie de sinal distintivo (marca, nome de empresa ou título de estabelecimento) tem proteção da LPI, de modo que o uso indevido na Internet de nome alheio configura ato de concorrência desleal ${ }^{500}$.

Temos, então, que no conflito entre nomes empresariais e nomes de domínio devese verificar casuisticamente: (a) a anterioridade do uso do sinal ${ }^{501}$; (b) a legitimidade para o uso e registro do domínio, que, normalmente, está relacionada ao próprio uso anterior; e (c) os ramos de atividade ${ }^{502}$.

\footnotetext{
${ }^{498}$ TJSP, 4 a Câm. de Direito Privado, AC no 445.448-4/4-00, rel. Des. Enio Zuliani, j. 18/05/2006.

${ }^{499}$ V. também: TJSP, $8^{a}$ Câm. Cível, AC no $358.728-4 / 3$, rel. Des. Salles Rossi, j. 07/12/2006; TJSP, $10^{\text {a }}$ Câm. de Direito Privado, AI no 196.454-4/2-00, rel. Des. Quaglia Barbosa, j. 26/06/2001; TJRS, $14^{\text {a }}$ Câm. de Direito Privado, AC no 70003100609, rel. Des. Aymoré Roque Pottes de Mello, j. 29/05/2002 ${ }^{500}$ Cf. TJSP, $4^{\mathrm{a}}$ Câm. de Direito Privado, AC n ${ }^{\circ}$ 531.279.4/4, rel. Des. Francisco Loureiro, j. 13/11/2008 ${ }^{501}$ Os direitos emergentes do nome comercial devem ser sempre considerados preponderantes sobre os registros de domínio na internet, representando, esse, por meio dissimulado do uso de designação semelhante, suscetível de causar confusão no público em geral. Nesse sentido v. TJSP, $2^{\mathrm{a}}$ Câm. de Direito Privado, AI n ${ }^{\circ}$ 202.504-4/8, rel. Des. Paulo Hungria, j. 26/06/2001; TJSP, $2^{\text {a }}$ Câm. de Direito Privado, AI n ${ }^{\circ} 312.693-4 / 6$, rel. Des. J. Roberto Bedran, j. 07/10/2003; TJSP, $2^{\text {a }}$ Câm. de Direito Privado, AI n ${ }^{\circ}$ 451.734-4/9, rel. Des. J. Roberto Bedran, j. 23/05/2006; TJSP, $2^{\text {a }}$ Câm. de Direito Privado, AI n 430.852-4/3, rel. Des. Ary José Bauer Júnior, j. 06/02/2007

${ }_{502}$ TJSP, $5^{\text {a }}$ Câm. de Direito Privado, AC no 429.087-4/9, rel. Des. Encinas Manfré, j. 07/02/2007 e TJSP, $5^{\text {a }}$ Câm. de Direito Privado, AC no 281.14 9-4/5, rel. Des. A.C. Mathias Coltro, j. 30/05/2007
} 


\section{CONCLUSÕES}

Vimos, ao longo deste trabalho, que a pessoa considerada em si mesma e em suas projeções na sociedade possui direitos inatos, previstos e protegidos pelo ordenamento jurídico. São os denominados direitos da personalidade, dentre os quais se destaca o direito ao nome, tendo este a função de individualizar a pessoa tanto no plano pessoal, quanto no plano empresarial.

Sempre que o nome do indivíduo for adotado para o fim de exercício de indústria ou de comércio, ele assume a veste jurídica de nome comercial, passando a constituir importante sinal distintivo do empresário.

Verificamos que as expressões nome comercial, nome de empresa e nome empresarial não são sinônimas. O nome comercial sempre esteve ligado à atividade comercial, de modo que a substituição da expressão nome comercial por nome de empresa representa muito mais que mera alteração adjetiva, traduzindo-se em um verdadeiro alargamento de significância e incidência, considerando a adoção da teoria da empresa. É dizer, nome de empresa não é mero sinônimo de nome comercial.

Portanto, nome comercial e nome empresarial têm significados diferentes, mas englobados dentre de um conceito maior de nome de empresa. O primeiro (nome comercial) está ligado à função objetiva do nome (função econômico-concorrencial), como elemento que caracteriza, individualiza e distingue a atividade do empresário, pessoa física ou jurídica, no campo da concorrência. Por seu turno, o segundo (nome empresarial) reflete a função subjetiva do nome (função identificadora), pois tem o encargo apenas de designar o sujeito de direitos e obrigações. Desta forma, podemos dizer que a adoção do nome comercial é facultativa, ao passo que o nome empresarial é uma obrigação do empresário e sociedade empresária.

Destarte, nome de empresa é a firma ou a denominação adotada pelo empresário, pessoa física ou jurídica, para sua identificação no exercício de sua atividade, podendo ser usada como elemento individualizador da empresa em âmbito concorrencial, servindo de instrumento de união entre o empresário e a clientela.

$\mathrm{O}$ nome de empresa exerce, portanto, dupla função. Em um primeiro momento o nome empresarial exerce uma função identificadora, constituindo um sinal de identificação do empresário, como sujeito de direito e obrigações dentro da generalidade dos atos inerentes à sua atividade. De outro lado, exerce uma função econômico-concorrrencial, 
distinguindo seu titular de seus concorrentes no âmbito das atividades econômicas, ou seja, no campo da concorrência.

Assim como ocorre em relação às pessoas naturais, também às pessoas jurídicas é assegurado direito ao nome, como um atributo de sua personalidade jurídica, a partir de seu nascimento, que se dá com a inscrição do ato constitutivo no respectivo registro, precedida, quando necessário, de autorização ou aprovação do Poder Executivo.

Logo, temos que o nome empresarial é um direito de personalidade do empresário ou sociedade empresária, que pode ser definido como sendo a firma ou a denominação adotada pela pessoa física ou jurídica para exercício de sua atividade empresarial.

O nome empresarial é gênero do qual são espécies a firma e a denominação. A firma é o nome, necessariamente correspondente ao nome civil completo ou abreviado, utilizado pelo empresário individual, pela sociedade em que houver sócio de responsabilidade ilimitada (como as sociedades em nome coletivo, as sociedades em comandita simples e as sociedades em comandita por ações) e, de forma facultativa, pela sociedade limitada.

Por seu turno, denominação é todo o nome ou locução aleatória apropriada pelo empresário para sua designação. A denominação tanto pode ser constituída do próprio nome do empresário, como de outro nome arbitrário ou de fantasia, sendo utilizada pela sociedade anônima e cooperativa e, em caráter opcional, pela sociedade limitada e em comandita por ações. Usualmente, é formada com palavras de uso comum ou vulgar na língua nacional ou estrangeira e/ou com expressões de fantasia, com a indicação do objeto da sociedade.

Concluímos que devem ser diferentes os critérios de colidência entre as diversas modalidades de nome empresarial, isto é, vislumbrando que o conflito pode dar-se entre firmas, entre firmas e denominações ou entre denominações.

Uma vez que constitui direito do empresário exercer suas atividades com seu nome civil, a confrontação entre as firmas deve ser feita considerando os nomes como um todo. Em havendo colidência entre firmas individuais, devem-se agregar ao seu nome outros elementos (designação mais precisa da pessoa e/ou gênero de atividade) que o distinga. $\mathrm{O}$ mesmo ocorre em relação à homonímia entre firmas ou razões sociais, em que se deve acrescer designação distintiva.

$\mathrm{O}$ tratamento dado às denominações sociais é diferente. A denominação social, ao contrário das firmas, pode ser constituída arbitrariamente, de modo que o grau de similaridade tolerado é menor. Evidentemente, se pode o empresário escolher livremente o 
nome de fantasia que comporá sua denominação social, esta deve ser necessariamente distinta em relação às demais. Desta forma, se a denominação é formada por expressões de uso comum, vulgar ou meramente descritiva, a colidência deve ser feita considerando o nome como um todo. Por outro lado, se composta por expressão característica incomum e distintiva, a análise de colidência das denominações deve considerar tais expressões isoladamente.

A dicotomia entre as funções exercidas pelo nome de empresa também se verifica no campo legislativo, visto que enquanto nome comercial (função econômicoconcorrencial), usado como cordão umbilical entre a clientela e o empresário, sua tutela dá-se, atualmente, pela Constituição Federal de 1988, pela Lei da Propriedade Industrial, pela Convenção da União de Paris e pelo Código de Defesa do Consumidor. Já o nome empresarial, como sinal identificador do empresário ou sociedade empresária (função subjetiva) é regido pela Lei de Registro Público de Empresas Mercantis e pelo Código Civil.

Desta forma, exercendo sua função identificadora, que decorre da personalidade do empresário, o nome empresarial deveria ter proteção absoluta, ou seja, independente de qualquer limite territorial ou ramo de atividade, atuando o fator concorrência apenas como agravante.

Não obstante, o CC, equivocadamente, impõe ao nome empresarial proteção adstrita à circunscrição da Junta Comercial onde foram arquivados os atos constitutivos ou alterações ou à comarca na qual se localize o Registro Público de Pessoas Jurídicas. Tal limitação, antes prevista apenas no Decreto $n^{\circ} 1.800 / 1996$, era destinada exclusivamente às Juntas Comerciais. Assim, clama por reforma o malsinado art. 1.166, do CC.

De outra banda, o nome comercial, em sua função econômico-concorrencial, tem sua proteção estendida para todo o território em que haja potencial concorrência, não havendo, destarte, limitação territorial preestabelecida, cabendo ao juiz, no caso concreto, aferir a presença da relação de concorrência. Esta relação concorrencial, ao passo que fixa o âmbito territorial de proteção, delimita a extensão da proteção à atividade desenvolvida, ou seja, a proteção é assegurada apenas no mesmo ramo de atividade ou afins.

Em conclusão, para avaliar a possibilidade de confusão entre os nomes comerciais, deve-se ter em consideração sua identidade ou semelhança, assim como o âmbito de territorial estabelecido por uma relação de concorrência. Nesta análise objetiva de confusão, deve-se ter em mente o público médio, vislumbrando potencial confusão, não sendo exigida confusão efetiva. 
O titular de nome de empresa, como visto, tem proteção assegurada contra a adoção de nomes idênticos ou similares adotados por terceiro, independentemente de qualquer registro ou formalidade. Como corolário deste direito, o empresário tem remédios jurídicos para agir contra usurpadores, de modo a elidir o uso indevido, pleitear a modificação do nome de empresa pelo terceiro e, ainda, auferir valores devidos em razão dos prejuízos que lhe foram causados.

Poderá o titular do nome empresarial apresentar recurso administrativo, dirigido ao plenário da Junta Comercial, no qual deverá demonstrar o conflito entre seu nome e o nome posteriormente adotado por terceiro, não sendo possível alegar violação de outros sinais distintivos, tais como: marcas, títulos de estabelecimento e insígnia.

Na esfera cível, são três as principais ações de que pode se valer o titular do nome empresarial para sua proteção, notadamente a ação de abstenção de uso, ação de modificação de nome e, finalmente, ação indenizatória.

Para a tutela do nome comercial, há, ainda, a ação penal privada com fulcro no crime de concorrência desleal, tipificado no art. 195, V, da LPI. 


\section{APÊNDICE LEGISLATIVO}

\section{CONSTITUIÇÃO DA REPÚBLICA FEDERATIVA DO BRASIL DE 1988}

Art. $5^{\circ}$ Todos são iguais perante a lei, sem distinção de qualquer natureza, garantindo-se aos brasileiros e aos estrangeiros residentes no País a inviolabilidade do direito à vida, à liberdade, à igualdade, à segurança e à propriedade, nos termos seguintes:

XXIX - a lei assegurará aos autores de inventos industriais privilégio temporário para sua utilização, bem como proteção às criações industriais, à propriedade das marcas, aos nomes de empresas e a outros signos distintivos, tendo em vista o interesse social e o desenvolvimento tecnológico e econômico do País; 


\section{CONVENÇÃO DA UNIÃO DE PARIS \\ ESTOCOLMO (1967) \\ DECRETO N. 75.572 de 8 de abril de 1975}

\section{Art. 1}

(1) Os países a que se aplica a presente Convenção constituem-se em União para a proteção da propriedade industrial.

(2) A proteção da propriedade industrial tem por objeto as patentes de invenção, os modelos de utilidade, os desenhos ou modelos industriais, as marcas de serviço, o nome comercial e as indicações de procedência ou denominações de origem, bem como a repressão da concorrência desleal.

Art. 8

O nome comercial será protegido em todos os países da União sem obrigações de depósito ou de registro, quer faça ou não parte de uma marca de fábrica ou de comércio. 


\section{LEI No 10.406, DE 10 DE JANEIRO DE 2002. (CÓDIGO CIVIL BRASILEIRO)}

Art. 1.155. Considera-se nome empresarial a firma ou a denominação adotada, de conformidade com este Capítulo, para o exercício de empresa.

Parágrafo único. Equipara-se ao nome empresarial, para os efeitos da proteção da lei, a denominação das sociedades simples, associações e fundações.

Art. 1.156. O empresário opera sob firma constituída por seu nome, completo ou abreviado, aditando-lhe, se quiser, designação mais precisa da sua pessoa ou do gênero de atividade.

Art. 1.157. A sociedade em que houver sócios de responsabilidade ilimitada operará sob firma, na qual somente os nomes daqueles poderão figurar, bastando para formá-la aditar ao nome de um deles a expressão "e companhia" ou sua abreviatura.

Parágrafo único. Ficam solidária e ilimitadamente responsáveis pelas obrigações contraídas sob a firma social aqueles que, por seus nomes, figurarem na firma da sociedade de que trata este artigo.

Art. 1.158. Pode a sociedade limitada adotar firma ou denominação, integradas pela palavra final "limitada" ou a sua abreviatura.

§ 1o A firma será composta com o nome de um ou mais sócios, desde que pessoas físicas, de modo indicativo da relação social.

$\S 20$ A denominação deve designar o objeto da sociedade, sendo permitido nela figurar o nome de um ou mais sócios.

§ 3o A omissão da palavra "limitada" determina a responsabilidade solidária e ilimitada dos administradores que assim empregarem a firma ou a denominação da sociedade. 
Art. 1.159. A sociedade cooperativa funciona sob denominação integrada pelo vocábulo "cooperativa".

Art. 1.160. A sociedade anônima opera sob denominação designativa do objeto social, integrada pelas expressões "sociedade anônima" ou "companhia", por extenso ou abreviadamente.

Parágrafo único. Pode constar da denominação o nome do fundador, acionista, ou pessoa que haja concorrido para o bom êxito da formação da empresa.

Art. 1.161. A sociedade em comandita por ações pode, em lugar de firma, adotar denominação designativa do objeto social, aditada da expressão "comandita por ações".

Art. 1.162. A sociedade em conta de participação não pode ter firma ou denominação.

Art. 1.163. O nome de empresário deve distinguir-se de qualquer outro já inscrito no mesmo registro.

Parágrafo único. Se o empresário tiver nome idêntico ao de outros já inscritos, deverá acrescentar designação que o distinga.

Art. 1.164. O nome empresarial não pode ser objeto de alienação.

Parágrafo único. O adquirente de estabelecimento, por ato entre vivos, pode, se o contrato o permitir, usar o nome do alienante, precedido do seu próprio, com a qualificação de sucessor.

Art. 1.165. O nome de sócio que vier a falecer, for excluído ou se retirar, não pode ser conservado na firma social.

Art. 1.166. A inscrição do empresário, ou dos atos constitutivos das pessoas jurídicas, ou as respectivas averbações, no registro próprio, asseguram o uso exclusivo do nome nos limites do respectivo Estado. 
Parágrafo único. O uso previsto neste artigo estender-se-á a todo o território nacional, se registrado na forma da lei especial.

Art. 1.167. Cabe ao prejudicado, a qualquer tempo, ação para anular a inscrição do nome empresarial feita com violação da lei ou do contrato.

Art. 1.168. A inscrição do nome empresarial será cancelada, a requerimento de qualquer interessado, quando cessar o exercício da atividade para que foi adotado, ou quando ultimar-se a liquidação da sociedade que o inscreveu. 


\section{LEI N' 9.279, DE 14 DE MAIO DE 1996. \\ (LEI DA PROPRIEDADE INDUSTRIAL)}

Art. 2o.- A proteção dos direitos relativos à propriedade industrial, considerado o seu interesse social e o desenvolvimento tecnológico e econômico do País, efetua-se mediante:

V - repressão à concorrência desleal.

Art. 124. Não são registráveis como marca:

V - reprodução ou imitação de elemento característico ou diferenciador de título de estabelecimento ou nome de empresa de terceiros, suscetível de causar confusão ou associação com estes sinais distintivos;

Art. 191. Reproduzir ou imitar, de modo que possa induzir em erro ou confusão, armas, brasões ou distintivos oficiais nacionais, estrangeiros ou internacionais, sem a necessária autorização, no todo ou em parte, em marca, título de estabelecimento, nome comercial, insígnia ou sinal de propaganda, ou usar essas reproduções ou imitações com fins econômicos.

Pena - detenção, de 1 (um) a 3 (três) meses, ou multa.

Art. 195. Comete crime de concorrência desleal quem:

$\mathrm{V}$ - usa, indevidamente, nome comercial, título de estabelecimento ou insígnia alheios ou vende, expõe ou oferece à venda ou tem em estoque produto com essas referências;

Pena - detenção, de 3 (três) meses a 1 (um) ano, ou multa. 


\section{LEI No 8.934, DE 18 DE NOVEMBRO DE 1994.}

Art. 33. A proteção ao nome empresarial decorre automaticamente do arquivamento dos atos constitutivos de firma individual e de sociedades, ou de suas alterações.

$\S 1^{\mathrm{o}}$ (Vetado).

$\S 2^{\circ}$ (Vetado).

Art. 34. O nome empresarial obedecerá aos princípios da veracidade e da novidade.

Art. 35. Não podem ser arquivados:

III - os atos constitutivos de empresas mercantis que, além das cláusulas exigidas em lei, não designarem o respectivo capital, bem como a declaração precisa de seu objeto, cuja indicação no nome empresarial é facultativa;

V - os atos de empresas mercantis com nome idêntico ou semelhante a outro já existente; 


\section{DECRETO N 1.800, DE 30 DE JANEIRO DE 1996.}

Art. 48. A empresa mercantil que não proceder a qualquer arquivamento no período de dez anos, contados da data do último arquivamento, deverá comunicar à Junta Comercial que deseja manter-se em funcionamento, sob pena de ser considerada inativa, ter seu registro cancelado e perder, automaticamente, a proteção de seu nome empresarial.

$\S 1^{\circ}$ A empresa mercantil deverá ser notificada previamente pela Junta Comercial, mediante comunicação direta ou por edital, para os fins deste artigo.

$\S 2^{\circ}$ A comunicação de que trata o caput deste artigo, quando não tiver ocorrido modificação de dados no período, será efetuada em formulário próprio, assinada, conforme o caso, pelo titular, sócios ou representante legal, e, na hipótese de ter ocorrido modificação nos dados, a empresa deverá arquivar a competente alteração.

Art. 53. Não podem ser arquivados:

III - os atos constitutivos e os de transformação de sociedades mercantis, se deles não constarem os seguintes requisitos, além de outros exigidos em lei:

a) o tipo de sociedade mercantil adotado;

e) o nome empresarial, o município da sede, com endereço completo, e foro, bem como os endereços completos das filiais declaradas;

Art. 61. A proteção ao nome empresarial, a cargo das Juntas Comerciais, decorre, automaticamente, do arquivamento da declaração de firma mercantil individual, do ato constitutivo de sociedade mercantil ou de alterações desses atos que impliquem mudança de nome.

$\S 1^{\circ}$ A proteção ao nome empresarial circunscreve-se à unidade federativa de jurisdição da Junta Comercial que procedeu ao arquivamento de que trata o caput deste artigo. 
$\S 2^{\circ}$ A proteção ao nome empresarial poderá ser estendida a outras unidades da federação, a requerimento da empresa interessada, observada instrução normativa do Departamento Nacional de Registro do Comércio - DNRC.

$\S 3^{\circ}$ Expirado o prazo da sociedade celebrada por tempo determinado, esta perderá a proteção do seu nome empresarial.

Art. 62. O nome empresarial atenderá aos princípios da veracidade e da novidade e identificará, quando assim o exigir a lei, o tipo jurídico da sociedade.

$\S 1^{\circ}$ Havendo indicação de atividades econômicas no nome empresarial, essas deverão estar contidas no objeto da firma mercantil individual ou sociedade mercantil.

$\S 2^{\circ}$ Não poderá haver colidência por identidade ou semelhança do nome empresarial com outro já protegido.

$\S 3^{\circ}$ O Departamento Nacional de Registro do Comércio - DNRC, através de instruções normativas, disciplinará a composição do nome empresarial e estabelecera critérios para verificação da existência de identidade ou semelhança entre nomes empresariais. 


\title{
INSTRUÇÃO NORMATIVA N 104, 30 DE ABRIL DE 2007.
}

Dispõe sobre a formação de nome empresarial, sua proteção e dá outras providências.

\begin{abstract}
O DIRETOR DO DEPARTAMENTO NACIONAL DE REGISTRO DO COMÉRCIO - DNRC , no uso das atribuições que lhe confere o artigo $4^{\circ}$ da Lei $n^{\circ} 8.934$, de 18 de novembro de 1994, o art. 61, $\S 2^{\circ}$ e art. 62, $\S 3^{\circ}$ do Decreto $n^{\circ} 1.800$, de 30 de janeiro de 1996; e
\end{abstract}

CONSIDERANDO as disposições contidas no art. $5^{\circ}$, inciso XXIX, da Constituição Federal; nos arts. 33, 34 e 35, incisos III e V, da Lei no 8.934, de 18 de novembro de 1994; nos arts. $3^{\circ}, 267$ e 271 da Lei no 6.404, de 15 de dezembro de 1976; na Lei $\mathrm{n}^{\circ}$ 10.406, de 10 de janeiro de 2002; na Lei $\mathrm{n}^{\circ} 11.101$, de 9 de fevereiro de 2005; no Decreto $n^{\circ} 619$, de 29 de julho de 1992; e

CONSIDERANDO as simplificações e desburocratização dos referenciais para a análise dos atos apresentados ao Registro Público de Empresas Mercantis e Atividades Afins, no que se refere ao nome empresarial, introduzidas pelo art. 72 da Lei Complementar $\mathrm{n}^{\circ} 123$, de 14 de dezembro de 2006, resolve:

Art. $1^{\circ}$ Nome empresarial é aquele sob o qual o empresário e a sociedade empresária exercem suas atividades e se obrigam nos atos a elas pertinentes.

Parágrafo único. O nome empresarial compreende a firma e a denominação.

Art. $2^{\circ}$ Firma é o nome utilizado pelo empresário, pela sociedade em que houver sócio de responsabilidade ilimitada e, de forma facultativa, pela sociedade limitada.

Art. $3^{\circ}$ Denominação é o nome utilizado pela sociedade anônima e cooperativa e, em caráter opcional, pela sociedade limitada e em comandita por ações.

Art. $4^{\circ} \mathrm{O}$ nome empresarial atenderá aos princípios da veracidade e da novidade e identificará, quando assim exigir a lei, o tipo jurídico da sociedade. 
Parágrafo único. O nome empresarial não poderá conter palavras ou expressões que sejam

atentatórias à moral e aos bons costumes.

Art. $5^{\circ}$ Observado o princípio da veracidade:

I - o empresário só poderá adotar como firma o seu próprio nome, aditando, se quiser ou quando já existir nome empresarial idêntico, designação mais precisa de sua pessoa ou de sua atividade;

II - a firma:

a) da sociedade em nome coletivo, se não individualizar todos os sócios, deverá conter o nome de pelo menos um deles, acrescido do aditivo "e companhia", por extenso ou abreviado;

b) da sociedade em comandita simples deverá conter o nome de pelo menos um dos sócios comanditados, com o aditivo "e companhia", por extenso ou abreviado;

c) da sociedade em comandita por ações só poderá conter o nome de um ou mais sócios diretores ou gerentes, com o aditivo "e companhia", por extenso ou abreviado, acrescida da expressão “comandita por ações”, por extenso ou abreviada;

d) da sociedade limitada, se não individualizar todos os sócios, deverá conter o nome de pelo menos um deles, acrescido do aditivo "e companhia" e da palavra "limitada", por extenso ou abreviados;

III - a denominação é formada com palavras de uso comum ou vulgar na língua nacional ou estrangeira e ou com expressões de fantasia, com a indicação do objeto da sociedade, sendo que:

a) na sociedade limitada, deverá ser seguida da palavra "limitada", por extenso ou abreviada;

b) na sociedade anônima, deverá ser acompanhada da expressão "companhia" ou "sociedade anônima", por extenso ou abreviada, vedada a utilização da primeira ao final;

c) na sociedade em comandita por ações, deverá ser seguida da expressão "em comandita por ações", por extenso ou abreviada; 
d) para as sociedades enquadradas como microempresa ou empresa de pequeno porte, inclusive quando o enquadramento se der juntamente com a constituição, é facultativa a inclusão do objeto da sociedade;

e) ocorrendo o desenquadramento da sociedade da condição de microempresa ou empresa de pequeno porte, é obrigatória a inclusão do objeto da sociedade empresária no nome empresarial, mediante arquivamento da correspondente alteração contratual.

$\S 1^{\circ} \mathrm{Na}$ firma, observar-se-á, ainda:

a) o nome do empresário deverá figurar de forma completa, podendo ser abreviados os prenomes;

b) os nomes dos sócios poderão figurar de forma completa ou abreviada, admitida a supressão de prenomes;

c) o aditivo "e companhia" ou "\& Cia.” poderá ser substituído por expressão equivalente, tal como "e filhos" ou "e irmãos", dentre outras.

$\S 2^{\circ} \mathrm{O}$ nome empresarial não poderá conter palavras ou expressões que denotem atividade não prevista no objeto da sociedade.

Art. $6^{\circ}$ Observado o princípio da novidade, não poderão coexistir, na mesma unidade federativa, dois nomes empresariais idênticos ou semelhantes.

$\S 1^{\circ}$ Se a firma ou denominação for idêntica ou semelhante a de outra empresa já registrada, deverá ser modificada ou acrescida de designação que a distinga.

$\S 2^{\circ}$ Será admitido o uso da expressão de fantasia incomum, desde que expressamente autorizada pelos sócios da sociedade anteriormente registrada.

Art. $7^{\circ}$ Não são registráveis os nomes empresariais que incluam ou reproduzam, em sua composição, siglas ou denominações de órgãos públicos da administração direta ou indireta e de organismos nacionais e internacionais.

Art. $8^{\circ}$ Ficam estabelecidos os seguintes critérios para a análise de identidade e semelhança dos nomes empresariais, pelos órgãos integrantes do Sistema Nacional de Registro de Empresas Mercantis - SINREM: 
I - entre firmas, consideram-se os nomes por inteiro, havendo identidade se homógrafos e semelhança se homófonos;

II - entre denominações:

a) consideram-se os nomes por inteiro, quando compostos por expressões comuns, de fantasia, de uso generalizado ou vulgar, ocorrendo identidade se homógrafos e semelhança se homófonos;

b) quando contiverem expressões de fantasia incomuns, serão elas analisadas isoladamente, ocorrendo identidade se homógrafas e semelhança se homófonas.

Art. $9^{\circ}$ Não são exclusivas, para fins de proteção, palavras ou expressões que denotem:

a) denominações genéricas de atividades;

b) gênero, espécie, natureza, lugar ou procedência;

c) termos técnicos, científicos, literários e artísticos do vernáculo nacional ou estrangeiro, assim como quaisquer outros de uso comum ou vulgar;

d) nomes civis.

Parágrafo único. Não são suscetíveis de exclusividade letras ou conjunto de letras, desde que não configurem siglas.

Art. 10. No caso de transferência de sede ou de abertura de filial de empresa com sede em outra unidade federativa, havendo identidade ou semelhança entre nomes empresariais, a Junta Comercial não procederá ao arquivamento do ato, salvo se:

I - na transferência de sede a empresa arquivar na Junta Comercial da unidade federativa de destino, concomitantemente, ato de modificação de seu nome empresarial;

II - na abertura de filial arquivar, concomitantemente, alteração de mudança do nome empresarial, arquivada na Junta Comercial da unidade federativa onde estiver localizada a sede. 
Art. 11. A proteção ao nome empresarial decorre, automaticamente, do ato de inscrição de empresário ou do arquivamento de ato constitutivo de sociedade empresária, bem como de sua alteração nesse sentido, e circunscreve-se à unidade federativa de jurisdição da Junta Comercial que o tiver procedido.

$\S 1^{\mathrm{o}}$ A proteção ao nome empresarial na jurisdição de outra Junta Comercial decorre, automaticamente, da abertura de filial nela registrada ou do arquivamento de pedido específico, instruído com certidão da Junta Comercial da unidade federativa onde se localiza a sede da sociedade interessada.

$\S 2^{\circ}$ Arquivado o pedido de proteção ao nome empresarial, deverá ser expedida comunicação do fato à Junta Comercial da unidade federativa onde estiver localizada a sede da empresa.

Art. 12. O empresário poderá modificar a sua firma, devendo ser observadas em sua composição, as regras desta Instrução.

$\S 1^{\circ}$ Havendo modificação do nome civil de empresário, averbada no competente Registro Civil das Pessoas Naturais, deverá ser arquivada alteração com a nova qualificação do empresário, devendo ser, também, modificado o nome empresarial.

$\S 2^{\circ}$ Se a designação diferenciadora se referir à atividade, havendo mudança, deverá ser registrada a alteração da firma.

Art. 13. A expressão "grupo" é de uso exclusivo dos grupos de sociedades organizados, mediante convenção, na forma da Lei das Sociedades Anônimas.

Parágrafo único. Após o arquivamento da convenção do grupo, a sociedade de comando e as filiadas deverão acrescentar aos seus nomes a designação do grupo.

Art. 14. As microempresas e empresas de pequeno porte acrescentarão à sua firma ou denominação as expressões "Microempresa" ou "Empresa de Pequeno Porte", ou suas respectivas abreviações, "ME" ou "EPP". 
Art. 15. Aos nomes das Empresas Binacionais Brasileiro-Argentinas deverão ser aditadas "Empresa Binacional Brasileiro-Argentinas", "EBBA" ou "EBAB" e as sociedades estrangeiras autorizadas a funcionar no Brasil poderão acrescentar os termos “do Brasil” ou "para o Brasil" aos seus nomes de origem.

Art. 16. Ao final dos nomes dos empresários e das sociedades empresárias que estiverem em processo de liquidação, após a anotação no Registro de Empresas, deverá ser aditado o termo "em liquidação".

Art. 17. Nos casos de recuperação judicial, após a anotação no Registro de Empresas, o empresário e a sociedade empresária deverão acrescentar após o seu nome empresarial a expressão "em recuperação judicial”, que será excluída após comunicação judicial sobre a sua recuperação.

Art. 18. Esta Instrução entra em vigor na data de sua publicação.

Art. 19. Fica revogada a Instrução Normativa $N^{\circ}$ 99, de 21 de dezembro de 2005. 


\section{LEI No 8.078, DE 11 DE SETEMBRO DE 1990. (CÓDIGO DE DEFESA DO CONSUMIDOR)}

Art. $4^{\circ}$ A Política Nacional das Relações de Consumo tem por objetivo o atendimento das necessidades dos consumidores, o respeito à sua dignidade, saúde e segurança, a proteção de seus interesses econômicos, a melhoria da sua qualidade de vida, bem como a transparência e harmonia das relações de consumo, atendidos os seguintes princípios:

VI - coibição e repressão eficientes de todos os abusos praticados no mercado de consumo, inclusive a concorrência desleal e utilização indevida de inventos e criações industriais das marcas e nomes comerciais e signos distintivos, que possam causar prejuízos aos consumidores; 


\section{BIBLIOGRAFIA}

Aввотt, Frederick, CotTIER, Thomas e GURRY, Francis. The International Intellectual Property System: commentary and materials. The Hague: Kluwer Law International, 1999

AdEnsohn De SouZA, Daniel. Introdução do direito de empresas no novo Código Civil. A unificação do direito das obrigações, Revista de Direito Empresarial nº 9, jan./jun. 2008, Curitiba: Juruá, 2008 A propriedade industrial e o direito concorrencial: a questão da proteção aos desenhos industriais no mercado de reposição. Revista da Associação Brasileira da Propriedade Intelectual, $n^{\circ}$ 96, set./out. 2008

Almeida Nogueira, J. L. de \& FISHER JÚNIOR, Guilherme. Tratado theórico e prático de marcas industriaes e nome commercial. São Paulo, Typ. Hennies Irmãos, 1910.

ARRudA, Mauro J. G. Considerações sobre a proteção jurídica do nome comercial, em face do projeto do novo Código Civil, Revista de Direito Mercantil, Industrial, Econômico e Financeiro, $\mathrm{n}^{\mathrm{o}}$ 113, jan./mar. 1.999

ASCARELl, Tullio. Teoría de la concurrencia y de los bienes inmateriales. Barcelona, Bosch, 1970.

ASQUINI, Alberto. Perfis da empresa (Profili dell'impresa. Rivista del Diritto Commerciale 41, I. 1943). Trad. De Fábio Konder Comparato. Revista de Direito Mercantil, Industrial, Econômico e Financeiro, v. 35, n. 104, p. 109-126, out./dez. 1996

Assis, Araken de. Cumprimento da sentença, Rio de Janeiro: Forense, 2.006

Auger, Albert. Dés Brevets D’Invéntion, des Marques de Fabrique \& de Commerce et du Nom Commercial. Paris: L. Larose \& Forcel, 1882

BARBoSA, Denis Borges. Uma introdução à propriedade intelectual, $2^{\mathrm{a}}$ ed. rev. e atual. Rio de Janeiro: Lumen Juris, 2003. 
BARreto Filho, Oscar. Teoria do estabelecimento comercial. São Paulo: Max Limonad, 1969.

BASSO, Maristela. O direito internacional da propriedade intelectual. Porto Alegre: Livraria do Advogado, 2000.

Bento DE FARIA, Antonio. Das marcas de fabrica e de commercio e do nome commercial. Rio de Janeiro: J. Ribeiro dos Santos, 1906.

BERMUDES, Sérgio. A tutela cautelar na propriedade industrial. Anais do VI Seminário Nacional da Propriedade Industrial da Associação Brasileira da Propriedade Intelectual, Rio de Janeiro: 1986

BITTAR, Carlos Alberto. Os direitos da personalidade, $1^{\mathrm{a}}$ ed., Rio de Janeiro: Forense Universitária, 1989 . Teoria e prática da concorrência desleal. São Paulo: Saraiva, 1989. . Reparação civil por danos morais, $2^{\mathrm{a}}$ ed. São Paulo: Revista dos Tribunais, 1993

Bodenhausen, Georg Hendrik Christiaan. Guide to the application of the Paris Convention for the protection of industrial property, as revised at Stockholm in 1967, Geneva: [Colombettes 32,] United International Bureaux for the Protection of Intellectual Property, 1968.

BONASI BENUCCI, Eduardo. Tutela della forma nel diritto industriale. Milano, A. Giuffrè, 1963.

BrebBiA, Roberto H. El daño moral, 2a ed., B. Aires, Orbir, 1967.

Bulgarelli, Waldírio. Contratos mercantis. São Paulo: Atlas, 1979.

CaIru, José da Silva Lisboa, Visconde de. Princípios de direito mercantil e leis de marinha, $6^{a}$ ed. Rio de Janeiro: Typographia Acadêmica, 1874. 
CAMEliER Da Silva, Alberto Luís. Concorrência desleal: atos de confusão. (Dissertação de Mestrado em Direito), São Paulo: FADUSP, 2007.

CAmpilongo, Celso Fernandes. Política, sistema jurídico e decisão judicial, São Paulo: Max Limonad, 2002

CAnotilho, José Joaquim Gomes. Direito constitucional e teoria da constituição, $4^{\mathrm{a}}$ ed. Coimbra: Livraria Almedina, 2000

CARnelutti, Francesco. Usucapión de la propiedad industrial. México, Porrúa, 1945.

Celso, Affonso. Marcas industriaes e nome commercial. Rio de Janeiro, B. L. Garnier, 1888.

Coelho, Fabio Ulhoa. Manual de Direito Comercial, 16 ed., São Paulo: Saraiva, 2005. Curso de Direito Comercial, vol. 3. São Paulo: Saraiva, 2005

Comparato, Fabio Konder. Aspectos jurídicos da macro-empresa, São Paulo: Revista dos Tribunais, 1970

Ensaios e pareceres de direito empresarial. Rio de Janeiro: Forense, 1978. . Direito empresarial: estudos e pareceres, A Reforma da Empresa, $1^{\text {a }}$ ed., São Paulo: Saraiva, 1995. A afirmação histórica dos direitos humanos, $3^{\mathrm{a}}$ ed. ver. e ampl., São Paulo: Saraiva, 2003

CorreA, José Antônio B. L. Faria. A propriedade industrial como direito fundamental - a Constituição de 1988, Revista da Associação Brasileira da Propriedade Intelectual, $\mathrm{n}^{\circ}$ 5, set./out. 1992

Costa, Philomeno J. da. A proteção do nome comercial. Revista de Direito Mercantil, Industrial, Econômico e Financeiro nº 81, jan./ mar. 1.991 Anotação às companhias, São Paulo: Revista dos Tribunais, 1.980 
Costi, Renzo. Il nome della società. Padova, Cedam, 1964.

DE CuPIS, Adriano. Os direitos da personalidade. Tradução de Adriano Vera Jardim e Antônio Miguel Caeiro. Lisboa: Livraria Morais, 1961

Delmanto, Celso. Crimes de concorrência desleal. São Paulo: Butshatski, Ed. da Universidade de São Paulo, 1975

De Mattia, Fábio. Direitos da personalidade. In Limongi FrançA, Rubens (Coord.). Enciclopédia Saraiva de Direito. São Paulo: Saraiva, 1977, v. 25

Di Franco, Luigi. Trattato della Proprietà Industriale, Società Editrice Libraria, Milano, 1.933

DomingueS, Douglas Gabriel. Marcas e expressões de propaganda. Rio de Janeiro: Forense, 1984.

Duval, Hermano. Concorrência desleal, São Paulo: Saraiva, 1976

EsteVES, Luciana Batista. A ICANN e a regulamentação dos nomes de domínio. Revista da ABPI, no 79, nov./dez. 2005

FEKETE, Elisabeth Kasznar. O regime jurídico do segredo de indústria e comércio no direito brasileiro. Rio de Janeiro: Forense, 2003

FerreIRA, Waldemar. Tratado de Direito Comercial, São Paulo: Saraiva, 1962, sexto e sétimo volumes.

Forgioni, Paula A. A interpretação dos negócios empresariais no novo Código Civil Brasileiro, Revista de Direito Mercantil no 130, 2003

FrANÇA, Erasmo Valladão Azevedo e Novaes. Empresa, empresário e estabelecimento. A nova disciplina das sociedades. Revista da Associação dos Advogados de São Paulo, Ano XXIII, agosto de 2003, n 71 
FrANÇA, Rubens Limongi. Do nome civil das pessoas naturais. $2^{\mathrm{a}}$ ed. rev., São Paulo: Revista dos Tribunais, 1964

Direitos da Personalidade - Coordenadas Fundamentais. Revista da Academia Brasileira de Letras Juridicas Rio de Janeiro, v.7, n.4, p.37-50, 1993

FRANCESCHELLI, Remo. Trattato di diritto industriale. Milano, Giuffrè, 1973.

FrAnCO, Vera Helena de Mello. Manual de Direito Comercial, vol. 1: o empresário e seus auxiliares, o estabelecimento empresarial, as sociedade, $2^{\mathrm{a}}$ ed. rev., atual. e ampl., São Paulo: Revista dos Tribunais, 2004

FróES, Carlos Henrique de Carvalho. Nome Comercial III. Enciclopédia Saraiva de Direito, São Paulo: Saraiva, 1977

Gama Cerqueira, João da. Tratado da propriedade industrial. Rio de Janeiro: Forense, 1946 v. 1,1956, v. 3.

Ghiron, Mario. Corso di Diritto Industriale, volume primo, seconda edizione riveduta ed. ampliata, Roma: 1935

GiachetTA, André Zonaro. A proteção do nome empresarial na perspectiva do Código Civil de 2002: natureza jurídica e concorrência. (Dissertação de Mestrado em Direito), São Pauo: FADUSP, 2007.

GrAu-KunTZ, Karin. Do nome das pessoas jurídicas, São Paulo: Malheiros Editores, 1998

HadDOck Lobo, Eugênio R. e Costa NetTo, Francisco. Comentários ao estatuto da OAB e às regras da profissão do advogado. Rio de Janeiro: Editora Rio, 1978

JABUR, Wilson Pinheiro. Nome de domínio: novo sinal distintivo? In Propriedade Intelectual: sinais distintivos e tutela judicial e administrativa, JABUR, Wilson Pinheiro e SANTOS, Manoel J. Pereira dos (Coords.). São Paulo: Saraiva, 2007 
JUnIOR, Humberto Theodoro. Tutela jurisdicional da propriedade industrial. Anais do V Seminário Nacional da Propriedade Intelectual da Associação Brasileira da Propriedade Intelectual, 1.985.

LABRUNIE, Jacques. Conflitos entre nomes de domínio e outros sinais distintivos. In Direito \& Internet: aspectos jurídicos relevantes, Bauru: Edipro, 2000

LADAS, Stephen P. La protection internationale de la propriété industrielle, Paris: E. de Boccard, 1933

LAnge, David, LAFrance, Mary e MYers, Gary. Intellectual Property: cases and materials. St.Paul, Minn.: West Group, 1998

LEÃES, Luiz Gastão Paes de Barros. A disciplina do direito de empresa no novo Código Civil Brasileiro. Revista de Direito Mercantil, Industrial, Econômico e Financeiro. São Paulo, v. 41, n. 128, p. 7-14, out./dez. 2002

LEITE, Augusto. O nome commercial, São Paulo: s.n., 1916

LEITE, Solidonio Attico. Do nome commercial e suas garantias, Rio de Janeiro: Jornal do Commercio, 1919

LeONARDOS, Gabriel Francisco. A proteção jurídica ao nome comercial, ao título de estabelecimento e a insígnia no Brasil. Revista da Associação Brasileira da Propriedade Intelectual, nº 13, nov./dez. 1994.

A proteção ao nome empresarial. In Propriedade Intelectual: sinais distintivos e tutela judicial e administrativa, JABUR, Wilson Pinheiro e SANTOS, Manoel J. Pereira dos (Coords.). São Paulo: Saraiva, 2007.

LEONARDOS, Luiz. A proteção ao nome comercial no Direito Brasileiro, RT 450/25 Apreciação do conflito entre marcas e nomes comerciais. Revista da Associação Brasileira da Propriedade Intelectual, nº 41, jul./ago. 1999 e LEONARdos, Thomás. Nome comercial e marca de indústria e comércio. Revista dos Tribunais, vol. 491 
LeOnARDos, Thomás. Origem, evolucao, natureza e tutela do nome comercial. Rio de Janeiro: Leuzinger, 1934

LOBO, Paulo. Comentários ao estatuto da advocacia e da OAB. São Paulo: Saraiva: 2007

Lotufo, Renan. Curso avançado de Direito Civil, vol. 1, Parte Geral, (coord. Everaldo Augusto Cambler), São Paulo: Revista dos Tribunais, 2002

MaGalHÃES, Descartes Drummond de. Marcas de indústria e de commercio e privilégios de invenção. São Paulo: Zenith, 1925.

MARINONI, Luiz Guilherme. Tutela inibitória. São Paulo: Revista dos Tribunais, 2000.

A proteção possessória às marcas comerciais. Revista de Processo $n^{\circ} 51$, jul./set. 1988

Marca Comercial, direito de invento, direito autoral etc.; Impropriedade do uso das ações possessória, cominatória e cautelar; cabimento da ação inibitória. Revista dos Tribunais, São Paulo, v. 88, nº 768, out. 1999

MARTINS, Fran. Contratos e obrigações comerciais. Rio de Janeiro: Forense, 1981.

Curso de Direito Comercial: empresa comercial, empresários individuais, microempresas, sociedades comerciais, fundo de comércio, $27^{\mathrm{a}}$ ed. rev. e atual., Rio de Janeiro: Forense, 2001

Mathely, Paul. Le Droit Français des Signes Distinctifs, Paris: Librairie du Journal des Notaires et des Avocats, 1984

Mattos Neto, Antonio José de. O empresário à luz do novo Código Civil. Revista da Associação dos Advogados de São Paulo, Ano XXIII, agosto de 2003, nº 71

MendonçA, José Xavier Carvalho de. Trattato de Direito Comercial Brasileiro, Rio de Janeiro: Freitas Bastos, 1957 
MoraES, Walter. Concepção tomista de pessoa. Revista dos Tribunais. São Paulo: ano 73, v. 590,1984

Nery Junior, Nelson et al. Código de Processo Civil comentado e legislação processual civil extravagante em vigor. São Paulo: Revista dos Tribunais, 1997

et al. Novo Código Civil e legislação extravagante anotados. São Paulo: Revista dos Tribunais, 2002

Olavo, Carlos. Propriedade Industrial, vol. I, $2^{\text {a }}$ ed. actual., rev. e aumentada. Coimbra: Almedina, 2005

OLIVEIRA ASCENSÃO, José de. Nome de edifício: conflito com marca, insígnia ou logotipo? In Cadernos de Direito de Marcas. OliveIRA, Maurício Lopes de (Coord.). Rio de Janeiro: Lumen Juris, 2007

PICARD, Edmond. O direito puro, $2^{\text {a }}$ ed., Salvador: Progresso, 1954

PINHEIRO, Waldemar Alvaro. Do conflito entre nome comercial e marca. Revista da Associação Brasileira da Propriedade Intelectual, vol. 31, nov./dez. 1997

PINTo Antunes, José. Da concorrência desleal na legislação brasileira. São Paulo: Revista dos Tribunais, 1940.

Pontes DE MiRAnda, Francisco Cavalcanti. Tratado de direito privado, Parte Especial, $4^{\mathrm{a}}$ ed., São Paulo: Revista dos Tribunais, 1983, t. XVI Tratado de direito privado, Parte Especial, Rio de Janeiro: Borsoi, t. XVII

Pouillet, T. Eugène. Traité des marques de fabrique et de la concurrence déloyale en tous genres. Paris, Marchal \& Godde, 1912.

ProençA, José Marcelo Martins. Direito Comercial 1, 2ª ed. São Paulo: Saraiva, 2008

RAMELla, Augustín. Tratado de la propiedad Industrial. Madrid: Hijos de Reus Ed., 1913. 
REALE, Miguel. Incabíveis restrições administrativas ao livre uso das marcas industriais e mercantis apud Temas de Direito Positivo, São Paulo: Revista dos Tribunais, 1.992 Lições preliminares de direito, 23 a ed., São Paulo: Saraiva, 1996

REQUĩ̃o, Rubens. Curso de Direito Comercial, São Paulo: Saraiva, 1982, $13^{\text {a }}$ ed.

Rotondi, Mario. Diritto Industriale. IV ed., Milão: Casa Editrice Ambrosiana, 1942.

Roubier, Paul. Le Droit de la Propriété Industrielle, Partie Spéciale: Paris: Éditions Du Recueil Sirey, 1952.

RovelLI, Roberto. La concorrenza sleale ed $i$ beni inmateriali di diritto industriale. Torino: UTET, 1967.

SAHM, Regina. Direito à imagem no direito civil contemporâneo: de acordo com o novo código civil, Lei no 10.406, de 10-1-2002, São Paulo: Atlas, 2002

Salomão Filho, Calixto. Direito Concorrencial: as condutas, São Paulo: Malheiros Editores, 2003

SAntagata, Carlo. Concorrenza sleale e interessi protetti. Napoli, Jovene, 1975.

SchMidT, Lélio Denicoli. Princípios Aplicáveis aos Sinais Distintivos. In Propriedade Intelectual: sinais distintivos e tutela judicial e administrativa, JABUR, Wilson Pinheiro e SANTOS, Manoel J. Pereira dos (Coords.). São Paulo: Saraiva, 2007.

SILVEIRA, João Marcos. O nome empresarial no novo Código Civil. Revista da Associação Brasileira da Propriedade Intelectual, nº 61, nov./dez. 2002, e Revista de Direito Mercantil, Industrial, Econômico e Financeiro, nº 128, out./dez. 2002

SILVEIRA, Newton. Curso de Propriedade Industrial. São Paulo: Revista dos Tribunais, 1.977.

Nome Comercial Objetivo e Subjetivo, Revista de Direito Mercantil, Industrial, Econômico e Financeiro no $45,1.982$ 
Licença de uso de marca e outros sinais distintivos. São Paulo: Saraiva, 1984. A propriedade intelectual e a nova lei de propriedade industrial. São Paulo: Saraiva, 1996.

. Estudos e Pareceres de Propriedade Intelectual. Wilson Silveira (Org.), Rio de Janeiro: Lúmen Juris, 1998.

A propriedade intelectual na Internet e a questão dos nomes de domínio, Revista de Direito Mercantil, São Paulo: Revista dos Tribunais, ano 29, n 119, jul./set. 2000.

TAVARES PAes, Paulo Roberto. Propriedade Industrial, São Paulo: Saraiva, 1982

Tinoco SoARes, José Carlos. Nome Comercial, São Paulo : Atlas, 1968.

Comentários ao Código da Propriedade Industrial. São Paulo: Resenha Tributária, 1.981.

. Tratado da Propriedade Industrial. São Paulo: Resenha Tributária, 1.988.

. Lei de patentes, marcas e direitos conexos. São Paulo: Revista dos Tribunais,

1997

. Processo civil nos crimes contra a propriedade industrial. São Paulo: Jurídica Brasileira, 1998.

Marcas vs. Nome Comercial: Conflitos, São Paulo: Jurídica Brasileira, 2000

Abuso de direito pelo uso de nomes de domínio na Internet, São Paulo:

Revista dos Tribunais, ${ }^{\circ}$ 786, p. 68-76, abr. 2001

Novo Código Civil: pessoas jurídicas, empresário, sociedade, estabelecimento, nome comercial e/ou empresarial, perdas e danos e prescrição. Revista da Associação Brasileira da Propriedade Intelectual, $n^{\circ}$ 58, mai./jun. 2.002

Nome comercial versus marca. In Propriedade imaterial: direitos autorais, propriedade industrial e bens de personalidade. Eliane Yachoub Abrão (Org.). São Paulo: Senac, 2006

VAMPRÉ, Spencer. Do nome civil: sua origem e significação sociologica; teorias que explicam; suas alterações; direitos e deveres correlativos, Rio de Janeiro: Brighiet, 1935 Manual de Direito Civil Brasileiro, Rio de Janeiro: Brighiet, 1.920 
VASCONCElos, Justino. Das firmas e denominações comerciais, Rio de Janeiro: Revista Forense, 1.957.

VerçosA, Haroldo Malheiros Duclerc. Curso de Direito Comercial, vol. 1, São Paulo: Malheiros Editores, 2004

VIVANTE, Cesare. Instituições de direito commercial, Lisboa: Livr Classica Ed, 1918.

Watanabe, Kazuo. Código Brasileiro de Defesa do Consumidor Comentado pelos Autores do Anteprojeto, $7^{\mathrm{a}}$ ed. São Paulo: Forense Universitária, 2001. 


\section{RESUMO}

O nome de empresa é um dos mais antigos sinais distintivos do empresário, remontando sua origem ao início do tráfico de mercadorias. Todavia, a proteção ao nome de empresa é problema crônico no Brasil, sendo, desde o século XIX, objeto de intensos e insolúveis debates, especialmente quanto à sua natureza, função, extensão e âmbito territorial de proteção. Assim, o objetivo deste trabalho é a estudar o nome de empresa à luz da hodierna legislação, doutrina e jurisprudência, analisando a problemática existente em relação à sua proteção.

O trabalho é iniciado com noções propedêuticas sobre o nome, traçando a distinção entre o nome no plano pessoal e empresarial, para, então, tratar especificamente do nome de empresa, conceituando-o e definindo suas modalidades, função, natureza jurídica, regras de formação e disciplina jurídica no Brasil, desde o nascimento da proteção até o conflito com outros sinais distintivos do empresário.

Palavras-chave: Direito - nome comercial - empresa - propriedade industrial concorrência desleal 


\begin{abstract}
The tradename is one of the most ancient distinctive sign of the entrepreneur, ascending to the beginning of commerce. Notwithstanding, the tradename's protection in Brazil is a chronic problem. Since the $19^{\text {th }}$ century, the tradename was a center of insolvable discussion about its nature, function and protection's extension.

Therefore, this paper aims to analyze the most significant features of the tradename in Brazil, taking into consideration the current doctrine, legislation and jurisprudence. This study intends to point out the conception of the name, delineating the differences between civil and tradename, as well as the notion of tradename, its species, its two functions, legal nature, standards of formation and, at last, its substantial protection in Brazil.
\end{abstract}

Key-words: commercial - surname - tradename - intellectual property - unfair competition 